MIHICTЕРСТВО ОСВІТИ I НАУКИ УКРАЇНИ

НАЦІОНАЛЬНИЙ УНІВЕРСИТЕТ

«ОДЕСЬКА ЮРИДИЧНА АКАДЕМІЯ»

\title{
ПРАВА ЛЮДИНИ В УКРАЇНІ ТА У ЗАРУБІЖНИХ КРАЇНАХ: ПРОБЛЕМИ ТЕОРІЇ \\ ТА НОРМАТИВНО-ПРАВОВОЇ РЕГЛАМЕНТАЦІЇ
}

Колективна монографія

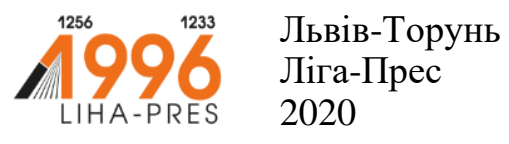


Рекомендовано до друку Вченою радою Національного університету «Одеська юридична академія» (протокол № 7 від 11.05.2020р.)

\section{Рецензенти:}

Крусян А.Р., завідувач кафедри конституційного, адміністративного та міжнародного права Київського інституту інтелектуальної власності та права НУ ОЮА, д.ю.н., професор, Заслужений юрист Украӥни;

єзеров А.А., суддя Верховного Суду, к.ю.н., доцент

Васильченко О.П. - д.ю.н., професор, професор кафедри конституційного права Київського національного університету імені Тараса Шевченка;

Дешко Л.М. - д.ю.н., професор, завідувач кафедри міжнародного публічного права Київського національного торгівельно-економічного університету;

Латковська Т.А. - д.ю.н., професор, завідувач кафедри конституційного, адміністративного та фінансового права Чернівецького юридичного інституту Національного університету «Одеська юридична академія»;

Мішина Н.В. - д.ю.н., професор, професор кафедри конституційного права Національного університету «Одеська юридична академія» (відповідальна за випуск)

Права людини в Україні та у зарубіжних країнах: проблеми теорії П68 та нормативно-правової регламентації : колективна монографія / За заг. ред. Н. В. Мішиної. - Львів-Торунь : Ліга-Прес, 2020. - 392 с.

\section{ISBN 978-966-397-210-7}

Монографія присвячена сучасним трансформаційним процесам у сфері прав людини. Проаналізовано тенденції, що виникають під впливом глобалізації, зміни у співвідношенні національного, міжнародного та наднаціонального рівнів правового регулювання. Значну увагу приділено дослідженню політичних, економічних i соціальних перетворень в Україні та у світі. У виданні досліджується вплив культурологічних та соціально-політичних факторів на розвиток доктринальних підходів і практики правового регулювання, у першу чергу на реалізацію та захист прав людини у сучасному світі.

Для науковців, практичних працівників, викладачів, студентів та широкого кола читачів.

$$
\text { УДК } 342.7(477)+341.231 .14(100)
$$

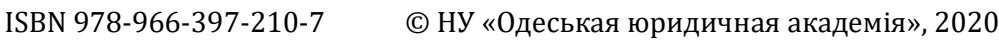




\section{MICT}

Батанов О. В.

Муніципальні права людини в умовах

глобалізації: тенденції становлення

та особливості реалізації.................................................. 5

Васильченко О. П., Матат А. В.

Конституційні права людини:

зміст, функції та рамки обмеження

Волощук О. Т., Колесник В. Ю.

Право на освіту у XXI столітті: поняття,

стандарти та проблеми реалізації.

Головащук А. П.

Репродуктивні права людини як різновид

прав новітніх поколінь: теорія та

нормативно-правова регламентація

Гулиев Арифб Джсамиль оглы

Народная дипломатия как действенный инструмент демократического

развития общества

Денисов В. Н., Фалалєєва Л. Г.

Громадянські права людини крізь призму

відступу України від зобов'язань в умовах

збройного конфлікту та тимчасової окупації

частини її території

Заморська Л. І., Гураленко Н. А.

обмеження прав людини і його

основоположні принципи

Заяць Н. В.

Гідність людини як абсолютна цінність:

філософсько-правове розуміння............................. 185

Козакевич О. М.

Особливості реалізації права на доступ

до правосуддя у транзитивних умовах .................. 208 
Крестовська Н. М., Матвєєва Л. Г.

Особисті права людини першого покоління

в національному, регіональному

та міжнародному вимірі

Лотюк О. С., Митник О. В.

Генезис механізму судового захисту

конституційних прав людини

Любченко М. І., Буряковська К. О.

Сучасний міжнародний правопорядок

у контексті ст. 28 Загальної декларації

прав людини.

Міхальов В. 0.

Конституційні принципи, заборони

і гарантії як елементи правового

становища особистості. 306

Полішук Н. Р.

Право на освіту осіб з особливими освітніми потребами

Timofeyeva L. Yu.

Problems of human rights and their development

in the conditions of a changing society 349

Шевченко А. $\epsilon$., Кудін С. В.

Конституційні засади забезпечення

права людини на здоров'я:

порівняльно-правове дослідження. 
Права людини в Україні та у зарубіжних країнах:

проблеми теорії та нормативно-правової регламентації

DOI https://doi.org/10.36059/978-966-397-210-7/5-44

Батанов О. В.,

доктор юридичних наук, професор,

провідний науковий співробітник відділу

конституційного права та місцевого самоврядування

Інституту держави і права імені В. М. Корецького

Національної академії наук України,

м. Київ

\section{МУНІЦИПАЛЬНІ ПРАВА ЛЮДИНИ В УМОВАХ ГЛОБАЛІЗАЦІЇ: ТЕНДЕНЦІЇ СТАНОВЛЕННЯ ТА ОСОБЛИВОСТІ РЕАЛІЗАЦІЇ}

Анотація. Розділ присвячено дослідженню проблем впливу глобалізації на сучасне муніципальне право та право людини у сфері місцевого самоврядування. Визначено місце місцевого самоврядування та інститутів локальної демократії в окремих європейських державах, європейському континенті загалом та загальноцивілізаційному значенні з погляду прав людини.

Доведено, що стрімкий розвиток муніципального права у сучасних демократіях, тріумфальний рух принципів субсидіарності, регіоналізації та децентралізації, який відбувся у період після другої світової війни в Європі та США, породив тенденцію муніципалізації конституційного життя та правових систем загалом. Свідченням тому $\epsilon$ становлення системи муніципальних прав людини, механізмів їх гарантування та захисту, що $\epsilon$ основою для соціального гомеостазису територіальної громади, який, з одного боку, $\epsilon$ невіддільною характеристикою організації та діяльності місцевого самоврядування на певній території та, з іншого боку, властивістю сучасного муніципального права, яке своєю чергою виконує специфічну гомеостазисну роль у процесах формування соціально-правової державності та громадянського суспільства.

Автор розглядає і аналізує основні положення міжнародноправових актів, що містять європейські правові стандарти 
Права людини в Україні та у зарубіжних країнах:

проблеми теорії та нормативно-правової регламентації

місцевого самоврядування та прав людини, оцінює їх впровадження в украӥнське законодавство. Автор наголошує на необхідності обов'язкового використання європейських правових стандартів у нормотворчості в сфері місцевого самоврядування. Розглядаються сучасні міжнародні договори з погляду їх значення як жерел муніципального права Украӥни.

у процесі дослідження було встановлено, що більшість міжнародних документів розширює діапазон прав жителів членів територіальних громад. Закріплення таких положень на універсальному та регіональному рівні за допомогою рамкових норм міжнародного права свідчить про важливість інституту місцевого самоврядування не тільки у міжнародному аспекті, що характеризується актуалізацією $і$ глобалізацією предметів муніципально-правового

регулювання, але й в національному (внутрішньодержавному) вимірі, ї роллю у процесах формування національного муніципального законодавства, реалізації прав людини, становлення муніципальної влади та ефективної моделі місцевого самоврядування в Україні.

\section{1. Проблеми концептуалізації муніципальних прав людини}

Права людини як найвищий критерій рівня та розвиненості сучасної людської цивілізації виражають найбільш сутнісне у взаємовідносинах як людини з людиною, так і людини зі всіма соціальними спільнотами, в яких вона природним чином перебуває- від сім'ї, народу i нації, соціальної, конфесійної або етнонаціональної належності, професійно-трудової групи, політико-державного об’єднання до людства. У суб'єктивних правах втілені політичні, економічні, соціальні, духовно-ідеологічні, культурні та екологічні основи життєдіяльності людей не тільки в окремих суспільствах та державах, а і в масштабах загальнолюдських.

Права людини сьогодні є однією з ключових проблем, які досліджуються з самих широких та різноманітних позицій з філософсько-гуманістичного погляду, в аспекті сутності 
публічної влади, принципів модернізації політичної та правової системи, проведення соціально-економічної та культурної політики, боротьби з екологічними загрозами, дискримінацією, тероризмом, злочинністю, корупцією тощо. По суті, права людини «відкрили фундаментальну тему про відносини між громадянами та державами» та розкрили «внутрішній конфлікт у міжнародному співтоваристві, який існує між порядком та справедливістю, між суспільством та державою» [1, с. 482].

Так, на думку зарубіжних дослідників, в середині XX ст. в розумінні прав людини «відбулася революція, яка втілила природно-правову доктрину в нормах міжнародного i національного права» [2, с. 261], яка дозволила подивитися на них (права людини - Aвт.), як на «нові стандарти цивілізації» [3]. Без перебільшення, дотримання прав людини вже стало частиною сучасних уявлень про міжнародну легітимність держав. Права людини міцно увійшли до арсеналу правового регулювання всередині держави i не можуть бути проігноровані країнами в їх зовнішній політиці. При цьому «внутрішній порядок реалізації норм про права людини залишається визначальним, а сама тематика цих прав демонструє можливість прогресу в міжнародних відносинах» [4, с. 261-264].

Таким чином, актуалізувалася проблематика прав людини в зв'язку зі здійсненням зовнішніх функцій та конституційноправовим забезпеченням зовнішньополітичної діяльності держави в умовах глобалізації та міждержавної інтеграції, гармонізацією правових систем та формуванням глобального конституціоналізму, а самі права людини стали інструментом, що зближує норми і цінності людства, держав і міжнародного співтовариства.

Водночас слід констатувати, що глобалізаційні процеси у сфері прав людини значною мірою детермінували визнання наприкінці XX - початку XXI ст. ст. на міжнародному рівні місцевого самоврядування як основи будь-якого демократичного ладу, що, з одного боку, значною мірою посилило тенденцію глобалізації доктрини місцевого 
самоврядування та муніципального права, яка особливо рельєфно спостерігається у сучасних євроінтеграційних процесах, та, з іншого боку, вкотре засвідчило той факт, що більшість прав людини реалізується та переважною мірою захищається на локальному рівні, переконливо підтверджуючи вірність одного з девізів Дня Землі - «Мисли глобально, дій локально!».

Вважаємо, що найбільш рельєфно проявляється та знаходить свою апробацію ідея цінності людської особистості, її суб’єктивних прав на локальному рівні - у межах місцевого самоврядування та процесах інституціоналізації муніципальної влади. Адже визнання та становлення місцевого самоврядування, глибокі економічні і політичні перетворення у суспільстві і формування на цій основі нової демократичної державності безпосередньо пов'язані 3 виробленням і практичною реалізацією принципово нових підходів до прав людини, вирішення як загальнодержавних, так і регіональних, а також місцевих проблем у цій сфері.

Саме місцеве самоврядування має створити умови для формування у людському співтоваристві відчуття громадянськості - однієї з тих базових, наріжних рис суспільства, які знаходяться у фундаменті соціуму. Громадянськість - це готовність і здатність людини до активної участі у справах суспільства і держави на основі глибокого усвідомлення своїх прав та обов'язків. Вона $€$ антитезою таких понять, як аполітичність, абсентеїзм, соціально-політична індиферентність, та синонімом соціально-політичної активності, патріотизму. Громадянськість історично пов'язана з ранніми формами демократії, зокрема 3 безпосередньою участю у справах громади і зародженням суспільних відносин полісного типу [5, с.647]. За своєю суттю громадянськість означає ступінь кооперації людей в одне ціле, ступінь відходу від біологічних потреб та руху до потреб соціальних, ступінь спільності, єдності людей. Громадянськість консолідує суспільство, вона знаходиться в основі колективізму, детермінуючи цілісність та монолітність суспільних 
утворень. Громадянськість у її найбільш розвинутій формі передбачає розвиток таких цінностей, як права та свободи, мир та справедливість, відповідальність та соціальна рівність. А це - ключові цінності розвинутого демократичного та громадянського суспільства [6, с. 3].

У цьому аспекті місцеве самоврядування тим самим відіграє вагому роль у процесі формування громадянського суспільства, враховуючи, що усі права, свободи та колективні види соціально-політичної, господарсько-економічної та духовно-культурної активності, різні недержавні прояви суспільного життя людей зароджуються та у кінцевому рахунку реалізуються у територіальних громадах, які утворюють соціальну базу громадянського суспільства.

Протягом тривалої історії свого існування люди прагнули проаналізувати сутність феномена громадянськості та виявити ті чинники, які можна використати як важелі впливу на процеси іï формування та функціонування. На наш погляд, одним із визначальних інструментів формування та функціонування громадянськості $€$ інститут повноцінного місцевого самоврядування. Саме місцеве самоврядування оптимально фіксує у собі як елементарні проблеми людської життєдіяльності, так і політичні, економічні, духовноморальні цінності та соціальні досягнення людства у будьякій галузі суспільного розвитку. Через це відносно невеликі територіальні розміри територіальних громад, локальність діяльності їх органів, здебільшого безпосередній характер взаємовідносин жителів між собою та з органами місцевого самоврядування, природний характер проблем життєдіяльності - усе це в цілому обумовлює особливу муніципальну соціальність. Адже народження людини, іï здоров'я, дорослішання, навчання, працевлаштування, шлюб та сім'я, старіння, смерть - у рамках цих життєвих циклів в основному замикається життєдіяльність місцевого співтовариства.

Також на цьому рівні реалізації публічної влади відбувається діалектичне поєднання волі законодавця 3 конкретними інтересами місцевого населення, яке стає не лише первинним суб'єктом локальних конституційно- 
правових відносин, а й основним суб'єктом управлінських, адміністративно-правових відносин, а також приватних, цивільно-правових відносин, що $є$ однією з характерних рис місцевого самоврядування. У зв'язку з цим варто підтримати позицію, за якою єдиним шляхом здійснення людиною публічної діяльності у рамках будь-якого співтовариства (за обов'язковості нормативного регулювання подібної поведінки) $\epsilon$ реалізація наявних у неї прав та свобод. Через сукупність суб'єктивних прав та свобод можна розглянути весь спектр відносин, що виникають у процесі спільної діяльності людей [7, с. 15].

У зв'язку з цим дослідження прав людини у контексті місцевого самоврядування та конституційно-правових проблем організації та функціонування муніципальної влади, так само як і концептуалізація місцевого самоврядування через призму прав людини та реалізації принципу правовладності, який передбачає панування права у суспільстві та вимагає від держави його втілення у правотворчу та правозастосовну діяльність, зокрема у закони, які за своїм змістом мають бути проникнуті передусім ідеями соціальної справедливості, свободи, рівності тощо, $\epsilon$ одним з найважливіших завдань юридичної науки. Це має не тільки науково-теоретичне значення, а й насамперед практичну значущість: і з погляду розвитку законодавства, і в плані вирішення конкретних питань формування реального місцевого самоврядування та становлення дієздатних територіальних громад, утворення ефективних механізмів забезпечення прав людини.

Слід зазначити, що муніципальні права людини мають відносно самостійне значення як категорія сучасного конституціоналізму, нормативно-правовий інститут місцевого самоврядування, важливий інститут муніципальної демократії та неодмінний атрибут муніципальної влади, який одержує у цій якості конституційне визнання. Адже згідно з Конституцією в Україні визнається та гарантується місцеве самоврядування (ст.7) як право територіальної громади - 
жителів села чи добровільного об’єднання у сільську громаду жителів кількох сіл, селища та міста - самостійно вирішувати питання місцевого значення в межах Конституції і законів України (ч. 1 ст. 140). Причому своє право на участь у місцевому самоврядуванні громадяни України реалізують саме за належністю до відповідних територіальних громад.

Правовий статус людини у системі місцевого самоврядування характеризується органічною єдністю індивідуальних муніципальних суб’єктивних прав, котрі належать кожному жителю окремо і можуть бути реалізовані окремим жителем - членом територіальної громади незалежно від інших ії членів та колективних муніципальних прав, реалізація яких можлива лише за допомогою колективних дій усіх чи більшості жителів - членів територіальної громади. За допомогою цього забезпечується, з одного боку, людиноцентристська орієнтація місцевого самоврядування, а 3 іншого - інтеграція автономних, індивідуалістичних начал муніципальної свободи 3 принципами колективізму, общинності на місцевому рівні організації політичного, господарсько-економічного та соціально-культурного життя [8].

Як своєрідний сплав колективізму й автономності особи, муніципальні права складають у цьому плані важливий елемент нормативного змісту всієї системи місцевого самоврядування, завдяки чому конституційні інститути муніципальної демократії отримують чітку орієнтацію не на адміністративно-державні, а на громадські структури, на пріоритет безпосередніх форм колективної участі жителів у вирішенні питань місцевого значення. А самі інститути місцевого самоврядування в їхньому нормативно-правовому закріпленні просто неможливо розглядати у відриві від муніципальних прав та свобод, які втілюють у собі суб'єктивні фактори функціонування цих інститутів як засобу реалізації кожним окремим жителем - членом територіальної громади своїх індивідуальних можливостей брати участь у вирішенні питань місцевого значення [9, с. 308-309]. 
Така характеристика муніципальних прав людини як інституту місцевого самоврядування та основи легітимності муніципальної влади означає, що нормативно-правове забезпечення муніципальних прав здійснюється (має здійснюватися) не тільки на загальнодержавному, а і на всіх рівнях муніципально-правового регулювання, насамперед локальному (муніципальному). Причому в останньому разі суб'єктивні права жителів - членів територіальних громад повинні закріплюватися не шляхом дублювання відповідних конституційних положень, а у напрямі їхньої конституційної конкретизації, розширення, враховуючи, що перелік конституційних прав та свобод не $\epsilon$ вичерпним. Це може виявлятися, по-перше, у формі конкретизації всіх чи окремих правомочностей, що мають конституційно-правове визнання як права людини; по-друге, встановленням процедури, порядку реалізації відповідного права на певній території; по-третє, закріпленням специфічних муніципальних гарантій здійснення конкретних суб'єктивних прав людини у територіальних громадах.

\section{2. Муніципальні права людини у контексті міжнародних стандартів місцевого самоврядування}

Світовий досвід свідчить, що становлення системи муніципальних прав людини, механізмів їх гарантування та захисту $\epsilon$ основою для соціального гомеостазису територіальної громади, який, з одного боку, є невіддільною характеристикою організації та діяльності місцевого самоврядування на певній території та, з іншого боку, властивістю сучасного муніципального права, яке своєю чергою виконує специфічну гомеостазисну роль у процесах формування соціально-правової державності та громадянського суспільства [10, с. 4].

Місцеве самоврядування, регіоналізація та децентралізація стають тепер провідними принципами демократичної внутрішньої та зовнішньої державної політики та конституційно-правового регулювання у розвинутих країнах. 
У світі все більше відбувається усвідомлення того, що надмірний централізм не змінює держави, а веде до нездатності державного апарату та фактичної девальвації конституційних норм. Так, основна спрямованість принципу субсидіарності у XX ст. полягала у подоланні фашистських і соціалістичних тенденцій, захисті автономії особи та права на самоврядування низових політичних одиниць територіальних громад.

Субсидіарність організації влади тим самим протиставлялася тенденціям у напрямі авторитарної централізованої держави. Субсидіарність розглядалася як передумова устрою, що базується на свободі: держава, яка дотримується принципу субсидіарності, гарантує своїм громадянам свободу і незалежність; вона гарантує місцеве і регіональне самоврядування. Захист свободи через реалізацію принципу субсидіарності нині проголошується однією з традиційних цінностей європейського політичного устрою. 3 одного боку, визнання та гарантування широкого каталогу прав територіальних колективів у демократичних країнах створює умови для формування в них моделі так званої «муніципальної держави», а, з іншого - розвинуте місцеве самоврядування бачиться як «запускаючий інструмент» процесу євроінтеграції, транскордонного та міжконтинентального співробітництва.

Так, наприклад, у Рекомендації Конгресу місцевих i регіональних влад Європи 280 (2010) про роль місцевих і регіональних органів влади в дотриманні прав людини від 19 жовтня 2011 року [11] зазначається, що демократія і права людини є взаємозалежними, причому демократія, в тому числі на місцевому та регіональному рівні, не може існувати без безумовного дотримання прав людини. Уцьому ж документі закріплено, що, по-перше, місцеві і регіональні органи влади повинні виконувати ті обов'язки, пов'язані 3 правами людини, які випливають з міжнародних зобов'язань держав-членів, при цьому тільки в рамках своїх місцевих / регіональних повноважень; по-друге, місцеві та регіональні органи влади $\epsilon$ не тільки представниками центрального 
уряду - вони забезпечують права людини одночасно з тим, як вони здійснюють місцеве самоврядування; по-третє, ефективне управління є таким управлінням, яке засноване на дотриманні прав, при цьому виконання обов'язків, пов'язаних 3 правами людини, $\epsilon$ тим викликом, подолання якого може зміцнити демократію на місцевому рівні; по-четверте, необхідно забезпечувати, щоб місцевим i регіональним органам влади виділялися такі фінансові ресурси, рівень яких дозволить цим органам влади належним чином дотримуватися прав людини і при цьому розглядати i розвивати свою власну діяльність для дотримання цих прав; по-п'яте, необхідно залучати представників місцевих i регіональних органів влади до підготовки національних стратегій, політики та індикаторів у галузі прав людини для того, щоб використовувати їх внесок і прагнути усвідомлення ними відповідальності щодо дотримання прав людини; пошосте, необхідно заохочувати місцеві і регіональні органи влади до того, щоб сприяти дотриманню прав людини через ініціативи просвітницького характеру, а також завдяки здійсненню місцевих і регіональних планів дій; по-сьоме, необхідно сприяти створенню незалежних механізмів розгляду скарг на місцевому та регіональному рівні i, зокрема, створювати незалежні органи, такі як місцеві чи регіональні омбудсмени або уповноважені, здатні знайти відповіді в тих випадках, коли права людини повною мірою не дотримуються, зокрема, під час надання публічних послуг на місцевому рівні тощо. У цих Рекомендаціях Конгрес особливо наголошує, що найважливіше значення для поліпшення становища в галузі прав людини в Європі на всіх рівнях має освіта і прийняття відповідних стандартів. Зокрема, рекомендується заохочення систематичного багатоступеневого діалогу між політичними рівнями всіх держав - членів Ради Європи для того, щоб посилювати правозахисний вимір у сфері місцевого самоврядування, а також посилення поваги до прав людини завдяки професійній підготовці місцевих і регіональних виборних представників і їх співробітників. 
В аспекті формування сучасної доктрини муніципального гуманітарного права колосальне значення мають принципи Декларації щодо забезпечення доброго врядування на місцевому і регіональному рівнях 2005 р. [12, с. 11], 3-поміж яких найважливішим $\epsilon$ принцип інноваційності та відкритості до змін, який дозволятиме територіальним громадам знаходити ефективні шляхи вирішення проблем та використовувати сучасні методи надання послуг, реалізовувати пілотні та випробовувати нові програми і вивчати досвід інших, створювати сприятливий клімат для змін задля досягнення кращих результатів.

Мегатрендом сучасного європейського муніципалізму $є$ принцип сталого розвитку та стратегічної орієнтації, який передбачає врахування інтересів майбутніх поколінь. Потреби майбутніх поколінь беруться до уваги в поточній діяльності місцевого самоврядування. Рішення на місцевому рівні мають прийматися з урахуванням усіх видів витрат, якот екологічні, структурні, фінансові, економічні чи соціальні, з метою запобігання передачі проблем та напруги наступним поколінням. Має існувати розгорнуте та стратегічне бачення майбутнього місцевої громади 3 розумінням того, що $\epsilon$ необхідним для такого розвитку.

Як зазначається у Декларації, ефективна демократія та добре врядування на місцевому і регіональному рівнях $\epsilon$ важливими для забезпечення високого рівня надання послуг населенню та, як наслідок, створення громад «сталого розвитку». Такі громади - це території, де люди бажають жити і працювати як сьогодні, так і в майбутньому. Вони відповідають різноманітним вимогам існуючих та потенційних резидентів, здійснюють охорону природного середовища та роблять відповідний внесок у підвищення якості життя громадян. Ці громади $\epsilon$ безпечними та самодостатніми. Вони забезпечують високий рівень якості послуг, які надаються громадянам.

У цьому контексті особливе звучання має рішення учасників цієї Декларації вважати «забезпечення доброго місцевого і регіонального врядування» глобальним 
завданням, яке має бути досягнуто країнами - членами Ради Європи з метою реагування на виклики, які постали перед європейським співтовариством, та забезпечення законних інтересів громадян.

Ці тенденції значною мірою детерміновані особливістю місцевого самоврядування та муніципальної демократії як відкритої та самостійної системи, яка породжена громадянським суспільством та пов'язана з його політичною системою мережею безкінечних прямих та зворотних зв'язків. Місцеве самоврядування $\epsilon$ органічною частиною оточуючого середовища та втілює у собі всю його багатогранність. Його еволюція - це тривалий, розтягнутий у часі та просторі процес, який складається із сукупності історичних етапів, критеріями виділення яких зазвичай $\epsilon$ різкі, переломні моменти у розвитку суспільства і держави, демократії та владних інститутів, які були викликані сукупністю загально цивілізаційних, державних та регіональних, внутрішніх та зовнішніх, політичних, економічних, соціальних, культурних, екологічних та інших тенденцій і процесів, які детермінують можливість виникнення, визнання та розвитку місцевого самоврядування у конкретній державі.

Саме місцеве самоврядування оптимально фіксує у собі як елементарні проблеми людської життєдіяльності, так і політичні, господарсько-економічні, соціально-культурні, духовно-моральні цінності та соціальні досягнення людства у будь-якій галузі суспільного розвитку. Через це відносно невеликі територіальні розміри територіальних громад, локальність діяльності їх органів, здебільшого безпосередній характер взаємовідносин жителів між собою та з органами місцевого самоврядування, природний характер проблем життєдіяльності - усе це загалом зумовлює особливу муніципальну соціальність. Адже у рамках таких життєвих циклів, як народження людини, іï здоров'я, дорослішання, навчання, працевлаштування, шлюб та сім'я, старіння, смерть, замикається життєдіяльність місцевого співтовариства. 
Через це сьогодні особливо актуалізується питання про процеси визнання, становлення та перманентного розвитку муніципалізму, місцевого самоврядування та інститутів локальної демократії в окремих європейських державах, європейському континенті загалом та загальноцивілізаційному значенні як з погляду формування українського, європейського та світового конституціоналізму, процесів демократизації, глобалізації та європейської міждержавної інтеграції, так і з погляду формування сучасної ефективної моделі міжнародного гуманітарного права, конституційного гуманітарного права та муніципального гуманітарного права. Саме у цьому аспекті й варто розуміти зафіксований у преамбулі Європейської Хартії місцевого самоврядування [13] мотив їі прийняття: «охорона i посилення місцевого самоврядування в різних країнах Європи є важливим внеском у розбудову Європи на принципах демократії $\mathrm{i}$ децентралізації влади».

Фундаментальні принципи демократії, верховенства прав людини, визнання місцевого самоврядування, а також акумульований світовий досвід організації та функціонування муніципальної влади, знайшли своє закріплення у так званих міжнародно-правових стандартах місцевого самоврядування, які відіграють колосальну роль у процесах формування європейського муніципального права, нормативному регулюванні організації та функціонуванні місцевого самоврядування, як в окремих зарубіжних країнах, так і на регіональному і глобальному рівнях, а також становлення багаторівневої системи захисту прав людини, у тому числі муніципального правозахисного механізму.

у практиці муніципального будівництва найбільш важливим $\epsilon$ не тільки загальне визнання, рецепція, ратифікація, імплементація та законодавче закріплення стандартів місцевого самоврядування, але й реальний та ефективний режим їх дотримання та захисту. Саме для того щоб муніципальні права людини не залишалися декларативними, необхідний конкретний внутрішньодержавний механізм здійснення міжнародних стандартів 
місцевого самоврядування. Формування такого механізму, налагодження його елементів залишається однією 3 найбільш актуальних проблем удосконалення муніципального законодавства.

Міжнародні стандарти муніципальної демократії відіграють значну роль у процесах становлення муніципалізму, соціально-правової державності та реалізації прав місцевого самоврядування в сучасному світі. Такими стандартами $\epsilon$ міжнародно-правові норми, що регламентують основні принципи, форми і методи здійснення муніципальної діяльності, прийняті державами світу в рамках міжнародних міждержавних організацій. Особливостями міжнародних стандартів у цій сфері $\epsilon$ те, що вони регламентують спільно вироблені державами концептуальні підходи і міжнародно-легальні принципи становлення, формування i функціонування інституту місцевого самоврядування на території конкретних держав.

Закріплення таких положень на універсальному та регіональному рівні за допомогою рамкових норм міжнародного права свідчить про важливість інституту місцевого самоврядування не тільки у міжнародному аспекті, що характеризується актуалізацією і глобалізацією предметів муніципально-правового регулювання, але й у національному (внутрішньодержавному) вимірі, їх роллю у процесах формування національного муніципального законодавства, реалізації прав людини, становлення муніципальної влади та ефективної моделі місцевого самоврядування в Україні.

У сучасних міжнародно-правових стандартах локальної демократії доволі рельєфно відображене ії значення в умовах глобалізації та міждержавної інтеграції, зокрема, безпосередньо зазначається, що міждержавні угоди, які укладаються у сфері місцевого самоврядування, прямо зумовлені прагненням до досягнення «більш сильної єдності» між державами (Преамбула Європейської Хартії місцевого самоврядування [13]); стверджується, що вони приймаються зі спеціальною метою - «бути для всіх націй стандартом, до 
якого слід прагнути, намагаючись досягти більш демократичного процесу, поліпшуючи, таким чином, добробут свого населення» (Преамбула Всесвітньої Декларації місцевого самоврядування [14]) або зазначається, що метою їх ухвалення $\epsilon$ «сприяння економічному та соціальному прогресу прикордонних регіонів і зміцненню солідарності, яка об'єднує народи Європи» (Преамбула Європейської рамкової конвенції про транскордонне співробітництво між територіальними общинами або властями [15]).

У преамбулі Декларації щодо забезпечення доброго врядування на місцевому і регіональному рівнях [12, с.11] зазначається, що «завдання, які сьогодні постали перед Європою, не $є$ завданнями виключно для європейських країн - вони $\epsilon$ глобальними та мають паралельно вирішуватись як на міжнародному, так і на місцевому рівнях».

Преамбула проекту Всесвітньої хартії місцевого самоврядування [14] взагалі починається з нагадування, що згідно з принципом, який закріплений у Загальній декларації прав людини, а саме в іï статті 21, воля народу має бути основою влади органів управління всіх рівнів, а місцева демократія $\epsilon$ основоположним правом.

Враховуючи, що «місцеве самоврядування $\epsilon$ необхідним елементом демократичної організації державного та суспільного життя кожної держави - учасниці СНД» та «усвідомлюючи необхідність спільних зусиль усіх держав учасниць СНД у підтримку реалізації демократичних принципів місцевого самоврядування та створення його дієвих гарантій», було прийнято і Декларацію про принципи місцевого самоврядування у державах - учасницях СНД [16].

Такого роду гуманістична спрямованість місцевого самоврядування та його людиновимірний характер вказує на колосальне значення муніципальної демократії в умовах глобалізації, як з погляду вирішення питань місцевого значення, так і з погляду реалізації прав людини. 
Права людини в Україні та у зарубіжних країнах:

проблеми теорії та нормативно-правової регламентації

\section{3. Концептуальні засади та прикладні проблеми реалізації муніципальних прав людини}

Говорячи про конкретний вплив інститутів муніципального права та муніципальної влади на розвиток та реалізацію окремих видів прав людини, необхідно диференційовано підходити до окремих їхніх груп, аналізу нормативного змісту i функціональних зв'язків 3 інститутами місцевого самоврядування та муніципальної демократії. Не ставлячи за завдання вивести якісь нові класифікаційні варіанти аналізу прав та свобод, у тому числі в зв'язку з їхнім впливом на розвиток місцевого самоврядування, спробуємо розглянути особливості реалізації окремих видів муніципальних прав людини виходячи з із їх суб'єктно-об'єктної характеристики, насамперед, з одного боку, в аспекті ролі та значення у процесах функціонування місцевого самоврядування окремих категорій жителів - членів територіальних громад, та, 3 іншого боку, об’єктів місцевого значення та сфер життєдіяльності муніципальних спільнот (політичної, економічної, соціальної, культурної та інших), в межах яких проходить життя людини, реалізуються суб'єктивні потреби та інтереси, що зумовлюють характерні муніципальноправові відносини тощо. Відповідно, виділяючи окремі види та групи муніципальних прав людини, відзначимо найбільш істотні взаємозв'язки цих прав 3 інститутами місцевого самоврядування.

Прикладом тому є положення Стамбульської декларації з проблем поселень людей [17], де, стосовно до конституційного права на безпечне для життя і здоров'я довкілля йдеться про його муніципально-правову модифікацію в обов'язок держав-учасників цього документу забезпечити «особливі потреби жінок, дітей та молоді у надійних, здорових і безпечних умовах життя». 3 цією метою, держави-учасниці цього документу взяли на себе зобов'язання «добиватися покращення умов життя в населених пунктах такими засобами, які відповідають місцевим потребам та реальностям», а також визнали 
«необхідність аналізу глобальних економічних, соціальних та екологічних тенденцій в цілях утворення більш досконалого середовища мешкання для всіх людей». Також державиучасники зобов'язуються «сприяти наданню повноцінного доступу людям 3 фізичними вадами, а також статевого рівноправ'я для участі в політичних акціях, програмах та проектах 3 питань житла та життєздатного розвитку поселень людей» (п. 7).

Про важливість місцевого самоврядування та муніципального права в умовах глобалізації та міждержавної інтеграції свідчать положення Екологічної Угоди Міст від 5 червня 2005 року [18]. Розглядаючи даний документ як «синергетичне продовження зусиль по сприянню стабільності розвитку, посиленню нестійких економік, підвищенню суспільної активності, і захисту природних систем планети», сторони - мери багатьох великих міст світу (у т. ч. і м. Києва), які підписали його, виходили, у першу чергу, 3 того, що «більшість населення планети зараз живе в містах і що безперервна урбанізація приведе до того, що один мільйон людей буде переміщуватись до міст кожного тижня, створюючи тим самим нову низку екологічних проблем i можливостей». Вказуючи на те, що мери міст зі всього світу мають «унікальну можливість керувати розвитком належним чином підтримуваних міських центрів, в основі чого лежатимуть відповідні культурні і економічні місцеві заходи», сторони, які підписали цей документ, «зібралися разом для того, щоб вписати новий розділ в історію всесвітньої кооперації» та взяли на себе «зобов'язання підвищити рівень партнерських стосунків і побудувати екологічно стабільне, економічно динамічне, і соціально справедливе майбутнє для наших міських жителів».

Доволі рельєфно ілюструє проблему реалізації права на участь у місцевому самоврядуванні в умовах глобалізації екстраполяція на локальний рівень загальновизнаного у сучасному світі принципу рівності чоловіка та жінки. Досягнення гендерної рівності неможливе без наявності відповідного механізму реалізації прав і свобод, а зміни в 
Права людини в Україні та у зарубіжних країнах:

проблеми теорії та нормативно-правової регламентації

суспільстві, звичайно, відбуваються через політичний процес, монопольними власниками якого все ще залишаються переважно чоловіки. Втім зміни у суспільстві, у тому числі й у їх гендерному вимірі, можуть відбутися лише за умовою, якщо такі зміни відбудуться у територіальних громадах. У сучасному міжнародному політичному й соціологічному дискурсі поняття місцевого самоврядування, децентралізації та функціонування територіальних громад досить часто розглядають у зв'язку з поняттям гендеру [19]. При цьому увага акцентується на тому, що «впровадження гендеру» означає не просто додавання «жіночого компоненту» до проектів та програм. Це, насамперед, аналіз і врахування різних умов та вимог щодо жінок і чоловіків, тих ролей, які вони відіграють у соціумі в цілому, та територіальних громадах і процесах децентралізації публічної влади, зокрема. Однією з найбільш гендерно-чутливих проблем, характерних для сучасної України, є обмежений їх доступ жінок до влади в цілому та муніципальної влади, зокрема. Адже, незважаючи на те, що жінки в Україні де-юре мають рівні права 3 чоловіками, де-факто вони продовжують зазнавати дискримінації, зокрема і в політичній сфері, оскільки недостатньо представлені на рівні прийняття політичних рішень [20, с. 18-19]. Щоправда, на відміну від національного рівня, ситуація 3 представленістю жіночого досвіду на місцевому рівні $\epsilon$ дещо кращою та такою, що має позитивну тенденцію [21]. Комітет виборців України проаналізував результати виборів до міських рад м. Києва та міст-обласних центрів. За даними з 22 міських рад, обрано 214 депутаток та 969 депутатів. Таким чином, середній рівень представництва жінок в міських радах - 18,1\%. 3214 депутаток, обраних за результатами виборів, 13 (або 6,1\%) були лідерами партійних списків. Для порівняння, серед 5552 жінок-кандидаток в міські ради, було 58 лідерів списків, тобто 1\%. 3 одного боку, це свідчить про те, що закріплення за жінками місць в прохідній частині списку сприяє проходженню в місцеві ради. 3 іншого боку, 93,9\% обраних жінок-депутаток отримали мандат завдяки підтримці виборців, а не закріпленому місцю 
в списку. Тобто в суспільстві $є$ потенціал для підтримки жінок на обрані посади, навіть за умови відносно меншого за чоловіків-кандидатів ресурсного забезпечення агітації. В цілому, зазначають експерти, в порівнянні зі складом міських рад попереднього скликання, ситуація з гендерним балансом покращилась в 11 з 22 радах. Поріг в 30\% було подолано тільки в одній міській раді - а саме, в Чернігівській. При цьому, робиться висновок, що низький рівень представництва жінок в місцевих органах влади, що обираються, не пов'язаний із небажанням жінок йти в політику.

Цікавими та доволі показовими у гендерному вимірі місцевого самоврядування $\epsilon$ й інші висновки [22]. Так, оскільки діяльність місцевої влади базується на традиційно жіночих інтересах: добробут, освіта, чистота довкілля, охорона здоров'я та дозвілля, то й до відповідних структур жінок задіяли нарівні 3 чоловіками. 3 боку гендерної перспективи, органи місцевого самоврядування - це найбільш наближений та доступний рівень управління для жінок. Це пояснює той факт, що відсоток жінок у радах місцевого рівня сьогодні набагато вищий, ніж у Верховній Раді. Це підтверджують і відповідні статистичні дані, які свідчать, що чим нижчий рівень органів влади, тим вони доступніші для жінок.

У цьому аспекті доволі цікавим та ілюстративним $\epsilon$ зарубіжний досвід. Так, згідно з даними організації «Об’єднані міста і місцеві уряди» (UCLG) у світі лише 5\% жінок-мерів та 20\% жінок-депутатів. Лише 10 зі 195 світових столиць очолюють жінки, що складає 5,1\%. Трошки вищим $\epsilon$ рівень представництва жінок-мерів у містах-мільйонниках 29 жінок з 493 мерів міст, що складає 6,1\%. За даними Спілки асоціацій місцевих органів влади південно-східної Європи (NALAS), яка включає в себе 14 повних членів національних асоціацій МСB, 7 - асоційованих членів, 9000 - органів місцевої влади, які представляють 80 млн мешканців, лише 8,4 \% міських голів в південносхідній Європі - це жінки, 91,6\% - чоловіки; 29,9\% 
депутатів в південно-східній Європі - це жінки, 70,1\% - це чоловіки. Стурбовані цією ситуацією на Генеральній асамблеї Спілки асоціацій місцевих органів влади південносхідної Європи (Пріштіна, Сербія 14-15 квітня 2016 р.) делегати спілки прийняли Положення про сприяння гендерній рівності на місцевому рівні [23].

$€$ й інші приклади посиленої уваги світового співтовариства до проблем гендерної рівності у територіальних громадах. Так, країни-учасники Декларації про міста та інші населені пункти в новому тисячолітті [24], вважаючи за необхідне за допомогою відповідних механізмів забезпечити щоб жінки відігравали ефективну роль у прийнятті рішень місцевими органами влади (п. 39), заявили про свою дотриманість меті забезпечення гендерної рівності у розвитку населених пунктів та сповнені рішучості підтримувати гендерну рівність та розширення можливостей жінок у якості ефективних способів боротьби з бідністю та стимулювання розвитку населених пунктів, які будуть по справжньому стійкими. «Ми далі беремо на себе зобов'язання формулювати та зміцнювати політику та практику забезпечення повної та рівноправної участі жінок у плануванні населених пунктів та прийнятті рішень», - зазначалося у Декларації (п. 44).

У гендерному вимірі існування та перспективного розвитку місцевого самоврядування з позиції міжнародних муніципальних стандартів колосальне значення набувають положення Всесвітньої декларації Міжнародного союзу місцевих органів влади про роль жінки у місцевому самоврядуванні [25]. Так, у частині 10 цього документу закріплено, що система місцевого управління займає унікальне положення з точки зору сприяння боротьбі за гендерну рівність на глобальному рівні та може зробити серйозний вплив на положення жінок та ситуація в галузі гендерної рівності в усьому світі; представляє собою рівень керівництва, найбільш близький до громадян, діючи у якості надання послуг та працедавця. У частині 12 документу вказується й наступний мотив розробки цього 
документу: «з метою утворення стійких, заснованих на принципах рівноправ'я та демократії місцевих органів управління, де б жінки і чоловіки мали рівний доступ до процесу прийняття рішень, рівний доступ до послуг i рівний статус в процесі надання цих послуг, гендерна проблематика має бути включеною у всі сфери директивної й управлінської діяльності місцевих органів управління».

Група спеціалістів з гендерного підходу Ради Європи (1995-1998) [26] визначила гендерний підхід як «(ре)організацію, покращення, розвиток та оцінка політичних процесів таким чином, аби аспект гендерної рівності та перспективи був врахований в усіх напрямках політики та на усіх рівнях та етапах при залученні усіх сторін в процесі розвитку політики». Рекомендація 148(2004) Конгресу про гендерний підхід на місцевому та регіональному рівнях наголошує на важливості механізмів гендерної рівності як визнаної системи підтримки, спрямованої допомогти тим особам, яких залучено до розробки політики й надання послуг, зрозуміти й реалізувати концепцію гендерної рівності, а також спосіб, у який належить відстежувати прогрес та заохочувати до звітності осіб, залучених до робіт [27].

Разом з Рекомендацією 148(2004), Резолюція 176(2004) Конгресу закликає органи місцевих та регіональних влад підтримувати гендерну рівність на гендерний підхід та застосовувати в цьому напрямку на практиці відповідні інструменти та механізми, особливо статистику 3 розподілом за статтю [28].

Також, у сучасній Європі одним 3 ефективних інструментів гендерного підходу $\epsilon$ гендерно чутливе бюджетування. Так, Резолюція 405(2016) Конгресу щодо гендерно чутливого бюджетування [29] стимулює національні, регіональні та місцеві органи влади пропонувати та впроваджувати відповідні інструменти та процедури. Особливо ця резолюція наголошує на проведенні місцевими та регіональними органами влади 
аналізу бюджету з розбиттям за статтю, обміні думками та кращими практиками с містами та регіонами, які вже застосовують методи гендерно чутливого бюджетування та планувати механізми консультування та залучення громадського суспільства.

Знаковою є Резолюція 391(2915) Конгресу про боротьбу із зростаючою бідністю серед жінок: відповідальність місцевих та регіональних органів влади [30], яка спонукає країни-члени враховувати гендерний аспект бідності та брати до уваги зростаючий рівень бідності серед жінок в процесі боротьби з бідністю.

Можна згадати й Європейську хартію рівності жінок і чоловіків на місцевому рівні [31], розроблену у 2006 році Радою європейських муніципалітетів і регіонів (CEMR). Європейська хартія, як інструмент політичної волі, дуже корисна для органів місцевого самоврядування. Підписана міськими головами, ця Хартія надає чіткі рекомендації органам місцевого самоврядування щодо заходів в рамках їх компетенції, які потрібно в проваджувати для забезпечення рівноправ'я між чоловіками та жінками (а також національними меншинами, недієздатними особами тощо). Крім сприяння гендерній рівності та рівним можливостям (кампанії, громадський простір, застереження), у документі також зосереджено увагу на важливості виконання гендерного аналізу місцевих рішень/політики, консультацій з чоловіками та жінками стосовно різних питань, а також розвитку гендерно чутливих соціальних служб. Згідно з цим документом, органи місцевого самоврядування зобов'язані розробити план заходів з впровадження політики гендерної рівності а також заохочуються до розробки та обміну кращими практиками між містами та регіонами.

Ці та інші міжнародні документи 3 питань гендерної рівності передбачають, що основні напрями діяльності щодо впровадження гендерної рівності (на національному, регіональному чи місцевому рівні) повинні включати: професійну підготовку жінок і нарощування їх потенціалу; 
підвищення рівня поінформованості та зміна уявлень громадськості щодо гендерних ролей чоловіків та жінок; створення мережі партнерських організацій з підтримки просування жінок у сферу політики й управління. Інші можливості підвищення участі жінок у політичному житті та управлінні, в першу чергу, на місцевому рівні, передбачають: використання бюджету як важливого політичного інструменту; посилення роботи на місцях; пропаганда гендерної рівності і агітація за неї; проведення гендерних досліджень, використання різних показників; реформа виборчої і політичної системи; зміна ролі жінок в політиці.

Також міжнародні документи та результати різних національних досліджень свідчать про необхідність застосування гендеру до публічного врядування з питань послуг з водопостачання, яка означає, що місцеві органи влади мають бути відповідальними, чутливими, задіяними та прозорими як щодо чоловіків, так і щодо жінок при плануванні нових систем 3 водопостачання, при їх експлуатації та алокації ресурсів на своїй території. Нерідко в публікаціях зустрічається висновок, що надання послуг водопостачання у домогосподарства $\epsilon$ високо релевантним проявом стосунків між державою та індивідуумами, які по-різному впливають на чоловіків і жінок. У зв'язку з цим рекомендується проводити як аналіз гендерної ситуації на рівні спільнот, так і на рівні домогосподарств, де існує глибоко усталений традиційний розподіл праці між жінками та чоловіками [32, с. 37-38].

Міжнародні та національні структури, які опікуються питаннями гендерної рівності у місцевому самоврядуванні, закликають застосовувати принцип врахування гендерної проблематики шляхом включення її в усі стратегії, програми та заходи з надання послуг в рамках окремих органів місцевого самоврядування та їх асоціацій на національному, регіональному та міжнародному рівнях, розробляти методи моніторингу і оцінки такого роду роботи; вишукувати нові шляхи забезпечення того, щоб 
жінки були представлені в процесі управління на місцях і активно брали участь в ньому, використовуючи формальні, а також неформальні засоби; зміцнювати співробітництво на міжнародному та національному рівнях між органами місцевого самоврядування та їх асоціаціями на національному, регіональному та міжнародному рівнях 3 метою розширення обміну досвідом; розробляти програми і стратегії, які сприяють усуненню перешкод на шляху участі жінок в процесі прийняття рішень на місцевому рівні; розробляти, здійснювати і контролювати плани дій по сприянню створенню рівних можливостей для роботи в муніципальних органах, включаючи рівні можливості щодо найму, просування по службі, винагороди, а також рівні умови праці; домагатися зміни поглядів, що стосуються гендерних питань, шляхом підвищення рівня інформованості в рамках системи освіти, а також політичної та адміністративної структури місцевих органів управління; активно взаємодіяти 3 іншими членами суспільства, включаючи національні гендерні структури і організації, приватний сектор, неурядові організації, професійні об'єднання, жіночі організації, науково-дослідні установи та профспілки тощо.

Розглядаючи гендерні стереотипи та дискримінаційні практики у місцевому самоврядуванні за ознакою статі своєрідними аномаліями у муніципально-правовій сфері, вважаємо, що місцеве самоврядування $\epsilon$ невід'ємною частиною національної структури публічного владарювання у демократичній державі та являє собою рівень влади й управління, що $є$ найбільш близьким до громадян, i, в силу цього, спроможним найкращим чином включати жінок в процес прийняття рішень щодо умов життя територіальних громад та питань місцевого значення, використовувати їх знання, досвід та можливості для сприяння стійкому розвитку територіальних громад. Звідси можна зробити висновок, що місцеве самоврядування відноситься до числа найбільш гендерно 
чутливих інститутів демократії. Наведені вище проблеми міжнародно-правового та конституційно-правового забезпечення принципу гендерної рівності у місцевому самоврядуванні, нажаль, ще не стали предметом пильної уваги вітчизняних вчених-конституціоналістів. Враховуючи серйозні виклики та загрози, які виникають у сфері реалізації та захисту прав людини в цілому, наукова громадськість має висловлювати свою виважену позицію щодо актуальних проблем інституціоналізації та конституювання гендерних прав в цілому та їх послідовної реалізації у житті територіальних громад та діяльності органів місцевого самоврядування, зокрема.

Ці та інші приклади свідчать, що міжнародно-правове визнання існування у людини невідчужуваних природних прав, закріплене за допомогою прийняття міжнародних норм профільного характеру, що містяться в міжнародних актах, привело до формування і чіткого визначення їх мінімуму, незнижуваного на національному рівні. У цьому аспекті місцеве самоврядування, як феномен сучасного конституціоналізму та універсальна форма реалізації практично всіх прав людини, об'єктивно виступає фактором інтернаціоналізації національного та конституціоналізації міжнародного правопорядків [33]. По суті сьогодні можна спостерігати глобалізацію доктрини муніципального права та місцевого самоврядування, а також прав людини у муніципальноправовому вимірі їх реалізації.

На наш погляд, в умовах глобалізації, інформатизації та розвитку сучасних засобів комунікації муніципальне право стає нормативно-правовим інструментом реалізації одного 3 головних завдань сучасності - поєднання в єдине ціле інтересів держави, суспільства та особи, оскільки головний сенс та сутність місцевого самоврядування полягають у тому, щоб на рівні кожної окремо взятої особи здійснювати гармонізацію прав та свобод людини і громадянина 3 інтересами держави та суспільства. Уцьому контексті, 
варто відзначити й те, що серед багатьох турбот сучасного суспільства одна 3 найгостріших проблем - проблема відчуження людей, ксенофобія, патологічний егоцентризм та індивідуалізм. У поєднанні 3 гострими кризовими явищами в економічному та політичному житті ця проблема спричиняє існування цілої низки песимістичних поглядів на долю людства взагалі, свідченням чого $\epsilon$ офіційно визнана ООН «стратегія виживання». Людська цивілізація протягом своєї історії нагромадила цінний досвід подолання ворожнечі і взаємоненависті, досвід, який акумулювався в такій соціальній та духовній цінності, як людська солідарність. Головним засобом забезпечення солідарності стає культура людських взаємин, цивілізований спосіб спілкування, або так звана «комунікативна культура» [34, с. 1]. В змістовно-термінологічному сенсі поняття «комунікація» перебуває в одному ряду 3 близькими за змістом поняттями «взаємодія» (взаємини), «людські стосунки», «взаємообумовленість», «взаємовплив» тощо, зміст яких оптимально характеризує процеси самоорганізації людей за місцем проживання.

Культура комунікацій, що базується на принципах пріоритету соціальних, тобто суспільно-значимих інтересів, діалогічних, рівноправних стосунках, синтезі індивідуальних свобод та спільної відповідальності, перетворюється на рубежі XX та XXI століть на одну 3 домінант суспільного життя, на загальнолюдську норму мислення та поведінки, на «світову етику». У цьому аспекті необхідно усвідомлювати, що перспективи модернізації соціально-економічної, політичної, правової, духовнокультурної та інших систем українського суспільства у даний час визначаються не тільки об'єктивними закономірностями інноваційного розвитку держав в умовах глобалізації та європейської міждержавної інтеграції, процесами зближення правових систем сучасності, а й необхідністю врахування та гармонізації у процесі формування вітчизняного конституціоналізму локального-особистісного фактора та різноманітних 
особистісних та колективних, місцевих, регіональних i державних інтересів, розмаїття історичних, національнокультурних та інших особливостей розвитку територіальних громад як первинної суб'єктної основи муніципальної влади, яка у сучасному світі закономірно визнається основою будь-якого демократичного ладу.

Ілюстративними у цьому аспекті $\epsilon$ положення Всесвітньої декларації місцевого самоврядування [14] про те, що «зміцнення місцевої влади зміцнює націю в цілому шляхом забезпечення ефективнішої та демократичнішої суспільної політики», а також зафіксовані у преамбулі Європейської ландшафтної конвенції [35] мотиви прийняття цього документу, що орієнтують державиучасниці на те, що вони повинні усвідомити, що «ландшафт сприяє формуванню місцевих культур і $\epsilon$ основним компонентом європейської природної та культурної спадщини, який сприяє добробуту людей та консолідації європейської ідентичності» та необхідність визнання того, що «ландшафт $\epsilon$ важливою складовою якості життя людини всюди: в містах і сільській місцевості, у занедбаній місцевості та місцевості високої якості, в місцевості виняткової краси та в звичайній місцевості».

Цікавими $€$ й положення Переглянутої Європейської Хартії щодо участі молоді у громадському житті на місцевому та регіональному рівнях, прийнятої Конгресом місцевих та регіональних влад Ради Європи на 10-й пленарній сесії 21 травня 2003 р. [36, с. 178, 181-182], у якій вказується, що «активна участь молодих людей у процесі ухвалення рішень та громадській діяльності на місцевому і регіональному рівнях має важливе значення, якщо ми дійсно маємо намір побудувати більш демократичне, солідарне і процвітаюче суспільство. ... Підтримуючи і стимулюючи участь молоді у суспільному житті, місцеві і регіональні влади мають сприяти соціальній інтеграції молодих людей, допомагаючи їм долати не лише проблеми та труднощі, але й знаходити відповідь на виклики сучасного суспільства, в якому часто домінують егоїзм та 
індивідуалізм. Проте для того, щоб участь молоді в суспільному житті на місцевому і регіональному рівнях була успішною, постійною і осмисленою, потрібно мати щось більше, ніж розвиток політичних чи адміністративних систем. Будь-яку політику чи дію, покликану активізувати участь молоді в житті суспільства, має забезпечувати культурне середовище, що поважає молодь і враховує різноманітні потреби, обставини та сподівання молодих людей».

У контексті порушеної нами тематики варто звернути увагу на положення частини I.5 «Політика мобільності і обмінів» цього документу, у якій вказується, що місцевим і регіональним владам слід підтримувати об'єднання чи групи, що виступають за підвищення мобільності молодих людей (молодих працівників, студентів або добровольців) через політику обмінів і розвивати політику зв'язків та усвідомлення себе громадянами Європи. Місцевим i регіональним владам слід заохочувати молодих людей, їх організації та навчальні заклади до активної участі в міжнародній діяльності, усіх видах обмінів та роботі в європейських мережах. Місцеві влади повинні бути готовими надати їм фінансову підтримку 3 метою сприяння вивченню мов і міжкультурним обмінам, а також обміну досвідом.

Важливою $є$ роль місцевого самоврядування у реалізації та захисті прав осіб з особливими потребами. Так, одними 3 мотивів прийняття Конвенції про права осіб з інвалідністю [37], стало розуміння того, що інвалідність - це поняття, яке еволюціонує, і що інвалідність є результатом взаємодії, яка відбувається між людьми, які мають порушення здоров'я, і відносницькими та середовищними бар'єрами і яка заважає їхній повній та ефективній участі в житті суспільства нарівні з іншими, а також визнання цінного нинішнього і потенційного внеску осіб з інвалідністю у загальний добробут i багатоманітність їхніх місцевих товариств i ту обставину, що сприяння повному здійсненню особами з інвалідністю своїх прав людини та 
основоположних свобод, а також повноцінній участі осіб з інвалідністю дасть змогу зміцнити в них почуття причетності й досягти значних успіхів у людському, соціальному та економічному розвитку суспільства та викоріненні бідності (Преамбула).

Відповідно до ст. 19 цього документу, яка має назву «Самостійний спосіб життя й залучення до місцевої спільноти», держави-учасниці цієї Конвенції визнають рівне право всіх осіб з інвалідністю жити у звичайних місцях проживання, коли варіанти вибору $\epsilon$ рівними 3 іншими людьми, i вживають ефективних i належних заходів для того, щоб сприяти повній реалізації особами з інвалідністю цього права та повному включенню й залученню їх до місцевої спільноти, зокрема забезпечуючи, щоб: а) особи з інвалідністю мали можливість вибирати нарівні з іншими людьми своє місце проживання й те, де й 3 ким проживати, і не були зобов'язані проживати в якихось визначених житлових умовах; b) особи 3 інвалідністю мали доступ до різного роду послуг, що надаються вдома, за місцем проживання, та інших допоміжних послуг на базі місцевої спільноти, зокрема персональної допомоги, необхідної для підтримки життя в місцевій спільноті й уключення до неї, та 3 метою недопущення ізоляції або сегрегації від місцевої спільноти; c) послуги та об'єкти колективного користування, призначені для населення в цілому, були рівною мірою доступні для осіб з інвалідністю і відповідали їхнім потребам.

Свідченням перманентного розширення муніципальних прав людини $є$ європейська практика їх надання постійнім мешканцям-іноземцям. Так, ще у 1992 р. у рамках Ради Європи була прийнята Європейська конвенція про участь іноземців у суспільному житті на місцевому рівні [38], якою встановлюється принцип, згідно 3 яким іноземним громадянам гарантуються громадянські та політичні права, включно з правом брати участь у виборах. Так, згідно частини першої ст. 6 цього документу передба- 
Права людини в Україні та у зарубіжних країнах:

проблеми теорії та нормативно-правової регламентації

чається зобов'язання держав-учасників Конвенції надати кожному постійному мешканцю-іноземцю право голосувати та висувати свою кандидатуру на виборах до органів місцевого самоврядування, якщо він задовольняє тим правовим вимогам, які пред'являються громадянам i, крім того, на законних підставах постійно мешкає у відповідній державі упродовж п'яти років, що передують виборам. Також встановлюється, що ценз осілості, передбачений у статті 6, може становити і менший період (ст. 7).

Такий підхід є свідченням того, що у державах сучасної Європи відбувається кардинальне переосмислення сутності та змісту конституційного права на участь в управлінні публічними справами у розрізі муніципальної демократії: якщо держава має справи громадянами, іноземцями, особами без громадянства, біженцями, то місцеве самоврядування - 3 мешканцями. Держави-члени Ради Європи, які підписали Європейську хартію місцевого самоврядування, вважають, що право громадян брати участь в управлінні державними та суспільними справами належить до загальних для всіх держав демократичних приписів, і це право безпосередньо може бути здійснено саме на місцевому рівні.

Стратегічний момент у розумінні цієї проблеми полягає в еволюції загального конституційного правового статусу людини в місцевому самоврядуванні. На рівні територіальних громад цілком змінюється система координат, яка панує в державі щодо прав людини. 3 рівня «громадянин - держава» права людини переходять на рівень «мешканець - орган місцевого самоврядування» та трансформуються у муніципальні права особи.

Цей підхід, який існує в країнах сучасної Європи (наприклад у Данії, Бельгії, Польщі, Латвії), безпосередньо пов'язаний із визнанням відмінності різних статусів публічної влади: державної влади як представника суспільства в цілому, його політичної влади та місцевого самоврядування - як публічної влади територіального 
колективу. Так, наприклад, згідно з частиною 2 §70 Конституції Угорської Республіки 1949 року на виборах до місцевого самоврядування та виборах міського голови виборче право, а також право участі в місцевому референдумі та місцевій народній ініціативі згідно особливого закону - належить також не угорським громадянам, які проживають на території Угорської Республіки як іммігранти, якщо вони на день виборів або, відповідно, референдуму, знаходяться на території країни. Згідно ст. 130 Конституції Королівства Нідерланди 1983 року право участі в виборах муніципальних рад та бути обраним до їх складу може бути надано Актом парламенту особам, які не $\epsilon$ громадянами Нідерландів, але постійно проживають в муніципалітетах, якщо вони відповідають тим саме виборчим цензам, що і громадяни Нідерландів.

Такий підхід є свідченням підвищення ролі муніципальнотериторіального чинника в житті суспільства, створенням дієздатних територіальних громад, підтвердженням демократичних намірів національних держав та їх особливої уваги саме до мешканців певних територій.

Однією з найбільш складних, суперечливих та таких, які вкрай неоднозначно сприймаються та вирішуються у сучасному світі, $\epsilon$ проблема прав сексуальних меншин. Попри те, що майже усе XX ст. пройшло під прапором боротьби сексуальних меншин за свої права, й сьогодні залишається чимало проблем у даній сфері. Враховуючи, що права людини за ознаками сексуальної ідентичності переважною мірою порушуються саме на локальному рівні: адже життєвим простором існування цієї категорії людей є, насамперед, територіальна громада, - питання прав сексуальних меншин об'єктивно може розглядатися і в аспекті формування та реалізації муніципальних прав людини. Свідченням тому $є$, зокрема, позиція Конгресу місцевих і регіональних влад Ради Європи, який звернув увагу на необхідність подолання проблеми дискримінації сексуальних меншин. Відповідно до позиції даної установи, гомофобні інциденти у ряді держав-членів свідчать не 
тільки про систематичні порушення основних прав ЛГБТ, а і показують, що в багатьох випадках органи влади, на які покладено позитивний обов'язок захисту громадян від дискримінації, фактично заохочують несправедливість та сприяють неправомірному обмеженню прав. На запобігання та протидію дискримінації у державах-членах Ради Європи 2007 р. Конгресом було прийнято Рекомендацію 211(2007) «Про свободу зборів і висловлювання думок для лесбійок, геїв, бісексуалів і трансгендерних осіб» [39]. Враховуючи, що свобода вираження думки і свобода зборів $\epsilon$ ядром демократичного суспільства і що роль влади у захисті цих прав $є$ фундаментальною, Конгрес місцевих і регіональних влад Ради Європи запропонував модель імплементації цих прав на місцевому рівні держав-членів без дискримінації за ознакою сексуальної орієнтації та гендерної ідентичності. Як зазначається у даних Рекомендаціях, право висловлювати думку та виражати свою ідентичність 3 іншими людьми $\epsilon$ невід'ємною частиною толерантності - принципу захисту різноманітності суспільства шляхом вільного обміну ідеями, які можуть привести до збагачення на рівні індивіда та суспільства. Ці свободи, природно, несуть 3 собою певні обов'язки і відповідальність і, тому, як держава, так і регіональні або місцеві органи можуть встановлювати обмеження тільки там, де вони передбачені законом. Беручи до уваги, що свобода слова i зібрань лежить в основі демократичного суспільства, а також те, що роль місцевої влади в підтримці цих прав має основоположне значення, Конгрес місцевих і регіональних влад здійснив огляд реалізації цих прав на місцевому рівні по всій Європі та рекомендував країнам-членам Ради Європи забезпечити, щоб вони публічно виступали проти дискримінації за ознакою належності до сексуальних меншин; здійснювали заходи щодо боротьби 3 пропагандою ненависті на даному грунті, з усією строгістю розслідували усі випадки насильства або розпалювання ненависті щодо ЛГБТ, визначали, чи $є$ ці дії дискримінацією 
або гомофобією, можливо, зіграли певну роль у вчиненні злочину, забезпечували судове переслідування винних; в разі необхідності здійснювали позитивні заходи відповідно до вимог Європейського суду 3 прав людини; щоб гарантувати реалізацію свободи зібрань і висловлювання як на державному, так і місцевому та регіональному рівнях; забезпечували можливості ЛГБТ-груп проводити консультації при реформуванні будь-якого з вищевказаних заходів з точки зору взаємної вигоди всіх зацікавлених сторін і розвивали дух співпраці, а не конфронтації. Конгрес звернув увагу на те, щоб усі місцеві влади були в курсі всіх нових законодавчих норм і відповідного прецедентного права, що стосується свободи зібрань i висловлення думок i антидискримінаційних заходів. На думку Конгресу, надання фінансової або іншої підтримки з боку місцевої влади організаторам заходів ЛГБТ-спільноти має бути забезпечене в рівній мірі щодо всіх подібних груп, при цьому не повинно бути ніяких законодавчих заборон місцевим органам влади, які надають допомогу або рекламують події ЛГБТ-спільноти тощо.

Зазначені приклади значною мірою вказують на місце та роль місцевого самоврядування у процесах глобалізації, міжнародної міждержавної інтеграції та формування сучасного конституційного гуманітарного права. Муніципальні права людини та дієздатне місцеве самоврядування $\epsilon$ одним 3 тих атрибутів сучасного конституціоналізму та соціально-правової демократичної державності, що, у контексті європейського вектору розвитку української держави, вимагає свого усебічного конституювання та інституціоналізації на принципах гуманізму, людського виміру публічної влади та верховенства права.

\section{Висновки}

1. Концептуально-конституційний аналіз прав людини у місцевому самоврядуванні свідчить, що вони входять до 
категорії загальних конституційних прав громадян, а тому і до загальної конституційної правосуб'єктності. Однак, реалізація даного виду прав викликає до життя спеціальну правосуб'єктність особи - муніципальну правосуб'єктність, яка включає муніципальну правоздатність і, відповідно, муніципальну дієздатність та муніципальну деліктоздатність людини у сфері місцевого самоврядування. Фактично загальні конституційні права у місцевому самоврядуванні трансформуються у спеціальні суб'єктивні права та обов'язки, характеризувати які можна лише 3 урахуванням мети вступу особи у правовідносини у сфері місцевого самоврядування та їх об’єкта - питань місцевого значення. Важливо при цьому враховувати, що конкретні форми і механізми взаємодії (а часом і взаємопроникнення) інститутів основних прав та свобод людини і громадянина 3 інститутами місцевого самоврядування можуть бути різні.

2. Концептуальний аналіз системи конституційних прав та свобод людини i громадянина у зіставленні із муніципальним рівнем їх можливої реалізації, а іноді і захисту, пояснюється прагненням показати особливе місце та роль у цій системі прав та свобод людини і громадянина у сфері місцевого самоврядування. Це специфічний, обумовлений як способом нормативної фіксації, так i механізмами реалізації, комплекс прав та свобод людини і громадянина, який включає загальновизнані та конституційно закріплені права та свободи, але такі, що реалізуються у межах території, на яку розповсюджується юрисдикція відповідної територіальної громади та такі, що мають своєю метою організацію та здійснення місцевого самоврядування на демократичній основі із використанням конституційно-правових інститутів.

3. В умовах глобалізації та модернізації національної державності форми і механізми взаємодії інститутів основних прав та свобод людини i громадянина 3 інститутами місцевого самоврядування багато у чому визначаються не тільки самобутніми традиціями розвитку 
місцевого самоврядування, специфікою історичних умов його становлення, особливостями поєднання в даному інституті індивідуально-особистісних і колективістських начал, а і відповідними процесами транснаціоналізації конституційного та муніципального права.

\section{Список використаних джерел:}

1. Wheeler N. J. Pluralist and Solidarist Conception of International Society: Bull and Vincent on Humanitarian Intervention. Millennium: Journal of International Studies. 1992. № 21. P. 463-489.

2. Foreign Policy and Human Rights. Issues and Responses / ed. by R. J. Vincent. Cambridge: Cambridge University Press, 1986. 283 p.

3. Donnelly J. Human Rights: a new standard of civilization? International Affairs. 1998. Vol. 74. № 1. P. 1-23.

4. Foreign Policy and Human Rights. Issues and Responses / ed. by R. J. Vincent. Cambridge: Cambridge University Press, 1986. 283 p.

5. Горбатенко В. П. Громадянськість. Юридична енциклопедія: в 6 т. / [редкол.: Ю. С. Шемшученко (голова) та ін.]. Київ: Вид-во «Українська енциклопедія» імені М. П. Бажана, 1998-2004. Т. 1: А-Г. 1998. 672 с.

6. Гареева Л. Г. Институт гражданственности: сравнительный социологический анализ городов разной людности (на примере городов Урала): автореф. дис. на соискание учен. степени канд. социол. наук: спец. 22.00.04 «Социальная структура, социальные институты и процессы». Екатеринбург, 2008. 19 с.

7. Еремин А. Р. Реализация права человека и гражданина на местное самоуправление в Российской Федерации: Конституционные вопросы: автореф. дис. на соискание учен. степени доктора юрид. наук: спец. 12.00.02 «Конституционное право; муниципальное право». Саратов, $2003.58 \mathrm{c}$.

8. Батанов O. В. Муніципальна влада та проблеми співвідношення колективізму, індивідуалізму та автономії 
особистості у місцевому самоврядуванні. Формування правової держави в Україні: проблеми $і$ перспективи: матеріали IX Всеукраїнської наук.-прак. конф. (м. Тернопіль, 13 квітня 2007 р.). Ч. І. Тернопіль: Економічна думка, 2007. C. 209-215.

9. Бондарь Н. С. Гражданин и публичная власть: Конституционное обеспечение прав и свобод в местном самоуправлении: учеб. пособие. Москва: ОАО «Издательский дом "Городец"», 2004. 352 с.

10. Зайцева I. О. Конституційно-правове забезпечення статутної нормотворчості у місцевому самоврядуванні в Україні: автореф. дис. на здобуття наук. ступеня канд. юрид. наук: спец. 12.00.02 «Конституційне право; муніципальне право». Маріупольський державний університет. Маріуполь, 2013. 22 с.

11. Рекомендація Конгресу місцевих і регіональних Влад Європи 280(2010) про роль місцевих і регіональних органів влади в дотриманні прав людини (переглянута) від 19 жовтня 2011 року. Досвід децентралізації у країнах Європи: зб. док. Пер. з іноз. мов. Заг. ред. В. Б. Гройсмана. Київ: Інститут законодавства Верховної Ради України, 2015. 766 c.

12. Декларація щодо забезпечення доброго врядування на місцевому і регіональному рівнях, ухвалена на 14-й сесії Європейської Конференції міністрів держав-членів Ради Європи, відповідальних за регіональне та місцеве врядування (м. Будапешт, Угорська Республіка, 24-25 лютого 2005 року). Збірник "Досвід впровадження стандартів доброго врядування на місцевому рівні в Україні та інших європейських країнах». В. С. Куйбіда, В. В. Толкованов. Київ, ТОВ «Поліграфічний Центр «Крамар», 2010. 258 с.

13. Європейська Хартія місцевого самоврядування. Страсбург, 15 жовтня 1985 року. Сайт Верховної Ради України. URL: http://zakon2.rada.gov.ua/laws/show/994_036

14. Всесвітня декларація місцевого самоврядування 1985 р. Ріо-де-Жанейро, 23-26 вересня 1985 року. Переклад 
3 англійської Ірини Дроздовської. Місцеве та регіональне самоврядування України. Вип. 1-2 (6-7). Київ, 1994. С. 65-69.

15. Європейська рамкова конвенція про транскордонне співробітництво між територіальними общинами або властями. Мадрід, 21 травня 1980 року Сайт Верховної Ради України. URL: http://zakon2.rada.gov.ua/laws/show/ 995_106

16. Всемирная хартия местного самоуправления. Проект. Найроби, 8-12 мая 2000 года. URL: www.un.org/russian/documen/gadocs/25spec/crp7.doc

17. Декларация о принципах местного самоуправления в государствах-участниках Содружества. 29 октября 1994 года. Информационный бюллетень Межпарламентской Ассамблеи государств-участников Содружества Независимых Государств. 1995. № 6. С. 85-89.

18. Стамбульская декларация по населенным пунктам. Стамбул, 14 июня 1996 г. Сайт Верховної Ради України. URL: http://zakon4.rada.gov.ua/laws/show/995_508

19. Екологічна Угода Міст. Підписана 3 нагоди Всесвітнього Дня Довкілля проведеного в рамках Екологічної програми Організації Об’єднаних Націй 5 червня 2005 року у Сан-Франциско, Каліфорнія. Офіційний інтернет-сайт Київської міської ради. URL: http://kmr.gov.ua/divinfo.asp?Id=241

20. Аналіз вразливості жінок та чоловіків в контексті децентралізації на територіях України, що постраждали від конфлікту. Нікого не залишити осторонь. Звіт. Вересень 2017. Підготовлений у рамках спільної програми ПРООН та ООН Жінки «Відновлення управління та сприяння примиренню в постраждалих від кризи громадах України». 72 с.

21. Суслова І. Участь жінок в Українській політиці. Вісник Центральної виборчої комісії. 2016. № 2 (34). С. 18-19.

22. Гендерна рівність у місцевому політичному житті та гендерна концепція у місцевій політиці в Україні. Документ до обговорення підготовлений п. Вишнею Бачановіч, консультантом 3 гендерної рівності за координації Департаменту співробітництва та зовнішніх відносин 
Секретаріату Конгресу місцевих та регіональних влад Ради Європи. Лютий 2018. 38 с.

23. Гендерний моніторинг виборів. Молодий вік для чоловіків - перевага, а для жінок - недолік. Жінки у політиці, 2 листопада 2015 p. URL: http://vybory2012.wcunetwork.org.ua/Gendernii_montoring_viborv_Molodii_vk_dlja_c holovkv_-_perevaga_a_dlja_zhnok_\%E2\%80\%93_nedolk

24. Семра Амет. Сприяння гендерній політиці в діяльності асоціацій та органів місцевої влади. Кращі практики Спілки асоціацій місцевих органів влади південносхідної Європи (NALAS) URL: https://www.auc.org.ua/sites/ default/files/semra_nalas_-_gender_mainstreaming_at_local_ level_upd_ukr.pdf

25. Декларация о городах и других населенных пунктах в новом тысячелетии: Принята резолюцией S-25/2 специальной сессии Генеральной Ассамблеи от 9 июня 2001 года. Сайт Верховної Ради України. URL: http://zakon.rada.gov.ua/laws/show/ru/995_849

26. Всемирная декларация Международного союза местных органов власти (МСМОВ) о роли женщин в местном самоуправлении (Зимбабве. 1998 г.). Участие женщин в руководстве городами. URL: http://www.owl.ru/win/docum/un/habitat/declar.htm

27. Гендерний підхід: Концепція, методологія та презентація кращих практик, Рада Європи, 2014 р., м. Страсбург, с. 41. URL: https://rm.coe.int/1680596135

28. Рекомендація 148 (2004) про гендерний підхід на місцевому та регіональному рівнях: стратегія сприяння рівності між жінками та чоловіками в містах та регіонах. Конгрес місцевих та регіональних влад Ради Європи, 27 травня 2004 рік. URL: https://rm.coe.int/168071a54

29. Резолюція 176 (2004) про гендерний підхід на місцевому та регіональному рівнях: стратегія сприяння рівності між жінками та чоловіками в містах та регіонах. Конгрес місцевих та регіональних влад Ради Європи, 27 травня 2004 рік. URL: https://rm.coe.int/16807191f2 
Права людини в Україні та у зарубіжних країнах:

проблеми теорії та нормативно-правової регламентації

30. Резолюція 405(2016) та Пояснювальний меморандум про гендерне бюджетування, CG 31(2016)10 final, Комітет управління Конгресу місцевих та регіональних влад Ради Європи, 21 жовтня 2016 р. URL: https://rm.coe.int/1680718ce9

31. Резолюція 391(2015) про боротьбу із зростаючою бідністю серед жінок: відповідальність місцевих та регіональних органів влади, Конгрес Ради Європи, 21 жовтня 2015 p. URL: https://rm.coe.int/16807199f1

32. Європейська хартія рівності жінок і чоловіків у житті місцевих громад, Рада Європейських муніципалітетів та регіонів, травень 2006 рік, м. Інсбрук. URL: http://www.ccre.org/docs/charte_egalite_en.pdf

33. Аналітичний звіт «Децентралізація та місцеве врядування як потенціал гендерної рівності» (Заключний). Підготовлений БФ «Інтелектуальна перспектива». Київ, 2011. С. 37-38.

34. Баймуратов М. Місцеве самоврядування як фактор інтернаціоналізації національного та конституціоналізації міжнародного правопорядків. Юридичний журнал: Аналіт. матеріали. Коментарі. Судова практика. 2011. № 12. C. 24-31.

35. Сарновська С. О. Сучасна соціальна комунікативна культура (філософсько-методологічний аналіз): автореф. дис. на здобуття наук. ступеня канд. філос. наук : спец. 09.00.03 «Соціальна філософія та філософія історії»; Ін-т філос. ім. Г.С. Сковороди НАН України. Київ, 2000. 18 с.

36. Європейська ландшафтна конвенція. Флоренція, 20 жовтня 2000 року. Сайт Верховної Ради України. URL: http://zakon4.rada.gov.ua/ laws/show/994_154

37. Переглянута Європейська Хартія щодо участі молоді у громадському житті на місцевому та регіональному рівнях. Прийнята Конгресом місцевих та регіональних влад Ради Європи на 10-й пленарній сесії 21 травня 2003 р. Збірник "Досвід впровадження стандартів доброго врядування на місцевому рівні в Україні та інших 
Права людини в Україні та у зарубіжних країнах:

проблеми теорії та нормативно-правової регламентації

європейських країнах». В. С. Куйбіда, В. В. Толкованов. Київ, ТОВ «Поліграфічний Центр «Крамар», 2010. 258 с.

38. Конвенція про права осіб з інвалідністю. ГА ООН, 13 грудня 2006 p. Сайт Верховної Ради України. URL: http://zakon3.rada.gov.ua/laws/show/995_g71/page

39. Європейська конвенція про участь іноземців у суспільному житті на місцевому рівні. Страсбург, 5 лютого 1992 року. Сайт Верховної Ради України. URL: http://zakon3.rada.gov.ua/laws/show/994_318

40. Recommendation 211 (2007) Freedom of assembly and expression for lesbians, gays, bisexuals and transgendered persons. The Congress of Local and Regional Authorities. URL: https://wcd.coe.int/ViewDoc.jsp?id=1099699\&Site=Congress. 
Права людини в Україні та у зарубіжних країнах:

проблеми теорії та нормативно-правової регламентації

DOI https://doi.org/10.36059/978-966-397-210-7/45-66

\author{
Васильченко О. П., \\ доктор юридичних наук, професор, \\ професор кафедри конституційного права \\ юридичного факультету \\ Київського національного університету \\ імені Тараса Шевченка, \\ м. Київ
}

Mamam A. B., аспірант кафедри конституційного права юридичного факультету Київського національного університету імені Тараса Шевченка, м. Київ

\title{
КОНСТИТУЦЙНІ ПРАВА ЛЮДИНИ: ЗМІСТ, ФУНКЦІЇ ТА РАМКИ ОБМЕЖЕННЯ
}

Анотація. Уроботі досліджується концепція прав людини, а також аналізується значення конституційних прав людини. Співставлено поняття «конституційні права людини», «основні права людини» та «фундаментальні права людини». Розглянуто функції прав людини та визначено функціональні особливості таких прав. Досліджено функції конституційних (основних) прав за матеріалами німецької правничої доктрини, до яких належить: оборонна функція, функція надання благ та захисту, функція однакового поводження. Розглянуто теоретичні та практичні підходи до обмеження прав людини і втручання у приватну автономію особи. Проаналізовано західні стандарти, за якими досліджується допустимість обмеження прав людини. Розглянуто деякі приклади захисту Конституційним Судом України конституційних прав людини від неконституційного їх обмеження. Наведено аналіз впроваджених карантинних заходів у зв'язку із пандемією коронавірусу (COVID-19) та правомірності обмежень конституційних прав людини в Україні. 
Права людини в Україні та у зарубіжних країнах:

проблеми теорії та нормативно-правової регламентації

\section{Вступ}

Дослідження прав людини завжди привертають увагу представників різних галузей знань, а також $є$ актуальною проблемою, яка загалом постійно розвивається та уособлює спільну ціннісну орієнтацією для сучасного світу. Залежно від різних умов (історичних, соціальних, економічних тощо) кожна окрема демократична держава має свій рівень гарантій та захисту прав людини. Проте виклики, з якими стикаються держави в умовах демократії, завжди мають дилему: як вирішити ту чи іншу проблему, не порушуючи при цьому права людини.

Сьогоднішні реалії глобального світу стали такою проблемою як для демократій зокрема, так і для сучасного світу загалом. Права людини не $є$ статичним терміном, який вивчають різні галузі знань, оскільки права людини виступають реальною та динамічною категорією. Із розвитком суспільства права людини набувають відповідно ширших характеристик, що, з одного боку наповнюють їх універсальним змістом, а 3 іншого ускладнюють їх практику реалізації.

Від таких загальних вступних тез можемо перейти до більш точкової проблеми в рамках представленої теми значення конституційних прав людини, їх функції та рамки обмеження.

Запропонована проблематика актуалізується сучасними обставинами, в яких перебувають держави у зв'язку із визнанням Всесвітньою організацією охорони здоров'я пандемії коронавірусної інфекції (COVID-19) [1] та запровадженням карантинних обмежень у світі. Такі обставини стали неабияким викликом для демократичних держав, які запроваджують різного рівня карантинні заходи, а тому підсилюють актуальність питання про обмеження конституційних прав у надзвичайних умовах.

Тема прав людини 3 різних точок зору правничих досліджень, зрозуміло, представлена у більшості наукових праць. Можемо виділити тих науковців, дослідження яких 
стали об’єктом нашої уваги, зокрема: І. Дахова, М. Козюбра, С. Максимов, М. Орзіх, П. Рабінович, С. Рабінович, В. Речицький, М. Савчин, Н. Сатохіна, О. Уварова, С. Шевчук та інші.

Питання функцій прав людини та окремо питання обмеження прав також становлять неабиякий інтерес у дослідників різних галузей права. До слова, обмеження прав людини є однією із складних проблем зі сфери прав людини, оскільки обмеження $\epsilon$ допустимими для прав людини у визначених випадках, проте не усі такі обмеження можуть вважатися правомірними.

Названа проблематика включає в себе не лише теоретичні підходи, які можна знайти у правничій доктрині, а також $є$ проблемою практичного рівня, яка потребує відповідних законодавчих гарантій та належного судового захисту у випадках неправомірного обмеження прав людини.

Як уже було сказано вище, тематика прав людини набуває нових штрихів для наукових розвідок, посилаючись на світовий карантин, викликаний поширенням пандемії коронавірусну (COVID-19). Так, більшість карантинних заходів $є$ прямим обмеженням саме конституційних прав людини, що потребує проведення відповідного наукового дослідження для виявлення та запобігання можливих проблем зі сфери прав людини у майбутньому.

Таким чином, у рамках запропонованої проблематики ми розглянемо деякі аспекти теоретичного обгрунтування конституційних прав людини, 3'ясуємо їх функціональні особливості та визначимо рамки обмеження. Наперед зауважимо, що окреслений вектор дослідження $\epsilon$ дискусійною та складною темою сьогодні, а тому 3 об'єктивних причин ми не зможемо обхопити увесь обсяг питань, оскільки для цього ще знадобиться певний час. Разом 3 тим можемо брати ту інформацію, яка $\epsilon$ у відкритому доступі та піддається науковому аналізу i дискусії. 
Права людини в Україні та у зарубіжних країнах:

проблеми теорії та нормативно-правової регламентації

\section{1. Загальнотеоретична характеристика конституційних прав людини}

Права людини як концепція, що включає у себе різні філософські та правові засади, $є$ багатоаспектним явищем. Не обмежуючись винятково правничою доктриною, права людини намагаються визначити у різний спосіб, проте єдиного їх визначення все ж знайти не вдається.

Говорячи загалом про термінопоняття «права людини», слід розуміти, що виклики XX століття стали однією із найбільш проблемних та складних для формування каталогу прав людини в наші дні. Так, за висловленням американського історика Т. Снайдера, який написав кину «Про тиранію: 20 уроків XX століття» [2], минуле століття було найбільш жорстоким у контексті прав людини, а разом з тим - саме у XX столітті каталог людських прав почав фундаментально закріплюватись на міжнародному рівні. На все це найбільше вплинула Друга світова війна, яка показала усі жахливі наслідки нелюдського поводження, геноциду та масового знищення для людства.

Проте, на жаль, ми не можемо стверджувати, що XXI століття не має загрозливих наслідків для прав людини. Навіть при тому, що, як уже було зазначено, розуміння прав людини навіть на рівні доктринальних підходів має різні варіанти.

Звернемо увагу на деякі загальнотеоретичні дані, які допоможуть розкрити зміст прав людини в рамках правничої науки.

Як випливає із аналізу філософської думки, підходи до розуміння прав людини залежать від багатьох чинників цивілізаційних, ідеологічних, політичних, соціокультурних, етичних, етноправових, та їх взаємовідносин з правом. Досі точаться дискусії (особливо серед філософів) щодо того, що собою становлять права людини - моральну чи юридичну категорію, яке їх співвідношення з державою: передують вони їхньому визнанню державою чи стають правами людини лише внаслідок їх визнання нею; в яких формах 
таке визнання відбувається; чи існують універсально значущі, загальновизнані права людини тощо [3, с. 49].

Як зазначає Н. Сатохіна у своєму дослідженні про обгрунтування прав людини, «права людини як суб'єктивні права людської істоти вперше отримують метафізичне обгрунтування у християнстві: оскільки кожна людина має душу, пов'язану 3 Богом, кожна людина $\epsilon$ носієм абсолютної цінності - людської гідності, яка і $\epsilon$ підставою наявності в людини священних та невідчужуваних прав. У Новий час права обгрунтовуються вже не тим, що всі люди створені «за образом і подобою божою», а самою природою людей, зокрема розумною природою» [4, с. 121].

Водночас у західних підходах до розуміння прав людини $\epsilon$ давньогрецький поліс. Відповідно до цієї концепції людина - це самостійний індивід, наділений не просто розумом, а свободою вибору і здатністю самостійно визначати свою долю, тобто індивідуалістично. Останнім часом на європейському континенті помітна тенденція до відмови від нав'язування жорсткого європоцентризму в розумінні прав людини та забезпечення збалансованості між правами особистості та публічними інтересами, зокрема інтересами держави [3, с. 50].

За визначенням Р. Алекзі, категорія «права людини» включає п'ять ознак, які складають її зміст. Так, на думку дослідника, «по-перше, вони застосовуються універсально, тобто носієм цих прав $\epsilon$ кожна людина. Право на життя зобов'язує кожного поважати це право, тобто кожну людину, а також держави і організації. Винятком із загального підходу $\epsilon$ право на участь у політичному прийнятті рішень: це право належить винятково громадянам держави, які $\epsilon$ власниками цього права» $[5$, c. 16$]$.

Підсумовуючи вивчення прав людини, автори підручника загальної теорії права за редакцією М. Козюбри дійшли висновку про те, що «права людини - це визнані світовим співтовариством блага й умови життя, яких може домагатися особа від держави і суспільства, в яких вона 
живе, та забезпечення яких реальне в умовах досягнутого людством прогресу» [3, с. 50].

Таким чином, на нашу думку, права людини стали ціннісним орієнтиром для цивілізованого світу, який у сучасних умовах не може розвиватись без прав людини. Водночас сфера прав людини утвердилась не лише як загальнотеоретична концепція, а також сформувалась на рівні відповідного правового статусу. Тому далі буде йтися про конституційну регламентацію прав людини.

Слід відзначити, що зміст прав людини складає відповідна класифікація таких прав. Серед іншого, сьогодні права людини гарантуються на рівні конституцій, конституційних актів та міжнародно-правових документів. Таким чином, права людини називають конституційними, фундаментальними, основними тощо. Взаємозумовленість та взаємозалежність термінів конституційні, основні та фундаментальні права людини продемонструємо далі.

У теорії конституційного права правам людини приділяється окрема увага. Оскільки права людини є інститутом конституційного права багатьох держав зазвичай підходи до конституційних прав людини базуються на інтеграції двох основних напрямів юридичної теорії: природно-правового та позитивістського. Природноправові теорії розглядають людину як істоту, яка має невіддільні від ії̈ буття права, що випливають або 3 розуму, або з божественної волі, або з природи людини. Позитивістські ж теорії підходять до прав людини як до категорії, що встановлюється державою. Поєднання цих двох напрямів практично здійснюється шляхом прийняття конкретних конституційних положень або «Білля про права». Тому права людини набувають юридичної форми і стають одним із важливих інститутів конституційного права [6, с. 17].

Здебільшого фундаментальні права людини визнаються державами безпосередньо діючим правом. При цьому неважливо, мають вони відповідне закріплення в законах чи ні. Існують країни, в яких права людини законодавчо не 
зафіксовані, проте це не позбавляє кожну людину права не бути підданою катуванню, довільно заарештованою, неправомірно обмеженою в свободі слова тощо. Навпаки, це означає, що закріплення прав людини у конституціях та законах - важливий, але часто не визначальний крок для їх визнання державами. Все залежить від рівня забезпеченості прав людини, зокрема від розвинутості юридичних засобів і процедур їх реалізації та захисту $[3$, c. 52].

Порівнюючи фундаментальні права 3 основними правами, слід звернутися до німецької доктрини, оскільки за таким підходом конституційними правами $\epsilon$ основні права на підставі Основного Закону ФРН.

Так, А. Вільдтом, порівнюючи фундаментальні права 3 основними правами людини, зазначає про те, що «ідея фундаментальних прав або «основних прав» $\epsilon$ нині двозначною. По-перше, її можна тлумачити таким чином, що ці права $\epsilon$ найзагальнішими правами, за допомогою яких обгрунтовуються чи легітимізуються спеціальні права. Цей аспект виходить на передній план передусім тоді, коли наголошують на універсальності прав людини. По-друге, під «фундаментальними» правами мають на увазі також найважливіші за змістом права, тобто принаймні інваріантне ядро мінімальних прав. Цей аспект виходить на передній план тоді, коли виявляється недоторканність та невіддільність прав людини» [7, с. 119].

Можна зробити узагальнення про те, що ідея основних прав за німецькою доктриною має достатньо спільного 3 концепцією фундаментальних прав, яка втілена у Загальній декларації прав людини та, пізніше, у Конвенції про захист прав людини і основоположних свобод. Таким чином, сформовано беззаперечну ідею про те, що права людини уособлюють собою цінність у глобальному сенсі.

Основний Закон ФРН, який було прийнято 23 травня 1949 року, закріплює перелік основних прав, тобто конституційно гарантованих прав людини, у Розділі I «Основні права», який включає 22 статті (разом 3 
поправками). Так, серед основних прав за Основним Законом ФРН можна виділити такі: захист людської гідності (ст. 1), особиста свобода (ст. 2), рівність перед законом (ст. 3), свобода віри, совісті та віросповідання (ст. 4), свобода вираження поглядів (ст. 5), а також інші [8].

Між тим, в американському конституціоналізмі, як зазначає М. Антонович, не йдеться про правовий статус індивіда як сукупність його прав та обов'язків. Навпаки, постійно підкреслюється, що це сам індивід наділив державу правом і обов'язком контролювати, аби його невіддільні права не порушувались. 3 посиланням на Л. Хенкін вказується, що Конституція США не створює, не встановлює і не дарує права. Вона тільки передбачає, що вже наявні права повинні поважатись урядом. Одна 3 причин того, чому Конституція США спочатку не включала Білля про права, полягала в тому, що ії творці не бачили необхідності захищати права людей, які вже існували, від нового федерального уряду [6, с. 17-18].

Розглядаючи особливості визначення конституційного рівня прав людини в Україні, слід звернути увагу на те, що статтею 22 (1) Конституції України закріплено: «Права і свободи людини і громадянина, закріплені цією Конституцією, не $є$ вичерпними». Разом з тим за статтею 22 (3) визначено, що «При прийнятті нових законів або внесенні змін до чинних законів не допускається звуження змісту та обсягу існуючих прав і свобод». Такий підхід загалом дає підстави зробити висновок про те, що конституційні права людини не обмежені лише текстом Конституції України, а тому мають безпосередній зв'язок із тими гарантіями, які регулюються поточним законодавством, для якого конституційні права людини $є$ джерелом. До слова, за Конституцією України можна виділити перелік прав людини, він $\epsilon$ узгодженим із міжнародними засадами каталогу таких прав. Водночас те чи інше конституційне право людини здебільшого знаходить більш детальний зміст у поточному 
законодавстві (наприклад, право на працю чи відпочинок в нормах трудового законодавства і так далі).

Для аргументації такого твердження наведемо думку М. Савчина, який вказує на те, що «сьогодні посилюється горизонтальний ефект конституцій, згідно 3 яким фундаментальні права людини визначають зміст поточного законодавства, неприпустимість свавільного застосування законодавства, що призводить до посягання сутнісного змісту фундаментального права людини» $[9$, c. 243].

\section{2. Функціональні особливості конституційних прав людини}

Досі залишається поза увагою серед й без того великої кількості наукових досліджень у сфері прав людини питання їх (прав людини) функцій та функціонального призначення. Вивчення проблематики функцій основних прав, а також з'ясування функціонального призначення таких прав є метою представленої статті.

Свого часу Г. Ярас вказував у своєму дослідженні на те, що «коли йдеться про «функції основних прав», то природним $\epsilon$ питання про те, до якого виду належать впливи і юридичні наслідки, що виникають із основних прав. На перший план виступає їхня оборонна функція, що змушує державу утримуватися від певних дій» [10, с. 626].

Водночас широта досліджень прав людини, яка сьогодні представлена у різних напрямах суспільних наук, а найбільше - у правничій науці, набуває всезагального значення як цілісна концепція в сучасних умовах розвитку права, суспільства та держави. Особливе значення мають права людини, які все ще розвиваються та наповнюються новітнім змістом, на який впливають різноманітні фактори: економічні, політичні, соціальні, екологічні тощо.

Права людини в умовах демократії - це також критерії, за якими можна здійснити замір якісних та кількісних показників розвиненості держави. Тому вважаємо, що окремої уваги потребує дослідження функцій прав людини, 
вивчення яких дасть можливість комплексно визначити особливості практики реалізації прав людини. Зазначена теза також підтверджується необхідністю у пошуку нового фокусу досліджень прав людини, зважаючи на перспективи європейської та євроатлантичної інтеграцї̈ України.

Тому пропонуємо розглянути функції конституційних (онсовних) прав людини та з'ясувати їх сутнісне значення.

Перш за все важливо почати 3 питання про те, яку функціональну роль відіграє право як явище соціальної дійсності. До прикладу, на думку авторів Великої української юридичної енциклопедії, «функціональна роль права полягає в тому, що воно виражає загальнолюдські інтереси, певні соціальні прагнення, волю більшості громадян, визначає права, свободи і обов'язки громадян» [11, с. 627].

Взаємозв'язок функціонального призначення права та прав людини можемо пояснити тим, що права людини $\epsilon$ ціннісною орієнтацією для права та суспільних відносин, які покликане регулювати право в сучасних умовах розвитку. Проте сьогодні все ще малодослідженим в українській правничій науці залишається проблема функцій прав людини, яка може розвивати вивчення функцій права.

Передумовою для змістовного дослідження функцій прав людини, видаються цікавими дослідження, які торкаються проблеми обгрунтування прав людини, як це представлено в однойменній публікації Н. Сатохіної. Так, звертається увага на те, що, «незважаючи на широке визнання ідеї прав людини в усьому світі, ці питання не $є$ ані простими, ані риторичними. Ба більше, обгрунтування прав людини сьогодні $є$ не лише ключовою, а й найбільш контроверсійною проблемою філософії прав людини» [4, с. 119].

На переконання Ю. Размєтаєвої, права людини містять ідею гідності, поваги і до інших, і до себе, тому вони деякою мірою виховують людину. Дослідниця також зазначає, що існування громадянського типу суспільства, його формування неможливе без появи нових суспільних індивідів - громадян, які мають рівні права і своєрідні громадянські якості [12, с. 71]. 
Зрештою, функції прав людини - це більшою мірою філософська концепція, крізь приму відповідних методів дослідження ця концепція може бути детально вивченою та обгрунтованою. Завданням правничих досліджень залишається фокус на правах людини загалом, але хаотичні та загальні дослідження з теми прав людини певною мірою заплутують зміст проблематики, що своєю чергою не дає зрозуміти чіткість у вивченні прав людини, зокрема в сучасних умовах розвитку України.

$\mathrm{У}$ цієї проблеми $\epsilon$ щонайменше два пояснення: по-перше, це розуміння прав людини в соціальному (або навіть соціалістичному) контексті, що в загальних рисах позиціонує права людини як соціальні очікування громадян від держави. Це зрозуміло у зв'язку з тим, що тривалий час Україна перебувала під гнітом тоталітарного режиму. Та, по-друге, що логічно пов'язано із першою причиною, це нерозуміння прав людини як фундаментальної цінності в умовах демократії. Для цього важливе значення має переосмислення розуміння ідеї прав людини.

Таким чином, розуміння прав людини - це пряма вказівка на те, що можна включати у визначення поняття функцій прав людини. Зрозуміло, що починати потрібно 3 кореневої проблеми, суть якої окреслено вище. Разом 3 тим, як було зазначено, пошук відповідей на питання про функції прав людини знаходиться у дослідженнях, присвячених філософії права.

Як нами було зазначено на початку, німецький дослідник Г. Ярас, досліджуючи функції основних прав у німецькій доктрині, виділяв серед таких функцій дещо інші, а саме: оборонну функцію, функцію надання благ та захисту, функцію однакового поводження [10, с. 626].

Однією із ключових функцій основних прав, на думку Г.Яраса, слід вважати оборонну. Отже, оборонна функція основних прав дослідником пояснюється на конкретному прикладі: «якщо комусь не дадуть найняти адвоката для захисту і реалізації своїх прав у стосунках з виконавчою владою, слід згадати про оборонну функцію, присутню 
в абзаці четвертому статті 19 Основного Закону Німеччини, яка так само гарантується цим основним правом». Звертають на себе увагу простори можливостей, які в сфері вторинної оборонної функції прав на блага $\epsilon$ значно вужчими, ніж для (первинної) функції надання благ [10, с. 645].

Розглядаючи наступну функцію - надання благ та захисту, Г. Ярас резюмує, що частково функцію захисту розглядають як незалежну, окрему функцію, а всі інші змісти охоплюються поняттям функції надання благ. Обов'язок надавати захист стосується також зобов'язання держави діяти, що існує в трикутнику між носієм основних прав, приватною третьою стороною і державою, тоді як функція надання благ має значення лише в стосунках носія основних прав і держави [10, с. 635].

Насамкінець, серед загальних функцій основних прав, німецький дослідник виділяє функцію однакового поводження. Так, з основних прав на свободи часом навіть сам Федеральний конституційний суд Німеччини виводить обов'язки однакового поводження, зокрема «заборону упослідження» (BVerfGE 105, 313 (346). Наскільки це $\epsilon$ слушним, настільки основним правам на свободи належить вторинна функція - функція однакового поводження або «функція недискримінації» (Jarass. Bausteine (Bibl.). Проте функцію однакового поводження нерідко і за різних умов розуміють як вираження оборонної функції [10, с. 641].

Крім того, як йдеться 3 цього приводу у дослідженні Г.Яраса, Федеральний конституційний суд частково поєднав обов'язки однакового поводження з об'єктивним змістом пов'язаних 3 ними основних прав (VerfGE 80, 124 (133f.); однак об’єктивний зміст відповідних прав сам по собі $\epsilon$ протиставленням, антагонізмом оборонної функції. Разом із тим випадки таких обов'язків однакового поводження зустрічаються нечасто. До того ж чимало конкуруючих спеціальних основних прав рівності мають пріоритет [10, с. 641]. 


\section{3. Рамки обмеження конституційних прав людини}

Розглянувши права людини на рівні конституційної регламентації та дослідивши функціональні особливості права людини, про які лише частково згадується в доктрині, слід перейти до завершальної частини цієї наукової розвідки - рамки обмеження конституційних прав людини.

Наголосимо, що питання обмеження прав людини окрема складна проблематика, оскільки права людини здебільшого не $\epsilon$ абсолютними, а тому можуть обмежуватись. Разом 3 тим такі обмеження мають відповідні межі, про що йтиметься далі.

Як зазначає О. Панкевич у контексті цієї проблеми, «обмеження основних прав $\epsilon$ фундаментальною (базовою) категорією конституційно-правового статусу особи. 3 огляду на те, що абсолютних, «безмежних» прав людини апріорі існувати не може, вважаємо встановлення чітких та зрозумілих критеріїв обмежування таких прав на найвищих (міжнародно-правовому та конституційному) рівнях важливою гарантією від можливих дій держави та її окремих органів щодо свавільного зменшення обсягу правореалізації» [13, с. 146-147].

Як вже було зазначено вище, права людини не слід вважати абсолютними. Тому складність питання обмеження конституційних прав людини полягає в тому, що держава має утримуватися від надмірного втручання у приватну сферу індивіда, але понад тим - будь-яке втручання має бути обгрунтованим, а саме відповідати легітимній меті та бути пропорційним. Загалом конституційний принцип пропорційності відіграє вирішальну роль у контексті обгрунтованості обмеження прав людини.

Досліджуючи обмеження прав i свобод людини, М. Савчин розкриває значення проблеми втручання так: «втручання публічної влади у сферу приватної автономії індивіда виключно на підставі закону, яким запроваджуються певні заходи, спрямовані на забезпечення балансу приватних і публічних інтересів з метою захисту 
національної безпеки, громадського порядку, життя i здоров'я інших людей, авторитету правосуддя» [14, с. 291].

Слід додати, що обмеження конституційних прав людини мають бути тимчасовим необхідним заходом. Так, на думку I. Дахової, «обмеження щодо реалізації прав i свобод людини - це передбачений законом захід тимчасового характеру, що застосовується до особи 3 боку держави». Разом з тим, на думку вченої, для правомірності державного втручання у право людини необхідно, щоб таке втручання здійснювалось задля досягнення легітимної мети, якою завжди є захист певних суспільних або державних цінностей, та була необхідною в демократичному суспільстві [15, с. 22].

Щоб повною мірою визначити, чи не виходить за межі держава під час втручання у права людини, для цього мають бути визначені рамки, які відповідають усталеним міжнародним стандартам. Загалом, за «сучасними європейськими стандартами, до таких належать:

- обмеження мають встановлюватися винятково законами;

- бути пропорційними до визначеної конституцією i законами мети;

- обгрунтовані публічними інтересами, необхідними для нормального функціонування демократичного суспільства, або захистом прав інших людей;

- будь-які обмеження прав мають застосовуватися лише у тому разі, якщо не існує інших, менш обтяжливих заходів досягнення мети забезпечення публічних інтересів, прав інших осіб;

- наслідки обмежень прав не повинні бути надмірними;

- обмеження не повинні спотворювати суть обмежуваних прав» [3, с. 60].

Таким чином, стандартом для визначення допустимих меж втручання у права людини слід вважати вироблений Європейським судом 3 прав людини так званий «трискладовий текст», за яким аналізується наявність 
обмеження прав, яке: 1) має бути передбачене законом 2) повинно мати легітимну мету 3) повинно мати необхідність обмеження в демократичному суспільстві. Цей уніфікований підхід до розуміння принципу пропорційності в конституційному праві став класичним.

За Конституцією України, конституційні права людини не можуть бути обмежені, окрім тих випадків, які передбачені Конституцією. Так, статтею 64 (2) визначено перелік конституційних прав і людини, які не можуть бути обмеженими: «В умовах воєнного або надзвичайного стану можуть встановлюватися окремі обмеження прав і свобод із зазначенням строку дії цих обмежень. Не можуть бути обмежені права і свободи, передбачені статтями 24, 25, 27, $28,29,40,47,51,52,55,56,57,58,59,60,61,62,63$ цієї Конституції».

Таким чином, встановлено, що не підлягають обмеженню рівність прав і свобод, право на життя, право на повагу до гідності, право на свободу і особисту недоторканність, право на звернення до органів державної влади та органів місцевого самоврядування, право на житло, право на шлюб, право на судовий захист, право на професійну правничу допомогу тощо.

Щодо обмеження конституційних прав людини, то тут також вбачається за доцільне звернутися до практики Конституційного Суду України, який визнавав неконституційними ті закони, які надмірно обмежували конституційні права людини.

Рішенням Конституційного Суду України від 29 грудня 1999 року № 11-рп/1999 було захищено конституційне право людини на життя та визнано існування смертної кари як виду покарання - неконституційним. Зокрема, Суд дійшов висновку про те, що «Конституція України не містить будь-яких положень про можливість застосування смертної кари як винятку з положення частини першої статті 27 Конституції України про невіддільне право на життя кожної людини. Таким чином, смертну кару як вид покарання, передбачений у відповідних положеннях 
Права людини в Україні та у зарубіжних країнах:

проблеми теорії та нормативно-правової регламентації

Кримінального кодексу України, не можна вважати винятком з невіддільного права на життя кожної людини, закріпленого у Конституції України. Положення Кримінального кодексу України щодо застосування смертної кари як виду покарання повинні розглядатись як не передбачені Конституцією України обмеження невіддільного права на життя кожної людини і мають бути визнані такими, що не відповідають Конституції України (неконституційними)» [16].

Вирішуючи питання про конституційність у справі про призначення судом більш м'якого покарання, Конституційний Суд України рішенням від 2 листопада 2004 року № 15-рп/2004 визначив, що «правова держава, вважаючи покарання передусім виправним та превентивним засобом, має використовувати не надмірні, а лише необхідні і зумовлені метою заходи. Обмеження конституційних прав обвинуваченого повинно відповідати принципу пропорційності: інтереси забезпечення охорони прав i свобод людини i громадянина, власності, громадського порядку та безпеки тощо можуть виправдати правові обмеження прав і свобод тільки в разі адекватності соціально зумовленим цілям» [17].

Крім того, принагідно навести як приклад захисту від надмірного обмеження конституційних прав рішення Конституційного Суду України від 1 червня 2016 року № 2-рп/2016 (справа про судовий контроль за госпіталізацією недієздатних осіб до психіатричного закладу).

У вказаному рішенні Суд констатував, «обмеження щодо реалізації конституційних прав і свобод не можуть бути свавільними та несправедливими, вони мають встановлюватися виключно Конституцією i законами України, переслідувати легітимну мету, бути зумовленими суспільною необхідністю досягнення цієї мети, пропорційними та обгрунтованими, у разі обмеження конституційного права або свободи законодавець зобов'язаний запровадити таке правове регулювання, яке дасть можливість оптимально досягти легітимної мети з міні- 
мальним втручанням у реалізацію цього права або свободи і не порушувати сутнісний зміст такого права» [18].

Разом 3 тим не можна сказати, що практика конституційної юрисдикції $\epsilon$ настільки грунтовною відносно захисту конституційних прав людини, щоб у державі не було місця для прикладів надмірного втручання та обмеження таких прав.

На початку дослідження ми звертали увагу на те, що демократія, для якої $є$ цінністю права людини, не може відмежуватися від непередбачуваних викликів. Сьогодні таким глобальним викликом для сучасних демократій стала пандемія коронавірусної інфекції (COVID-19). Карантин було визнано форс-мажором, проте такі заходи межують на рівні допустимих меж для обмеження конституційних прав людини. Не маємо підстав робити далекоглядні висновки щодо пропорційності обмежувальних заходів у період карантину, але маємо можливість проаналізувати деякі аспекти цієї актуальної проблеми.

Загальний екскурс запровадження карантину в Україні можна описати таким чином: карантинні заходи на загальнодержавному рівні було запроваджено рішенням Кабінету Міністрів України, а також Указом Президента України, яким було затверджено Рішення національної безпеки та оборони України «Про невідкладні заходи щодо забезпечення національної безпеки в умовах спалаху гострої респіраторної хвороби COVID-19, спричиненої коронавірусом SARS-CoV-2» від 13 березня 2020 року. Також на виконання цих рішень органами державної влади, місцевого самоврядування, підприємствами, установами та організаціями, незалежно від форм власності, приймались додаткові рішення про запровадження карантинних обмежень на локальному рівні.

Загалом запроваджено обмеження стосовно переміщення групою осіб у кількості більше ніж дві особи; відвідування парків, скверів, зон відпочинку, лісопаркових та прибережних зон, крім вигулу домашніх тварин однією особою; перебування на вулицях без документів, що 
посвідчують особу, підтверджують громадянство чи іiі спеціальний статус і так далі.

У суспільстві відбулись дискусії щодо можливості запровадження обмежень на такому рівні, без запровадження надзвичайного стану в державі. До слова, на думку експертів ГО «Центру політико-правових реформ», обмежувальні заходи, які запроваджено в Україні в березні 2020 року, суттєво обмежують конституційні права і свободи людини і громадянина, а тому вони не можуть запроваджуватися поза межами легальних правових режимів, передбачених Конституцією України. Тому правовим режимом, у межах якого допустиме обмеження конституційних прав людини, $\epsilon$ надзвичайний стан. Надзвичайний стан може вводитися для боротьби 3 пандеміями, що створюють загрозу життю і здоров'ю значних верств населення, як на території всієї України, так і в окремих її місцевостях [19].

Крім того, експерти Харківської правозахисної групи також висловили пересторогу щодо доцільності та законності запровадження карантинних заходів в Україні. На думку цієї правозахисної організації, такого роду обмеження мали запроваджуватися в рамках введення надзвичайного стану. Зазначається, що епідемія COVID-19 $є$ тяжким випробуванням для України. Водночас, незважаючи на кризові явища у суспільстві, Україна має залишатися правовою та демократичною державою. Прийняття рішень органами державної влади поза межами їх повноважень, до яких, на їхню думку, належить і рішення Кабінету Міністрів України, є неприпустимим кроком до сваволі влади та хаосу у суспільстві [20].

Отже, держава зобов'язана належним чином реагувати на виклики такого масштабу, як протидія пандемії (COVID-19). Разом з тим від того, наскільки дії держави будуть правомірними, а запровадженні обмеження пропорційними, залежить рівень розвитку як демократії, так і гарантії та захисту прав людини. 
Очевидним $\epsilon$ також той факт, що у найближчому майбутньому виникнуть спори, пов'язані із захистом прав людини в умовах карантину. До прикладу, деякі держави (Албанія, Вірменія, Естонія, Грузія, Латвія, Північна Македонія, Республіка Молдова, Румунія, Сан-Марино, Сербія $\left.{ }^{1}\right)$ заявили про відступ від зобов'язань до Конвенції про захист прав людини i основоположних свобод 1950 року (на підставі статті 15 Конвенції) у зв'язку з пандемією COVID-19.

Понад це, на думку професора Центральноєвропейського університету Дж. МакБрайда, відступ від зобов'язань не звільнить держави від відповідальності за втручання у права і свободи. «Існують сумніви в тому, чи всі накладені обмеження вимагають того, щоб відступ від зобов'язань залишався сумісним з вимогами Конвенції, але $\epsilon$ й інші, які можуть стати необхідними, особливо якщо вони триватимуть протягом тривалого періоду» [21]. Разом $з$ тим не виключено, що до Європейського суду 3 прав людини надходитимуть скарги від заявників, які обгрунтовуватимуть порушення конвенційних прав державою в умовах карантинних обмежень.

\section{Висновки}

До змісту прав людини, окрім аксіологічних засад в умовах демократії, також слід віднести поділ їх на різні групи. В рамках цього дослідження увагу приділено конституційним правам людини. У правничій доктрині часто покликаються на права людини як конституційні, основні, фундаментальні тощо. Загалом названа градація прав людини $є$ рівнем одного порядку.

Комплексне розуміння функціонального призначення прав людини, яке може розкриватись у тому числі через відповідні функції, дає можливість навести фокус на

1 За даними офіційного веб-сайту Ради Європи станом на 24 квітня 2020 року: URL: https://www.coe.int/en/web/conventions/ full-list/-/conventions/webContent/62111354 
змістовні проблеми прав людини в сучасних умовах. Загальні підходи до розуміння прав людини 3 погляду практики їх реалізації не враховують кореневі проблеми цієї теми, особливо у правничих дослідженнях.

Окрему увагу слід приділяти межам для обмеження конституційних прав людини. Такі обмеження $\epsilon$ допустимими за умови відповідності їх стандартам, виробленим західною правничою доктриною 3 прав людини. Таким чином, рамками обмеження прав людини $\epsilon$ так званий «трискладовий тест» на пропорційність: 1) правовий закон; 2) легітимна мета; 3) обгрунтована необхідність обмеження в демократичному суспільстві.

\section{Список використаних джерел:}

1. Coronavirus disease (COVID-19) Pandemic. URL: https://www.who.int/emergencies/diseases/novelcoronavirus-2019 (Дата звернення 20.04.2020).

2. Timothy D. Snyder. "On Tyranny: Twenty Lessons from the Twentieth Century". 2017, 128 p.

3. Загальна теорія права : підручник / За заг. ред. М.I. Козюбри. Київ : Ваіте, 2015. 392 с.

4. Сатохіна Н.I. Обгрунтування прав людини: реконструкція проблеми. Вісник Національного університету «Юридична академія України імені Ярослава Мудрого». Серія: Філософія. 2016. № 1. С. 119-127.

5. Robert Alexy, Menschenrechte ohne Metaphysik?, in: DZPhil 52 (2004) S. 15-24.

6. Антонович М.М. Права людини за конституційним та міжнародним правом: порівняльний аспект. Наукові записки НаУКМА. Серія «Правничі науки». 2000. Т. 18: C. $16-21$.

7. Філософія прав людини / За редакції Ш. Госепата та Г. Ломана ; пер. 3 нім. О. Юдіна та Л. Доронічевої. Київ : Ніка-Центр, 2016. 320 с.

8. Basic Law For The Federal Republic of Germany. URL: http://www.codices.coe.int/NXT/gateway.dll?f=templates\&fn= default.htm (дата звернення 21.04.2020). 
9. Савчин М.В. Конституційне право України : підручник / відп. ред. проф., д.ю.н. М.О. Баймуратов. Київ : Правова єдність, 2009. 1008 с.

10. Hans D. Jaras Funktionen und Dimensionen der Grundrechte / Handbuch der Grundrechte in Deuschland und Europa. C.F. Muller, Verlagsgruppe Huthing Jehle Rehm GmbH, Heidelberg, Munchen, Landsberg, Berlin, 2006, S. 625-654.

11. Велика українська юридична енциклопедія : Т. 2 : Філософія права / редкол. : C.I. Максимов та ін. Харків : Право, 2017. 1128 с.

12. Размєтаєва Ю.С. Права людини як фундаментальна цінність громадянського суспільства : монографія. Харків : «Финарт», 2013.196 с.

13. Панкевич 0.3. Підстави обмежування прав людини: філософсько-правовий аспект. Вісник Національної академії правових наук України. 2016. № 3. С. 141-150.

14. Савчин М.В. Сучасні тенденції конституціоналізму у контексті глобалізації та правового плюралізму : монографія. Ужгород : РІК-У, 2018. 440 с.

15. Дахова I.I. Обмеження реалізації прав і свобод людини: конституційне регулювання та практика Європейського Суду з прав людини. Форум права. 2018. № 4. C. 17-25.

16. Рішення Конституційного Суду України у справі за конституційним поданням 51 народного депутата України щодо відповідності Конституції України (конституційності) положень статей 24, 58, 59, 60, 93, 190-1 Кримінального кодексу України в частині, що передбачає смертну кару як вид покарання (справа про смертну кару) від 29 грудня 1999 року № 11-рп/1999 URL: https://zakon.rada.gov.ua/laws/show/v011p710-99 (дата звернення 24.04.2020).

17. Рішення Конституційного Суду України у справі за конституційним поданням Верховного Суду України щодо відповідності Конституції України (конституційності) положень статті 69 Кримінального кодексу України (справа про призначення судом більш м'якого покарання) 
від 2 листопада 2004 року № 15-рп/2004 URL: https://zakon.rada.gov.ua/laws/show/v015p710-04 (дата звернення 24.04.2020).

18. Рішення Конституційного Суду України у справі за конституційним поданням Уповноваженого Верховної Ради України 3 прав людини щодо відповідності Конституції України (конституційності) положенням третього речення частини першої статті 13 Закону України «Про психіатричну допомогу» (справа про судовий контроль за госпіталізацією недієздатних осіб до психіатричного закладу) від 1 червня 2016 року № 2-рп/2016 URL: https://zakon.rada.gov.ua/laws/show/ v002p 710-16 (дата звернення 24.04.2020).

19. Суттєві обмеження прав i свобод людини i громадянина $\epsilon$ неконституційними без введення надзвичайного стану / веб-сайт ГО «Центр політикоправових реформ» URL: https://pravo.org.ua/ua/news/ 20874326-suttevi-obmegeennya-prav-i-svobod-lyudini-igromadyanina-e-nekonstitutsiynimi-bez-vvedennya-nadzvichaynogo-stanu?fbclid=IwAR3KZD-qxIFL3yuWMQIOIUYp9_aXLe FuzNz2al6Fe2b8bR1MSU0Amf2_1oM (дата звернення 24.04.2020).

20. Висновок Харківської правозахисної групи щодо доцільності та законності запровадження карантинних заходів відповідно до Постанови Кабінету міністрів України № 255 від 2 квітня 2020 року / веб-сайт Харківської правозахисної групи URL: http://khpg.org/ index.php?id=1586221405 (дата звернення 24.04.2020).

21. У якій мірі боротьба 3 коронавірусною інфекцією допускає обмеження прав людини / стаття Джеремі МакБрайда на веб-сайті «Закон і Бізнес» URL: https://zib.com.ua/ua/142070-covid-19_i_konvenciya_u_yakiy_ miri_borotba_z_koronavirusnoyu.html (дата звернення 23.04.2020). 
DOI https://doi.org/10.36059/978-966-397-210-7/67-90

\section{Волощук О. T.,}

кандидат юридичних наук, доцент, завідувач кафедри міжнародного та митного права

Чернівецького юридичного інституту

Національного університету «Одеська юридична академія», м. Чернівці

Колесник В. Ю., асистент кафедри міжнародного та митного права

Чернівецького юридичного інституту Національного університету «Одеська юридична академія», м. Чернівиі

\section{ПРАВО НА ОСВІТУ У XXI СТОЛІТТІ: ПОНЯТТЯ, СТАНДАРТИ ТА ПРОБЛЕМИ РЕАЛІЗАЦІЇ}

Анотація. Підрозділ присвячений дослідженню права на освіту як одного із фундаментальних прав людини. При цьому автори визначають місце права на освіту у системі прав людини та роблять висновок про комплексний характер цього права, що унеможливлює віднесення його до конкретної групи прав людини. Особливість підрозділу полягає у проведенні аналізу міжнародних та національних нормативно-правових стандартів щодо закріплення права на освіту, зі змісту яких виділяються компоненти права на освіту: доступність, загальність, якість. Автори наголошують на існуванні позитивних обов'язків держави поважати, захищати і реалізовувати право на освіту. Результати дослідження свідчать про те, що як міжнародна спільнота, так і Україна використали всі можливі способи регламентації права на освіту. Втім, в умовах сучасного швидкоплинного світу це виявляється недостатнім для забезпечення усіх правом на освіту. 


\section{Вступ}

Як справедливо останнім часом відмічають вчені та спостерігачі, ми живемо у дуже «турбулентний» час, при цьому, немає жодного значення про що йде мова: технології, глобальне врядування, світові фінансові ринки, зміни клімату чи права людини. Куди б ми не звернулися, ми стикаємося із мінливістю, невизначеністю, складністю та неоднозначністю. Не винятком $\epsilon$ і сфера освіти, де відбулися та продовжують відбуватись швидкі зміни як всередині, так і зовні традиційних освітніх систем. До прикладу запровадження дистанційної освіти та міжнародної мобільності зробила кордони між державами уявними, однак при цьому питання взаємного визнання дипломів залишилось відкритим, а потреба «навчитися вчитися» $\epsilon$ більш актуальною, ніж будь-коли у світлі швидких змін по всьому світу.

Тому не дивним і не випадковим $є$ факт, що саме освіта покликана відігравати важливу роль для людського, соціального та економічного розвитку і $\epsilon$ ключовим елементом для досягнення стійкого миру та сталого розвитку. Це потужний інструмент розвитку всього потенціалу кожного та забезпечення гідності людини, а також сприяння індивідуальному та колективному добробуту. Водночас вона не є чарівними ключем, що відкриває двері в ідеальний у усіх відношеннях світ. Освіта - один із основних засобів утвердження більш глибокої і гармонійної форми розвитку людства, яка дозволить боротися 3 убогістю, відчуженням, неграмотністю, пригніченням і війною. При цьому сьогодні освіта залишається розкішшю (недоступним правом) для мільйонів дітей у всьому світі: більше 72 мільйонів дітей не навчаються в школі, а 759 мільйонів дорослих неграмотні і не мають достатніх навиків та знань, необхідних для поліпшення як своїх життєвих умов, так і майбутнього своїх дітей. 
Все це своєю чергою зумовлює надання особливого значення питанню щодо забезпечення та захисту права на освіту у країнах світу та Україні зокрема. Нові вектори розвитку країн (із наданням освіті важливого значення) своєю чергою посилюють необхідність дослідження права на освіту як у міжнародній, так і в національній площині. Попри наявний науковий доробок, присвячений вивченню права на освіту, питання щодо реалізації та захисту цього права потребують подальшого змістовного аналізу 3 урахуванням як положень міжнародного, так i національного права.

\section{1. Право на освіту в системі прав людини}

«Освіта - це весь процес суспільного життя, за допомогою якого окремі індивіди та соціальні групи в рамках i для блага національного та міжнародного співтовариства свідомо вчаться розвивати свої таланти, здібності і знання, причому цей процес не обмежується жодною конкретною діяльністю» [33]. Саме таке визначення пропонує флагманська організація у питаннях освіти - Організація Об'єднаних Націй із питань освіти, науки і культури (далі - ЮНЕСКО).

Загальна декларація прав людини своєю чергою стверджує, що освіта $\epsilon$ основним (фундаментальним) правом кожної людини [6]. Дійсно, право на освіту можна охарактеризувати як «право на розширення прав i можливостей». Воно дає людині більш ефективний контроль над перебігом свого життя i, зокрема, контроль над політикою і діями держави щодо самої людини. Іншими словами, реалізація права на освіту дозволяє людині користуватися перевагами інших прав.

Так, практична реалізація багатьох громадянських i політичних прав, таких як свобода слова, свобода вираження поглядів, право обирати і бути обраним, а також багатьох інших, залежить певною мірою від мінімального рівня освіти. Скористатися низкою 
економічних, соціальних і культурних прав, таких як право на вільний вибір роботи, рівну оплату за аналогічну працю, користування результатами науково-технічного прогресу і доступ до вищої освіти на основі здібностей, можливо головним чином тільки після отримання мінімального рівня освіти.

Те ж саме справедливо і щодо права на участь у культурному житті. Для етнічних і мовних меншин право на освіту є важливим засобом збереження і зміцнення своєї культурної самобутності. Освіта може сприяти (хоча і не гарантує) розумінню, терпимості, повазі і дружбі між народами, етнічними або релігійними групами і може допомогти створенню універсальної культури прав людини [20].

Із урахуванням цього можна твердити, що право на освіту є інтегральним правом, яке, нехай і різною мірою, але може бути віднесено до різних груп прав і свобод людини - соціальних, культурних, громадянських (особистих) i, тим самим, може мати різний зміст.

Відмітимо, що наразі у науковій спільноті немає одностайності щодо визначення місця права на освіту в системі прав людини і громадянина. Систематизувавши погляди вчених $[1 ; 17 ; 25 ; 27]$, можна виокремити декілька позицій, серед яких право на освіту відносять до: 1) культурних прав; 2) одночасно до культурних i соціальних прав; 3) соціально-економічних прав; 4) системи соціальних, економічних і культурних прав.

На наше переконання, права людини утворюють єдину цілісну систему, в якій усі елементи взаємопов'язані та взаємозалежні, тому віднесення права на освіту до конкретної групи прав людини $є$ хибним, адже межа, яка існує між групами прав людини, $\epsilon$ умовною. 3 огляду на це право на освіту необхідно розглядати з різних поглядів.

Так, право на освіту $є$ політичним правом, адже воно реалізується через освітню політику держави, яка являє собою різноманітну діяльність держави щодо забезпечення функціонування та розвитку національної 
системи освіти, а також діяльність держави у питаннях міжнародної освітньої кооперації.

Право на освіту $є$ і громадянським (особистим) правом людини, оскільки воно реалізується нею (людиною) самостійно, на власний розсуд, після, однак, виконання загальногромадянського (соціального) обов'язку здобути повну загальну середню освіту. Адже людину після здобуття загальної середньої освіти ніхто не примушує і не може примусити в обов'язковому порядку продовжувати своє навчання у закладах вищої освіти. Держава гарантує не обов'язок, а можливість вибору для індивіда: де, як та коли здобувати нові навички.

Право на освіту як соціальне право людини передбачає формування необхідних передумов для розвитку як окремого індивіда, так і всього суспільства. Від рівня освіченості безпосередньо залежить місце людини в соціумі і значною мірою її суспільний статус. Крім того, право на освіту як соціальне право передбачає створення системи державних гарантій отримання освіти кожною людиною, яка виступає найважливішою умовою її успішної соціалізації.

Право на освіту є одночасно і культурним правом. Адже саме через освіту i за допомогою освіти людина долучається до різних аспектів глобальної культури людства і національної культури зокрема. Саме освіта $€$ визначальним фактором формування у людини їі особистісної громадянської, політичної, правової та моральної культури.

I нарешті, право на освіту як економічне право, характеризується тим, що освіту можна розглядати як відокремлену галузь нематеріального виробництва, соціальну сферу і одночасно об'єкт економічних відносин суспільне благо і інтелектуальний товар, який задовольняє певні суспільні потреби і може продаватися як персоніфікований капітал [15, с. 60-61].

Отже, виняткове значення освіти зумовлюється насамперед тим, що в сучасному світі рівень і якість 
Права людини в Україні та у зарубіжних країнах:

проблеми теорії та нормативно-правової регламентації

освіченості населення стає базою, що визначає ступінь розвитку суспільства, економічне і соціальне становище держави, благополуччя їі громадян. А право на освіту $\epsilon$ одним з найбільш істотних конституційних прав людини, що створює передумову для розвитку як її особистісно, так і всього суспільства. Воно гарантується конституційними актами всіх сучасних демократичних держав і нормами міжнародного права.

На цей час у демократичних державах право на освіту в широкому сенсі включає, звичайно, цілий комплекс прав, серед яких: право на здобуття безкоштовної початкової і середньої освіти в державних і муніципальних школах і деяких інших закладах освіти; загальнодоступність освіти; право на вибір форми навчання; свобода викладання; право на заснування приватних закладів освіти. Багато конституцій підкріплюють право на освіту обов'язком батьків (або осіб, які їх замінюють) забезпечити отримання дітьми початкової (або загальної основної) освіти. Цей перелік не $\epsilon$ вичерпаним та доповнюється вимогою якості освіти, яка зазвичай безпосередньо в текстах правових актів прямо не згадується, однак слідує із самого права на освіту як запоруки подальшого успіху людини.

В Україні зміст права на освіту слідує із положень Конституції нашої держави, ст. 53 якої передбачає право кожного на освіту, включаючи обов'язковість повної загальної середньої освіти, необхідність забезпечення державою доступності та безоплатності освіти, сприяння розвитку освіти на усіх рівнях та різних форм навчання [14].

Таким чином, право на освіту $є$ і конституційним правом, що свідчить про його виняткове значення. Водночас воно $€ \mathrm{i}$ загальним правом, оскільки поширюється на всіх без винятку громадян держави, іноземних громадян та осіб без громадянства, які проживають на території держави на законних підставах незалежно від віку. Право на освіту передбачає доступність освіти для кожного, що виражається у свободі здобувати як дошкільну, загальну середню, так і професійно-технічну і фундаментальну вищу освіту 
відповідно до власних бажань і можливостей. У цьому плані доступність освіти органічно пов'язана зі загальністю відповідного права. Водночас доступність забезпечується i через безоплатність освіти.

Відмітимо, що доступність освіти $€$ основоположним принципом міжнародного освітнього права, відповідно до якого держави як мінімум зобов'язані забезпечити реалізацію права на освіту за допомогою гарантування рівного доступу до закладів освіти усім без винятку на засадах рівності і недискримінації. Позитивний обов'язок забезпечити рівний доступ до закладів освіти передбачає як фізичний (можливість здобувати освіту літнім людям та інвалідам), так і конструктивний доступ (усування бар'єрів, наприклад, шляхом викорінення стереотипних понять ролі чоловіка і жінки з підручників та освітніх структур, що закріплено в ст. 10 Конвенції про ліквідацію всіх форм дискримінації щодо жінок 1979 року).

Таким чином, право на освіту - це і позитивне право, адже воно породжує своїм існуванням позитивні обов'язки держави - поважати, захищати і реалізовувати право на освіту. Так, зобов'язання «поважати» вимагає від держав утримуватися від вжиття заходів, які прямо або побічно ускладнюють або перешкоджають здійсненню права на освіту. Держави повинні, зокрема, поважати свободу батьків у виборі приватних або державних закладів освіти для навчання своїх дітей і право забезпечувати релігійне і моральне виховання своїх дітей відповідно до власних переконань. Слід з рівною повагою ставитись до навчання хлопчиків і дівчаток, як і представників всіх релігійних, етнічних і мовних груп. Зобов'язання «захищати» вимагає від держав приймати законодавчі, адміністративні та інші заходи для недопущення посягань з боку третіх осіб на здійснення права на освіту або дискримінацію у питаннях освіти. Зобов'язання «здійснювати» вимагає від держав прийняття відповідних законодавчих, адміністративних, бюджетних, судових, стимулюючих та інших заходів, що сприятимуть і допомагатимуть окремим особам і громадам 
користуватися правом на освіту. Кращим прикладом для ілюстрації цього обов'язку є ст. 14 Міжнародного пакту про економічні, соціальні і культурні права, згідно з якою нові держави-учасниці, які ще не встановили обов'язкову безкоштовну початкову освіту, зобов'язані «розробити i прийняти докладний план заходів для поступового впровадження в життя протягом розумного строку ... принципу обов'язкової безкоштовної загальної освіти».

\section{2. Міжнародні та національні стандарти права на освіту}

Стандарти права на освіту визначаються в нормативноправових актах різного рівня, серед яких як норми внутрішнього права держави, так і міжнародного права.

Серед числа відомих та досить вагомих міжнародних джерел закріплення фундаментальних прав і свобод людини та громадянина $\epsilon$ згадана вище Загальна декларація прав людини 1948 року, яку у світовій практиці не можна не відмітити як першооснову вказаного вище явища. Так, у Декларації регламентовано право кожної людини на освіту (ст. 26), що сприятиме соціальному прогресові і поліпшенню умов життя, розвиткові дружніх відносин між народами та загальному миру (преамбула) [6]. Це закріплення права на освіту як фундаментального права людини стало для світової спільноти великим кроком вперед. Відтоді право на освіту отримало широке визнання та подальший розвиток у ряді міжнародних нормативних документів, розроблених під егідою Організації Об'єднаних Націй (далі - 00H) та ії спеціалізованих установ.

Так, для забезпечення впровадження в життя положення Декларації щодо забезпечення правом на освіту усіх без винятку під егідою ЮНЕСКО у 1960 році прийнято Конвенцію про боротьбу з дискримінацією у галузі освіти. У зв'язку із зазначеним нормативним актом стає зрозуміло, що обмеження осіб за ознаками раси, кольору шкіри, статі, релігійними та політичними поглядами, національним чи 
соціальним походженням, економічним становищем та іншими особистісними ознаками $\epsilon$ негативним, деструктивним суспільним явищем, що перешкоджає утвердженню головних завдань правової держави. В суспільстві таке явище іменується дискримінацією, і його можливі наслідки вже неодноразово дивували та обурювали світову спільноту. Тому, проводячи аналіз положень зазначеної Конвенції, можна стверджувати, що основна іï мета полягає у «викоріненні» усіх можливих проявів дискримінації в освітньому процесі та забезпеченні рівного доступу до освіти кожної особи [8].

Досить змістовно розкриває питання права на освіту Міжнародний пакт про економічні, соціальні і культурні права 1966 року, який, підтверджуючи право кожної людини на освіту, визнає, що освіта повинна бути спрямована на повний розвиток людської особистості і усвідомлення ії гідності та повинна зміцнювати повагу до прав людини i основних свобод. Освіта також повинна дати можливість усім бути корисними учасниками вільного суспільства, сприяти взаєморозумінню, терпимості і дружбі між усіма націями i всіма расовими, етнічними та релігійними групами і сприяти роботі ООН з підтримання миру (ст.13). Разом з цим Пакт встановив обов'язки для держав щодо забезпечення реалізації права на освіту тощо [18].

Наступним важливим документом, який заслуговує на увагу у контексті забезпечення права на освіту, стала Конвенція про права дитини 1989 року, яка встановлює цілі освіти дитини, яка повинна бути спрямована на розвиток особистості, талантів, розумових і фізичних здібностей у найповнішому обсязі, а також виховання поваги до прав людини і основних свобод, виховання поваги до батьків дитини, ï культурної самобутності, мови і цінностей, національних цінностей країни, в якій дитина проживає, країни іiї походження та до цивілізацій, відмінних від їі власної. Освіта дитини має бути також спрямована на підготовку до свідомого життя у вільному суспільстві в дусі розуміння, миру, терпимості, 
Права людини в Україні та у зарубіжних країнах:

проблеми теорії та нормативно-правової регламентації

рівноправності чоловіків і жінок та дружби між усіма народами, етнічними, національними і релігійними групами, а також особами з числа корінного населення. Крім того, освіта повинна бути спрямована на виховання поваги до навколишнього середовища.

Конвенція також закріплює право окремих осіб і органів створювати заклади освіти та здійснювати керівництво ними за умови постійного додержання мінімальних стандартів i норм, встановлюваних державами 3 урахуванням їх міжнародних зобов'язань під час здійснення освітньої діяльності (ст. 29). Також державиучасниці заохочують і розвивають міжнародне співробітництво з питань, що стосуються освіти, зокрема, з метою сприяння ліквідації невігластва і неписьменності в усьому світі та полегшення доступу до науково-технічних знань і сучасних методів навчання (ст. 28) [10].

Право на освіту було підтверджено також в інших актах, в тому числі міжнародного м'якого права, що охоплюють конкретні групи (жінок та дівчат [9; 29], інвалідів [11], мігрантів [16], біженців [12], корінні народи [13] тощо) та контексти (освіта під час збройних конфліктів [31; 35]).

Зазначимо, що використання актів м'якого права (англ. soft law), тобто тих, що не $\epsilon$ юридично обов'язковими у врегулюванні міжнародних відносин, є звичною практикою, що пов'язано насамперед із такими намірами: підвищити продуктивність зовнішніх зносин; нівелювати труднощі у процесі перемовин та кінцевих домовленостей; посилити межі дискреційних повноважень сторін під час виконання домовленостей. Зрештою, незобов'язальні домовленості $\epsilon$ більш придатними для політично чутливих сфер або тих, що мають змінний характер, до яких належить і освіта.

Прикладами таких актів можуть слугувати рекомендації ЮНЕСКО, які стосуються освіти, в тому числі, права на освіту. Загалом із моменту заснування ЮНЕСКО підготовлено та прийнято вісім рекомендацій [30], провідне місце серед яких, на нашу думку, слід надати Рекомендації про боротьбу із дискримінацією у сфері 
освіти 1960 року [32] та Рекомендації стосовно освіти для міжнародного порозуміння, співробітництва і миру, освіти в галузі прав і основних свобод людини 1974 року [33].

Право на освіту також включене до різних регіональних договорів. Безумовно, першопроходьцем в цьому аспекті став регіон Європи. Так, згідно зі ст. 2 Протоколу № 1 до Конвенції про захист прав людини і основних свобод 1950 року, нікому не може бути відмовлено в праві на освіту. Держава своєю чергою поважає право батьків забезпечувати освіту і навчання відповідно до їхніх релігійних і світоглядних переконань. На перший погляд може здатись, що гарантії цієї статті є обмеженими, однак таке формулювання створює значно більше можливостей для інтерпретації положень цієї статті Європейським судом з прав людини. Так, зокрема, оскільки право на освіту викладено в ст. 2 в негативному формулюванні («Нікому не може бути відмовлено в праві на освіту»), державиучасниці самостійно визначають характер і структуру своєї освітньої системи; в демократичному суспільстві право на освіту відіграє настільки фундаментальну роль, що обмежувальне тлумачення наведеного вище положення Протоколу № 1 суперечило б його предмету і меті; у зміст права на освіту входять, зокрема: доступ до наявних закладів освіти, передача знань та інтелектуальний розвиток, можливість користуватися отриманою освітою за допомогою її офіційного визнання державою з видачею документів про освіту; право на освіту поширюється на різні рівні освіти, в тому числі початкову шкільну, повну середню, вищу і фахову. Таким чином, бенефіціарами цієї статті виступають не тільки діти, а й дорослі, тобто будьякі особи, які бажають скористатись правом на освіту; держави-учасниці несуть відповідальність за функціонування як державних, так і приватних закладів освіти та інше [4].

Певні елементи права на освіту регламентуються і в інших документах Ради Європи. Так, у переглянутій Європейській соціальній хартії 1996 року передбачаються 
Права людини в Україні та у зарубіжних країнах:

проблеми теорії та нормативно-правової регламентації

зобов'язання держав-учасниць щодо права певних соціальних груп на освіту, зокрема, професійну (ст. 10) [5]. Також особливу увагу приділено забезпеченню і захисту прав осіб, які належать до національних, етнічних, релігійних та мовних меншин. Так, Рамковою конвенцією про захист національних меншин 1995 року передбачено право на вивчення мови своєї меншини (ст. 14) та право на заснування власних приватних закладів освіти (ст. 13) [24].

Окрім згаданих міжнародних нормативних актів, на увагу заслуговує Спільна декларація міністрів освіти Європи «Європейський простір у сфері вищої освіти» 1999 року, положення якої продемонстрували розуміння європейською спільнотою значущості освіти, зокрема вищої, та усвідомлення важливості права на освіту. Підтвердженням цієї тези може слугувати положення цієї декларації про те, що загальновизнаним $\epsilon$ першочергове значення освіти та освітнього співробітництва для розвитку і зміцнення стабільних, мирних і демократичних суспільств [26].

Осторонь освітньої галузі не залишається i Європейський Союз, який у своїй Хартії про основні права 2000 року, яка за своїм характером $\epsilon$ унікальним документом (адже відмовилась від традиційного поділу прав людини на громадянські, політичні, економічні, соціальні та культурні, а натомість розглядає права людини через цінності, на захист яких вони спрямовані, що підтверджується відповідними назвами розділів цього документу: «Гідність», «Свободи», «Рівність», «Солідарність»), закріплює право на освіту та гарантує доступ кожній людині до освіти, а також до професійної підготовки та підвищення кваліфікації. Це право включає можливість безоплатного здобуття обов'язкової освіти та право батьків забезпечувати своїм дітям навчання i виховання відповідно до їх релігійних, філософських i педагогічних переконань, відповідно до національного законодавства, що регламентують їх здійснення (ст. 14 розділ «Свободи») [28]. 
Міжнародні стандарти права на освіту не обмежуються вищеперерахованими документами, а включають і інші, що прямо чи опосередковано охоплюють питання регламентації права на освіту. Важливо те, що Україна як демократична держава визнала положення зазначених вище конвенцій, а тому, відповідно до ст. 9 Конституції нашої держави, вони стали частиною національного законодавства.

Національні стандарти права на освіту передбачені цілою низкою нормативно-правових актів, які деталізують специфіку освітнього процесу та визначають механізм реалізації права на освіту. Так, важливим кроком у врегулюванні освітніх питань стало прийняття у 2017 році нового Закону України «Про освіту», який досить детально розкриває питання права на освіту, що включає право на доступну, якісну та безоплатну освіту (у випадках, передбачених законодавством). При цьому ніхто не може бути обмежений у праві на здобуття освіти на різних рівнях, у різних формах і різних видів. Прогресивним положенням $\epsilon$ закріплення принципу «навчання протягом життя» (англ. lifelong learning) (ст. 3). Реалізація цього права забезпечується державою шляхом розвитку освіти на усіх іï рівнях та їі безоплатність відповідно до стандартів освіти (ст. 4) [22].

Також питання щодо права на освіту знаходить своє відображення і в інших законодавчих актах - законах України «Про вищу освіту» 2014 року [21], «Про повну загальну середню освіту» 2020 року [23] та інших. Так, наприклад, Законом України «Про вищу освіту» закріплено, що кожен має право на вищу освіту на умовах принципу паритетності (рівності, недискримінації). Громадяни України мають право на здобуття вищої освіти на безоплатній основі в державних і комунальних закладах вищої освіти на конкурсній основі тощо (ст. 4) [21].

Таким чином, можна констатувати, що в Україні $\epsilon$ необхідна правова база, яка дає змогу державі належним чином забезпечувати право громадян на здобуття освіти 
Права людини в Україні та у зарубіжних країнах:

проблеми теорії та нормативно-правової регламентації

на рівні встановлених світових стандартів. Однак забезпечення виконання усіх компонентів права на освіту в нашій державі $є$ вкрай низьким.

\section{3. Сучасні виклики під час реалізації права на освіту}

Поряд із встановленням стандартів права на освіту, сформовані механізми забезпечення та захисту права на освіту, які можна поділити на дві групи. Першу групу складають внутрішньодержавні (національні) механізми, в яку входять відомчі контрольні органи (ліцензування, атестації, інспектування) i правоохоронні органи, які зобов'язані запобігати фактам порушення права на освіту. Другу групу складають міжнародні механізми забезпечення і захисту права на освіту, такі як Рада з прав людини та Комітет з прав людини. Крім того, ЮНЕСКО взяла на себе зобов'язання захищати мир у світі через освіту, природні та соціальні науки та культуру. Правозахисними спостерігачами $\epsilon$ також міжнародні неурядові організації з прав людини, такі як Amnesty International, Human Rights Watch, Міжнародне бюро з прав людини та Міжнародна федерація прав людини. Ці організації стежать за проблемами та проблемними ситуаціями по всьому світу та пропагують свою думку.

Однак головним представником збереження права на освіту $\epsilon$ Міжнародний фонд надзвичайних ситуацій у справах дітей (ЮНІСЕФ), створений Генеральною Асамблеєю ООН у 1946 році. Метою організації є захист прав дітей, безпосередньо діючи в проблемних сферах і шляхом організації програм розвитку. Центральною частиною цієї організації $\epsilon$ освіта. Відповідно до своїх цілей ЮНІСЕФ працює у всьому світі, щоб підтримати якісне навчання для кожної дівчини та хлопчика, у кожному куточку світу.

Однак, незважаючи на наявність такого розгалуженого механізму захисту права на освіту, про повноцінне його забезпечення у кожній країні світу говорити ще зарано.

Так, у 2000 році на Всесвітньому освітньому форумі в Дакарі була представлена та затверджена програма «Освіта для всіх» (англ. Education for All), яка виступає «глобальним 
зобов'язанням» 164-х країн забезпечити якісну базову освіту для всіх дітей, молоді та дорослих. У рамках програми було визначено перші шість цілей, розраховані на 15 років, серед яких: розширення та вдосконалення системи комплексного виховання та освіти в ранньому віці, особливо для найбільш вразливих та малозабезпечених дітей; забезпечення доступу до цілком безкоштовної та обов'язкової початкової освіти, особливо для дітей, що знаходяться у складних умовах, та тих, хто належать до етнічних меншин; забезпечення рівноправного доступу молоді та дорослих до відповідних навчальних та інших програм, що забезпечуватимуть розвиток людських навиків; підвищення рівня грамотності серед дорослих не менше ніж на 50\% та забезпечення рівного доступу до базової та безперервної освіти для всіх дорослих; усунення гендерних диспропорцій у початковій та середній освіті та досягнення гендерної рівності в освіті; поліпшення всіх аспектів якості освіти [36]. Також було представлено дванадцять стратегій для досягнення цих цілей.

Загалом вищевказані цілі сприяли глобальному досягненню Цілей розвитку тисячоліття 00Н, прийнятих того ж року, серед яких дві цілі безпосередньо стосувалися освіти: забезпечення загальної початкової освіти (Ціль № 2) та сприяння гендерній рівності у сфері освіти на усіх її рівнях, в рамках викорінення гендерної дискримінації загалом (Ціль № 3) [3]. Однак і інші цілі перебували у прямій залежності від інвестицій в освіту. Основним координатором цих цілей та забезпеченням права на освіту виступала ЮНЕСКО, яка за допомогою широкого партнерства із урядами країн, багатосторонніми агенціями та агенціями із розвитку, громадянським суспільством та приватним сектором підтримувала держави у досягненні високих результатів.

Додатково, із метою прискорення прогресу цілей щодо освіти у 2002 році, було започатковано ще одне унікальне партнерство - «Освіта для всіх - Швидкий шлях ініціативи», яке із 2011 року відоме як «Глобальне 
партнерство заради освіти» (англ. Global Partnership for Education), ідея якого полягає передусім у стимулюванні та наданні допомоги, ресурсів і технічної підтримки щодо впровадження національних освітніх реформ для забезпечення універсальності початкової освіти у країнах, що розвиваються [37]. Наразі ці ініціативи підтримуються 189-ма країнами світу та цілим рядом міжнародних організацій.

Однак і ця ініціатива була не в змозі забезпечити досягнення бажаних цілей державами та забезпечення права на освіту. Так, із моменту встановлення цілей опубліковано одинадцять проміжних та один заключний незалежні звіти щодо здобутків у досягненні бажаних цілей [34]. Аналізуючи фінальний звіт 2015 року, можна констатувати, що загалом країни світу досягли суттєвого прогресу, однак, незважаючи на зусилля урядів, громадськості та міжнародної спільноти, світ поки ще не досяг цілей освіти для всіх та не забезпечив загальне право на освіту. До здобутків можна віднести скорочення майже удвічі кількості дітей та підлітків, що не відвідують школу; активізація роботи щодо забезпечення гендерного паритету особливо щодо початкової освіти, тоді як гендерні диспропорції продовжують зберігатись у кожній третій країні, щодо якої є відповідні дані; посилення зусиль із питань вимірювання результатів навчання шляхом проведення національних і міжнародних оцінок успішності учнів, використовуючи їх для забезпечення того, щоб всі діти отримували високоякісну освіту, та інше.

Водночас, попри значні досягнення, моніторинг вказує і на досить тривожну картину. Насамперед йдеться про приблизно 58 мільйонів дітей, що залишаються поза стінами шкіл, і близько 100 мільйонів дітей, які позбавлені можливості отримати закінчену початкову освіту. Також посилилась нерівність в освіті, причому найважчий тягар лягає на плечі найбідніших і знедолених верств населення. Порівняно із більш забезпеченими, у дітей з найбідніших верств населення в чотири рази вища вірогідність не піти в 
початкову школу і в п’ять разів вища вірогідність не закінчити іï. Також серйозною перешкодою на шляху отримання освіти залишаються збройні конфлікти, враховуючи той факт, що в зонах конфлікту проживає значна і все більша частина дітей, які не відвідують школу. Загалом низька якість навчання на початковому рівні веде до того, що мільйони дітей як і раніше виходять зі стін школи, так і не опанувавши початкові навики (грамотності, математики). Навіть більше, освіта, як і раніше, фінансується недостатньою мірою. Велика кількість країн збільшили свої витрати на освіту, однак лише деякі з них відводять їй пріоритетне місце в своїх бюджетах [2].

3 огляду на це, усвідомлюючи неможливість досягнення цілей та необхідність їх кореляції на Всесвітньому освітньому форумі, що мав місце в Інчхоні (Корея) 19-22 травня 2015 року, було представлено «Нове бачення освіти на період до 2030 року» (англ. Towards 2030: A new vision for education), яким визнано важливу роль освіти як основної рушійної сили для розвитку [7].

Своєю чергою у вересні 2015 року Резолюцією Генеральної асамблеї ООН було представлено нову глобальну, амбіційну програму розвитку - «Перетворення нашого світу: Порядок денний у сфері сталого розвитку на період до 2030 року» (англ. "Transforming our world: the 2030 Agenda for Sustainable Development"), спрямовану на викорінення бідності із визначенням відповідних цілей, що прийшли на зміну попереднім. Серед цілей $\epsilon$ та, яка прямо стосується освіти (Ціль № 4) - «Якісна освіта: Забезпечення інклюзивної та рівноправної якісної освіти і формування можливостей усім для навчання протягом життя» (англ. Quality Education: Ensure inclusive and equitable quality education and promote lifelong learning opportunities for all), яка встановлює сім завдань, які мають очікувані результати, та три способи їх реалізації. Так, встановлено намір забезпечити: усунення гендерних диспропорцій в освіті та забезпечення рівного доступу до всіх рівнів освіти та професійної підготовки уразливих груп, включаючи 
людей 3 інвалідністю, корінних народів та дітей у вразливих ситуаціях; якісний дитячий розвиток, догляд та доступ до дошкільної освіти; універсальну, повністю безкоштовну початкову та середню освіту із формуванням якісних відповідних базових навиків; рівний доступ до якісної професійно-технічної та вищої освіти із формуванням відповідних навиків для працевлаштування; усю молодь та значну частину дорослого населення забезпечити вміннями грамотності та навиками рахівництва; щоб усі учні отримали знання, що сприятимуть сталому розвитку, зокрема, щодо сталого способу життя, прав людини, рівності між чоловіками та жінками, пропаганді миру та ненасильства, глобального громадянства та визнання культурного різноманіття та внеску культури у стійкий розвиток.

Імплементаційними засобами своєю чергою передбачено: створення та вдосконалення закладів освіти, що враховуватимуть інтереси дітей, особливі потреби інвалідів та гендерні аспекти, і забезпечать безпечне, ефективне, позбавлене насильства і соціальних бар'єрів навчальне середовище для всіх; збільшення до 2020 року кількості стипендій, наданих країнам, що розвиваються, першочергово найменш розвиненим та малим острівним державам і країнам Африки, для здобуття вищої освіти, включаючи професійно-технічну освіту і навчання інформаційно-комунікаційним технологіям, технічні, інженерні та наукові програми в розвинених країнах та інших країнах, що розвиваються; збільшення до 2030 року числа кваліфікованих вчителів, в тому числі за допомогою міжнародної співпраці у підготовці вчителів 3 найменш розвинених країн [19].

У листопаді того ж року було презентовано деталізовану дорожню карту для виконання Цілі № 4, призначену надати країнам практичне керівництво у питанні здійснення порядку денного в сфері освіти на період до 2030 року, Рамкову програму дій «Освіта - 2030», що стала результатом безпрецедентного консультативного процесу, спрямованого на мобілізацію всіх 
зацікавлених сторін для досягнення нових глобальних цілей і завдань у галузі освіти. Дії Рамок пропонують можливі шляхи здійснення, координації, фінансування та перегляду порядку денного «Освіта-2030» на всесвітньому, регіональному та національному рівнях 3 тим, щоб забезпечити всіх рівними можливостями реалізації права на освіту. Поряд із цим, на основі доробку вже наявних міжнародних угод та актів із питань освіти сформульовано чотири основні принципи плану дій, а саме: право на освіту (обов'язкову, безкоштовну та якісну) як ключове право людини, що розширює ії можливості; розгляд освіти як суспільного блага, відповідальність за яке покладається на держави; необхідність формування можливостей дорослому населенню для навчання протягом життя та визначення пріоритету за гендерною рівністю [7].

Втім, незважаючи на існування деталізованих планів дій щодо забезпечення усіх правом на освіту, світ продовжує знаходитись перед викликами. Серед основних проблем можна виділити такі: прогалини у законодавстві щодо забезпечення безкоштовної та обов'язкової освіти для всіх (менше 1 з 5 країн законодавчо закріпили таке право); нерівності та дискримінація в освіті (наприклад, у південно-сахарській африканській школі на 100 дітей із заможних родин лише 65 дітей із вразливих груп населення); міграція та переміщення, в тому числі, у зв'язку із збройними конфліктами (до прикладу, у 2018 році 3,5 мільйона біженців шкільного віку жодного дня не відвідували школу); приватизація та ії вплив на право на освіту (державам необхідно досягти балансу між свободою освіти та забезпеченням кожного якісною освітою); недостатнє фінансування освіти, хоч держав закликають виділяти на освіту щонайменше 4-6\% ВВП; неякісна підготовка педагогів; наявність чітких планів дій держав щодо забезпечення доступом до освіти в період кризових ситуацій (яскравим прикладом слугує пандемія COVID-19, яка демонструє відсутність злагоджених дій більшості держав щодо забезпечення усіх доступом до дистанційної освіти, яка повинна бути і якісною) тощо. 


\section{Висновки}

Отже, можна стверджувати, що право на освіту $\epsilon$ фундаментальним та невіддільним правом кожної людини. Хочемо наголосити на тому, що воно своїм сутнісним призначенням покликане сприяти людському, соціальному та економічному розвитку. Узагальнюючи міжнародний та національний досвід регламентації права на освіту, можна визначити, що освіта й, відповідно, право на освіту - це не лише складник забезпечення внутрішнього особистісного розвитку особи, але й ключовий елемент для досягнення стійкого миру та сталого розвитку. Проведений аналіз міжнародних договорів та національних нормативноправових актів засвідчив, що це право має комплексний характер, що унеможливлює віднесення його до конкретної групи прав людини, та воно охоплює такі аспекти, як рівність, доступність, безоплатність та якість освіти. Незаперечним $\epsilon$ той факт, що рівний доступ до освіти визначається на основі принципу паритетності (рівності, недискримінації).

У рамках проведеного наукового дослідження доцільно констатувати, що, незважаючи на значний доробок міжнародних та національних стандартів права на освіту, що включають цілу низку правових актів, які деталізують специфіку освітнього процесу і визначають механізм реалізації права на освіту, та існування відповідних механізмів захисту права на освіту - це право не реалізується повною мірою майже в жодній державі світу. Що пов'язане насамперед із мінливістю, невизначеністю, складністю та неоднозначністю, з якими стикається світ та кожна держава окремо.

\section{Список використаних джерел:}

1. Боняк В.О. Конституційне право людини i громадянина на освіту та його забезпечення в Україні : дис. ... канд. юрид. наук : 12.00.02. Київ, 2005. 205 с. 
Права людини в Україні та у зарубіжних країнах:

проблеми теорії та нормативно-правової регламентації

2. Всемирный доклад по мониторингу ОДВ «Образование для всех 2000-2015 гг.: достижения и вызовы». 2015. 498 с. URL: http://unesdoc.unesco.org/ images/0023/002322/232205R.pdf (дата звернення: 20.04.2020).

3. Декларация тысячелетия Организации Объединенных Наций утверждена резолюцией 55/2 Генеральной Ассамблеи от 08.09.2000 г. URL: http://zakon3.rada.gov.ua/ laws/show/995_621 (дата звернення: 20.04.2020).

4. Довідник із застосування статті 2 Протоколу № 1 до Європейської конвенції з прав людини «Право на освіту» від 30 квітня 2017 року. URL: https://www.echr.coe.int/ Documents/Guide_Art_2_Protocol_1_UKR.pdf (дата звернення: 20.04.2020).

5. Європейська соціальна хартія (переглянута) від 3 травня 1996 року. URL: https://zakon.rada.gov.ua/laws/ show/994_062 (дата звернення: 20.04.2020).

6. Загальна декларація прав людини прийнята i проголошена резолюцією 217 A (III) Генеральної Асамблеї ООН від 10 грудня 1948 року. URL: https://zakon.rada.gov.ua/ laws/show/995_015 (дата звернення: 20.04.2020).

7. Инчхонская декларация и Рамочная программа действий по осуществлению цели 4 в области устойчивого развития. URL: http://unesdoc.unesco.org/images/0024/ 002456/245656R.pdf (дата звернення: 20.04.2020).

8. Конвенція про боротьбу з дискримінацією в галузі освіти від 14 грудня 1960 року. URL: https://zakon.rada.gov.ua/laws/show/995_174 (дата звернення: 20.04.2020).

9. Конвенція Організації Об'єднаних Націй про ліквідацію всіх форм дискримінації щодо жінок від 18 грудня 1979 року. URL: https://zakon.rada.gov.ua/ laws/show/995_207 (дата звернення: 20.04.2020).

10. Конвенція про права дитини від 20 листопада 1989 року. URL: https://zakon.rada.gov.ua/laws/show/ 995_021 (дата звернення: 20.04.2020). 
11. Конвенція про права осіб 3 інвалідністю від 13 грудня 2006 року. URL: https://zakon.rada.gov.ua/laws/ show/995_g71 (дата звернення: 20.04.2020).

12. Конвенція про статус біженців від 28 липня 1951 року. URL: https://zakon.rada.gov.ua/laws/show/995_011 (дата звернення: 20.04.2020).

13. Конвенция о коренных народах, ведущих племенной образ жизни в независимых странах № 169 принята 27 июня 1989 года Генеральной конференцией Международной организации труда. URL: https://zakon.rada.gov.ua/laws/show/993_188 (дата звернення: 20.04.2020).

14. Конституція України від 28 червня 1996 року. Відомості Верховної Ради України. 1996. № 30. ст. 141.

15. Мартыненко Е.В. Международное образовательное право : учеб. пособие. Москва : РУДН, 2008. 163 с.

16. Международная конвенция о защите прав всех трудящихся-мигрантов и членов их семей от 18 декабря 1990 года. URL: https://zakon.rada.gov.ua/laws/show/ 995_203 (дата звернення: 20.04.2020).

17. Мельничук О.Ф. Право на освіту в системі конституційних прав людини і громадянина. Правничий вісник Університету «КРОК». 2011. Вип. 8. С. 16-22.

18. Міжнародний пакт про економічні, соціальні i культурні права від 16 грудня 1966 року. URL: https://zakon.rada.gov.ua/laws/show/995_042 (дата звернення: 20.04.2020).

19. Преобразование нашего мира: Повестка дня в области устойчивого развития на период до 2030 года: Резолюция, принятая Генеральной Ассамблеей ООН от 25 сентября 2015 года № A/RES/70/1. URL: https://documents-ddsny.un.org/doc/UNDOC/GEN/N15/291/92/PDF/N1529192.pdf? OpenElement (дата звернення: 20.04.2020).

20. Право на образование. Международное право. URL: http://interlaws.ru/pravo-na-obrazovanie/ (дата звернення: 20.04.2020).

21. Про вищу освіту: Закон України від 1 липня 2014 року. Відомості Верховної Ради. 2014. № 37-38. Ст. 2004. 
22. Про освіту: Закон України від 5 вересня 2017 року. Відомості Верховної Ради. 2017. № 38-39. Ст. 380.

23. Про повну загальну середню освіту: Закон України від 16 січня 2020 року. URL: https://zakon.rada.gov.ua/ laws/show/463-20 (дата звернення: 20.04.2020).

24. Рамкова конвенція про захист національних меншин від 1 лютого 1995 року. URL: (дата звернення: 20.04.2020).

25. Романенко К.М. Конституційне право громадянина на освіту в Україні: стан і тенденції розвитку : дис. ... канд. юрид. наук : 12.00.02. Запоріжжя, 2008. 213 с.

26. Спільна декларація міністрів освіти Європи «Європейський простір у сфері вищої освіти» від 19 червня 1999 року. URL: http://zakon3.rada.gov.ua/laws/show/ 994_525_(дата звернення: 20.04.2020).

27. Стульникова О.В. Конституционное право граждан на образование и проблемы его реализации в субъектах Российской Федерации : дисс. ...канд. юрид. наук : 12.00.02. Пенза, 2008. 225 с.

28. Хартия основных прав Европейского Союза. Ницца, 7 декабря 2000 года. URL: http://zakon4.rada.gov.ua/laws/ show/994_524 (дата звернення: 20.04.2020).

29. General recommendation No. 36 on girls' and women's right to education of Committee on the Elimination of Discrimination against Women, 16 November 2017. URL: https://www.right-to-education.org/sites/right-to-education.org/ files/resource-attachments/CEDAW_General_recommendation_ 36_2017_en.pdf (дата звернення: 20.04.2020).

30. Education. Legal Instruments. UNESCO. URL: http://portal.unesco.org/en/ev.php-URL_ID=13648\&URL_DO=DO_ TOPIC\&URL_SECTION=-471.html (дата звернення: 20.04.2020).

31. International Instruments "Education in Emergencies". URL: $\quad$ https://www.right-to-education.org/sites/right-toeducation.org/files/resourceattachments/RTE_International_Instruments_Education_in_Em ergencies_2014_0.pdf (дата звернення: 20.04.2020). 
32. Recommendation against Discrimination in Education UNESCO, 14 december 1960. URL: http://portal.unesco.org/ en/ev.php-URL_ID=13065\&URL_DO=DO_TOPIC\&URL_SECTION= 201.html (дата звернення: 20.04.2020).

33. Recommendation concerning Education for International Understanding, Cooperation and Peace and Education relating to Human Rights and Fundamental Freedoms. UNESCO, 19 November 1974. URL: http://portal.unesco.org/en/ev.php-

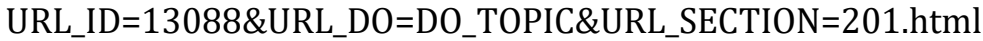
(дата звернення: 20.04.2020).

34. Reports - All EFA reports. URL: https://en.unesco.org/ gem-report/allreports (дата звернення: 20.04.2020).

35. Safe Schools Declaration. URL: http:// www.protectingeducation.org/ sites/default/files/documents/safe_schools_declarationfinal.pdf (дата звернення: 20.04.2020).

36. The Six EFA Goals // Official website of UNESCO. URL: http://portal.unesco.org/en/

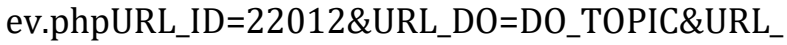
SECTION=201.html (дата звернення: 20.04.2020).

37. UNICEF's engagement in the Global Partnership for Education // Official website of UNICEF. URL: https://www.unicef.org/partners/Partnership_profile_2012_ Global_Partnership_for_Education.pdf (дата звернення: 20.04.2020). 
DOI https://doi.org/10.36059/978-966-397-210-7/91-112

Головащук А. П., кандидат юридичних наук, м. Київ

\section{РЕПРОДУКТИВНІ ПРАВА ЛЮДИНИ ЯК РІЗНОВИД ПРАВ НОВІТНІХ ПОКОЛІНЬ: ТЕОРІЯ ТА НОРМАТИВНО-ПРАВОВА РЕГЛАМЕНТАЦІЯ}

Анотація. У підрозділі розглянуто історико-правові аспекти формування різних поколінь прав людини. Окрема увага присвячена правам людини новітніх поколінь у аспекті теорії та нормативно-правової регламентації. Зокрема, досліджено репродуктивні права та їх місце у системі прав людини. Виокремлено декілька підходів до визначення місия репродуктивних прав: перший полягає у розумінні репродуктивних прав як частини права на життя; другий грунтується на тому, що репродуктивні права є складником права на здоров'я; третій підхід визначає репродуктивні права як окремий вид немайнових прав особи. Досліджено законодавче закріплення репродуктивних прав у міжнародному праві.

\section{Вступ}

Постійно перебуваючи у розвитку, людство змінюється і з'являються нові форми взаємодії та не досліджені раніше відносини і права людини, які з ними пов'язані.

Питанню дослідження прав людини як соціо-біологічної особи завжди приділялась значна увага у юридичній науці. Права людини - це можливості особи, здатні забезпечити іï розвиток у конкретно-історичних умовах, що закріплені як міжнародні стандарти, загальні і рівні для всіх людей i гарантовані законами держави як невідчужувані [19, с. 209].

Унаслідок особливостей історичного розвитку інституту «права людини» різні категорії прав виникали не одночасно, а з'являлися послідовно. Тому в науковій літературі вони були систематизовані в теорію «трьох 
поколінь прав людини». Спочатку сформувалося перше покоління - покоління природних прав людини; потім друге покоління - покоління гарантій у певних сферах життєдіяльності людини. Під час розвитку та збагачення першого та другого покоління виникло третє покоління колективних прав (національних меншин, іноземних громадян, жінок, дітей, інвалідів) [24, с. 58].

Права людини - це поняття, до складу якого входять: природні права людини; громадянські і політичні права; соціально-економічні і культурні права. Однак новітні розробки і відкриття у галузях медицини та сучасних технологій звертає увагу юристів на питання захисту та реалізації прав людини, які пов'язані з новітніми науковими відкриттями, а також сприяють появі нових прав людини, які раніше не були дослідженими. Одними з таких прав $\epsilon$ репродуктивні права людини. Репродуктивні права пов'язані зі здоров'ям людини та з продовженням роду, тому їх слід розглядати як складник природних прав людини.

Нині необхідні грунтовні дослідження історикоправових та теоретико-правових позицій, які зумовлюють процес появи та формування прав новітніх поколінь, а також причини, які зумовлюють їх виникнення.

\section{1. Історико-правові аспекти формування різних поколінь прав людини}

Науковці здавна приділяють увагу дослідженню ідеї про права людини. Твердження, які закріплюють рівність людей, цінність та недоторканність людського життя, завжди були у центрі наукових досліджень.

Активно ідею прав людини досліджували у період XVII - XVIII століть, що знайшло своє відображення у теорії природного права. У роботах таких мислителів, як Дж. Локк, Ж.-Ж. Руссо, Ш. Монтеск'є, I. Кант та багатьох інших відображалося утвердження прав людини на життя та свободу.

Фундаментальним нормативно-правовим актом міжнародного рівня, у якому відбулось закріплення ідеї 
прав людини, $\epsilon$ Загальна декларація прав людини, прийнята і проголошена у резолюції 217 А (III) Генеральної Асамблеї ООН від 10 грудня 1948 року. Цей документ започаткував глобальний процес зміни характеру права i означився утвердженням свободи і справедливості у різних країнах світу.

Досліджуючи ідею прав людини, закономірно виникла необхідність систематизувати здобуті знання, тому виникла теорія трьох поколінь прав людини.

До першого покоління прав відносять особисті та невідчужувані права, зокрема, право на життя, свободу і особисту безпеку та інші. До числа перших нормативноправових актів, де відбулося закріплення цих прав людини, можна віднести:

1) англійські акти Петиція про права (1628 р.), Habeas Corpus Act (1679 р.) та Білль про права (1689 р.);

2) Декларація незалежності США (1776 р.);

3) Білль про права (США, 1791 р.);

4) французька Декларація прав людини і громадянина (1789 р.) та інші.

Якщо права першого покоління це передусім природні права, то права другого покоління $\epsilon$ поглибленням особистих і розвитком соціально-економічних прав. Вони можуть розглядатися як розширення та розвиток вихідної ідеї природних прав людини. Друге покоління прав людини сформувалося під впливом змін в економічній сфері країн.

Права другого покоління були закріплені в Міжнародному пакті про економічні, соціальні і культурні права (1966 р.). Визнання другого покоління прав людини означало суттєві зміни у самій концепції. В основі цих змін лежало позитивне розуміння свободи, як реального здійснення своєї волі нарівні з іншими людьми [10, с. 566].

Визнання третього покоління прав людини зумовлено розвитком перших двох поколінь прав людини та суспільства загалом. Це покоління прав людини називається колективним чи солідарним. Тобто це не 
виокремлення нових прав людини, а реалізація особистих, політичних, соціальних, економічних та культурних прав сумісно, окремими групами. Права третього покоління покликані подолати автономію окремих індивідів, що конкурують між собою, і забезпечити соціальну солідарність, що дозволить людям повністю розкрити свій потенціал за допомогою спільної участі в соціальному житті різних співтовариств, до яких вони належать [24, с. 59].

Процеси активного розвитку науки, компютерних технологій, інформатизації, гуманізації, проведення новітніх та технологічно складних досліджень у біологї̈, медицині, космічній сфері започаткували новий етап розвитку права і зумовили появу четвертого покоління прав людини.

В 1996 р. А.П. Семітко запропонував виділити права четвертого покоління, до яких необхідно віднести права людини, пов'язані із здійсненням абортів, евтаназії. Серед науковців немає єдиного погляду стосовно визначення, які саме права слід віднести до прав четвертого покоління. У науковій літературі можемо виділити такі погляди на досліджуване питання:

1) права четвертого покоління розглядають як «право на фізичну свободу»;

2) обмежують правом на самогубство та на евтаназію, причому евтаназію та самогубство розглядають як елементи права на смерть;

3) права четвертого покоління повинні захищати людину від загроз, пов'язаних з експериментами в сфері генетичної спадковості особи, тобто це такі права людини, які пов'язані з клонуванням та іншими відкриттями в сфері біології;

4) деякі науковці зараховують лише інформаційні права та технологї̈;

5) називають четвертим поколінням права людства: право на мир, на ядерну безпеку, космос, екологічні, інформаційні права тощо; 
6) виділяють особистісні (соматичні) права як права людини розпоряджатися своїм тілом, в тому числі клонувати;

7) до прав четвертого покоління зараховують право на евтаназію, на зміну статі, на трансплантацію органів, на використання віртуальної інформації, право на клонування;

8) четверте покоління прав людини повинне формуватися на таких засадах: визнання високого статусу особи; прагнення єдності норм права, моралі, релігії під час визначення поведінки як правової; визнання права на індивідуальність особи, що передбачає повагу до особливих потреб людини, які надають їй можливість бути не схожою на інших; установлення суверенності людини щодо держави [1, с. 214-215].

Як зазначає С.В. Несинова, біологічні права (від грецького bios - життя, logos - слово, наука) - це права, які визначаються біологічною структурою організму людини, його біологічними потребами. Відповідно до наявної класифікації прав людини у науковій літературі до біологічних (соматичних) прав людини і громадянина відносять такі права:

1) право на смерть (включаючи евтаназію);

2) права людини щодо ії органів і тканин. Це так звані права людини на вільне розпорядження своїм тілом $\mathrm{i}$ тілами близьких людей, на клонування, як усього організму, так і окремих органів, і трансплантацію органів;

3) репродуктивні права людини (позитивного характеру (штучне запліднення) та негативного характеру (аборт, стерилізація, контрацепція));

4) право на зміну статі і вибір статі дитини;

5) право на вживання наркотиків i психотропних речовин та інші права, які, на думку деяких вчених, претендують на закріплення в законодавстві з подальшим розвитком генетики та медицини [12, с. 38].

Четверте покоління прав $€$ новітніми правами людини $\mathrm{i}$ пов'язані із розвитком суспільства, науки, техніки, 
технологій і відповідних відносин у різних галузях. Без розвитку суспільства досліджувані права не могли б виникнути і сформуватись.

Вивчаючи проблематику новітніх прав людини, необхідно звернути увагу, що вони виникають у тих сферах життя людини, які зазнають найбільших змін у останні два десятиліття. Зокрема, інформаційно-комунікаційні технології, медицина, біотехнології, нанотехнології, штучний інтелект та інші.

Підсумовуючи усе зазначене вище, можемо виділити такі види прав четвертого покоління: право на евтаназію; репродуктивні права; право на трансплантацію; право на донорство; право на зміну статі; право на вибір статі дитини; права у інформаційно-комунікаційній сфері; екологічні права; права, які виникають у космічній галузі, та інші.

Наведений перелік прав не може бути вичерпним, оскільки сьогодні відбувається активний розвиток науки, технологій та техніки. Що своєю чергою буде призводити до появи різноманітних відносин, які необхідно буде врегулювати правом та визначити права учасників таких нових відносин.

\section{2. Характеристика репродуктивних прав людини}

Оскільки репродуктивні права людини привернули увагу правників відносно нещодавно, виникає потреба визначити місце цих прав у системі прав людини. У науковій літературі нині немає єдиного розуміння щодо визначення місця репродуктивних прав. Оскільки репродуктивні права у спеціальній літературі розглядаються як пов'язані 3 іншими особистими немайновими правами, а саме з правом на життя, правом на охорону здоров'я, правом на недоторканність особистого i сімейного життя. Тому існування різних поглядів на репродуктивні права зумовлює наявність декількох підходів до визначення місця репродуктивних прав у 
системі особистих немайнових прав людини, а також розумінням того, чи займають досліджувані права окреме місце, $є$ вони складниками інших немайнових прав чи $\epsilon$ похідними від них.

Перш ніж перейти до розгляду підходів щодо визначення місця репродуктивних прав, відзначимо, що аналіз міжнародних нормативно-правових актів дозволяє визначити репродуктивні права як комплексні, які включають в себе два складники: 1) право на продовження роду; 2) право на репродуктивне здоров'я. Подібного погляду дотримується О. Хазова, вважаючи, що репродуктивні права $\epsilon$ комплексним інститутом, сукупністю повноважень [21, с. 297]. Розглянемо складові елементи репродуктивних прав.

Зміст права на продовження роду, на наш погляд, становить можливість фізичної особи вільно, на власний розсуд визначати свою поведінку у сфері свого приватного життя стосовно того, коли і скільки народжувати дітей, інтервали між їх народженням. Реалізувати право на продовження роду фізична особа може через народження власної дитини, як у природній спосіб, так і застосовуючи допоміжні репродуктивні технології [4, с. 35].

Право на продовження роду тісно взаємопов'язано 3 правом на репродуктивне здоров'я. Визначення поняття «репродуктивне здоров'я» міститься у Пекінській платформі дій 1995 року, де зазначено: «репродуктивне здоров'я - це стан повного фізичного, розумового i соціального благополуччя, а не просто відсутність хвороб або недуг у всіх питаннях, що стосуються репродуктивної системи та ї̈ функцій і процесів. Тому репродуктивне здоров'я передбачає, що у людей $\epsilon$ можливість мати безпечне статеве життя. Останнє передбачає право чоловіків і жінок бути поінформованими і мати доступ до безпечних, ефективних, доступних і прийнятних методів планування сім'ї за їх вибором, а також інших методів регулювання дітонародження за їх вибором, які не 
суперечать закону, і право мати доступ до відповідних послуг у галузі охорони здоров'я, які дозволили б жінкам успішно пройти через етап вагітності та пологів і надали б подружнім парам найкращий шанс мати здорове немовля». Відповідно до викладеного вище визначення репродуктивного здоров'я охорона репродуктивного здоров'я визначається як поєднання методів, способів і послуг, які сприяють репродуктивному здоров’ю та добробуту за рахунок попередження та усунення проблем, пов'язаних 3 репродуктивним здоров'ям. Охорона репродуктивного здоров'я також включає охорону сексуального здоров'я, метою якої $€$ поліпшення життя i особистих відносин, а не просто надання консультативних та медичних послуг, пов'язаних 3 репродуктивною функцією і захворюваннями, що передаються статевим шляхом (п. 94) [14].

У науковій літературі висловлена думка, з якою автор погоджується, що репродуктивне здоров'я забезпечує можливість і здатність до відтворення. Все це передбачає право чоловіків та жінок на інформацію і доступ до безпечних, ефективних і прийнятних методів планування сім'ї, а також право доступу до відповідних послуг 3 охорони здоров'я, які дозволять жінці безпечно перенести вагітність та пологи і надають батькам найкращу можливість народити здорову дитину [3, с. 20].

3 огляду на зазначене вище можемо визначити, що репродуктивне здоров'я за своїм змістом охоплює лише один складник - репродуктивну функцію людини, тоді як визначення поняття здоров'я включає в себе загалом усі складники здоров'я людини, у тому числі і репродуктивну функцію. А отже, поняття «репродуктивне здоров'я» i «здоров'я» будуть співвідноситися між собою як загальне і часткове, тобто репродуктивне здоров'я $\epsilon$ частиною загального здоров'я людини. Фізична особа може самостійно розпоряджатися своїм репродуктивним 
Права людини в Україні та у зарубіжних країнах:

проблеми теорії та нормативно-правової регламентації

здоров'ям шляхом застосування передбачених законодавством методів допоміжних репродуктивних технологій (далі - ДРТ).

Право на репродуктивне здоров'я, на нашу думку, включає в себе:

- право на застосування ДРТ - фізична особа може скористатися допоміжними репродуктивними технологіями відповідно до умов та порядку, визначених законодавством країни;

- право на інформацію про репродуктивні права фізична особа має отримати усю необхідну їй інформацію про ऑï̈ репродуктивне здоров'я; про діагностику, профілактику та лікування захворювань, пов'язаних із репродуктивною функцією; про методи ДРТ, їх переваги, недоліки та пов'язані 3 ними ризики; про виникнення можливих ускладнень під час проходження ДРТ;

- право на захист репродуктивних прав. За українським законодавством кожна особа має право на захист свого цивільного права у разі його порушення, невизнання або оспорювання (ст. 15) [23]. Захист репродуктивних прав фізичної особи здійснюватиметься у судовому порядку.

На думку О.Р. Шишки, зміст репродуктивних прав людини має як позитивний характер (право на материнство та батьківство, право на профілактику та лікування безпліддя, право на штучне запліднення, право на донорство та збереження репродуктивних клітин, право на штучне запліднення й імплантацію ембріона, право на використання методу сурогатного материнства), так i негативний характер (штучне переривання вагітності, стерилізація, контрацепція) [25].

Аналіз наукової літератури дозволяє виокремити такі підходи до визначення місця репродуктивних прав: перший полягає у розумінні репродуктивних прав як частини права на життя; другий грунтується на тому, що репродуктивні права $\epsilon$ складником права на охорону 
здоров'я; третій підхід визначає репродуктивні права як окремий вид немайнових прав особи [4, с. 37]. Розглянемо кожен з цих підходів та визначимо місце репродуктивних прав у законодавстві України.

Відповідно до першого підходу репродуктивні права розглядаються як частина права на життя. Чинне законодавство України захищає право на життя. Конституцією України визначено, що кожна людина має невіддільне право на життя. Ніхто не може бути свавільно позбавлений життя. Обов'язок держави - захищати життя людини (ст. 27) [9]. Цивільним кодексом України встановлено, що фізична особа не може бути позбавлена життя (ст. 281) [23]. Цивільний кодекс України, відносячи право на проведення ДРТ до ст. 281, якою закріплюється право на життя, тим самим визначає це право саме складником права на життя. Однак досліджувані права будуть різнитися за своїм об'єктом. Так, об'єктом права на життя є саме життя як особисте немайнове благо, тоді як об'єктом репродуктивних прав є репродуктивне здоров'я людини. На думку Г.Б. Романовського, безпосереднім призначенням репродуктивних прав $\epsilon$ забезпечення продовження життя [18, с. 67]. Досліджуючи проблематику репродуктивних прав, науковець М.М. Малеїна доводить хибність першого підходу, зазначаючи, що ставлення до штучного запліднення та імплантації ембріона має відношення до інтересів саме батьків. Зміст права на життя можуть складати тільки ті повноваження, які належать вже існуючому суб'єкту, людині, яка народилась. Повноваження на проведення штучного запліднення, імплантації ембріона не належать, а закріплені за майбутніми батьками, але не як складники права на життя, а як складники права на охорону здоров'я [17, с. 59]. Отже, тим самим М.М. Малеїна доводить, що репродуктивні права не $\epsilon$ складником права на життя, а мають розглядатися як складник права на охорону здоров'я.

Зауважимо, що українське законодавство відносить право на застосування ДРТ до права на життя, але така 
позиція видається не зовсім коректною. Оскільки репродуктивні права більше пов'язані з правом на охорону здоров'я, ніж з правом на життя, що доводить правильність другого підходу до визначення місця репродуктивних прав.

Відповідно до другого підходу репродуктивні права розглядають як складник права на охорону здоров'я. Учинному законодавстві України використовуються терміни «право на охорону здоров'я» та «здоров'я». Закон України «Основи законодавства України про охорону здоров’я» № 2801-XII від 19 листопада 1992 року дає такі визначення: здоров'я - це стан повного фізичного, душевного i соціального благополуччя, а не тільки відсутність хвороб і фізичних дефектів; охорона здоров'я це система заходів, спрямованих на забезпечення збереження i розвитку фізіологічних i психологічних функцій, оптимальної працездатності та соціальної активності людини за максимальної біологічно можливої індивідуальної тривалості життя (ст. 3) [13]. Конституцією України визначено, що кожен має право на охорону здоров'я, медичну допомогу (ст. 49) [9]. Цивільний кодекс України відносить право на охорону здоров'я до особистих немайнових прав, що забезпечують природне існування фізичної особи. Охорона здоров'я забезпечується системною діяльністю державних та інших організацій, передбаченою Конституцією України та законом (ст. 283) [23]. Об'єктом права на охорону здоров'я $\epsilon$ саме здоров'я як особисте немайнове благо людини.

Досліджуючи поняття та зміст права на охорону здоров'я, 0.0. Пунда пише, що в основі цього права лежить благо на відносне індивідуальне здоров'я. Виникає досліджуване право одночасно з правом на життя. Вчений виділяє такі структурні елементи цього права: право на охорону здоров'я; право на медичну допомогу; право на медичну інформацію; право на медичне страхування. На його думку, право на охорону здоров'я як особисте немайнове право полягає у сукупності можливостей фізичної особи вільно, на власний розсуд визначити свою 
поведінку щодо індивідуального здоров'я. Здійснення права на охорону здоров'я пов'язане 3 регулюванням відносин щодо провадження споживання блага здоров'я самостійно або за допомогою інших осіб [16, с. 84].

На думку Е.Е. Мухамедової, репродуктивним правам більшою мірою притаманна природа особистого немайнового права фізичної особи на охорону здоров'я, невіддільним елементом якого вони виступають. Здійснення особою репродуктивних можливостей відбувається в межах реалізації цього особистого немайнового права кожної фізичної особи, а його приватноправове регулювання дає можливість кожній особі самостійно обирати ті чи інші способи реалізації власних можливостей, у тому числі й репродуктивних [11, с. 138].

Подібного погляду дотримується Н. Тюхтій, вважаючи, що репродуктивні права $є$ складником права на охорону здоров'я [22, с. 73].

Зауважимо, що реалізація особою своїх репродуктивних прав дійсно пов'язана 3 реалізацією права на охорону здоров'я. Також відзначимо про наявність зв'язку між правом на репродуктивне здоров'я і правом на охорону здоров'я. На перший погляд репродуктивні права і справді можуть здаватись невіддільним елементом права на охорону здоров'я, як відзначає E.E. Мухамедова, однак різниця у їх об'єктах не дозволяє це стверджувати.

Третього погляду дотримується український вчений P.O. Стефанчук, вважаючи, що розуміння репродуктивних прав винятково як складника права на охорону здоров'я $\epsilon$ доволі вузьким. Водночас тлумачення репродуктивних прав винятково як складника права на життя, також $\epsilon$ недопустимим, оскільки право на життя має свою чітко визначену структуру щодо володіння та користування життям для задоволення власних потреб та інтересів. Тому, на його думку, репродуктивні права повинні розглядатись як система відокремлених особистих немайнових прав фізичних осіб, що забезпечують їх 
природне існування та спрямовані на здійснення репродуктивної функції фізичних осіб [20, с. 348-349].

Дослідивши три підходи до визначення місця репродуктивних прав, а також погляди різних науковців, та проаналізувавши законодавство України, можемо сформулювати власну позицію.

По-перше, ми погоджуємось 3 доводами М.М. Малеїної щодо неможливості розгляду репродуктивних прав як частини права на життя. Також підтримуємо думку P.0. Стефанчука щодо недопустимості тлумачення репродуктивних прав як складника права на життя. Вважаємо, що тільки вже народжена людина має право на життя. Також ми вважаємо позицію Р.О. Стефанчука стосовно виокремлення репродуктивних прав слушною, оскільки це дозволяє визначити їх місце серед інших особистих немайнових прав людини, а також з'ясувати їх об’єкт. Разом з цим автор не поділяє думку Р.О. Стефанчука, що розуміння репродуктивних прав винятково як складника права на охорону здоров'я $€$ доволі вузьким. Оскільки, на наш погляд, репродуктивні права стосуються репродуктивного здоров'я людини, яке своєю чергою $\epsilon$ складником здоров'я людини i, як ми зазначали вище, ці два поняття співвідносяться як часткове та загальне. Репродуктивне здоров'я не можна розглядати окремо або відірвано від здоров'я людини загалом. Дійсно, не можна відкидати і прямий зв'язок репродуктивних прав з правом на охорону здоров'я, однак стверджувати, що досліджувані права $\epsilon$ саме невіддільним елементом права на охорону здоров'я, ми не можемо, бо зазначені права відрізняються за своїм об'єктом. Репродуктивні права, як й інші особисті немайнові права, відповідно до положень Цивільного кодексу України належать кожній фізичній особі від народження, не мають економічного змісту i тісно пов'язані з фізичною особою (ст. 269) [23]. Репродуктивні права не можуть бути передані іншій фізичній особі 3 огляду на те, що вони $є$ природною властивістю людини. 
Можемо визначити, що репродуктивні права мають бути виділені в окрему підгрупу прав, які пов'язані 3 правом на охорону здоров'я.

Визначивши місце репродуктивних прав у системі особистих немайнових прав людини, перейдемо до розгляду законодавчого закріплення досліджуваних прав.

Міжнародним нормативно-правовим документом, у якому було закріплено право кожної людини на користування результатами наукового прогресу та їх практичного застосування, $\epsilon$ Віденська Декларація та Програма дій, які прийняті Всесвітньою конференцією 3 прав людини 25 червня 1993 року у Відні. Всесвітня конференція з прав людини у зазначеному документі наголошує, що прогрес у біомедичних і біологічних науках може мати потенційно негативні наслідки для недоторканності, гідності та прав людської особистості, i закликає здійснювати міжнародне співробітництво 3 метою забезпечення повної поваги прав і гідності людини в цій сфері, що знаходиться в центрі уваги всього людства [2]. Із наведеного положення зрозуміло, що на міжнародному рівні закріплено право кожної людини користуватися результатами наукового прогресу, зокрема і допоміжними репродуктивними технологіями, але таке їх застосування має здійснюватися за умови поваги до прав і гідності людини.

Вперше закріплення поняття репродуктивних прав відбулося у Каїрі у 1994 році на Міжнародній конференції з народонаселення та розвитку, де була прийнята Програма дій, у якій глава 7 присвячена репродуктивним правам і репродуктивному здоров'ю. У Програмі дій визначено, що репродуктивні права охоплюють деякі права людини, які вже визнані у національних законодавствах, міжнародних документах 3 прав людини та інших відповідних документах ООН, прийнятих на основі консенсусу. Вказані права ґрунтуються на визнанні основного права всіх подружніх пар і окремих осіб вільно приймати рішення стосовно кількості своїх дітей, інтервалів між їх 
народженням, часу їх народження i мати для цього необхідну інформацію, засоби і право на досягнення максимально високого рівня репродуктивного здоров'я. Відповідно до положень Програми дій охорона репродуктивного здоров'я визначається як поєднання методів, способів і послуг, які сприяють репродуктивному здоров'ю і благополуччю за рахунок попередження i усунення проблем, пов'язаних з репродуктивним здоров'ям (п. 7.2 та 7.3) [7].

Як стає зрозуміло із положення Програми дій, репродуктивні права людини міжнародним правом визначаються у комплексі, тобто як такі, що пов'язані 3 іншими правами людини, які раніше вже були визнані та захищені різноманітними міжнародними документами [5, с.79]. Аналізуючи норми Програми дій, можемо визначити, що основу репродуктивних прав складають права людини, пов'язані із здоров'ям, продовженням свого роду та доступом до необхідної інформації у сфері репродуктивного здоров'я.

Надалі увага питанню репродуктивних прав була приділена на Четвертій Всесвітній конференції зі становища жінок, яка відбулась у Пекіні у 1995 році, де було затверджено Платформу дій, у якій передбачено, що репродуктивні права включають право подружніх пар i окремих осіб приймати рішення стосовно відтворення потомства без будь-якої дискримінації, примушування чи насилля, про що йдеться у документах з прав людини. Під час здійснення цього права подружні пари і окремі особи повинні враховувати потреби своїх існуючих i майбутніх дітей і свою відповідальність перед суспільством (п. 95) [14]. Зазначений документ передбачає свободу особи у питанні народження дітей і продовження свого роду та не допускає порушення прав людини у сфері відтворення потомства.

До числа міжнародних нормативно-правових актів, які захищають репродуктивні права жінок, належить Конвенція ООН про ліквідацію всіх форм дискримінації 
щодо жінок від 18 грудня 1979 року, яка підписана Україною 17 липня 1980 року і ратифікована 12 березня 1981 року. У преамбулі цієї Конвенції закріплено принцип заборони дискримінації жінки стосовно іï ролі у продовженні роду, зазначено про значення внеску жінок у добробут сім'ї та у розвиток суспільства, що до цього часу не одержав повного визнання, соціальне значення материнства та ролі обох батьків у сім'ї та у вихованні дітей і про те, що роль жінки у продовженні роду не повинна бути причиною дискримінації [15].

Конвенцію також слід розглядати і в аспекті захисту жінок від дискримінації у питанні прав, що стосуються репродуктивної сфери. Зокрема, згідно із нормами, закріпленими у цьому міжнародному документі, держависторони вживають усіх відповідних заходів для того, щоб ліквідувати дискримінацію щодо жінок, 3 тим щоб забезпечити їм доступ до спеціальної інформації освітнього характеру для сприяння забезпеченню здоров'я і добробуту сімей, включаючи інформацію та консультації про планування розміру сім'ї (ст. 10) [15]. Норми цієї Конвенції надають жінкам рівні права 3 чоловіками на отримання інформації у сфері здоров'я та планування сім'ї, а отже, на отримання повної i достовірної інформації 3 питань, які стосуються репродуктивного здоров'я, у тому числі і про ефективність, переваги та можливі ризики допоміжних репродуктивних технологій.

Також положення розглядуваної Конвенції спрямоване на захист трудових прав жінок з тим, щоб забезпечити на основі рівності чоловіків і жінок рівні права, зокрема: право на охорону здоров'я та безпечні умови праці, включаючи захист репродуктивної функції; забезпечувати жінкам особливий захист у період вагітності на тих видах робіт, шкідливість яких для здоров'я доведена. Аналізуючи зміст Конвенції, звертаємо увагу на ст. 12, якою передбачається вживання державами-сторонами усіх 
відповідних заходів для ліквідації дискримінації щодо жінок у галузі охорони здоров'я, з тим, щоб забезпечити на основі рівності чоловіків і жінок доступ до медичного обслуговування, зокрема в тому, що стосується планування розміру сім'ї. Жінкам має забезпечуватись відповідне обслуговування в період вагітності, пологів i післяпологовий період, надаючи, коли це необхідно, безплатні послуги [15]. 3 огляду на зазначене вище можемо констатувати, що Конвенція про ліквідацію всіх форм дискримінації щодо жінок забезпечує жінкам рівність у праві на отримання послуг з охорони репродуктивного здоров'я і планування сім'ї. Забезпечує жінкам право визначати кількість дітей, проміжок часу, через який їх народжувати, мати можливість скористатися допоміжними репродуктивними технологіями, а також бути захищеною від примусової вагітності, аборту чи будь-якого іншого порушення іï репродуктивних прав. Також жінки мають право на безпечне материнство, тобто на таку медикосоціальну допомогу, яка зводиться до мінімального ризику для іï здоров'я та здоров'я дитини в період вагітності, пологів і післяпологовий період [6].

Увагу репродуктивним правам також приділено у Заклику Тегеранської конференції від 13 травня 1968 року. Згідно з положеннями цього документу батьки мають невіддільне право вільно і з почуттям відповідальності визначати число дітей і терміни їх народження [8].

3 позиції міжнародного права репродуктивні права були закріплені у низці міжнародних нормативно-правових актів. Однак на міжнародному рівні репродуктивні права не виокремлюються серед інших прав людини у системі особистих немайнових прав і розглядаються як частина права на охорону здоров'я та права на медичну допомогу.

\section{Висновки}

Репродуктивні права стосуються життєвих інтересів кожної людини. Їх реалізація залежить від усвідомлення 
людьми своїх прав і готовності відстоювати і захищати їх від будь-яких порушень.

Відзначимо, що визначення поняття «репродуктивні права» у наведених вище міжнародних документах $\epsilon$ нечітким або відсутнім. Дослідивши законодавство України щодо репродуктивних прав, відзначимо, що у ньому відсутнє визначення поняття «репродуктивні права».

На нашу думку, репродуктивні права - це похідні від права на охорону здоров'я особисті немайнові права фізичної особи, які пов'язані з репродуктивним здоров'ям людини і полягають у здатності людини вільно приймати рішення стосовно народження дитини, кількості та інтервалів між народженням дітей, застосування ДРТ. Об'єктом репродуктивних прав $\epsilon$ репродуктивне здоров'я людини [4, с. 94].

Репродуктивні права поділяються на два складники: перший - це право на продовження роду, а другий - це право на репродуктивне здоров'я.

Зміст права на продовження роду становить можливість фізичної особи вільно, на власний розсуд визначати свою поведінку у сфері свого приватного життя стосовно того, коли і скільки народжувати дітей, інтервали між їх народженням, а також вирішувати, народжувати дітей у офіційно зареєстрованому шлюбі чи ні. Реалізувати право на продовження роду фізична особа може через народження власної дитини, як у природній спосіб, так і застосовуючи допоміжні репродуктивні технології.

Право на репродуктивне здоров'я включає в себе: право на інформацію про репродуктивні права; право на захист репродуктивних прав; право на застосування ДРТ.

Право на застосування ДРТ означає, що фізична особа може скористатися допоміжними репродуктивними технологіями відповідно до умов та порядку, визначених національним законодавством.

Право на інформацію про репродуктивні права означає, що фізична особа має право отримати усю необхідну їй інформацію про її репродуктивне здоров'я; про діагностику, 
профілактику та лікування захворювань, пов'язаних 3 репродуктивною функцією; про методи ДРТ та їх переваги, недоліки та пов'язані з ними ризики; про виникнення можливих ускладнень під час проходження ДРТ.

Виділимо деякі ознаки, які характеризують репродуктивні права:

1) ці права є загальними для всіх людей і діють поза державою, мають юридичний характер і не можуть бути відібрані за волею держави, тому вони є природними;

2) вони належать людині від народження та мають природний характер, тому є невідчужуваними;

3) людина наділена досліджуваними правами за своєю природою, а отже, вони є невід'ємними;

4) репродуктивні права належать кожній людині, вони $\epsilon$ наднаціональними та екстериторіальними діють у будьякий час, а тому є універсальними;

5) ці права визначаються потребами людини, їх існування є об'єктивним, як наслідок факту народження, i спрямовані на задоволення потреб, без яких людина не в змозі існувати;

6) оскільки досліджувані права не припиняються і не виникають, щоразу вони мають постійний характер.

\section{Список використаних джерел:}

1. Барабаш 0.0. Четверте покоління прав людини: загальнотеоретична характеристика. Вісник Національного університету «Львівська політехніка». Юридичні науки. 2016. № 837. С. 213-217.

2. Віденська Декларація та Програма дій прийнята Всесвітньою конференцією по правам людини від 25.06.1993 р. (Відень). URL: http://zakon4.rada.gov.ua/laws/ show/995_504.

3. Гойда Н.Г., Бісярін О.Ю. Нормативно-правове регулювання діяльності служби планування сім'ї та 
збереження репродуктивного здоров'я. Актуальні питання клінічної практики. 2012. № 4. С. 20-25.

4. Головащук А.П. Цивільно-правове регулювання відносин, пов'язаних із застосуванням допоміжних репродуктивних технологій : дис. ... к.ю.н. 12.00.03 / Інститут держави і права ім. В.М. Корецького НАН України. 2017. 258 c.

5. Головащук А.П. Актуальні питання захисту репродуктивних прав людини в умовах сьогодення. Huтап Rights: Theory and Practic: collection of scientific papers of First International educational and scientific forum, (Poland, January 23-28, 2017). London : IASHE, 2017. P. 78-81.

6. Гончаренко О.М. Права жінки та права дитини: співвідносний аналіз. Науковий вісник національного університету біоресурсів і природокористування Украӥни. Серія: «Право». Київ, 2011. Вип. 165, ч. 1. С. 36-40. URL: http://www.nbuv.gov.ua/portal/soc_gum/nvnau_pravo/ 2011_165_1/11gom.pdf.

7. Доповідь Міжнародної конференції по народонаселенню і розвитку. Програми дій Міжнародної конференції по народонаселенню та розвитку (Каїр, 05-13 вересня 1994 p.). URL: http://www.unfpa.org/sites/ default/files/pub-pdf/icpd_rus.pdf.

8. Заклик Тегеранської конференції (Тегеран, 13 трав. 1968 p.). URL: http://zakon4.rada.gov.ua/laws/show/995_900

9. Конституція України: Закон України від 28.06.1996 p. № 254к/96-ВР. Відомості Верховної Ради України. 1996. № 30. Ст. 141.

10. Лазур Я.В. Щодо класифікації прав і свобод людини. Форум права. 2011. № 1. С. 565-569.

11. Мухамєдова Е.Е. Репродуктивні права фізичної особи в системі особистих немайнових прав. Ученые записки Таврического национального университета им. В. И. Вернадского. Серия: «Юридические науки». 2012. № 2, т. 25 (64). С. 136-141. 
12. Несинова С.В., Князєва Ю.С. Нове покоління прав людини: сучасні проблеми класифікації. Вісник Дніпропетровського університету імені Альфреда Нобеля. Серія : Юридичні науки. 2015. № 2. С. 36-42.

13. Основи законодавства України про охорону здоров’я: Закон України від 19.11.1992 р. № 2801-XII (із змінами та доповненнями). Відомості Верховної Ради України. 1993. № 4. Ст. 19.

14. Платформи дій $=$ Platform of Action: затверджена у Доповіді Четвертої Всесвітньої конференції по становищу жінок (Пекін, 04-15 вересня 1995 р.). URL: http://www.un.org/ womenwatch/daw/beijing/pdf/Beijing\%20full\%20report $\% 20$ R.pdf.

15. Про ліквідацію всіх форм дискримінації щодо жінок: Конвенція ООН від 18.12.1979 p. URL: http://zakon4.rada.gov.ua/laws/show/ 995_207/page.

16. Пунда 0.0. Поняття та зміст права на здоров'я. Вісник Хмельницького інституту регіонального управління та права. 2003. № 3-4 (7-8). С. 58-64.

17. Пунда 0.0. Право на життя. Вісник Хмельницького інституту регіонального управління та права. 2003. № 2 (6). С. 58-64.

18. Радиш Я.Ф., Поживілова Р.В., Гакало В.В. Репродуктивні права в Україні та країнах СНД: за матеріалами літературних джерел (до проблеми державного регулювання розвитку репродуктивного здоров'я в Україні). Інвестиції: практика та досвід. 2011. № 10. С. 66-68.

19. Скакун О.Ф. Теорія держави і права (Енциклопедичний курс): підручник. 2-е вид., перероб. і доп. Харків : Еспада, 2009. 752 с.

20. Стефанчук Р.О. Особисті немайнові права фізичних осіб (поняття, зміст, система, особливості здійснення та захисту) : монографія / відп. ред. Я. М. Шевченко. Київ : КНT, 2008. 626 c. 
21. Стефанчук Р.О. Репродуктивні права фізичної особи: поняття, система, особливості здійснення. Вісник Львівського університету. Серія: «Право». 2004. Вип. 39. C. 296-304.

22. Тюхтій Н. Репродуктивні особисті немайнові права фізичних осіб. Юридична Україна. 2013. № 6. С. 70-75.

23. Цивільний кодекс України: Закон України від 16.01.2003 p. № 435-IV (із змінами та доповненнями). Відомості Верховної Ради України. 2003. № 40-44. Ст. 356.

24. Шебаніц Д.М. Сучасна проблематика теорії «поколінь прав людини» в умовах європейської міждержавної інтеграції. Науковий вісник Ужгородського національного університету. Серія Право. 2015. Вип. 31. Т. 1. C. 57-61.

25. Шишка О.Р. Право не існуючого учасника правових відносин як правова фікція. URL: http://www.nbuv.gov.ua/ e-journals/prtup/2011_1/pdf/ 11sopjpf.pdf. 
Права людини в Україні та у зарубіжних країнах:

проблеми теорії та нормативно-правової регламентації

DOI https://doi.org/10.36059/978-966-397-210-7/113-135

Гулиев Ариф Джамиль оглы,

доктор юридических наук, профессор, заслуженный работник образования Украины, профессор кафедры международного права Национального авиационного университета, 2. Киев

\section{НАРОДНАЯ ДИПЛОМАТИЯ КАК ДЕЙСТВЕННЫЙ ИНСТРУМЕНТ ДЕМОКРАТИЧЕСКОГО РАЗВИТИЯ ОБЩЕСТВА ${ }^{2}$}

Аннотация. Рассматривается принципиальная позиция, народная дипломатия, чтобы представители разных стран, со своими особенностями, со специфическими проблемами и целями, с разным экономическим и военным потенциалом, прониклись уважением и дружелюбием друг к другу. Только на основе этих чувств людей ждет безопасная жизнь, полная приятных и интересных дел.

Таким образом, общественная дипломатия - это своего рода форма ответа на глобальные вызовы и угрозы, на становление нового мирового порядка, на ход внутриполитического развития. Неслучайно она стала более актуальной в эпоху глобализации, глубоких общественных изменений и стремительного развития цивилизаций. Дружба - как спокойная и тихая привязанность, направляемая и укрепляемая привычкой, возникающей из долгого общения и взаимных обязательств, укрепляет лишь достойных людей.

\section{Введение}

Народная дипломатия гражданского общества является частью механизма демократизации внешней и внутренней политики государства.

2 Гулиев А.Д. Народная дипломатия как действенный инструмент демократического развития общества. Держава і право : зб. наук. праць. Київ : Ін-т держави і права ім. В.М. Корецького НАН України. 2013. № 61. C. 3-10. 
Права людини в Україні та у зарубіжних країнах:

проблеми теорії та нормативно-правової регламентації

Народная дипломатия (или неофициальная, гражданская дипломатия) как явление существует уже многие столетия, начиная с древних времен и вплоть до наших дней. Однако сам термин «народная дипломатия»относительно новый. Он обозначает неофициальные контакты между обычными людьми, которые способствуют улучшению отношений между государствами и народами. Первоначально термин «народная дипломатия» относился к частным инициативам обычных граждан, осуществлявших переговоры с целью прекращения продолжающегося конфликта и решения других международных проблем. Ценность таких неофициальных контактов между противостоящими сторонами состояла в том, что данные усилия способствовали урегулированию конфликта эффективнее, чем любые официальные переговоры.

\section{1. Народная дипломатия: походы к формулированию дефиниции}

Само понятие «народная дипломатия», так прочно вошедшее в нашу жизнь благодаря средствам массовой информации, до сих пор в научной литературе еще не нашло адекватного теоретического осмысления и комплексного научного анализа. Попыткой дать определение понятию «народная (гражданская) дипломатия» занимался Жорж Красовски. Изучению истории и специфики гражданской дипломатии посвящены работы М. Шумана, Г. Варнера и Л. Форестера [1].

Серьезную роль в нем призваны сыграть неправительственные организации, движения, институты, выражающие естественное устремление людей к дружбе, взаимопониманию, сотрудничеству с другими народами. Разумеется, никто не собирается отменять официальные структуры, они нужны. Но и везде, в том числе в Украине, они пока или не справляются со своими задачами, или, возможно, не хотят справляться. 
Сейчас созданы многочисленные неправительственные объединения, действующие по принципам и в интересах гражданского общества. Организация Объединенных Наций тоже со своей стороны стремится двигаться навстречу этой народной силе. Например, при $\mathrm{OOH}$ функционирует Группа видных деятелей по вопросу отношений между $00 \mathrm{H}$ и гражданским обществом. Одна из ее целей - выработка предложений по усилению взаимодействия между Организацией и гражданским обществом, включая парламентариев и частный сектор.

У народной дипломатии много дел и на глобальном, и на локальном уровне. Украина не исключение, а красноречивое подтверждение сказанного.

На данный момент в разных странах, в том числе и в Украине, есть граждане, которые так и поступают. Они стремятся влиять на жизненно важные сферы внешней и внутренней политики своих правителей, на все, что касается вопросов самосохранения, достойного сегодняшнего дня и еще более лучшего будущего [2].

Своим поведением всегда стараюсь выразить сочувствие при виде несчастья другого человека, будь он даже врагом. Стараюсь для людей делать то, что способствует укреплению дружбы и усилению патриотизма в обществе.

Таким образом, общественная дипломатия - это своего рода форма ответа на глобальные вызовы и угрозы, на становление нового мирового порядка, на ход внутриполитического развития. Неслучайно она стала более актуальной в эпоху глобализации, глубоких общественных изменений и стремительного развития цивилизаций. Дружба - как спокойная и тихая привязанность, направляемая и укрепляемая привычкой, возникающей из долгого общения и взаимных обязательств, укрепляет лишь достойных людей.

Эти неравнодушные, по большому счету мудрые люди [3] и составляют так называемую народную (гражданскую) 
Права людини в Україні та у зарубіжних країнах:

проблеми теорії та нормативно-правової регламентації

дипломатию, которая известна еще со времен Римской империи.

Рассмотрение этого явления начнем с внешнего, межгосударственного или межнационального аспекта.

«Хочется рассказывать о своем пребывании в Украине, о людях и событиях, которые сыграли судьбоносную роль не только в моей жизни, но и в истории украинского и азербайджанского народов, а также других государств, с которыми у меня всегда были теплые взаимоотношения. Человек есть центр и цель своей жизни.

Вспоминается сентябрь 1989 года. Нас, офицеров запаса Советской Армии, собрали со всех уголков Советского Союза в Киеве для прохождения двухмесячных курсов переподготовки. Разместили в здании Суворовского училища и, как тогда было принято, спальные помещения отвели людям разных национальностей. Так судьба свела меня с тогдашним харьковчанином Евгением Кушнаревым.

В день поселения мой товарищ по комнате был очень грустным. Я, немного повременив, обратился к нему с вопросами: «Почему вы так грустны? Что-то случилось? Мы же пока ничего не знаем друг о друге, давайте познакомимся, расскажем о себе, о семьях, о работе». Мой собеседник - а жить в одном помещении нам предстояло два месяца - ответил, что, мол, ему неоднократно рассказывали, какие азербайджанцы «грубые», «некультурные», «головорезы» и прочее, но он этому не верил, поскольку ранее лично никогда не общался непосредственно с азербайджанцами из Баку, и вот теперь будет такая возможность...

В тот же первый вечер все съехавшиеся офицеры запаса собрались, как это было принято, за круглым столом, накрытым тем, что каждый захватил из дома. Застольная беседа, тосты, различные высказывания и мнения словом, сложилась веселая компания, и разговор постепенно перешел на «азербайджанскую тему». Много вопросов было задано мне - «лицу кавказской национальности». И многое было сказано сидящими за 
столом о положении на востоке, на Кавказе и так далее. Постепенно очередь высказаться дошла и до моего соседа по комнате. Помню, он задумался, а потом неожиданно выложил на стол несколько бумаг, содержащих информацию об Азербайджане и непосредственно о событиях в Сумгаите. Евгений Петрович тогда сказал, что эту информацию ему передал один из нас - приехавший на сборы офицер запаса, представитель одной из кавказских национальностей. Евгений Петрович, хорошо помню, спокойно прочел все, что было в указанных бумагах. А в них речь шла о том, какие азербайджанцы «звери», «дикари» и как они себя вели в Сумгаите. Мы все внимательно выслушали эту информацию... Евгений Петрович долго смотрел в мою сторону, а потом спросил: «Неужели же азербайджанцы такие? Что скажешь?..»

Я был немного обижен и задал ему встречные каверзные вопросы: «Знаешь ли ты лично кого-то состоятельных людей других национальностей, которые потеряли свое имущество в результате известных событий в Сумгаите? Как считаешь, почему многие еще задолго до этого покинули город, массово снимая деньги со сберегательных книжек? Кто, по-твоему, является организатором погромов, и кто стоит за сумгаитской провокацией? Кому было выгодно подготовиться и уже на следующий день показать фото, видео материалов по этому событию в европейских городах, «рекламировать» Азербайджан и сумгаитские события?»...

Мы до поздней ночи говорили о спекуляции политиков на этой теме, обсуждали ситуацию в Азербайджане, в том числе и в Сумгаите, неправдивое изложение событий в центральной прессе.

Видя неподдельную заинтересованность Кушнарева, я тогда отметил для себя, что он умеет выслушивать людей и объективно анализировать различные точки зрения. Кушнарев тогда мне показался человеком, который способен из огромного потока информации сделать свои собственные выводы и который не пойдет на поводу у чужих амбиций и мнений [4]. 
Права людини в Україні та у зарубіжних країнах:

проблеми теорії та нормативно-правової регламентації

Еще в начале века во время учёбы в Национальной академии государственного управления при президенте Украины один профессор мне сказал: «Азербайджан отсталая и тоталитарная страна, демократии там вообще нет...». На мой вопрос: «Вы были в Азербайджане?» он ответил: «Нет...». Мы договорились подготовить аргументы для обсуждения этого вопроса.

Через две недели после нашей следующей встречи, на которой я высказал свои аргументы по вопросу демократи в Азербайджане, профессор пригласил меня к себе и сказал: «Ты меня этим национальным вопросом воспитал, я твои материалы отдал в журнал «Политика и культура», попросил редактора встретиться с тобой, если будут какието правки, чтобы потом все это напечатать в журнале». Материал был напечатан на украинском языке 11 сентября 2000 года во всеукраинском еженедельном журнале «Політика і культура» под названием: «Батько нації або Чому мудрий азербайджанський народ звернувся 3 проханням до Гейдара Аліева взяти на себе відповідальність за порятунок республіки» («Отец нации или Почему мудрый азербайджанский народ обратился с просьбой к Гейдару Алиеву взять на себя ответственность за спасение республики»). Эта статья также была переведена и напечатана в азербайджанских газетах «Азербайджан», «Бакинский рабочий», «Халг газети» и другие [5].

Отметим попутно вот что. Неправительственные дипломаты работают в некотором смысле в более упрощенных, а в чем-то более трудных условиях. Конечно, им не приходится путаться в тонкостях дипротокола, в нюансах дипэтикета. Это плюс, но не абсолютный, поскольку многие вещи они должны знать не хуже мидовских работников: культурные, бытовые, религиозные обычаи, разные пристрастия и табу другой стороны. К сожалению, у народных дипломатов нет официального финансирования. Это минус. Им надо рассчитывать на свои силы или на богатых и неравнодушных к людским бедам спонсоров. У народных дипломатов нет и знаменитого 
дипиммунитета. Это опять же минус. Хотя, если уж говорить честно, то, по большому счету, его нет и у официальных государственных дипломатов. Да, когда все более или менее спокойно, когда все протекает по известным правилам и канонам, иммунитет работает. Но когда имеешь дело с террористами, с людьми без правил и привычных понятий о гуманности и сдержанности, у тебя нет никаких гарантий и иммунитетов.

Бывали и более тяжелые теракты против дипломатов с большими жертвами. Из недавней истории можно отметить подрывы посольств США в Кении и Танзании в 1998 г., когда погибли более 200 человек. Только за последние 20 лет прошлого века при разных обстоятельствах в западных странах убит 21 турецкий дипломат [6]. В 2003 г. при подрыве иорданского посольства в Багдаде погибли 17 человек. К подобным варварским актам можно смело отнести и американскую ракетную атаку против китайского посольства в Белграде во время наглого, абсолютно незаконного вооруженного нападения США и их союзников на Югославию в 1999 г. тогда в посольстве были убиты 3 человека и 20 были ранены. «И так далее» - вынуждены мы сказать, зная, что эти черные списки неполные, и понимая, что, скорей всего, они могут иметь продолжение [7].

C тех пор как закончилась «холодная война» (так, во всяком случае, утверждают многие государственные деятели), народная дипломатия прочно заняла свое место в налаживании отношений между неправительственными организациями и отдельными гражданами, между целыми странами. Популярны гражданские международные проекты познавательной направленности. Поиском партнеров за рубежом занимаются музыканты, врачи, журналисты, представители многих других профессий, существуют разные фонды гуманитарных инициатив, действуют даже центры детской народной дипломатии, где дети учатся тонкостям этой профессии, умению общаться и понимать других. 
Права людини в Україні та у зарубіжних країнах:

проблеми теорії та нормативно-правової регламентації

Опыт мирового общественного развития, особенно в условиях глобализации, показал, что оголтелый национализм, перерастающий в шовинизм, а также все виды сепаратизма, экстремизма и терроризма, эксплуатирующие идею права нации на самоопределение, в действительности не позволяют ни одному народу реализовать свои подлинно национальные интересы [8].

Наполеон как-то заметил: «Народ без религии - жалкий корабль без компаса. Без религии человек ходит во тьме. Только религия указывает человеку на его начало и конец». Поэтому духовные и душевные качества человека особенно важны для развития его умственной деятельности. Мои земляки в этом отношении благодарны Духовному управлению мусульман Украины во главе с высшим духовным лицом мусульман - муфтием (лицом, имеющим право решать религиозно-юридические вопросы. - Aвт.) Украины, шейхом Ахмедом Тамимом.

Признанием важности деятельности этого института является тот позитивный заряд, который стимулирует еще более активную работу в деле нравственного воспитания мусульманских братьев и сестер на благо украинской государственности. Подтверждение этому - участие уважаемого Ахмеда Тамима в одном благородном деле - в организации Управлением мусульман Кавказа, Государственным комитетом по работе с религиозными образованиями, Национальной Академией Наук Азербайджана и Бакинским международным центром мультикультурализма Международной конференции на тему «Исламская солидарность призыв времени». В своих выступлениях Ахмед Тамим отмечал важность правильной пропаганды исламских ценностей, недопустимость политизации религии, говорил о вреде, наносимом исламским ценностям в социальных сетях.

23 ноября 2018 г. во Дворце «Украина» в Киеве состоялся VI Съезд мусульман Украины с присутствием 3344 делегатов со всей страны под девизом «Духовность. Единство. Патриотизм», на котором были отмечены все свои достижения за 26 лет. 
Важно отметить, что представители национальных меньшинств составляют 25\% от всего населения Украины, а количество мусульман - около 2 млн человек.

В первой (рабочей) части заседания Съезда делегаты обсуждали положение мусульман Украины, их потребности, пути развития и существующие проблемы, в том числе и вопрос строительства мечетей, просветительских центров, выделение земли для мусульманских кладбищ. В итоге было решено:

- продолжить курс противодействия и осуждения деструктивной деятельности сект, организаций и отдельных лиц, направленных на разрушение мусульманского сообщества, защищать украинское общество от экстремистских движений и распространения их разрушительной деструктивной идеологии;

- налаживать контакты с общественными, государственными организациями, журналистами и так далее. Разъяснять правильно информацию об Исламе, развеивать мифы и стереотипы для налаживания диалога сотрудничества, понимания, объективности без предвзятого отношения и страха по отношению к мусульманам;

- продолжить работу над исправлением общественного мнения и опровержением ложной информации об Исламе и мусульманах;

- развивать и совершенствовать систему исламского религиозного образования и популяризировать религиозное наследие;

- уделять еще больше внимания повышению квалификации имамов, как в религиозных вопросах, так и в организационных;

- разработать новые подходы для распространения истинных знаний об Исламе и найти новые каналы распространения;

- укреплять сотрудничество с ведущими отечественными и зарубежными исламскими и исламоведческими научно-образовательными центрами; 
- углубить сотрудничество со светскими вузами, организовывать совместные проекты и исследования;

- продолжить курс противодействия и осуждения политизации религии;

- продолжить работу по сохранению единства украинского народа и неделимости государства;

- расширить участие мусульман в экономическом развитии Украины;

- открывать новые школы при общинах, оказывать поддержку, необходимую для их функционирования;

- ускорить строительство главного здания Исламского университета в Киеве;

- обеспечить общины помещениями для поддержки и развития духовной жизни мусульман;

- запланировать покупку и строительство молитвенных домов, мечетей, открытие культурнопросветительских центров, а также центров социальной адаптации мигрантов и переселенцев;

- продолжить отстаивать право на выделение земельных участков на кладбищах для погребения мусульман согласно канонам Ислама в Киеве и других городах;

- активизировать социальную и благотворительную деятельность местных мусульманских религиозных общин;

- подготовить кадры в сфере капелланской работы, как среди военнослужащих, так и в местах лишения свободы, и в медицинских учреждениях;

- уделять больше внимания патриотическому воспитанию среди мусульман, особенно среди молодежи.

Было зачитано приветственное слово Президента Украины, который высоко оценил работу дУМУ на пути развития государства, защиты страны и единства украинского общества. Лично поздравили мусульманскую общину Дуаен дипломатического корпуса Украины, Посол Туркменистана Турберди Аманмурадов, Посол Индонезии Юдди Криснанди как представитель многочисленной 
мусульманской страны, Председатель комитета Верховной Рады по вопросам здравоохранения Ольга Богомолец, экспредседатель Службы внешней разведки Украины Николай Маломуж, сенатор Европейского экономического сената Светлана Подлесная. От имени ВСЦиРО выступил епископ Римско-католической церкви Виталий Кривицкий. Первый заместитель Секретаря Совета национальной безопасности и обороны Украины Михаил Коваль выразил свою поддержку Духовному управлению мусульман Украины и шейху Ахмеду Тамиму лично.

Солидарность исламских стран является очень важным фактором создания гуманитарных отношений - это обеспечивает мультикультурализм и стабильность в обществе [9].

\section{2. Глобализация концепции народной дипломатии}

В условиях современного мирового развития многие привычные понятия и явления приобретают новый смысл и требуют детального изучения и переосмысления. Не является исключением и понятие «народная дипломатия», которая стала сегодня важной составляющей официальной дипломатии и существенным фактором мировой политики.

Многие эксперты отмечают, что в стремительно развивающемся мире этот вид дипломатии превратился в «новую силу глобализации», поскольку объективные процессы демократизации и глобальной информатизации привели к значительному повышению политической роли гражданского общества на международном уровне. В современном государстве уже невозможно представить политический процесс без активного участия институтов гражданского общества. Зачастую именно на уровне неправительственных структур и организаций генерируются многие идеи, которые затем становятся предметом межгосударственного сотрудничества. 
Из зарубежных исследований, дающих различные теоретические обоснования роли гражданской дипломатии в современном мировом политическом процессе, следует назвать работы П. Симмонса, А. Джеймса, Дж. Розенау, С. Брауна, Т. Принсена и М. Фигнера, Б. Хокинга, М. Бермана, Дж. Джонсона, М. Гулдинга [10].

Понятие народной дипломатии еще недостаточно изучено учеными-международниками. Несмотря на то, что в современной научной литературе существуют различные определения, однако терминологического единства пока нет. Так, наряду с понятием «народная дипломатия» используются такие термины, как «публичная дипломатия» и «общественная дипломатия».

Термин «публичная дипломатия» был введен в научный оборот деканом Школы права и дипломатии Университета Тафта Эдмунтом Галлионом в 1965 году. Классическое определение публичной дипломатии включает «программы, финансируемые правительством, направленные на информирование и оказание воздействия на общественное мнение в других странах» [11].

У народной дипломатии много дел. Самые неотложные дела - в зонах конфликтов. В мире таких много, некоторые были уже перечислены. Немало их и на Кавказе, и люди видят, что государственные, правительственные органы не справляются. Сейчас уже ясно, что без участия неправительственных организаций, без самих граждан большинство из этих конфликтов не остановить, или процесс займет слишком много времени, а, как мы знаем, в таких точках каждый день и час происходят новые драмы и трагедии.

Например, в армяно-азербайджанском нагорнокарабахском конфликте в 1993-94 гг. Советом безопасности ООН были приняты четыре резолюции по освобождению нагорно-карабахского региона и других семи районов, оккупированных территорий Азербайджана [12], однако до сих пор это остается лишь на бумаге. 
Для урегулирования конфликта Азербайджан всегда выступал за контакты и сотрудничество между армянской и азербайджанской общинами Нагорного Карабаха.

Учитывая данные по Азербайджану и Армении, не говоря уже о Нагорном Карабахе, который пребывает вообще в полуразрушенном состоянии. Правовые механизмы пока не срабатывают, другого выхода нет. Однако весь процесс должен быть тщательно проработан по требованиям международного права, так как всегда найдутся провокаторы. Чтобы дать отпор таким провокаторам, инициирую в рамках «челночной дипломатии» (Челночный маршрут (перен.: о регулярном движении транспорта между двумя пунктами на короткий дистанции) [13], послы Азербайджана и Армении в России дважды посетили Нагорный Карабах, Ереван и Баку. Философия тут очень простая: невозможно просто взять свою территорию и улететь вместе с ней на Марс или Луну. В любом случае народной дипломатии нужно находить общий язык со своими соседями, и чем быстрее, тем лучше. Это будет на благо экономики и на благо простых людей... [14]

У народной дипломатии есть масса средств, которые существуют давно и независимо от нее, которые нравятся людям, которым люди доверяют. Пожалуйста, используй их, они для добрых дел и существуют. Литература, театр, кино (все это, правда, с оговорками), футбол, хоккей, шахматы и другие виды спорта, народное творчество, наука, музыка, туризм и так далее - любой может продолжить этот список. Практически все перечисленное входит в обширнейшее понятие - культура.

Именно культура является самым эффективным и многофункциональным инструментом для зашивания региональных ран, успокоения болевых точек, соединения разорванных частей народов, для сведения их, в конечном счете, в единое целое под названием «Мудрое и Гуманное Человечество». Это уникальное явление - культура заслуживает более подробного рассмотрения. 
Права людини в Україні та у зарубіжних країнах:

проблеми теорії та нормативно-правової регламентації

\section{3. Культурная основа народной дипломатии}

Культура - это наивысшее достижение человечества. Она может объединить все народы, возбудить у них чувство глубокого уважения друг к другу, отвлечь их от разного рода национальных, шовинистических, расистских противоречий и столкновений, от разрушительных, низменных процессов, насаждаемых теми, кто привык «ловить рыбу в мутной воде».

К сожалению, в наше время по-прежнему остается популярным (вольно или невольно) одно древнее международное занятие - культивирование взаимного непонимания и неприязни. Плоды его попробовали многие народы и, похоже, остались недовольны.

Практически не вызывает сомнения, что в обществе, где на пьедестал высших ценностей вознесена культура, не может быть места для терроризма и экстремизма. Именно культура, по нашему глубокому убеждению, должна сыграть решающую роль в сплочении гражданского общества, в мобилизации духовного и творческого потенциала народа.

Известно, например, что на культуру сегодня тратится менее одного процента расходов бюджета, а на преодоление последствий бескультурья (на содержание тюрем, на финансирование силовых структур милиции, спецслужб и так далее) - уже почти треть бюджета. Собственно говоря, организованная преступность, терроризм, массовые нарушения закона - это, в сущности, проявление бескультурья в широком его смысле. Чем меньше культуры, тем больше расходов на безопасность.

Сейчас одна из серьезнейших угроз миру, уже не раз помянутая недобрым словом, - терроризм [15].

Не подвергая ни малейшему сомнению необходимость жестких силовых мер против проявлений экстремизма и терроризма, приходится констатировать: одними силовыми методами террор победить невозможно [16]. Эта истина становится все более очевидной. Вторжение 
США в Ирак и Афганистан, и другие силовые методы не принесли мира этим регионам.

Так или иначе, любое проявление терроризма - это искаженное восприятие человеком духовно-нравственных ценностей и ориентиров. И, конечно, если отечество правильно воспитывает людей, то и преступников оказывается гораздо меньше. Самый эффективный метод воспитания - культура.

Повторим: с терроризмом нужно и можно бороться не только пушками. Можно и нужно достигать мира через духовность, через культуру.

Наполеон Бонапарт писал [17], что духовная сила относится к физической силе как три к одному. Так хочется, чтобы эта формула заработала в нашей искаженной действительности, чтобы выросла наша упавшая духовная, культурная мощь. Само по себе это не произойдет. Мы должны приложить много усилий.

Специалисты в области культуры утверждают, что речь должна идти о целостной программе конкретных практических действий, объединяемых понятием «антитеррористическая социально-культурная инженерия». Пришло время начать ее разработку, а затем и широкое внедрение. Речь, прежде всего, идет о создании современных, высокоточных средств социально-культурного влияния, способных реально воздействовать на умы и сердца людей. От мирно-культурных деклараций мы должны переходить к социально-культурным, толерантным технологиям.

Инструменты, механизмы, технологии антитеррористической социально-культурной инженерии должны органично встраиваться в действующее антитеррористическое, антикриминальное законодательство и играть все возрастающую роль в практике борьбы с экстремизмом, терроризмом, наркоманией, преступностью.

Огромным полем, с которого экстремистские лидеры пожинают урожай, является детская беспризорность. Их ждет тяжелое будущее - тюрьма, гибель в притоне или от 
наркотиков. Но еще страшнее - стать зомбированными послушниками террористов. Наше общее жестокое безразличие к таким детям, из судеб которых сложится судьба Украины через 10-15 лет, - есть крайне опасный и тревожный показатель духовно-нравственного состояния общества.

Уже давно пора создать международный центр по объединению усилий мирового сообщества в деле воспитания человека будущего, человека-созидателя.

В этом деле следует максимально использовать средства массовой информации как возможный колоссальный инструмент консолидации всего общества. СМИ вообще теперь уже ведут за собой общество, объединяя его или разрушая. Но СМИ должны сами объединиться для решения важных и благородных задач [18]. Им необходимо шире пропагандировать культуру народов, достижения в различных областях науки и техники, принципы дружбы, сотрудничества, созидания открытости, честности, взаимовыручки, сострадания к чужому горю и такое прочее.

Настало время создать международный информационный канал по типу «Радио Свободы», но не американский, не немецкий и не английский, а общенародный под возможным названием «Эхо планеты» (название можно придумать - было бы желание). Цель такого центра объединение людей во имя сохранения мира, культуры и улучшения жизни на земле.

Еще великий Сократ говорил: «Не спеши осуждать, спеши понять» [19]. Общеизвестно, что воспитание терпимости, толерантности к «чужим» является одной из самых важных проблем в наступившем веке. Если это чувство не будет выработано в самых широких массах, по сути дела - у каждого жителя Земли, нашу цивилизацию, в условиях неизбежного и все нарастающего смешения народов, ожидает череда неразрешимых конфликтов. Ксенофобия сегодня занимает такое же место, как геополитические, безумные амбиции в XX веке (борьба за «расширение жизненного пространства»), которые 
привели, в частности, Германию к двум мировым войнам. Сегодня ксенофобия - исходящая и от больших, и от малых народов, от представителей всех конфессий и культур, может обернуться «войной всех против всех» в любом многонациональном государстве. Поэтому жизненно необходимо неустанно показывать, напоминать, разъяснять, чем заканчивается национальная нетерпимость, к какому «окончательному решению» она с логической неизбежностью приводит.

В наши дни простой смертный может легко стать представителем своей страны, поскольку улицы больших городов часто полны иностранных гостей - мужчин, женщин и детей. Так что и наши улицы предоставляют нам международный уровень общения, автоматически дают нам роль народных дипломатов. А уж когда ты выезжаешь за рубеж в командировку, как турист или спортсмен, или по обмену, на учебу, в иностранную семью пожить, посмотреть, себя показать, ты настолько ответствен за свои действия, за свой культурный уровень, что лучше тебе как следует поработать над собой заранее. Кстати, в советское время этому уделялось колоссальное внимание. Даже были органы, которые занимались проверкой интеллектуального, информационного багажа человека, отъезжающего за рубеж, и какой-то смысл в том был, хотя и перегибов хватало.

Из истории известно, что формирование землячества на территории «постороннего» государства и укоренение там - дело достаточно непростое. Вспомним, как осваивали Америку в конце XIX века итальянцы. Потомков Данте и Рафаэля американские обыватели даже отказывались считать белыми людьми. Итальянцев использовали в качестве чернорабочих на строительстве дорог, рытье канав, и далее везде, где побрезговал бы работать натуральный американец. C криками: «Проклятые макаронники!» - местные националисты-хулиганы врывались в мелкие итальянские лавочки и мастерские и учиняли разрушительные погромы, а над владельцами заведений и посетителями - итальянцами - по малейшему 
поводу, а чаще всего и без него, изощренно издевались и били. В ответ на столь неучтивое обращение итальянцы постепенно начали объединяться в дружные коллективы, после чего насмехаться над ними, а тем более бить их стало рискованно. Ну а после того, как в Соединенных Штатах на основе вышеупомянутых коллективов появилась организация, получившая широкую известность под названием «итальянская мафия», развлекаться за счет «макаронников» стало самоубийственно опасным. Число любителей позабавиться и обогатиться за счет «итальяшек» резко сократилось, почти до нуля. А уцелевшие отставные погромщики и хулиганы научились с наступлением ночи наслаждаться тихой радостью. Радость эта возникала от сознания того, что им чудесным образом удалось остаться целыми и невредимыми, вне поля зрения злопамятной, как беременная слониха, вездесущей итальянской мафии. Большинству итальянцев в США довелось пройти тяжелые испытания, но сегодня, спустя многие десятилетия, лучшая часть итальянской диаспоры по праву и справедливости воспринимается во всем мире как цвет американской культуры, политики и экономики. А итальянская диаспора, в целом оставаясь неразрывной живой частью итальянской нации, давно уже стала равноправным и полезным субъектом американского общества.

Сегодня, по оценке американских экспертов, с похожим на блестящий результат итальянцев прошли в США свой поначалу тернистый, порою мучительный и унизительный путь на политическую и финансовую вершину и некоторые другие диаспоры: ирландская, китайская и польская. Остальные - их много - преимущественно благоденствуют, подсчитывают свои доходы и терпеливо набираются опыта. Арабы, армяне, африканцы, индийцы, мексиканцы, турки, японцы, представители других народов мира (всехне перечислишь) варятся в общем американском котле. А страны, откуда они приехали, тоже довольны, регулярно получая по ходу этого беспрерывного процесса 
свои дивиденды в виде денег, квалифицированных специалистов, а также привилегии в виде доступа к высоким технологиям, разработанным в наиболее развитой стране мира.

Похожая картина, те же проблемы наблюдаются в Западной Европе. И здесь тоже с удовольствием и улыбкой встречают состоятельных туристов и людей с дипломатическими паспортами. Ко всем пришлым поначалу относятся настороженно, со скрытым недоверием. К сожалению, это естественно. Зародыши ксенофобии дремлют в людях чуть ли не с первобытных времен, когда появление чужаков воспринималось как сигнал смертельной опасности. В современном мире ксенофобии не подвержены в основном люди с высокой душевной организацией и достаточно развитым интеллектом. А такие люди везде в меньшинстве. Тем не менее, во всех странах Западной Европы приезжих, остающихся на постоянное жительство, очень много, и с каждым днем их число увеличивается. И причина этому явлению одна - трудоспособные приезжие нужны и страны пребывания без них уже не могут обойтись.

Сплоченная диаспора отзывается на международные события и способна формировать объективное мнение окружающих о своей родине. Не стоит скидывать со счетов и дополнительные внешнеполитические рычаги, чья конкретная мощность в каждом отдельном случае пропорциональна весу и влиянию, которых добилась соответствующая диаспора [20].

\section{Выводы}

В этом наша принципиальная позиция, наша народная (гражданская) дипломатия: мы хотим, чтобы представители разных стран, со своими особенностями, со специфическими проблемами и целями, с разным экономическим и военным потенциалом прониклись уважением и дружелюбием друг к другу. 
Права людини в Україні та у зарубіжних країнах:

проблеми теорії та нормативно-правової регламентації

Таким образом, законность, действенность и способность института народной дипломатии адекватно реагировать на сложнейшие вопросы современности зависит от множества факторов. В числе первых - не скорость «рыночно-демократических реформ», а сила и надежность базовых институтов страны - института президентства и так далее.

Только на основе этих чувств людей ждет безопасная жизнь, полная приятных и интересных дел.

Народная дипломатия ярко проявляется в деятельности международных неправительственных организаций. Первые такие организации были созданы в начале XIX века и представляли собой профессиональные, просветительские, религиозные, пацифистские организации. Они играли активную роль во всех аспектах современных международных отношений [21]. Более того, в ряде областей они являются лидерами. В частности, Международный институт по гуманитарному праву (создан в 1970 г.) регулярно созывает семинары по обучению офицеров законам и обычаям войны и нормам, направленным на защиту беженцев. Ассоциация международного права (создана в 1873 г.) координирует исследования по актуальным проблемам международного публичного и международного частного права, уделяя внимание исследованиям в области коллизионного права и права договоров. Международная ассоциация по уголовному праву (создана в 1924 г.) разрабатывает принципы применения конвенций по международному уголовному праву и так далее [22].

«Политика - слишком важное дело, чтобы его полностью отдавать политикам». Примерно так звучит один весьма актуальный сегодня афоризм. Понимать его следует максимально широко. Во-первых, то же самое можно сказать почти обо всех сферах человеческой деятельности, например о культуре и ее чиновниках, об официальной дипломатии и так далее. Во-вторых, он обращен ко всем нам, гражданам любого государства. 
Народная дипломатия ярко проявляется в деятельности международных неправительственных организаций. Первые такие организации были созданы в начале XIX века и представляли собой профессиональные, просветительские, религиозные, пацифистские организации. Они играли активную роль во всех аспектах современных международных отношений. Более того, в ряде областей они являются лидерами. В частности, Международный институт по гуманитарному праву (создан в 1970 г.) регулярно созывает семинары по обучению офицеров законам и обычаям войны и нормам, направленным на защиту беженцев. Ассоциация международного права (создана в 1873 г.) координирует исследования по актуальным проблемам международного публичного и международного частного права, уделяя внимание исследованиям в области коллизионного права и права договоров. Международная ассоциация по уголовному праву (создана в 1924 г.) разрабатывает принципы применения конвенций по международному уголовному праву и так далее.

В последнее время сильно выросла роль неправительственных организаций в международных отношениях. Активное их участие в урегулировании современных конфликтов предопределяет, по крайней мере, две их основные характеристики: во-первых, это огромная численность неправительственных организаций; во-вторых, это - широкое разнообразие их деятельности. Неправительственные организации сегодня занимаются самыми разными проблемами современного общества. Крайнее разнообразие лиц, задействованных в работе неправительственных организаций (эти люди говорят на разных языках, имеют различный социальный статус и разный уровень и профиль образования), позволяет им достаточно быстро находить общий язык и устанавливать необходимый контакт с населением конфликтных районов, а также с представителями враждующих сторон. Декларируемый нейтралитет и независимость от государственных структур многих из неправительствен- 
ных организаций также предопределяет особое доверие к ним со стороны гражданского населения.

Таким образом, народная дипломатия вмещает в себя всю многообразную деятельность по взаимодействию с гражданским обществом и аудиториями зарубежных стран, дает уникальный инструментарий для расширения международных общественных связей государства.

\section{Список использованных источников:}

1. Shuman M., Warner G., Forest L. Citizen Diplomacy: What it is, how it began, and where it's going. 1987. P. 35. URL: http://www.context.org/ICLIB/IC15/Shuman.htm

2. Гулієв А.Д. Необхідність інституту народної дипломатії для формування громадянського суспільства в Україні та інших посткомуністичних країнах. Розвиток громадянського суспільства: Духовність і право: III міжнар. наук, конф., 25-27 вересня 2010 р. Львів, 2011. С. 92-99.

3. Кушнарёв Е.П. Конь рыжий. Записка контрреволюционера / Кушнарев Е.П. Харьков, 2005. 280 с.

4. Гулиев А.Д. Наука и народная дипломатия. Харьков : Факт, 2019. 240 с.

5. Гулиев А.Д. Батько нації або Чому мудрий азербайджанський народ звернувся 3 проханням до Гейдара Аліева взяти на себе відповідальність за порятунок республіки. Політика і культура. 2000. 11 вересня.

6. Малевил Ж. Армянская трагедия 1915 года. Баку : Элм, 1990. С. 7.

7. Алексеев И.С. Искусство дипломатии: не победить а убедить / Алексеев И.С. Москва : Из-во «Дашков и К», 2007. $284 \mathrm{c}$.

8. Алиев И.Г. Выступление на Дне годовщины Азербайджанской армии. Бакинский Рабочий, 26 июня 2010 г.

9. Гулиев А.Д. Наука и народная дипломатия. Харьков : Факт, 2019. 240 c. 
10. Goulding M. Globalization and the UN: new opportunities, new demands. International Relations. 1999. April. V. XIV. № 4.

11. Гаджиев К.С. Имидж как инструмент культурной гегемонии. Мировая экономика и международные отношения. 2007. № 12. С. 6.

12. Садыхов

$\Phi$.

Дипломатическая

служба Азербайджана: политические приоритеты, этапы формирования. Баку, 2004. С. 183.

13. Попов В.И. Современная дипломатия: теория и практика. Дипломатия - наука и искусство: курс лекцій. Москва : Международные отношения, 2004.576 с.

14. http://www.day.az посмотрено 07 июня 2010 г.

15. Антипенко В.Ф. Поняття тероризму (кримінальноправове визначення). Право України. 1999. № 2. С. 92-95.

16. Гулієв А.Д. Порівняльно-правовий аналіз ролі інституту президентства у протидії міжнародному тероризму (на прикладі України та Азербайджанської Республіки) : автореф. дис. на здобуття науков. ступеня доктора юрид. наук. Київ, 2012. С. 36.

17. Манфред А.З. Наполеон Бонапарт. Москва : Мысль, $1973.775 \mathrm{c}$.

18. Кодекс Народного дипломата. Київ : УАІД «Рада», 2012. 56 c.

19. Таранов П.С. Анатомия мудрости. 120 философов : в 2-х т. Симферополь : Таврия, 1996. Т. 1.624 с.

20. Ибрагимбеков М. Балтиморский скунс. Баку, 2007. $246 \mathrm{c}$.

21. Тимченко Л.Д. Международное право. Харьков : Консум ; Ун-т внутр. дел, 1999.

22. Международное публичное право / отв. ред. К.А. Бекяшев. Москва, 2004. 
Права людини в Україні та у зарубіжних країнах:

проблеми теорії та нормативно-правової регламентації

DOI https://doi.org/10.36059/978-966-397-210-7/136-160

Денисов В. Н.,

доктор юридичних наук, професор, член-кореспондент

Національної академії правових наук України, заслужений діяч науки і техніки України, завідувач відділу міжнародного права

та порівняльного правознавства

Інституту держави і права імені В. М. Корецького

Національної академії наук України,

м. Київ

\section{Фалалеєва Л. Г.,}

кандидат юридичних наук, доцент, старший науковий співробітник відділу міжнародного

права та порівняльного правознавства

Інституту держави і права імені В. М. Корецького

Національної академії наук України,

м. Київ

\section{ГРОМАДЯНСЬКІ ПРАВА ЛЮДИНИ КРІЗЬ ПРИЗМУ ВІДСТУПУ УКРАЇНИ ВІД ЗОБОВ' ЯЗАНЬ В УМОВАХ ЗБРОЙНОГО КОНФЛІКТУ ТА ТИМЧАСОВОЇ ОКУПАЦІЇ ЧАСТИНИ ЇЇ ТЕРИТОРІЇ}

Анотація. Удослідженні висвітлено громадянські права людини в аспекті міжнародно-правових засад регулювання відступу від зобов'язань під час суспільної небезпеки, яка загрожує життю нації. Проаналізовано практику використання відступу від зобов'язань у сфері громадянських прав людини Украӥною, до якої вона вперше вдалася в умовах збройного конфлікту та тимчасової втрати контролю над частиною державної території. Розкрито сутність, чинники, механізми, особливості та проблеми, пов'язані з відступом від 
зобов'язань у сфері прав людини, інструменти його реалізації. Підкреслено значення застосування відступу від зобов'язань у сфері громадянських прав людини як одного із запобіжників для держави, її право, що має винятковий характер, можливість реалізації якого передбачена відповідним міжнародним договором, вимагаючи дотримання узгоджених умов і процедур. Здійснено порівняльний аналіз положень Міжнародного пакту про громадянські та політичні права 1966 р., Конвенції про захист прав людини та основоположних свобод 1950 . щодо права держави на відступ від окремих зобов'язань під час суспільної небезпеки, яка загрожує життю нації. Наголошено, що відступ від зобов'язань у сфері громадянських прав людини потребує всебічного доктринального осмислення як різновид правомірних обмежень у визначених межах застосування обмежень цих прав.

Охарактеризовано заходи, до яких була вимушена вдатися Україна задля застосування відступу від міжнародно-правових зобов'язань у сфері прав людини в умовах збройного конфлікту та тимчасової окупації частини державної території, а також проаналізовано позицію щодо цих заходів акторів, які відіграють провідну роль серед суб'єктного складу міжнародного співтовариства як політико-правової спільноти, - Організації Об'єднаних Націй та Ради Європи.

\section{Вступ}

На території України сьомий рік поспіль триває збройний конфлікт, під час якого грубо і систематично порушуються права людини цивільного населення, що актуалізує необхідність розширення можливостей дотримання міжнародних стандартів та розбудови спроможності виконання міжнародних договірних зобов'язань у сфері захисту, inter alia громадянських прав людини, дотримання норм міжнародного права прав людини. В умовах збройного конфлікту, тимчасової окупації частини державної території, нових геополітичних реалій Україна як держава - учасниця багатьох міжнародних договорів про захист прав людини, вимушена 
реалізувати своє право, скориставшись гнучкістю застосовуваних правових рамок і вдавшись до практики відступу від окремих договірних зобов'язань у сфері громадянських прав людини. У такій ситуації фактично йдеться про відступ від зобов'язань (дерогацію, англ. derogation) як «раціональну реакцію» (англ. "rational response"), один із запобіжників, «рятівних механізмів» (англ. "escape mechanisms") для держави, себто її право, що має винятковий характер, можливість реалізації якого передбачена відповідним міжнародним договором, вимагаючи чіткого дотримання узгоджених умов i процедур.

Договірна практика Організації Об'єднаних Націй та Ради Європи спрямована на віднайдення прийнятної моделі міжнародно-правового співробітництва на універсальному та регіональному рівні відповідно. Вочевидь міжнародні договори Ради Європи сприяють гармонізації та вдосконаленню національного законодавства і практики на засадах європейських стандартів як їх «стратегічного підгрунтя» (англ. "strategic rationale"). За організаційним ефектом розрізняють, зокрема, міжнародні договори Ради Європи, що передбачають заснування механізму контролю їх виконання, визначають його повноваження ухвалювати рішення про дотримання або недотримання державами-учасницями взятих зобов'язань. У Раді Європи запроваджено дієву систему захисту прав людини, договірним осердям якої стала Конвенція про захист прав людини та основоположних свобод 1950 р. [1] (далі - Конвенція 1950 р.), що містить каталог колективно гарантованих прав людини та передбачила заснування безпрецедентного конвенційного контрольного механізму, міжнародного юрисдикційного органу їх захисту - Європейського суду з прав людини (далі- ЄСПЛ). Він не лише забезпечує виконання державами-учасницями конвенційних зобов'язань, а також тлумачить зміст положень Конвенції 1950 р. і протоколів до неї, у тому числі враховуючи винятковість права 
на відступ від зобов'язань. 3 огляду на викладене відступ від зобов'язань у сфері громадянських прав людини потребує всебічного доктринального осмислення як різновид правомірних обмежень у визначених межах застосування обмежень цих прав як складника міжнародного права прав людини, зокрема європейського права прав людини.

\section{1. Право на відступ від зобов'язань за Міжнародним пактом про громадянські} та політичні права 1966 р.

Міжнародний пакт про громадянські та політичні права 1966 р. [2] (далі - Пакт 1966 р.) і Конвенція 1950 р. містять клаузулу про відступ від зобов'язань, що підлягає застосуванню на підставі та в порядку, визначених у ст. 4 першого та ст. 15 другої відповідно. Зазначені міжнародноправові акти становлять стрижень, осердя універсальної і регіональної систем правозахисту, які, 3 одного боку, вирізняються особливостями, а з іншого - мають чимало подібного, здебільшого збігаючись [3, с. 264]. Так, п. 1 ст. 4 Пакту 1966 р. вказує та те, що під час надзвичайного стану в державі, за якого життя нації перебуває під загрозою і про наявність якого офіційно оголошується, держави учасниці цього Пакту можуть вживати заходів на відступ від своїх зобов'язань за ним лише тією мірою, якою цього вимагає гострота становища, за умови, що такі заходи не $\epsilon$ несумісними з їх іншими зобов'язаннями за міжнародним правом і не зумовлюють дискримінації винятково на основі раси, кольору шкіри, статі, мови, релігії чи соціального походження. Примітно, що ст. 15 Конвенції 1950 р. не містить вимоги офіційного оголошення про існування надзвичайного стану в державі, за якого життя нації перебуває під загрозою [про гнучкість конщепції див.: 4, с. 161-162]. Однак у висновку Європейської комісії з прав людини у справі Cyprus v. Turkey (1976) визнано, що «стаття 15 встановлює вимогу певного формального i 
публічного акту відступу від зобов'язань, такого як оголошення воєнного або надзвичайного стану, і що у випадках, коли такий акт не був оголошений відповідною високою договірною стороною, хоча не існувало обставин, які перешкоджали б їй це зробити, стаття 15 застосовуватися не може» (пар. 527) [5]. Крім того, у ст. 15 Конвенції 1950 р. умова відсутності дискримінації окремо не виписана, а розглядається ЄСПЛ як елемент принципу пропорційності [6] (рішення у справі A. and Others v. the United Kingdom (2009)). При цьому змістовне наповнення принципу пропорційності вимагає забезпечення відповідності, 3 одного боку, між обмежувальними заходами, тобто втручанням держави у реалізацію окремих прав, що не мають бути занадто обтяжливими для людини, та, 3 іншого - переслідуваною метою, її правомірністю. У п. 2 ст. 4 Пакту 1966 р. наголошено, що наведене вище положення не може слугувати підставою для будь-яких відступів від ст. 6 (право на життя), ст. 7 (заборона катувань), п. 1 та 2 ст. 8 (заборона рабства), ст. 11 (заборона позбавлення волі лише на підставі невиконання договірного зобов'язання), ст. 15 (заборона незаконного визнання винним у вчиненні будь-якого кримінального злочину), ст. 16 (право на правосуб'єктність), ст. 18 (право на свободу думки, совісті і релігії), тобто йдеться також про так звані абсолютні права, відступ від яких $\epsilon$ неприпустимим, вони не підлягають обмеженням за жодних обставин. Понад це, у п. 3 ст. 4 Пакту 1966 р. визначено, що будь-яка держава-учасниця, яка використовує право відступу, повинна негайно повідомити інші держави - учасниці Пакту, за посередництва Генерального секретаря ООН, про положення, від яких вона відступила, та про причини, що спонукали до такого рішення, а також про дату, коли вона припиняє такий відступ.

Україна 5 червня 2015 р. поінформувала Генерального секретаря ООН про стан безпекової ситуації у Донецькій та Луганській областях, що змушує органи державної влади вдатися до застосування ст. 4 Пакту 1966 р. з метою відступу 
від зобов'язань за цим міжнародно-правовим актом щодо окремих прав, гарантованих ним, а саме: права на ефективний засіб правового захисту (п. 3 ст. 2; однак відступ від зобов'язань за цим пунктом відповідно до тлумачення Комітету ООН з прав людини не допускається [7, с. 6]); права на свободу від свавільного затримання та відповідні процесуальні гарантії (ст. 9); права на свободу пересування та вільний вибір місця проживання (ст. 12); права на справедливий судовий розгляд (ст. 14); права на повагу до приватного та сімейного життя (ст. 17). Невдовзі, 27 листопада 2015 р., Україна повідомила Генерального секретаря $\mathrm{OOH}$ як депозитарія міжнародних договорів про території, тимчасово непідконтрольні йому повністю або частково, щодо яких Україна скористалась своїм правом на відступ від окремих зобов'язань за Пактом 1966 р. Однак з поданих Україною повідомлень (Verbal Notes No. 4132/28-194/501-803 від 5 червня 2015 р., No. 4132/28-194/501-1987 від 24 листопада 2015 р., No. 4132/28-194/501-1792 від 6 липня 2016 р., No. 4132/28-194/501-128 від 20 січня 2017 р. та No. 4132/23-194/501-2057 від 26 листопада 2019 р.) згідно з п. 3 ст. 4 Пакту 1966 р. окремі моменти викликали занепокоєння Управління Верховного комісара ООН з прав людини стосовно правомірності відступу, узалежненого від виконання низки конкретних вимог, закріплених у цій статті [7, с. 4]. Управління стверджує: «на основі аналізу доступної інформації правомірність відступу Уряду України від окремих зобов'язань за Міжнародним пактом про громадянські і політичні права залишається під сумнівом» $[7$, c. 10].

В окремих з 29-ти (станом на квітень 2020 р.) публічних доповідей Управління Верховного комісара ООН з прав людини щодо ситуації 3 правами людини в Україні, підготовлених за результатами роботи Моніторингової місії ООН з прав людини в Україні, наведено недоліки у реалізації Україною права на відступ від окремих зобов'язань за Пактом 1966 р., про що було повідомлено 
Генеральному секретареві 00Н. Управління Верховного комісара $\mathrm{OOH}$ з прав людини вказало на необхідність забезпечення офіційного оголошення про існування у державі надзвичайного стану (відповідно до ст. 4 Пакту 1966 р. є обов'язковою умовою для використання права на відступ від зобов'язань), за якого життя нації перебуває під загрозою, та пропорційності вжитих заходів; тривалість, територіальна дія (географічне охоплення відступу має бути чітко сформульованим) і предмет відступу мають бути чітко обмеженими гостротою становища; відступ повинен узгоджуватися 3 іншими зобов'язаннями за міжнародним правом, зокрема 3 відповідними нормами міжнародного гуманітарного права. В окремому розділі Е (пункти 61-70) Сиракузьких принципів тлумачення положень про обмеження та дерогацію Міжнародного пакту про громадянські та політичні права, ухвалених Економічною і Соціальною Радою (ЕКОСОР) ООН, зокрема зазначено, що оголошення надзвичайного стану [див.: 8] bona fide уможливлює відступ від окремих зобов'язань у сфері прав людини, втім не дозволяє ігнорувати міжнародні зобов'язання загалом, inter alia, що застосовуються в умовах надзвичайного стану згідно 3 Женевськими конвенціями 1949 р. і конвенціями Міжнародної організації праці (п. 66) [9]. Вказана Управлінням Верховного комісара ООН з прав людини інформація свідчить про наявність в Україні окремих проблем 3 виконанням договірних зобов'язань та дотриманням міжнародних стандартів захисту прав людини і цивільного населення, а також потреби в їхньому удосконаленні та конкретизації, у вжитті відповідних заходів реагування задля: забезпечення, відновлення прав жертв порушень, а також відшкодування шкоди, завданої жертвам порушень прав, і надання гарантій недопущення повторних порушень. У цьому контексті та пов’язаних 3 ним, для забезпечення відповідальності та відновлення справедливості важливе значення мають міжнародні інструменти, що стосуються сприяння встановленню 
істини, правосуддя, відшкодування шкоди і гарантій недопущення повторних порушень [10], зокрема Резолюція Генеральної Асамблеї ОOH 147 (А/Res/60/147) від 16 грудня 2005 р. Основні принципи і керівні положення про право на правовий захист і відшкодування шкоди жертвам грубих порушень міжнародного права прав людини і серйозних порушень міжнародного гуманітарного права, п. 26 (XII. «Недопущення відступу», англ. "Non-derogation") яких вказує на те, що ніщо у цьому інструменті «не має тлумачитись як таке, що обмежує певні права чи обов'язки, передбачені національним законодавством або міжнародним правом, чи допускає відступ від них» [11].

Принагідно зауважимо, що дещо інакше концептуальне бачення підстав правомірності відступу держави від окремих зобов'язань у разі надзвичайної ситуації закріплено у п. 1 ст. 27 «Зупинення дії гарантій» (курсив наш) Американської конвенції про права людини 1969 р., в якому передбачено таку можливість «під час війни, суспільної небезпеки або інших надзвичайних обставин, які становлять загрозу незалежності та безпеці державиучасниці» [12, с. 152] (курсив наш), а не «загрозу життю нації», як це визначено у п. 1 ст. 4 Пакту 1966 р. та п. 1 ст. 15 Конвенції 1950 р. Крім того, для порівняння, п. 2 ст. 27 Американської конвенції про права людини 1969 р. встановлює найбільш об'ємний перелік статей, стосовно яких зупинення дії гарантій $€$ недопустимим, недозволеним, а саме: ст. 3 (право на правосуб'єктність), ст. 4 (право на життя), ст. 5 (заборона катувань), ст. 6 (заборона рабства), ст. 9 свобода від закону "еx post facto", ст. 12 (свобода совісті і релігії), ст. 17 (права сім'ї), ст. 18 (право на ім'я), ст. 19 (права дитини), ст. 20 (право на громадянство), ст. 23 (право на участь у публічному врядуванні) [12, с. 152].

Зрештою, на державу покладається обов'язок доведення: обмежувальні заходи $є$ обгрунтовано необхідними, тимчасовими і правомірними, тобто відповідають договірному 
правовому режиму їх застосування [див.: 13, с. 676-677]. Такий режим відступу від міжнародно-правових зобов'язань у сфері громадянських, як і політичних, прав людини безпосередньо стосується національного законотворення i позначається на правозастосуванні, звужуючи обсяг деяких гарантованих прав людини порівняно з міжнародними стандартами, а також юридичні гарантії їх дотримання та національні засоби правового захисту.

\section{2. Право на відступ від зобов'язань за Конвенцією про захист прав людини та основоположних свобод 1950 р.}

Стаття 15 Конвенції 1950 р. «Відступ від зобов’язань під час надзвичайної ситуації» містить клаузулу про відступ від зобов'язань, надаючи договірним державам, за виняткових обставин, можливість обмеженого і контрольованого відступу від своїх зобов'язань із забезпечення певних прав і свобод, закріплених у Конвенції 1950 р. $[14$, c. 5]. 3 огляду на положення ст. 15 Конвенції 1950 р., підкріплені судовою практикою ЄСПЛ (рішення у міждержавних та індивідуальних справах, серед яких: Greek Case (1969); Ireland v. the United Kingdom (1978); Del Rio Prada v. Spain (2013); Hassan v. the United Kingdom (2014); Sahin Alpay v. Turkey and Mehmet Hasan Altan v. Turkey (2018); Alparslan Altan v. Turkey (2019); Kavala v. Turkey (2019) ma ін.), у виняткових обставинах за державами визнається право на відступ від їх зобов'язань забезпечити дотримання прав людини, включно і громадянських, гарантованих Конвенцією 1950 р.: на конкретній території (територіальний принцип дії права на відступ), тимчасово, в обмеженому обсязі та із застосуванням моніторингового механізму. В п. 1 ст. 15 Конвенції 1950 р. встановлено, що саме «під час війни або іншої суспільної небезпеки, яка загрожує життю нації», держава може вдатися до заходів, що $\epsilon$ відступом від іiї зобов’язань за цим міжнародним 
договором, «виключно у тих межах, яких вимагає гострота становища, і за умови, що такі заходи не суперечать іншим iї зобов'язанням згідно 3 міжнародним правом» [1], зокрема тим, що підлягають застосуванню в умовах надзвичайних обставин: Женевські конвенції 1949 р. та Додаткові протоколи до них, Конвенція про статус біженців 1951 р. тощо.

Клаузула про відступ дозволяє державі - учасниці відповідного міжнародного договору зупинити дію / порушувати свої окремі зобов'язання за цим договором в умовах війни або іншої суспільної небезпеки, яка загрожує життю нації. Примітно, що ЄСПЛ вислів «суспільна небезпека, яка загрожує життю нації» в розумінні п. 1 ст. 15 Конвенції 1950 р. тлумачить як «виняткову кризову ситуацію або надзвичайну ситуацію, що впливає на усе населення i становить загрозу для усталеного життя громади, яка формує державу» (пар. 28) [15]. Крім того, ЄСПЛ встановив, що «визначення того, чи загрожує «суспільна небезпека» життю нації і наскільки далеко в такому разі необхідно зайти в намаганні подолати надзвичайну ситуацію, $є$ насамперед обов'язком кожної договірної держави, позаяк вона несе відповідальність за «життя нації»» (пар. 207) [6], за життя своєї нації, а наявність загрози ії життю має оцінюватися, передусім враховуючи факти, умови та обставини, відомі на момент відступу від зобов'язань. Однак ЄСПЛ не позбавлений можливості брати до уваги інформацію, що стає відомою згодом (пар. 177) [6]. «У зв'язку з тим, що національні органи влади безпосередньо та постійно мають справу 3 поточними нагальними потребами, вони загалом мають кращі можливості для вирішення як питання наявності такої надзвичайної ситуації, так і питання про характер і масштаби відступів від зобов'язань, необхідних, щоб їй запобігти. У цьому питанні пункт 1 статті 15 <..> залишає таким органам влади широкі межі оцінки» (пар. 207) [6]. Таким чином, п. 1 ст. 15 Конвенції 1950 р. містить дозвільну норму на вжиття державою заходів, що $\epsilon$ 
відхиленням від її окремих зобов'язань, задля захисту своєї нації від можливих ризиків.

Згідно 3 міжнародними стандартами заходи, що вживаються на відступ, мають бути сумісними 3 іншими міжнародно-правовими зобов'язаннями відповідної держави, що продовжують застосовуватися в умовах надзвичайної ситуації. Таким чином, відступ від зобов'язань, передбачений ст. 15 Конвенції 1950 р. та ст. 4 Пакту 1966 р., не може використовуватися для виправдання порушення інших зобов'язань держави за міжнародним правом. В узагальненому вигляді право держави на дерогацію за Конвенцією 1950 р. передбачає необхідність дотримання вищезазначених умов, покликаних запобігти невиправдано широкому застосуванню такого права [3, с. 271].

Деякі громадянські права людини, гарантовані Конвенцією 1950 р., не допускають відступу від зобов'язань, він вважається неприйнятним, неприпустимим за жодних умов і обставин. Так, п. 2 ст. 15 Конвенції 1950 р. захищає певні права від відступу від зобов'язань щодо їх забезпечення, прямо забороняючи будь-який відступ від: права на життя (ст. 2), крім випадків смерті внаслідок правомірних воєнних дій; заборони катування або нелюдського чи такого, що принижує гідність, поводження або покарання (ст. 3), тобто заборони катування та інших форм жорстокого поводження; заборони рабства і підневільного стану (п. 1 ст. 4); клаузули «ніякого покарання без закону» (лат. «nulla poena sine lege», ст. 7). За аналогією, заборона відступу від деяких прав також стосується положень трьох протоколів, що додаються до Конвенції 1950 р., а саме: Протоколу № 6 (про скасування смертної кари в мирний час і обмеження смертної кари під час війни); Протоколу № 13 (про скасування смертної кари за будь-яких обставин, тобто ї повне скасування); ст. 4 (право не бути притягненим до суду або покараним двічі, лат. ne bis in idem) Протоколу № 7 [див.: 16, с. 1]. За інтерпретацією 
ЄСПЛ, дія п. 2 цієї статті та відповідних положень Протоколів № 6, 7 і 13 про заборону відступу від зобов'язань полягає у тому, що права, на які вони посилаються, продовжують застосовуватися у будь-який час війни або іншої суспільної небезпеки, незалежно від будь-якого відступу від зобов'язань [14, с. 10].

Умову дотримання процедурних вимог закріплено у п. 3 ст. 15 Конвенції 1950 р. Реалізуючи право на відступ від своїх зобов'язань, держава має у повному обсязі поінформувати Генерального секретаря Ради Європи про вжиті нею заходи і докладно обгрунтувати причини їx вжиття, пояснити мету їх запровадження, причини, які зумовили прийняття рішення про відступ. Повідомлення про такі заходи має бути передане без будь-якої затримки, якої можна уникнути, разом 3 достатнім обсягом інформації про них, щоб інші держави-учасниці могли своєчасно оцінити характер і ступінь відступу від зобов'язань, який ці заходи передбачають. Україна 5 червня 2015 р. поінформувала Генерального секретаря Ради Європи про те, що надзвичайна ситуація у Донецькій та Луганській областях змушує органи державної влади вдатися до застосування ст. 15 Конвенції 1950 р. з метою відступу від зобов'язань, взятих за цим міжнародним договором, щодо окремих прав, гарантованих ним [16, с. 2]. Наступні повідомлення України були зареєстровані у Генеральному секретаріаті Ради Європи 4 листопада 2015 р., 30 червня 2016 р., 2 лютого 2017 р. та 3 грудня 2019 р., засвідчуючи повагу до взятих державою міжнародно-правових зобов'язань у сфері прав людини, включно громадянських.

Крім того, держава повинна повідомити Генерального секретаря Ради Європи про час, коли здійснення таких заходів припинено і відновлено дотримання у повному обсязі положень Конвенції 1950 р., відколи вони знову застосовуються в повному обсязі. Завдяки інформуванню Генерального секретаря Ради Європи, з одного боку, відступ від зобов'язань набуває публічності, а з іншого - 
згідно з Резолюцією 56(16) Комітету міністрів будь-яку інформацію, передану Генеральному секретареві на виконання п. 3 ст. 15, він повинен у найкоротший можливий строк повідомити іншим договірним державам. Примітно, що «за відсутності офіційного і публічного повідомлення про відступ від зобов'язань, стаття 15 не застосовується до заходів, вжитих державою-відповідачем» $[14$, c. 11$]$.

Можливість відступу від окремих зобов'язань під час суспільної небезпеки, надзвичайних обставин регламентується дозвільними нормами міжнародного права, які мають тлумачитися обмежувально, це підкріплено міжнародною практикою, включно судовою. Зважаючи на досвід Албанії, Великобританії, Вірменії, Грузії, Греції, Ірландії, Туреччини, Франції [див.: 16, с. 2], які вдавалися до відступу від окремих зобов'язань за Конвенцією 1950 р., та проаналізувавши ситуації, в яких вони реалізовували своє право на вжиття відповідних заходів, що передбачають відступ від окремих договірних зобов'язань, а також дослідивши застосовні загальні принципи запровадження і дії особливого правового режиму надзвичайного стану, можна зробити висновок, що саме на зацікавлену державу покладається обов'язок обгрунтування, передусім керуючись принципом bona fide, необхідності та правомірності відступу нею від окремих зобов'язань у сфері прав людини в обмеженому обсязі та винятково під час виникнення надзвичайних обставин.

\section{3. Міжнародно-правова позиція України щодо відступу від зобов'язань}

В умовах збройного конфлікту і тимчасової окупації частини територій Донецької та Луганської областей Україна була змушена скористатись правом на відступ від виконання окремих договірних зобов'язань у сфері прав людини. Постановою від 21 травня 2015 р. № 462-VIII Верховна Рада України схвалила свою Заяву «Про відступ 
України від окремих зобов'язань, визначених Міжнародним пактом про громадянські і політичні права та Конвенцією про захист прав людини і основоположних свобод» [17], підтверджену Законом України «Про особливості державної політики із забезпечення державного суверенітету України на тимчасово окупованих територіях у Донецькій та Луганській областях» від 18 січня 2018 р. № 2268-VIII у редакції від 2 січня 2020 р. № 113-IX [18]. Йдеться про відступ від окремих зобов'язань, визначених п. 3 ст. 2, статтями 9, 12, 14, 17 Пакту 1966 р. та статтями 5, 6, 8, 13 Конвенції 1950 р., на період до повного припинення збройної агресії Російської Федерації, а саме до моменту виведення усіх незаконних збройних формувань, керованих, контрольованих і фінансованих Російською Федерацією, російських окупаційних військ, їх військової техніки 3 території України, відновлення повного контролю України за її державним кордоном, відновлення конституційного ладу та порядку на окупованій території України (п. 1 Постанови) [17]. Отже, щодо Конвенції 1950 р. Україна заявила про відступ від зобов'язань за окремими 3 прав, а саме: права на свободу та особисту недоторканність (ст. 5); права на справедливий суд (ст. 6); права на повагу до приватного і сімейного життя (ст. 8); права на ефективний засіб правового захисту (ст. 13). Примітно, що заявлений відступ України не стосується решти прав, скажімо, права власності, гарантованого ст. 1 Першого Протоколу до Конвенції 1950 р. Водночас з огляду на значимість і беззаперечність певних основоположних прав, серед яких: право на життя, заборона катувань та нелюдського чи такого, що принижує гідність, поводження і покарання, заборона рабства, як «осердя», «твердого ядра» (англ. "hard core") прав людини, вони гарантуються міжнародними договорами, які не дозволяють дерогації, тобто не допускають відступу держави від виконання зобов'язань щодо цих прав. До таких міжнародних договорів належать: Конвенція про запобігання злочину геноциду та покарання за нього 1948 р., Міжнародна 
конвенція про ліквідацію всіх форм расової дискримінації 1965 р., Конвенція проти катувань та інших жорстоких, нелюдських або таких, що принижують гідність, видів поводження і покарання 1984 р., Європейська конвенція про запобігання катуванням чи нелюдському або такому, що принижує гідність, поводженню або покаранню 1987 р. тощо. Наприклад, право людини на життя, гарантоване ст. 2 Конвенції 1950 р., держави-учасниці зобов’язані забезпечувати і захищати навіть під час війни або іншої суспільної небезпеки, яка загрожує життю нації, позаяк відступ від дотримання такого зобов'язання $\epsilon$ недопустимим згідно 3 п. 2 ст. 15 цього міжнародноправового акту, «крім випадків смерті внаслідок правомірних воєнних дій».

Міжнародно-правова позиція України полягає в тому, що Російська Федерація внаслідок її збройної агресії проти України несе «повну відповідальність за дотримання прав людини і виконання відповідних міжнародних договорів на анексованій та тимчасово окупованій території України», що $\epsilon$ iї невіддільною частиною - Автономна Республіка Крим і місто Севастополь (п. 1 Заяви) [19], а також «як держава, яка фактично окупувала і контролює частину Донецької і Луганської областей, відповідає за дотримання і захист прав людини на цих територіях як за міжнародним гуманітарним правом, так і за міжнародним правом захисту прав людини» (п. 2 Заяви) [19]. Щодо відступу України від окремих зобов'язань за Пактом 1966 р. та Конвенцією 1950 р., то дерогація стосується району проведення 313 квітня 2014 р. широкомасштабної i довготривалої «антитерористичної операції», а з 30 квітня 2018 р. - Операції об’єднаних сил. Згідно з основними принципами і нормами міжнародного права саме Україна $\epsilon$ сувереном цих територій і вони $€$ їі невіддільними складниками. Важливо, що повну відповідальність за дотримання прав людини, виконання договірних зобов'язань і дотримання міжнародних стандартів у цій сфері на тимчасово непідконтрольній частині території 
України несе держава, яка над нею здійснює ефективний контроль. «Триваюча збройна агресія Російської Федерації проти України, яка супроводжується вчиненням воєнних злочинів і злочинів проти людяності як регулярними Збройними Силами Російської Федерації, так i незаконними збройними формуваннями, керованими, контрольованими і фінансованими Російською Федерацією, становить суспільну небезпеку, яка загрожує життю нації» в розумінні п. 1 ст. 4 Пакту 1966 р. та п. 1 ст. 15 Конвенції 1950 р. (п. 3 Заяви) [19]. Донині лише Нікарагуа (1985), Ізраїль (1991) та Азербайджан (1993) посилалися на зовнішню агресію, реалізуючи право на відступ від окремих зобов'язань за Пактом 1966 р. [7, с. 5]. При цьому всі вони офіційно оголосили про існування у державі надзвичайного стану відповідно до положень національного законодавства.

Вживаючи заходів на відступ від окремих зобов'язань, враховуючи можливість свободи розсуду щодо правових засобів реагування з метою запобігання загрозі життю нації, Україна внесла зміни до наявних і прийняла низку законодавчих актів, серед яких: Закон України «Про здійснення правосуддя та кримінального провадження у зв'язку з проведенням антитерористичної операції» від 12 серпня 2014 р. № 1632-VII у редакції від 15 грудня 2017 p. № 2147а-VIII [20], Закон України «Про військовоцивільні адміністрації» від 3 лютого 2015 р. № 141-VIII у редакції від 24 лютого 2018 р. № 2268-VIII [21]. При цьому низка законодавчих актів і Заява Верховної Ради України про відступ України від окремих зобов'язань, Положення про утворення Міжвідомчої комісії з питань відступу України від зобов'язань за Міжнародним пактом про громадянські і політичні права та Конвенцією про захист прав людини і основоположних свобод [22], а також інші нормативно-правові акти потребують оновлення з огляду на припинення широкомасштабної та довготривалої «антитерористичної операції», її заміни на Операцію об’єднаних сил, яка проводиться з 30 квітня 2018 р. Таким 
Права людини в Україні та у зарубіжних країнах:

проблеми теорії та нормативно-правової регламентації

чином, вони почнуть відповідати Закону України «Про особливості державної політики із забезпечення державного суверенітету України на тимчасово окупованих територіях у Донецькій та Луганській областях» від 18 січня 2018 р. № 2268-VIII у редакції від 2 січня 2020 р. № 113-IX [18].

Зрештою, 26 листопада 2019 р. Україна повідомила Генерального секретаря ООН, а він, виконуючи функції депозитарію, усіх інших держав-учасниць [23] про зміни в матеріальній та територіальній сферах застосування відступу від окремих зобов'язань за Пактом 1966 р. (ст. 4) та Конвенцією 1950 p. (ст. 15). Ці зміни безпосередньо пов'язані 3 прийняттям вищеназваного Закону [18] та проведенням Операції об'єднаних сил. Україна припинила відступ від міжнародно-правових зобов'язань за ст. 14 Пакту 1966 р. та ст. 6 Конвенції 1950 р., які гарантують право на справедливий судовий розгляд щодо передання територіальної підсудності судових справ від судів, розташованих на непідконтрольній українській владі частині території України, до судів, розташованих на решті державної території, контрольованої Урядом. Згідно зі ст. 1 Закону України «Про здійснення правосуддя та кримінального провадження у зв'язку з проведенням антитерористичної операції» від 12 серпня 2014 р. № 1632-VII у редакції від 15 грудня 2017 p. № 2147a-VIII [20], зважаючи на неможливість відправлення правосуддя судами в районі проведення Операції об'єднаних сил, розгляд цивільних, адміністративних, господарських і кримінальних справ віднесено до підсудності судів, розташованих на контрольованій Урядом території України. У такий спосіб було змінено норми щодо територіальної підсудності судових справ. Вочевидь Уряд припинив відступ від ст. 14 Пакту 1966 р. та ст. 6 Конвенції 1950 р. на підставі рішень ЄСПЛ, який визнав, що цей захід не порушує права на справедливий судовий розгляд (рішення у справах Khlebik v. Ukraine 
Права людини в Україні та у зарубіжних країнах:

проблеми теорії та нормативно-правової регламентації

(2017) [24]; Tsezar and Others v. Ukraine (2018) [25]), що має фундаментальне значення для демократичного суспільства (пар. 25 рішення у справі Delcourt v. Belgium (1970) [26]).

Уряд України поінформував Генерального секретаря ООН, заявивши також, що заходи, застосовувані у районі проведення «антитерористичної операції», а саме: продовження максимального терміну превентивного затримання підозрюваних у справах, пов'язаних із тероризмом, без перегляду судом з 72 годин до 30 діб і передання певних повноважень слідчих суддів прокурорам - не поширюються на Операцію об'єднаних сил [23], однак формально ці заходи залишаються чинними, законодавчо визначеними. Здійснення наведених Україною у повідомленні заходів може означати відступ нею від зобов'язань відповідно до статей 9, 12, 17 Пакту 1966 р., статей 5, 8 Конвенції 1950 р., ст. 2 Протоколу № 4 до неї та вимагає продовження такої дерогації (п. 2) [23]. Примітно, що наприкінці 2019 р. Україною вперше було змінено матеріальну сферу заявленого відступу від окремих договірних зобов'язань. Визнавши окреслені зміни позитивом, Управління Верховного комісара ООН з прав людини закликало Уряд України регулярно та транспарентно переглядати необхідність і пропорційність відступу від окремих міжнародно-правових зобов'язань, а також якнайшвидше його припинити (п. 71) [27, с. 15]. Міжвідомчою комісією з питань відступу України від зобов'язань за Міжнародним пактом про громадянські i політичні права та Конвенцією про захист прав людини i основоположних свобод рекомендовано «проводити регулярні періодичні перегляди необхідності та пропорційності заходів Уряду з відступу, оприлюднювати результати таких переглядів і припинити вищезгаданий відступ у якомога стислий строк» (п. 133 h) [27, с.31]. В умовах затяжного збройного конфлікту і тимчасової втрати українською владою контролю над частиною 
території України, для забезпечення оптимального застосування будь-яких доступних засобів захисту, передусім держава має подбати про реалізацію юридичних можливостей щодо надання правової оцінки, зокрема, чи здійснює Російська Федерація загальний контроль над відповідною частиною території України, які порушення норм міжнародного права нею вчинено. Водночас важливо визначитись, які засоби захисту, правові інструменти можуть бути застосованими у міжнародних правозахисних механізмах, міжнародних юрисдикційних органах.

У новітній практиці держав спостерігається стала тенденція до зростання кількості відступів ними від своїх окремих міжнародно-правових зобов'язань. Так, у зв'язку з кризою, пов'язаною з COVID-19, Латвія (16 березня 2020 р.), Румунія (17 березня 2020 р.), Республіка Молдова (19 березня 2020 р.), Вірменія (19 березня 2020 р.), Естонія (20 березня 2020 р.), Грузія (23 березня 2020 р.), Албанія (31 березня 2020 р.), Північна Македонія (1 квітня 2020 р.), Сербія (6 квітня 2020 р.) повідомили Генерального секретаря Ради Європи про їхнє рішення скористатись можливістю відступу від зобов'язань під час надзвичайної ситуації, тобто в обставинах, викладених у ст. 15 Конвенції 1950 p. [16, с. 2]. Таким чином, держави все частіше вдаються до дерогації у сфері прав людини, включно громадянських прав, як наслідок, поступово збагачується практика тлумачення і застосування ЄСПЛ відповідних договірних норм. Поза сумнівом, останні слугують одночасно можливостями і викликами для «державних практик» (англ. "governmental practices"), запобігаючи вибірковому, довільному виконанню зобов’язань та їх безкарному порушенню під час надзвичайної суспільної небезпеки.

\section{Висновки}

На території України триває затяжний збройний конфлікт, під час якого грубо і систематично порушуються права 
людини, що актуалізує необхідність розширення можливостей дотримання міжнародних стандартів i розбудови спроможності виконання міжнародних договірних зобов'язань у сфері захисту, inter alia громадянських прав людини, дотримання норм міжнародного права прав людини. Заходи на відступ від зобов'язань, зокрема, спрямовані на те, щоб позбавити суб'єктів права можливості ефективно оскаржувати в суді рішення та/або дії органів держави, їх посадових осіб, що базуються на спеціальному законодавстві. В Україні його ухвалено у зв'язку зі збройним конфліктом і тимчасовою окупацією частини державної території. Однак широкомасштабна та довготривала «антитерористична операція» дотепер потребує заміни на законодавчому рівні на Операцію об’єднаних сил, розпочату в квітні 2018 р., або доповнення належним законодавчим забезпеченням задля збалансування вітчизняного законодавства. Наведене підкреслює значення своєчасних законодавчих змін, забезпечення законодавчої динаміки, позаяк чинна правова база потребує оновлення та удосконалення, узгодження 3 практикою.

Використовуючи право на відступ від зобов'язань в окремих районах Донецької та Луганської областей, Україна не повною мірою дотрималася норм міжнародного права, передусім щодо офіційного оголошення про існування надзвичайного стану як вимоги Пакту 1966 р., негайності та вичерпності повідомлення про відступ, як це вимагається режимом міжнародного повідомлення. Зрештою, оцінку правомірності відступу України від зобов'язань за Пактом 1966 р. може надати Комітет ООН з прав людини як уповноважений орган у системі ООН, а за Конвенцією 1950 р. - ЄСПЛ як конвенційний контрольний механізм. Залишається актуальною потреба періодичного перегляду необхідності збереження заходів, пов'язаних із відступом від «праволюдинних» зобов'язань щодо обмеження матеріальної сфери застосування та територіального охоплення, й така потреба 
зберігатиметься до повного відновлення конституційного ладу та контролю над тимчасово окупованою частиною території України.

\section{Список використаних джерел:}

1. Convention for the Protection of Human Rights and Fundamental Freedoms as amended by Protocols No. 11 and No. 14. Rome, 04.XI.1950. URL: https://rm.coe.int/ 1680063765 .

2. International Covenant on Civil and Political Rights. New York, 19 December 1966. URL: http://www.un.org.ua/ images/International_Covenant_on_Civil_and_Political_Rights_C CPR_eng1.pdf.

3. Денисов В.Н., Фалалєєва Л.Г. Відступ від міжнародноправових зобов'язань у сфері прав людини в умовах збройного конфлікту та тимчасової втрати контролю над частиною території України. Правові питання деокупації та реінтеграції тимчасово окупованих територій України. Бюлетень моніторингу законодавства України. Науковопрактичне видання / заг. ред. О.Л. Копиленка; Інститут законодавства Верховної Ради України. Вип. 8. Київ : Вид-во «Людмила», 2020. С. 260-285.

4. Zand Joseph. Article 15 of the European Convention on Human Rights and the Notion of State of Emergency. Journal of the Faculty of Law of Inonu University. 2014. Vol. 5. No. 1. P. 159-224. URL: https://dergipark.org.tr/tr/download/articlefile/208446.

5. Case of Cyprus v. Turkey (Applications nos. 6780/74 and 6950/75): Report of the European Commission of Human Rights, 10 July 1976. P. 162. URL: file:///D:/Documents\% 20and $\% 20$ Settings/Admin/\%D0\%9C\%D0\%BE\%D0\%B8\%20 \%D0\%B4\%D0\%BE\%D0\%BA\%D1\%83\%D0\%BC\%D0\%B5\%D0 \%BD\%D1\%82\%D1\%8B/Downloads/001142540.pdf\%20(2).pdf.

6. Case of $A$. and Others $v$. the United Kingdom (Application no. 3455/05): Judgment European Court of Human Rights, 
19 February 2009. URL: https://hudoc.echr.coe.int/eng\# \{"itemid":["001-91403"]\}.

7. Аналітична довідка про відступ Уряду України від окремих зобов'язань згідно з міжнародними угодами про права людини, стороною яких $€$ Україна. 20 травня 2016 року. Управління Верховного комісара ООН з прав людини, 2016.12 с.

8. Про правовий режим надзвичайного стану: Закон України від 16 березня 2000 р. № 1550-III у редакції від 28 грудня 2015 р. № 901-VIII. Відомості Верховної Ради України. 2000. № 23. Ст. 176. URL: https://zakon.rada.gov.ua/ laws/show/1550-14.

9. The Siracusa Principles on the Limitation and Derogation Provisions in the International Covenant on Civil and Political Rights. U.N. Doc. E/CN.4/1985/4, Annex (1985): United Nations, Economic and Social Council. $12 \mathrm{p}$. URL: https://undocs.org/pdf?symbol=en/E/CN.4/1985/4.

10. International instruments relating to the promotion of truth, justice, reparation and guarantees of non-recurrence. Office of the United Nations High Commissioner for Human Rights. URL: https://www.ohchr.org/EN/Issues/Truth JusticeReparation/Pages/InternationalInstruments.aspx.

11. Basic Principles and Guidelines on the Right to a Remedy and Reparation for Victims of Gross Violations of International Human Rights Law and Serious Violations of International Humanitarian Law. Adopted and proclaimed by General Assembly resolution 60/147 (A/Res/60/147) of 16 December 2005. URL: https://www.ohchr.org/EN/ ProfessionalInterest/Pages/RemedyAndReparation.aspx.

12. American Convention on Human Rights: "Pact of San José, Costa Rica". 22 November 1969. URL: https://treaties.un.org/doc/Publication/UNTS/Volume\%2011 44/volume-1144-I-17955-English.pdf.

13. Hafner-Burton Emilie M., Helfer Laurence R., Fariss Christopher J. Emergency and Escape: Explaining Derogations from Human Rights Treaties. International Organization. 
2011. Vol. 65(4) 00021. P. 673-707. URL: https://scholarship.law.duke.edu/cgi/viewcontent.cgi?article= 2947\&context=faculty_scholarship.

14. Guide on Article 15 of the European Convention on Human Rights - Derogation in time of emergency. Updated on 31 December 2019. Council of Europe / European Court of Human Rights, 2020. 14 p. URL: https://www.echr.coe.int/ Documents/Guide_Art_15_ENG.pdf.

15. Case of Lawless v. Ireland (No. 3) (Application no. 332/57): Judgment European Court of Human Rights, 1 July 1961. URL: https://hudoc.echr.coe.int/eng\#\{"itemid":["00157518"]\}.

16. Derogation in time of emergency. Factsheet prepared by the ECtHR's Press Unit. April 2020. $16 \mathrm{p}$. URL: https://www.echr.coe.int/Documents/FS_Derogation_ENG.pdf.

17. Про Заяву Верховної Ради України «Про відступ України від окремих зобов'язань, визначених Міжнародним пактом про громадянські і політичні права та Конвенцією про захист прав людини і основоположних свобод»: Постанова Верховної Ради України від 21 травня 2015 р. № 462-VIII. Відомості Верховної Ради України. 2015. № 29. Cт. 267. URL: https://zakon.rada.gov.ua/laws/show/462-19.

18. Про особливості державної політики із забезпечення державного суверенітету України на тимчасово окупованих територіях у Донецькій та Луганській областях: Закон України від 18 січня 2018 р. № 2268-VIII у редакції від 2 січня 2020 p. № 113-IX. Відомості Верховної Ради України. 2018. № 10. Ст. 54. URL: https://zakon.rada.gov.ua/laws/show/2268-19.

19. Заява Верховної Ради України «Про відступ України від окремих зобов'язань, визначених Міжнародним пактом про громадянські і політичні права та Конвенцією про захист прав людини і основоположних свобод». Відомості Верховної Ради України. 2015. № 29. Ст. 267. URL: https://zakon.rada.gov.ua/laws/show/462-19. 
20. Про здійснення правосуддя та кримінального провадження у зв'язку з проведенням антитерористичної операції: Закон України від 12 серпня 2014 № 1632-VII у редакції від 15 грудня 2017 р. № 2147а-VIII. Вiдомості Верховної Ради України. 2014. № 39. Ст. 2009. URL: https://zakon.rada.gov.ua/laws/show/1632-18.

21. Про військово-цивільні адміністрації: Закон України від 3 лютого 2015 № 141-VIII у редакції від 24 лютого 2018 р. № 2268-VIII. Відомості Верховної Ради України. 2015. № 13. Ст. 87. URL: https://zakon.rada.gov.ua/ laws/show/141-19.

22. Положення про Міжвідомчу комісію з питань відступу України від зобов'язань за Міжнародним пактом про громадянські і політичні права та Конвенцією про захист прав людини і основоположних свобод: Постанова Кабінету Міністрів України від 19 квітня 2017 р. № 281. Урядовий кур'єр. 25 квітня 2017. № 77. URL: https://zakon.rada.gov.ua/ laws/show/281-2017-\%D0\%BF.

23. Notification in accordance with the obligations of the Government of Ukraine under Article 4, para. 3, of the International Covenant on Civil and Political Rights. 26 November 2019. URL: https://treaties.un.org/doc/ Publication/CN/2019/CN.618.2019-Eng.pdf.

24. Case of Khlebik v. Ukraine (Application no. 2945/16): Judgment European Court of Human Rights, 25 July 2017. URL: https://hudoc.echr.coe.int/eng\#\{"itemid":["001-175656"]\}.

25. Case of Tsezar and Others v. Ukraine (Applications nos. 73590/14, 73593/14, 73820/14, 4635/15, 5200/15, 5206/15 and 7289/15): Judgment European Court of Human Rights, 13 February 2018. URL: https://hudoc.echr.coe.int/eng\# \{"itemid":["001-180845"]\}.

26. Case of Delcourt v. Belgium (Application no. 2689/65): Judgment European Court of Human Rights, 17 January 1970. URL: https://www.legal-tools.org/doc/5e02c9/pdf/. 
Права людини в Україні та у зарубіжних країнах:

проблеми теорії та нормативно-правової регламентації

27. Report on the human rights situation in Ukraine 16 November 2019 to 15 February 2020. Office of the United Nations High Commissioner for Human Rights, 2020. 46 p. URL: https://www.ohchr.org/Documents/Countries/UA/29thRepor tUkraine_EN.pdf. 
Права людини в Україні та у зарубіжних країнах:

проблеми теорії та нормативно-правової регламентації

DOI https://doi.org/10.36059/978-966-397-210-7/161-184

Заморська Л. I.,

доктор юридичних наук, доцент,

доцент кафедри людських прав

юридичного факультету

Чернівецького національного університету

імені Юрія Федьковича,

м. Чернівці

Гураленко Н. А.,

доктор юридичних наук, доцент,

доцент кафедри людських прав

юридичного факультету

Чернівецького національного університету

імені Юрія Федьковича,

м. Чернівці

\section{ОБМЕЖЕННЯ ПРАВ ЛЮДИНИ І ЙОГО ОСНОВОПОЛОЖНІ ПРИНЦИПИ}

Анотація. У цій науковій роботі була здійснена спроба сформулювати розуміння поняття «обмеження людських прав» як юридичні результати діяльності компетентних державних органів, передбаченої відповідними законодавчими актами, спрямованої на досягнення поставлених цілей задля забезпечення необхідного балансу інтересів окремої людини, держави та суспільства загалом, для охорони благ $i$ цінностей, що передбачені Основним Законом країни.

«Обмеження прав людини» характеризується наявністю відповідних принципів як основоположних засад, на основі яких $i$ формуються певні обмеження. Основне місце серед них належить: законності; легітимності; ясності та визначеності; наявності мети обмеження прав людини, прописаної у Основному законі країни та міжнародно-правових актах; пропориійності; введенню обмежень прав людини, спричиненому винятковими обставинами, на тимчасовий проміжок часу тощо. 


\section{Вступ}

Весь період становлення та розвитку суспільства у взаємодії з правовою державою права та свободи людини і громадянина посідають особливе місце в розвитку будьякої демократичної країни. Забезпечення прав та свобод людини і громадянина, а також їх охорона і реалізація постає надзвичайно актуальною проблемою, особливо в теперішній час, у складних умовах всесвітнього пандемічного періоду, який, як показує практика, здійснив неабиякий вплив на встановлення обмежень прав людини і безпосередньо визначив напрям подальшого впливу на розуміння встановлених меж і заборон.

Наприклад, у ст.2 Конституції України зазначено: «Людина, іiї життя i здоров'я, честь і гідність, недоторканність і безпека визнаються в Україні найвищою соціальною цінністю», i, відповідно, ця норма визначає один із стрижневих напрямів діяльності нашої держави в умовах важкої ситуації, яка складлася в наш час [13]. У країні здійснюється активна діяльність щодо покращення чинного законодавства, вносяться зміни відповідно до міжнародних стандартів, а отже, формується система права, що відповідає демократичному суспільству.

Варто підкреслити, що у законодавстві багатьох Європейських країн, таких як Німеччина, Італія, Іспанія, Франція та інші, цій проблематиці приділяється особлива увага, їх реалізація та захист гарантуються державою шляхом закріплення дієвої системи гарантій (зокрема, як показує практика, в сфері охорони здоров'я). Власне, права і свободи особи проголошуються непорушними [5, с. 118]. Незважаючи на це, ї законодавство передбачає можливість здійснення заходів, що обмежують людські права. Безсумнівно, що в такому разі обмеження має бути передбачене в законодавстві i бути неминучим i вимушеним кроком, без здійснення якого неможливо досягнути поставленої мети, забезпечити громадський порядок, безпеку суспільства тощо в період оголошення 
всесітньої пандемії, що наразі охопила весь світ, та інші охоронювані законом блага.

Протягом значного періоду науковці намагаються віднайти оптимальний баланс між забезпеченням прав та свобод однієї людини та врахуванням інтересів усього суспільства й держави загалом. Одним із проявів втілення цієї ідеї $є$ інститут обмеження прав та свобод людини, який виступає міжгалузевим, охоплюючи норми конституційного, адміністративного, кримінального, цивільного, трудового та інших галузей права, залежно від правової ситуації, яка виникає. Він регулює відносини влади і підпорядкування, а тому для нього характерніший імперативний метод правового регулювання. Обмеження основних прав здійснюється як шляхом прямих заборон, так і вилученням тієї чи іншої правомочності зі змісту конкретного права, а також шляхом встановлення спеціального порядку реалізації такого права тощо.

Зі сказаного вище випливає, що обмеження прав та свобод людини $\epsilon$ необхідним складовим чинником забезпечення оптимального поєднання інтересів людини, суспільства та держави. Ш.Л. Монтеск'є колись зазначив, що «досвід найбільш вільних народів, які коли-небудь існували на землі, змушує визнати, що бувають випадки, коли необхідно на деякий час «накинути на свободу покривало» [17, с.87]. Своєю чергою І.Л. Петрухін наголошував на тому, що потрібно перетерпіти біль державного примусу для того, щоб вилікувати суспільну хворобу [21, с. 221-222].

\section{1. Поняття обмеження прав людини}

Науковці проявляють посилену увагу вивченню проблематики обмеження прав та свобод людини й громадянина. Так, значний внесок в дослідження зазначеної проблематики зробили такі українські та радянські вчені, як Ю.М. Тодика, П. М. Рабінович, О.Г. Кушніренко, Т.М. Слінько, Д.М. Власов, М.З. Ільясов, 
Л.С. Корж, С.В. Пчелинцев та інші. В їхніх наукових працях зазначається ряд обставин, що вимагають поглибленого дослідження, серед них визначення поняття «обмеження прав особи (індивіда)», співвідношення понять «обмеження прав людини» та «порушення прав людини», визначення меж обмежень прав людини та ін.

Аналізуючи погляди М.А. Нагорної, ми дійшли думки, що обмеження прав індивіда застосовується лише у разі, коли виникає необхідність гармонізувати розбіжні інтереси суспільства, держави, особи. При цьому такі обмеження знаходять свій вираз зазвичай у зменшенні обсягу (меж) права за умови збереження його змісту [19, с. 118].

У науковій літературі побутує і така думка, згідно 3 якою обмеження права втілюється не в зменшенні, а у звуженні його обсягу (скороченні числа випадків реальної можливості реалізації права) шляхом розширення змістовної сторони через включення певних факультативних ознак, що регламентують механізм реалізації права. Саме вони можуть стосуватися носія права, порядку реалізації права, кола правомочностей, що складають право, тощо.

М.Ф. Селівон розуміє під обмеженням права не тільки звуження його обсягу, а саме таке звуження, яке здійснюється на законних підставах [34, с. 31]. В.А. Федоров трактує обмеження прав людини : «...вимушене явище, яке спровоковане об'єктивно-суб'єктивними чинниками, зазвичай політико-правової дійсності, що ставить за мету досягнути певних цілей, і здійснюється як правовими, так і неправовими засобами і способами, кількісне та якісне зменшення (російський термін «умаление») органами влади прав і свобод людини» [39, с. 118]. Причому, використовуючи термін «умаление», вчений здійснює підміну понять, фактично ототожнюючи термін «умаление» 3 терміном «порушення», тобто «обмеження прав людини» $\epsilon$ «порушенням прав людини». Ми не цілком погоджуємося з поглядами В.А. Федорова, оскільки ці два поняття $\epsilon$ відмінними між собою. Академічний тлумачний 
словник української мови зазначає [35], що зміст терміну «обмежити» полягає в тому, щоб поставити в певні рамки, межі, визначити якими-небудь умовами, а також зробити менше, скоротити обсяг чого-небудь (в цьому разі зменшити обсяг прав і свобод особи). Термін «порушення» має більш негативну природу і застосовується тільки тоді, коли наявні факти незаконної протидії реалізації прав та свобод людиною [39, с. 27]. Ця особливість чітко і ясно визначає сутність поняття «порушення прав і свобод», а отже, i доводить абсолютну нетотожність понять «обмеження прав і свобод людини» i «порушення прав i свобод людини». Під час дослідження змісту поняття «обмеження» більш доцільним буде застосування понять «звуження», «зменшення» прав людини як синонімічних до російського терміна «умаление». Тобто поняття «обмеження прав людини» включає в себе звуження змісту або обсягу цих прав. При цьому під змістом прийнято розуміти певним чином впорядковану сукупність елементів і процесів, з яких складається предмет чи явище.

Як справедливо зазаначає О.В. Должикова, обмеження прав людини - це спричинена природними, соціальними й духовними чинниками сукупність засобів, що передбачені законодавством і визначають порядок здійснення прав i свобод людини й громадянина у виняткових, надзвичайних обставинах [6, с. 115]. Водночас обмеження слід розглядати через призму поняття «заборона», оскільки обмеження за своєю юридичною суттю дуже схоже 3 забороною, але не тотожне їй. Обмеження спрямоване не на повне «знищення» будь-яких суспільних відносин, а на утримання їх у певних, чітко визначених рамках. Крім того, якщо співставляти терміни «обмеження» та «заборона», то обмеження буде виступати наслідком заборони. Слід не виключати при цьому заперечення можливості існування часткового обмеження, оскільки заборона - це завжди певне обмеження, однак обмеження - це не завжди заборона [38, с. 225-226]. Безперечно, зазначена думка має право на існування, однак потребує додаткового дослідження. 
Права людини в Україні та у зарубіжних країнах:

проблеми теорії та нормативно-правової регламентації

На думку В.А. Карташкіна, обмеження прав і свобод людини державою забезпечує вирішення таких завдань, як: підтримання правопорядку; гарантування безпеки кожної особистості; забезпечення внутрішньої і зовнішньої безпеки суспільства і держави; покращення умов для здійснення економічної діяльності і охорони всіх форм власності; використання мінімальних державних стандартів, враховуючи загальний рівень життя; сприяння розвитку культури в країні $[11$, с. 57].

При цьому О.Ф. Черданцев у своїй праці «Тлумачення права та договору» зазначає, що обмеження слід розуміти як виняткові випадки, коли права та свободи зберігаються, але обмежується можливість їхнього здійснення на певній території, у певний точно визначений часовий проміжок або стосовно певних суб'єктів [40, с. 157]. Ми вважаємо, що наведена думка дуже вдало і найбільш точно передає особливості застосування обмежень прав в умовах виникнення надзвичайних ситуацій.

Досить вдало визначає перелік допустимого обмеження прав людини, що викликаються об'єктивними причинами існування сучасного суспільства I.Ю. Ліщина, вказуючи при цьому на такі: обмеження, які викликані рівнем соціального, економічного, культурного та духовного розвитку соціуму; обмеження, що пов'язуються з певним суб'єктом та його економічними, фізичними та іншими особливостями; обмеження, що виводяться 3 загальновідомої формули «права однієї людини не повинні обмежувати права і свободи іншої людини»; такі, що вводить держава в особі її уповноважених на те органів [15, с. 31].

Своєю чергою ст. 29 Загальної декларації прав людини 1948 р. містить трактування постійних обмежень, необхідних для існування суспільства, передбачивши, що їх може встановлювати лише держава «для забезпечення правомірних вимог моралі, суспільного порядку і загального блага» [9]. У ст. 10 Європейської конвенції про захист прав людини та основоположних свобод 1950 р. міститься схожа підстава, яка передбачає, що обмеження 
можливі лише «для забезпечення державної безпеки та територіальної цілісності» [12].

Слід урахувати і погляди В.А. Номоконова, який тлумачить поняття «обмеження прав людини» двозначно: по-перше, як повне заперечення певного права та (або) свободи, що спровоковане різноманітними об'єктивними та суб'єктивними чинниками; по-друге, як звуження обсягу можливої, дозволеної поведінки (однак, не виходячи за межі конкретного права або свободи) шляхом нормативного визначення компетентними органами певних меж (часових, просторових, суб'єктивних) такої диспозитивної поведінки [20, с. 5]. Проте ми вважаємо, що таке двояке трактування містить у собі порушення логічної послідовності: перша частина поняття повністю включає в себе другу частину, або друга частина поняття повністю підпорядковуєтьчя першій.

Отже, з вищевикладеного випливає, що під час введення обмежень прав і свобод повинні враховуватись такі вимоги: по-перше, обмеження має здійснюватись відповідно до норм права, що закріплені у законах; по-друге, такі обмеження повинні відповідати принципу законності, пропорційності, недискримінації, обгрунтованості, співмірності, доцільності; по-третє, має існувати відповідність обмежень прав людини принципам і нормам міжнародного права.

Варто звернути увагу на те, що існують різноманітні погляди стосовно співвідношення таких понять, як «обмеження прав людини» i «межі здійснення прав людини». Так, німецький науковець К. Хессе підкреслював, що обмеження прав людини $\epsilon$ встановленням меж їх здійснення, трансформацією їх 3 абсолютних у чітко окреслені, оскільки обмеження визначають зміст кожного 3 видів прав індивіда [41, с. 212]. На нашу думку, такий погляд $\epsilon$ доволі дискусійним. Більш об’єктивними $\epsilon$ погляди С.В. Пчелінцева, який у своїх наукових доробках стверджував, що «існує явний взаємний зв'язок між цими поняттями, проте, як цілком влучно підкреслює науковець, 
такі терміни мають різне змістове навантаження та значення» [26, с. 17-18], Б.С. Єбзєєв також вказував на необхідність розмежовувати такі поняття, як «межі здійснення прав та свобод» і «обмеження прав та свобод», вказуючи на те, що за своєю сутністю обмеження прав людини не тотожні встановленням меж прав і свобод [7, с. 117]. Межі реалізації права особи - це зміст і обсяг певного права, система гарантій його реалізації і охорони, наявність яких зумовлена передусім конституційним ладом. Водночас під обмеженнями прав та свобод індивіда слід розуміти «вилучення окремих прав 3 правового статусу людини i громадянина, що допускається Конституцією України та іншими нормативно-правовими актами».

Отже, дискусійним видається розмежування реалізації прав людини і питання про обмеження прав людини $\epsilon$ пов'язаними між собою складовими елементами більш загальної проблеми дотримання оптимального балансу інтересів особи, суспільства та держави.

Дослідження чинного українського законодавства свідчить, що сфера використання поняття «обмеження прав» $\epsilon$ доволі широкою і торкається різноманітних аспектів існування особи, суспільства та держави загалом, особливо в такий важкий час - світової пандемії, яка, безумовно, здійснила свій вплив на сферу застосування заходів обмеження прав людини як в Україні, так і загалом у світі (передусім це стосується сфери обмеження прав на працю та інші). Незважаючи на це, виявляється парадоксальним, що жодний нормативно-правовий акт, який передбачає певні обмеження прав людини, не дає чіткого тлумачення поняття «обмеження» [42, с. 179].

Досліджуючи проблему обмеження прав людини, потрібно відрізняти два поняття: перше - безпосереднє обмеження прав (наприклад, позбавлення особи ії̈ певного права або його частини ), друге - обмеження у реалізації прав (повна або часткова неможливість скористатись певними правами). Другий підхід до трактування 
обмежень передбачає, що усі права у повному обсязі залишаються у людини - носія прав, а лише можливість їхнього здійснення на певний проміжок часу припиняється. Такий вид обмеження може бути добровільним (людина відмовляється від здійснення права, наприклад, у справах приватного обвинувачення) або ж примусовим - застосовується залежно від зовнішніх, здебільшого непередбачуваних, обставин [36, с. 65]. Приміром, це обмеження може бути наслідком введення режиму надзвичайного стану, обставин, що не залежать як від волі окремого індивіда, так і від волі держави. Випадки встановлення такого обмеження повинні бути чітко регламентовані законодавством. На нашу думку, точнішим за змістом $\epsilon$ саме трактування обмежень як обмежень у реалізації суб'єктивних прав, оскільки навіть в умовах воєнного або надзвичайного стану відбувається не тимчасове позбавлення громадян певних прав, а лише тимчасово унеможливлюється їх використання у повному обсязі.

Продовжуючи аналізувати поняття «обмеження прав людини», слід дослідити його найсуттєвіші характерні ознаки: по-перше, обмеження являє собою певні «незручні» наслідки для реалізації певними суб'єктами своїх прав, свобод і законних інтересів, при цьому права i свободи таких фізичних і юридичних осіб обмежуються, однак у той самий час задовольняється суспільний інтерес або інтерес владного суб'єкта, що ввів ці обмеження. Подруге, обмеження за своєю природою - це звуження можливої, дозволеної поведінки (діяльності) [36, с. 67]. Наприклад, Закони України «Про правовий режим території, що зазнала радіоактивного забруднення внаслідок Чорнобильської катастрофи», «Про правовий режим надзвичайного стану», «Про захист населення від інфекційних хвороб» тощо перераховують ті види діяльності, що обмежуються 3 причини виникнення надзвичайних ситуацій техногенного та природного характеру. По-третє, обмеження прав людини, які вводяться за умови виникнення надзвичайних ситуацій, 
завжди мають визначені на законодавчому рівні межі їх реалізації, такі як: просторові - обмеження встановлюються на чітко визначеній території, яка повинна бути зазначена у відповідному прововому акті (постанові Парламенту, указі Президента, розпорядженні Кабінету Міністрів відповідної країни тощо); часові обмеження вводяться за обов'язкової умови встановлення конкретного строку дії таких обмежень, що також зазначається у рішенні суб'єкта влади. Так, Закон України «Про правовий режим надзвичайного стану» чітко окреслює строки дії обмежень, що встановлюються. Вони варіюються залежно від території дії режиму, а саме 30 та 60 днів. Також вищезазначений нормативно-правовий акт гарантує можливість продовжити дію цих обмежень до 30 днів у разі такої необхідності. Тобто загальний строк дії обмежень сягає 90 днів. Однак є певний недолік у змісті цього Закону: стаття 7 не зазначає конткретного числа разів, на який можливо продовжити срок дії режиму надзвичайного стану, а отже, і максимального строку дії обмежень прав людини, які вводяться в процесі запровадження такого режиму [23].

Це питання $є$ гострим нацей час, оскільки фактично українське законодавство передбачає необмежений строк дії обмеження прав людини, які встановлюються за умови введення режиму надзвичайного стану, що може перетворити тимчасові обмеження на повсякденний стан існування суспільства та держави загалом. По-четверте, обмеження прав людини встановлюється лише уповноваженим на це суб'єктом влади, який має відповідні повноваження, прописані в законах чи інших нормативноправових актах, 3 обов'язковим дотриманням процедури введення таких обмежень. По-п'яте, обмеження прав людини, що запроваджуються, зокрема, на підставі виникнення надзвичайної ситуації, тягнуть за собою збільшення повноважень владних органів держави, на яких покладено обов'язок усунути негативні наслідки надзвичайної ситуації. Враховуючи існування балансу, 
варто наголосити, що таке розширення компетенції державних органів відбувається шляхом звуження наявного обсягу прав, свобод та законних інтересів фізичних та юридичних осіб.

Вагомий крок в охороні прав i свобод людини i громадянина від свавільного обмеження зробив Конституційний Суд України, визначивши у Рішенні від 8 квітня 2015 р. «обмеження прав і свобод, передбачених Конституцією, має мати легітимну мету; бути спричиненим суспільною необхідністю досягнення цієї мети, пропорційним та обгрунтованим; у разі обмеження права законодавець зобов'язаний запровадити таке правове регулювання, яке дасть можливість оптимально досягти легітимної мети з мінімальним втручанням у реалізацію відповідного права і не порушувати його сутнісний зміст» [27]. Крім того, важливим кроком в цьому напряму стало прийняття Постанови КМУ № 221 від 11 березня 2020 року «Про запобігання поширенню на територї України коронавірусу COVID-19» [25].

Проведений аналіз найсуттєвіших ознак обмежень прав людини дає можливість дійти висновку, що, незважаючи на політичний режим країни, обмеження - це завжди збільшення компетенції владних суб'єктів, а також - це тимчасове обмеження можливості реалізації особами своїх прав і свобод.

Враховуючи погляди вищезазначених науковців та беручи за основу проаналізовану юридичну літературу, ми можемо доповнити трактування досліджуваного поняття, зазначивши, що обмеження - це юридичні результати діяльності компетентних державних органів, передбаченої відповідними нормативно-правовими актами (законами) та спрямованої на досягнення поставлених цілей, в процесі якої звужуються варіанти диспозитивної поведінки фізичних та юридичних осіб, дозволеної відповідними правовими нормами, шляхом встановлення меж такої поведінки, які вводяться на певний конкретно визначений часовий проміжок або на чітко окресленій території, або 
Права людини в Україні та у зарубіжних країнах:

проблеми теорії та нормативно-правової регламентації

стосовно конкретних суб'єктів, і виражається у встановленні заборон, обо'язків і відповідальності з метою забезпечення необхідного балансу інтересів окремої людини, суспільства і держави загалом, для охорони благ і цінностей, що передбачені Основним Законом країни.

\section{2. Принципи обмеження прав людини}

Обмеження прав людини грунтуються на певних основопложних, фундаментальних засадах - принципах права, які виступають основоположними ідеями, фундаментальними положеннями, які знаходять вираження в нормативно-правовому акті, мають загальну цінність, вищу імперативність і закріплюють в собі суттєві правові положення. Принципи права безпосереднім чином здійснюють вплив на весь процес підготовки законів та інших нормативно-правових актів, їх прийняття, закріплення гарантій дотримання вимог права. Вони $\epsilon$ визначальним критерієм для правотворення, правозастосування та охорони права уповноваженими державними органами. Ступінь дотримання принципів права безпосереднім чином впливає на рівень стабільності та ефективності системи права. Принципи права не виникають самі по собі, вони об'єктивно зумовлені економікою, соціальним буттям, політичним ладом суспільства, що існує в певній державі, соціальною квінтесенцією держави і права, характером існуючого політичного режиму в країні, основними засадами побудови і функціонування політичної системи певного суспільства.

Як справедливо зазначає Л.Д. Воєводін, «правові принципи - це закріплені панівним законом керівні ідеї і установки, які концентровано виражають зміст всієї правотворчої діяльності» [2, с. 115]. Для визнання тих чи інших фндументальних ідей принципами необхідно, щоб вони були закріплені в керівному законі, оскільки ідеї та установки повинні мати вищу правову форму. 
Принципи обмежень прав людини є частиною більш загальної системи правових принципів і являють собою керівні установки, положення, ідеї, зазначені в Основному законі певної держави і які законодавець повинен брати за основу під час нормативного закріплення обмежень тих чи інших прав і свобод людини.

Серед основоположних принципів обмежень прав людини в будь-якій антропоцентричній державі $\epsilon$ принцип верховенства права. Це фундаментальна правова доктрина, яка передбачає, як зазначав відомий український вчений М. Козюбра, що «принцип верховенства права має самостійне значення, яке різниться від традиційної теорії та практики принципу верховенства закону, коли право не $є$ тотожним 3 системою установлених чи санкціонованих державою загальнообов'язкових правил поведінки, іншими словами, коли має місце теоретичне та практичне диференціювання права та закону, тоді як право розглядається як соціальний феномен (коли воно трактується як явище) і безпосередньо пов'язане 3 такими фундаментальними категоріями, як справедливість, свобода, рівність та гуманізм» [14, с. 5]. Окреме дослідження верховенства права як фундаментального правового принципу, в тому числі і основного принципу обмежень прав і свобод людини, було здійснене в монографії С. Головатого «Верховенство права» [3, с. 212], на яку $\epsilon$ посилання в Доповіді Венеційської Комісії «Верховенство права». Отже, випадки та межі обмежень прав людини мають бути чітко закріплені в законах, які своєю чергою $\epsilon$ правовими, тобто відповідають принципу верховенства права, а саме $\epsilon$ зрозумілими, ясними та передбачуваними.

Основоположний принцип верховенства права тісно переплітається 3 принципом правової визначеності, який відіграє важливу роль серед усіх керівних засад обмежень прав і свобод людини. Цей принцип передбачає, що межі, способи, підстави обмежень прав людини мають бути закріплені в нормативно-правових актах, які прийняті у передбаченому законом порядку, доведені до відома 
населення шляхом оприлюднення, чітко закріплюють всі умови обмежень прав і свобод, мають гарантований механізм захисту від внесення непередбачуваних змін тощо.

В Україні врегулювання проблеми обмеження прав та свобод людини опирається на принцип недопущення будьякого обмеження прав та свобод. Зсилаючись на положення, закріплені у ст. 64 Конституції України [13], можна визначити, що права та свободи людини i громадянина, закріплені в Конституції, не можуть обмежуватись, за вийнятками, які передбачаються в Законі, а у разі прийняття нових нормативно-правових актів чи внесенні змін до діючих забороняється звужувати зміст та обсяг вже наявних прав та свобод.

Для недопущення неправового обмеження прав та свобод людини були встановлені конституційні гарантії, які знайшли своє вираження у ст. 57 Конституції України [13], в якій передбачається, що нормативно-правові акти, які закріплюють права та обов'язки громадян, у разі якщо про них не було доведено до населення шляхом, який визначається законом, $\epsilon$ недіючими. Крім того, закріплюється положення, що права та свободи людини i громадянина, гарантії їх здійснення, а також обов'язки закріплюються винятково у законах України (ст. 92) [13], та будь-які зміни до Конституції України, у разі якщо вони передбачають обмеження або скасування прав та свобод людини й громадянина, забороняються (ст. 157) [13].

Як зазначає 0.0. Подмарев [22, с. 63], до принципів обмеження прав і свобод людини і громадянина слід віднести:

1) визнання людини, їі прав і свобод, гідності і честі найвищою соціальною цінністю в державі. Досліджуючи сутність цього принципу, можна дійти висновку, що, базуючись на положеннях Основного Закону України, його складовими елементами $\epsilon$ : життя і здоров'я, честь i гідність, недоторканність і безпека особи. Закріплення вищеперерахованих благ попарно зумовлено високим 
ступенем їх взаємозв'язку та невіддільності одне від одного;

2) відповідність обмежень прав людини цілям, які закріплені в панівному законі. Також поширеною практикою $\epsilon$ закріплення у статтях, що передбачають окремі права та свободи, додаткових умов обмеження реалізації цих прав та свобод;

3) рівність в обмеженнях прав i свобод. Принцип рівності правового статусу особи передбачає, що кожній людині гарантується однакова сукупність прав, свобод та обов'язків, визначається для всіх однакова міра юридичної відповідальності за однакові протиправні діяння. Згідно з цим принципом обмеження прав і свобод здійснюються на основі рівного правового положення всіх осіб i дискримінувати одного індивіда, покладачаючи на нього більший тягар обмежень прав і свобод, ніж на іншого, який перебуває в тому самому положенні, забороняється;

4) заборону обмежувати права і свободи людини за ознаками соціальної, расової, національної, мовної, етнічної чи релігійної приналежності. Принцип недискримінації передбачає відсутність неправомірного відмінного відношення (в цьому разі встановлення обмежень прав людини) до осіб, які перебувають в однакових умовах чи однакового ставлення до осіб, які знаходяться в різних умовах. Оскільки дискримінація унеможливлює реалізацію прав і свобод усіма людьми на рівних підставах, то їі заборона розглядається як один із способів дотримання рівності всіх осіб. Право на захист від дискримінації $є$ одним із найсуттєвіших прав людини, важливість якого визнана міжнародною спільнотою, воно має бути забезпечене сучасними країнами;

5) встановлення правової форми нормативного закріплення обмежень прав людини. Базуючись зазвичай на позитивістському розумінні права, обмеження прав людини можуть бути встановлені: конституцією (наприклад, у Вірменії, Білорусі, Бельгії, Боснії і Герцоговині, Туреччині, Україні, Хорватії, Естонії тощо); 
законом (зокрема, в країнах Австрії, Андоррі, Болгарії, Литві, Польщі тощо) [16, с. 118]; міжнародними законодавчими актами (у Люксембурзі людські права можуть бути обмежені лише у разі наявності умов у «Європейській Конвенції про захист прав та основоположних свобод» від 1950 р.);

6) дотримання міжнародних стандартів під час встановлення обмежень прав та свобод людини. Такі документи, як «Загальна декларація прав людини» (1948р.), «Міжнародний пакт про громадянські та політичні права» (1966 р.), «Міжнародний пакт про економічні, соціальні й культурні права» (1966 р.) та інші зосереджують увагу на тому, що особа не може бути обмежена у реалізації своїх прав та свобод. Проте, як зазначається у вже наявних міжнародних угодах, «існують чітко визначені випадки надзвичайного чи нетипового характеру, за настання яких з обов'язковим встановленням конкретних часових і просторових меж запроваджуюються обмеження прав людини» [1, с. 18]. Цілі цих можливих відступів від наявних прав і свобод захищаються міжнародними угодами. 3 одного боку, це дає можливість державі, керуючись відповідними міжнародно-правовими актами, вводити вимушені обмеження на реалізацію певних прав, а з іншого - гарантує захист громадян від свавілля держави в обмеженні їх прав.

В.В. Назаров до принципів обмежень основних прав i свобод відносить такі:

1) законність. Обмеження прав і свобод людини здійснюється згідно з законом. При цьому в законі повинні бути чітко прописані способи та механізм обмеження прав людини;

2) легітимність. Єдиною основою обмеження прав людини є визнання його суспільної необхідності, коли інші наявні засоби державного впливу $є$ недієвими, за умови існування гострої потреби встановлення меж реалізацї суб'єктивного права для захисту інтересів інших осіб, суспільства загалом; 
3) ясність, чіткість і визначеність. Закріплений у законі процесуальний порядок обмеження прав людини повинний бути прописаний таким чином, щоб він був зрозумілий як посадовій особі, так і пересічному громадянину;

4) наявність цілі обмеження прав людини, прописаної у панівному законі країни та (або) міжнародно-правових актах;

5) пропорційність. Обмеження не може бути більш жорстким, ніж цього вимагає суспільна необхідність; має бути забезпечений баланс між правами людини, гарантованими Конституцією України, і інтересами суспільства;

6) введення обмежень прав людини, що спричинене винятковими обставинами, на тимчасовий проміжок часу [18, с. 413-414].

Загальноприйнятою $\epsilon$ вимога про те, що заходи обмежувального характеру не мають бути надмірними і повинні бути відповідними обставинам, які спричинили їхнє виникнення, і в цьому разі принцип пропорційності обмеження прав і свобод $є$ одним із найсуттєвіших.

Як вважає В.Б. Рушайло, принцип пропорційності знаходить своє вираження таким чином: відповідність міри і обсягу обмежень прав і свобод людини ситуації надзвичайного або нетипового характеру; встановлення обмежень прав і свобод людини як вимушеного заходу тільки в тому разі, коли вичерпані усі заходи державного примусу, що застосовуються за звичайних обставин; визначення як мети встановлення обмежень прав і свобод людини стабілізацію або ліквідацію конкретної екстремальної ситуації.

До принципу пропорційності входять чотири основні вимоги, пов'язані головним чином 3 цілями обмежень: обгрунтування обмежень; важливість цілей обмеження; відповідність ступеня обмеження прав суспільній значимості цілей обмеження або значущості охоронюваних 
прав; необхідність застосування принципу пропорційності одночасно 3 принципами недискримінації, рівності, законності, справедливості [33, с. 217].

Аналізуючи Європейську конвенцію про захист прав та основоположних свобод 1950 р. та практику Європейського суду 3 прав людини, науковець В.А. Туманов [37, с. 34] виділяє основні принципи (критерії) правомірного обмеження прав людини:

1) обмеження прав i свобод людини мають бути передбачені законом. При цьому Європейський суд з прав людини розуміє закон в сенсі, що включає в себе будь-який нормативний акт державного органу (наприклад, «Справа Санді Таймс» проти Сполученого Королівства Великобританії (1979 р. [28]);

2) законність мети. Держава може здійснювати обмежувальні заходи задля цілей, зазначених у Конвенції (наприклад, «Справи Хендісайд проти Сполученого Королівства Великобританії» (1976 р.) [29], «Даджен проти Сполученого Королівства Великобританії» (1984р.) [30], «Мюллер та інші проти Швейцарії» (1988 р.) [31];

3) необхідність встановлення таких обмежень. Очевидна невизначеність цього критерію зумовила активну діяльність Суду з тлумачення вказаних термінів. У судових рішеннях по «Справах Хендісайд проти Сполученого Королівства Великобританії» (1976 р.), «Сілвер та інші проти Сполученого Королівства Великобританії» (1983р.) [32] було надане таке визначення «необхідності»: «воно не $\epsilon$ синонімом прикметника «необхідний»» і не має тієї гнучкості, які мають такі терміни, як «допустимий, звичайний, корисний, розумний або бажаний».

Ще в римському праві були закріплені обмеження реалізації права власності на земельні ділянки. Так, у Дігестах Юстиніана право власності на публічні дороги обмежувалося правом всіх громадян пересуватися ними, переміщувати вантажі та переганяти худобу. Власники приватних доріг також у певних випадках були зобов'язані надавати їх «для всіх і кожного» [4, с. 93]. 
Згідно 3 українським законодавством обмеженням права на землю слід вважати закріплену в законі заборону або додатковий обов'язок щодо вчинення дій, пов'язаних 3 набуттям, використанням та відчуженням земельних ділянок. Прикладом встановленого законом обмеження прав на землю $\epsilon$ заборона набуття іноземцями у власність земельних ділянок сільськогосподарського призначення. Крім цього, обмеження прав власників землі може передбачатись договором та судовим рішенням у рамках закону [10].

Дослідивши трактування поняття «обмеження прав людини» в науковій літературі, можна узагальнити такі принципи i положення, якими мають керуватись уповноважені органи під час здійснення правообмежуючих заходів: 1) справедливе співвідношення інтересів однієї людини 3 інтересами групи людей, суспільства; 2) існування балансу приватних та публічних інтересів. Необхідність поєднання приватного і публічного інтересів спонукає до обов'язкового встановлення оптимальних меж або кордонів, дотримання пріоритету принципу справедливості і недопустимості протиставлення публічних і приватних інтересів один одному. Надання переваги одному інтересу і прояв зневаги до іншого не дозволяється, оскільки публічне право ставить за мету захищати інтереси окремої людини шляхом охорони суспільства загалом. Під час зіставлення публічного і приватного інтересу реалізація інтересів суспільства може існувати лише на підставі реалізації інтересів індивіда, що забезпечується створенням на законодавчому рівні максимальних гарантій для громадян, які не допускають можливість зловживання правами людини.

Отже, проаналізувавши проблему співвідношення публічного і приватного інтересів, можна дійти висновку, що інтереси мають реалізовуватись на засадах паритету, рівноцінності, оскільки приватний інтерес не може бути забезпечений у разі порушення публічного правопорядку, а публічний інтерес втрачає своє призначення, якщо він не націлений на забезпечення реалізації приватного. 3 цього 
своєю чергою випливає, що приватне і публічне право, кожне 3 яких захищає відповідні інтереси, $€$ тісно взаємопов'язаними і невіддільними складовими частинами єдиної інтегрованої системи права; відповідність заходів, здійснених для обмеження прав людини, правомірній i нагальній меті; пріорітет обмежень прав людини, встановлених міжнародними нормативно-правовими актами, щодо обмежень, передбачених національним законодавством; неприйнятність встановлення у законах таких меж прав людини, які є вужчими, ніж ті межі, які закріплені в панівному законі держави; відсутність дискримінації (забезпечення формальної рівності) індивідів в їхніх правах і обмеженнях цих прав; законність та аргументованість необхідності обмежень прав людини.

\section{Висновки}

Таким чином, принципи обмеження прав людини - це фундаментальні, керівні положення та установки, які законодавець повинен використовувати як орієнтир під час нормативного закріплення обмежень тих чи інших прав i свобод людини. Закріплення принципів правообмеження має не тільки велике теоретичне, але й практичне значення. Оскільки вищезазначені фундаментальні положення виступають критерієм правомірності обмеження прав людини у правотворенні та правозастосуванні. Нехтування вказаними принципами призводить і до порушення передбачених законом меж здійснення прав людини.

\section{Список використаних джерел:}

1. Алексеева Л.Л., Андриченко Л.В., Боголюбов С.А., Домрин А.Н., Касаткина Н.М. Конституционное право государств Европы : Учеб. пособие для студ. юрид. вузов и $\phi$-тов / Институт законодательства и сравнительного правоведения при Правительстве Российской Федерации Москва : Волтерс Клувер, 2005. 310 с. 
2. Воеводин Л.Д. Юридический статус личности в России. Москва, 1997. 299 с.

3. Головатий С. Верховенство права. Київ : Видавництво «Фенікс», 2006, 1747 с.

4. Гринько С.Д. Дигести Юстиніана як джерело римського приватного права. Університетські наукові записки. 2007. № 1. С. 90-96.

5. Донеллі, Дж. Людські права у міжнародній політиці [Текст] : наук. вид. / пер. 3 англ. Т. Завалія. Львів : Кальварія, 2004. 280 с.

6. Должиков A.В. Конституционные критерии допустимости ограничения основных прав человека и гражданина в Российской Федерации. Тюмень, 2003. 242 с.

7. Эбзеев Б.С. Человек, народ, государство в конституционном строе Российской Федерации. Москва, 2005. $326 \mathrm{c}$.

8. Загальна декларація прав людини: ООН; Декларація, Міжнародний документ від 10.12.1948. URL: http://zakon4.rada.gov.ua/laws/show/995_015.

9. Загальна теорія держави і права (основні поняття, категорії, прав. конструкції та наук. концепції) Київ : Юрінком Інтер, 2008. 400 с.

10. Земельний Кодекс України. Редакція від 28.09.2017. URL: http://zakon3.rada.gov.ua/laws/show/2768-14.

11. Карташкин В.А. Права человека в международном праве и внутригосударственном праве. Москва : Изд-во ИГиПРАН, 1995.133 с.

12. Конвенція про захист прав людини i основоположних свобод. Ратифіковано Законом № 475/97-ВР від 17.07.97\}. URL: http://zakon0.rada.gov.ua/ laws/show/995_004.

13. Конституція України від 28 червня 1996 р (зі змінами та доповненнями станом на 20.04.2020). URL: http://zakon2.rada.gov.ua/laws/show254к/96-вр.

14. Козюбра М.І. Право і людина: лінії взаємозв'язків та тенденції розвитку.Наукові записки НаУКМА. Юридичні 
науки. 2015. T. 168. C. 3-9. URL: http://nbuv.gov.ua/UJRN/ NaUKMAun_2015_168_3.

15. Ліщина I. Регулювання реалізації рішень Європейського Суду з прав людини. Право України. 2001. № 5. C. $29-37$

16. Маклаков В.В. Современные зарубежные конституции. Москва : МЮИ, 1992. 290 с.

17. Мироненко О.М. Монтеск'є Шарль Луї. Політична енциклопедія. Редкол.: Ю. Левенець (голова), Ю. Шаповал (заст. голови) та ін. Київ : Парламентське видавництво, 2011. 465 c.

18. Назаров В.В. Обеспечение права на свободу и личную неприкосновенность в уголовном производстве. Актуальные проблемы уголовногоправа, процесса $u$ криминалистики : материалы IV междунар. наук-практ. конф., присвяч. 95-летию со дня рождения профессора М В. Салтевського (м. Одесса, 2 нояб. 2012 г.). Одесса : Феникс 2012. С. 413-417.

19. Нагорная М.A. Принципы ограничений прав человека в публичном праве. Теория и практика ограничения прав человека по российскому законодательству и международному праву : сб. науч. тр. Н. Новгород, 1998. С. 57-69.

20. Номоконов В.А. Права человека и национальная безопасность / В. А. Номоконов. Криминологический журнал Байкальского государственного университета экономики и права. Иркутск : Изд-во БГУЭП, 2008. № 2. С. 5-6.

21. Петрухин И.Л. Теоретические основы эффективности правосудия. Москва, 1979. 392 с.

22. Подмарев А.А. Ограничение прав и свобод человека и гражданина: конституционные основы и правовые позиции Конституционного Суда России. Вестник СанктПетербургского университета МВД России. 2016. № 4. C. 62-66.

23. Про правовий режим надзвичайного стану. Закон України. Редакція від 28.12.2015. URL: http://zakon3.rada.gov.ua/laws/main/1550-14. 
24. Про введення надзвичайного стану в населених пунктах Автономної Республіки Крим. Закон України. Редакція від 30.12.2005. URL: http://zakon2.rada.gov.ua/ laws/show/1692/2005.

25. Про запобігання поширенню на території України коронавірусу COVID-19. Постанова КМУ № 221 від 11 березня 2020 року. URL: https://www.kmu.gov.ua/npas/ pro-zapobigannya-poshim110320rennyu-na-teritoriyiukrayini-koronavirusu-covid-19.

26. Пчелинцев С.В. Проблемы ограничения прав и свобод граждан в условиях особых правовых режимов. Москва : НОРМА, 2006. 480 с.

27. Рішення Конституційного Суду України у справі за конституційним поданням Уповноваженого Верховної Ради України з прав людини щодо відповідності Конституції України (конституційності) положень частини другої статті 1712 Кодексу адміністративного судочинства України від 8 квітня 2015 року № 3-рп/2015. URL: http://zakon4.rada.gov.ua/laws/show/v003p710-15).

28. Рішення Європейського суду по справі «Санді Таймс» (Sunday Times) проти Об'єднаного Королівства (стаття 50)». URL: http://zakon2.rada.gov.ua/laws/show/ 980_164

29. Рішення Європейського суду по справі «Хендісайд проти Сполученого Королівства». URL: http://www.echr.coe.int/echr.

30. Рішення Європейського суду по справі «Даджен проти Сполученого королівства Великобританії та Північної Ірландії». URL: http://www.echr.coe.int/echr.

31. Рішення Європейського суду по справі «Мюллер та інші проти Швейцарії». URL: http://www.echr.coe.int/echr.

32. Рішення Європейського суду по справі «Сільвер проти Сполученого Королівства». URL: http://www.echr.coe.int/echr.

33. Рушайло В.Б. Специальные административноправовые режимы в Российской Федерации. Москва, EKCMO, 2004. $347 \mathrm{c}$. 
34. Селивон Н. Критерии ограничения прав человека в практике конституционного правосудия. Конституционное правосудие. Вестник Конференции органов конституционного контроля стран молодой демократии. 2005. Вып. 3 (29). С. 28-37.

35. Словник української мови. Академічний тлумачний словник. URL: http://sum.in.ua/s/kryterij.

36. Стефанчук М.0. Межі здійснення суб'єктивних цивільних прав. Київ, 2006. 176 с.

37. Туманов В.А. Европейский суд по правам человека. Москва, 2001. 149 с.

38. Фаткуллин Ф.Н. Проблемы теории государства и права : курс лекцій. Казань : Изд-во Казанского гос. ун-та, 1987. $336 \mathrm{c}$.

39. Федоров В.А. Правовой институт исключительного (военного и чрезвычайного) положения в Российской Федерации. Москва, 2003. 231 с.

40. Черданцев А.Ф. Толкование права и договора. Москва : ЮНИТИ, 2003. 381 с.

41. Хессе К. Основы конституционного права ФРГ. Москва, 1981. 332 с.

42. Шишкін B.I. До питання гармонізації законодавства України 3 європейським правом щодо захисту прав людини. Матер. наук.-практ. конфер. [«Проблеми гармонізації законодавства України 3 міжнародним правом»]. Київ : Інститут законодавства Верховної Ради України, 1998. С. 178-182. 
Права людини в Україні та у зарубіжних країнах:

проблеми теорії та нормативно-правової регламентації

DOI https://doi.org/10.36059/978-966-397-210-7/185-207

Заяць Н. B.,

доктор юридичних наук, доцент, професор кафедри конституційного

та адміністративного права

Державного університету інфраструктури та технологій, м. Київ

\section{ГІДНІСТЬ ЛЮДИНИ ЯК АБСОЛЮТНА ЦІННІСТЬ: ФІЛОСОФСЬКО-ПРАВОВЕ РОЗУМІННЯ}

Анотація. Людська гідність як окрема категорія набула широкого поширення в національних конституціях після Другої світової війни як реакція на «злочини проти людства», ставши джерелом всіх інших прав та свобод. Узапропонованій праці розкривається багатоаспектність сутності категорії «гідність», яка може розкриватись у діапазоні від позначення мінової вартості, що належить суб'єкту, до статусу та суспільної значимості особистості, яка виступає результатом суспільної діяльності та вчинків окремого індивіда, крім цього, часто термін «гідність» використовують для позначення морального ставлення та світовідчуття людини у процесі самовизначення в світі інших. Окремо також вказується на різноманіття у розумінні та обгрунтуванні цього явища через площину філософії, моралі, медицини та права залежно від функціонального навантаження. Аналізуючи гідність людини у філософському аспекті, нам вдалося виявити їі антропологічні властивості як вродженої та абсолютної цінності, які під час подальшого аналізу сприяли розумінню цієї категорії у медичній та правовій сферах через взаємозв'язок із системою прав і свобод людини. Зазначена проблема ускладнюється тим, що украӥнська юридична наука ще й досі недостатньо опанувала філософію людської гідності. Окремо розглянуто концепт розуміння людської гідності в українському конституційному регулюванні, відповідно до якого пріоритетом охорони права 
визнано саме життя людини, а не те, що, власне, робить їі людиною, зокрема ї̈ гідність, яка вважається моральноетичною категорією.

Усталене тепер у вжитку поняття «людська гідність» $\epsilon$ найбільш стислою лінгвістичною формою вираження суті ідеї про природне право. Відповідно, категорія «гідність» виходить за межі суто юридичної теми, маючи глибокі корені у теологічних вченнях багатьох релігій, у моралі, у політичній філософії, в антропології, в медицині тощо.

\section{Вступ}

Як у політичній, так і філософській літературі концепції людських прав та людської гідності розглядаються як переплетені між собою: боротьба в ім'я людської гідності мала вплив на еволюцію дискурсу про людські права, а дискурс про людські права своєю чергою став головним знаряддям для вираження та цінування гідності людини.

У європейській світоглядній філософській думці категорія «гідність» людини як неправова гуманістична цінність зародилася ще в античний час. Саме тоді етика розглядала цю категорію в двох аспектах: по-перше, через призму людської самооцінки, особливого морального ставлення людини до самої себе; по-друге, через визначення соціальної значимості особистості, ставлення до неї з боку суспільства, що визнає ії соціальну цінність. Ми здійснюємо вплив на людську гідність тим, що ми робимо, а не тим, що ми відчуваємо, оскільки ми відповідальні саме за те, що ми робимо, а не за те, що інші роблять 3 нами. Наші дії, так само як і наша бездіяльність, залежать від кожного з нас, а тому будь-яка діяльність щодо людської гідності в наших відносинах 3 іншими людьми $є$ проблемою етичних стосунків кожного з нас із самим собою, незважаючи на те, що наша діяльність спрямована на когось іншого. Індивідуальне етичне самовизначення наповнене цілим спектром етичних відтінків гідного та негідного, честі та безчестя, які у 
випадках межових ситуацій, що перевершують інстинкт самозбереження, набувають засадничого значення [1].

Підкреслюючи засадниче значення межових ситуацій для актуалізації питання людської гідності, необхідно звернути увагу, що це питання вже неодноразово порушувалось як в історико-філософському, так і у політикоправовому дискурсі. Очевидно, що сьогодні Україні потрібно оновити методологічний інструментарій досліджень питань поваги i захисту гідності людини: крім філософії юридичного та соціологічного позитивізму, слід, зокрема, розвивати й філософію природного права, яку вченіпозитивісти, яких більшість в Україні, сприймають досить критично. Адже саме ця філософія є живильним середовищем для формування суспільної ідеології та природного права на повагу i захист гідності людини, як i багатьох інших прогресивних починань (в освіті, культурі тощо).

У цьому контексті доречно згадати філософську спадщину Платона, Аристотеля, I. Канта, Г. Гегеля, Дж. Локка, а також вітчизняних та зарубіжних вчених та фахівців, які зробили вагомий внесок у наукову розробку цього питання, спробувавши розкрити поняття людської гідності, як моральної ідеї (О. Барак, Р. Говард, В. Бачинін), правової цінності (Дж. Валдрон, Ю. Габермас, С. Головатий, П. Рабінович, П. Хеберлє), право людини (А. Кампо, Р. Арнольд, С. Вдовиченко, В. Головченко, М. Гультай, М. Савчин), джерело прав людини (О. Грищук, Н. Колесова) та інші. Наведений поділ $є$ досить умовним, адже більшість авторів підтримують подвійну природу людської гідності: як явища об'єктивного (цінність, принцип, джерело прав людини, їх мета чи зміст) та як суб’єктивного права чи інтересу конкретної людини, вживаючи декілька понять одночасно.

\section{1. Філософський вимір людської гідності}

Варто відзначити, що класична антична філософія змістовно визначила розуміння людської гідності, 
встановивши тісний зв'язок між поняттями гідність та особистість. Зокрема, римському праву були притаманні такі поняття, як індивідуальна та групова честь, що $\epsilon$ складниками поняття гідності. Для Стародавнього Риму гідність людини - це їі основний екзистенційний вимір, який володіє найвищою цінністю. Ніхто не може порушити гідність людини, забравши від неї важливі блага, і навіть ув'язнення не $\epsilon$ порушенням ії гідності [2]. Проте тоді ще не йшлося про недоторканість гідності окремої особистості, ні давньогрецька, ні давньоримська суспільно-політична думка не розуміли самоцінності людського індивіда. Ідея індивідуалізації сформувалась лише в сучасному суспільстві, що сприяло утвердженню абсолютної цінності особистості та її моральної гідності. Варто зазначити, що ідея гідності у давньогрецькому світогляді часто набувала етико-антропологічного характеру. Це було зумовлено тим, що давньогрецькі мислителі досліджували проблему гідності в контексті пошуку людиною своєї «чесноти», яка забезпечувала здатність виконувати власне призначення. Саме «призначення» кожної речі або істоти було пов'язане 3 наявністю у них «гідностей», які зазвичай тлумачили як ціль, відповідність чи придатність. Показовим був той факт, що таке призначення, а відтак і гідність людини, на думку давній греків, визначали здатністю підпорядковуватись природним i соціальним законам. Гідність людини, на думку Платона, пов'язана з красою безсмертної душі людини, 3 такими ідеями, як справедливість та вихованість. Акцентуючи увагу на суб'єктивній визначеності гідності людини, Платон визначає: «гідною людиною $є$ та, яка має гідну душу. Мерзенна людина ж має душу негідну» [3]. Праця Аристотеля «Нікомахова етика» і сьогодні залишається актуальною щодо розуміння гідності людини. Він визнавав за можливе виховати якості гідної людини через освіту як процес передачі істинних цінностей. Таким чином, гідність людини більшою мірою залежить від моральних принципів, обраних нами усвідомлено, які знаходять своє місце у відповідних 
вчинках. Своєю чергою моральність вчинків є головним принципом життя людини [4]. За Аристотелем, гідність людини визначають іï душевні, розумові здатності, правильні вчинки, а також істинна цінність людини, що співвіднесена з її соціальною значущістю.

Проблематика людської гідності як самостійний предмет дослідження виникла в європейській гуманістичній філософії в XIII-XVI століттях та набула особливої актуальності у філософії доби Ренесансу та Нового часу. Поступово у філософсько-правових поглядах XIX століття утверджується ідея абсолютної людської цінності, що знайшло своє втілення в концепції I. Канта «Основа метафізики моральності», який розробив власне бачення гідності, засноване на «вищому принципі моральності», за яким людська гідність незаперечна. Це та річ, яку не можна придбати чи продати і яка не має відносну цінність. Те, що вище за всяку ціну, є умовою самої себе і самоціллю та виявляє внутрішню цінність - це гідність [5]. Формулювання I. Канта дозволяє побачити «цінність такого способу думки, як гідність, і поставити її вище за всяку ціну, яку з нею не можна порівняти, не зазіхаючи при цьому на святість гідності». По суті, І. Кант визначає спільні межі однієї з версій визначення категоричного імперативу, яке за сутністю визначено у такому твердженні: «Вчиняй так, щоб ти завжди ставився до людства і в своїй особі, і в особі будь-кого іншого так само, як до мети, і ніколи не ставився б до нього так само, як до засобу» [6]. На думку I. Канта, основою гідності людини $\epsilon$ свобода як автономія особистості. Він стверджує, що автономія - $\epsilon$ основою гідності людини і будь-якої іншої розумної істоти. Це було пов'язано насамперед 3 опором людей приниженню та насиллю з боку абсолютиської держави. Вся природноправова філософія зводила юридичну формулу людської гідності до універсальних етичних максимумів і релігійних абсолютів. На почутті власної гідності мала вибудовуватись самосвідомість особистості як громадянина, готового обстоювати свої права і свободи; це ж почуття не 
повинно було дозволити йому порушувати моральноправові норми [7, с. 108]. Таким чином, у практичній філософії І. Канта гідність людини - це внутрішній моральний закон, який обмежує та (або) знецінює природні та соціокультурні чинники, відкриваючи можливість для реалізації автономії людської особистості.

Філософське доктринальне бачення людської гідності як права людини набуло засадничого бачення як індивідуальної цінності 3 часів нищівного руйнування гуманітарних та правових порядків протягом Другої світової війни, коли недооцінка природного правового компонента конституційного регулювання, зокрема питань поваги та захисту гідності людини, негативно позначилася на стані їх дотримання в Європі. Хоча поствоєнні рухи за права людини дійсно сприяли покращенню соціального, економічного, політичного статусу пригноблених верств населення, проте вони змінили тон політичних, судових та філософських дебатів 3 центрального питання про зміст людської гідності, навіть не намагаючись відповісти на це питання, через що багато людських прав залишились невизнаними [8, с. 2]. Від часу своєї появи у найпершому міжнародному акті поняття «людська гідність» стало центровим стосовно людських прав, i протягом останнього часу основні конфесії, суверенні країни й міжнародні організації декларативно визнали гідність людини фундаментальною моральною та правовою цінністю, а термін «гідність» 3'явився в сучасних національних конституціях 157 країн [9, с. 2] Людська гідність як цінність чи принцип розглядається часто у християнській етиці і через європейську традицію права вона знайшла своє закріплення у міжнародному праві. Найважливіше офіційне визнання це отримало у Преамбулі Статуту ООН (1945) як «гідність людини» та Преамбулі Загальної декларації прав людини (1948), як «внутрішньо притаманна гідність усіх членів людської родини», що несе навантаження першоджерела, яким виступає теологічне світобачення, 3 якого походить ідея людської 
рівноправності. Саме в Декларації ООН вперше було визначено спадкову лінію ідеї невіддільних (природних) прав: вона проклала місток між філософією вступної частини Декларації незалежності США 1776 року та майбутнім новим світовим порядком на основі Статуту ООН, де держави-засновниці виразили свою мету «наново підтвердити віру в основоположні людські права, у гідність та цінність людини» «визнання гідності, властивої всім членам людської сім'ї, та рівних і невід'ємних їх прав є основою свободи, справедливості і загального миру...» [10]. Особливістю як тексту самої Декларації, так і текстів, ухвалених у подальшому інших інструментів міжнародного права $\epsilon$ те, що у всіх них поняття «людська гідність» не здобуло статусу окремого права у всій системі людських прав. У більшості міжнародно-правових актів людська гідність згадується в преамбулах як базова вихідна категорія, з якої виводяться основні людські права. Навіть Європейська Конвенція з прав людини 1950 року, як перший міжнародний договір, що набув юридично зобов'язальної сили, не містить не тільки такого окремого права, а й не містить взагалі прямого посилання на людську гідність.

Попри таке визнання на міжнародному офіційному рівні гідності кожної особистості, навіть сьогодні немає однозначного визначення цього поняття, адже не тільки в науковому дискурсі, а й у буденному світогляді панує термінологічна невизначеність. Незважаючи на те, що ідея гідності зазвичай розглядалася в контексті етичної теорії, останніми роками все більше дослідників акцентують увагу на її інших складниках, що є свідченням необхідності застосування міждисциплінарного підходу для сучасного етапу наукового пізнання. Гідність людини все частіше стає однією 3 основних концептів сучасних наукових розвідок у філософії, праві, політології, а також у біомедицині. Так, в одних випадках це поняття використовують для позначення соціальної цінності особистості, а в інших - все частіше вживають, коли 
йдеться про право людини на самостійне рішення, вимогу шанобливого ставлення та заборону приниження.

Сучасна філософія пропонує різні погляди та шляхи розв'язання проблеми гідності. В одних випадках критикується та спростовується ії евристичний потенціал, наголошуючи на неможливості бути основою для етичних обговорень 3 огляду на інституційну невизначеність (Стівен Пінкер) [11], в інших випадках, навпаки, захищають та обгрунтовують її непересічну роль у процесі пояснення та утвердження (Джеремі Волдрон) [12]. Низка авторів наголошують на тому, що змістовне навантаження терміна «людська гідність» визначається культурними особливостями та політичним режимом країни, в якій формуються власні погляди на гідність людини, що значною мірою віддзеркалює їі внутрішню моральну цінність. У такому разі гідність визначається в контексті суспільних цінностей, традицій і норм [13, с.83]. Такий підхід ставить під сумнів той факт, що гідність може виступати нормативною засадою прав людини. Але саме універсальність прав людини є тим, що відрізняє їх від культурних норм, які можуть бути абсолютно відмінними в різних суспільствах та змінними в межах одного суспільства, і це саме те, що відрізняє гідність від культурного поняття «честь», яке насамперед відсилає нас до ціннісних суджень про добро та зло, що притаманні різним культурам, суспільствам, релігіям. Тобто, визнаючи соціокультурну зумовленість концепту «гідність», водночас закладаються підвалини для спростування гідності людини або окремих соціальних груп на підставі певної культурної чи ідеологічної оцінки. Найбільш показовим прикладом у цьому контексті $\epsilon$ нацистська Німеччина [14, с. 2]. Культурні та політичні конфлікти, що відбувалися впродовж усього XX ст. і продовжуються вже в нинішньому, також відбуваються через зіткнення різних позицій щодо сприйняття гідності в різних культурах, коли захист, своєї гідності досягається шляхом приниження гідності інших, нехтування правами переможених. 
Видається першочерговим, щоб гарантувати світовий порядок, мир справедливість та процвітання, необхідно створити конституційний лад, заснований на моральному дискурсі людської гідності, щоб знизити напругу між націями різних культур [15, с. 2].

\section{2. Питання біоетики в контексті гідності людини}

Система цінностей і ставлення до них визначає рівень суспільного розвитку на основі активізації антропологічного чинника. Забезпечення виживання людства не може зводитись лише до піклування про фізичну оболонку його представників. Насправді це цілісний комплекс заходів, спрямованих на формування нового менталітету сучасної людини, що знаходить своє втілення у свідомих вчинках. Тому біоетику можна розглядати крізь призму не лише природничих, а й суспільних, зокрема правових, наук. Втручання людини в природу та у власне буття призвело не лише до науковотехнічного прогресу, а й до зміни аксіологічної парадигми та моделі сприйняття цілісності особи як тілесної і духовної істоти. Досить поширені останнім часом біоетичні уявлення про гідність людини в контексті проблем біоетики, принципи якої лежать в основі юридичних приписів, що регулюють відносини у сфері біотехнічних та соціальних досліджень, фактично виступають вираженням правової рівності та консолідують систему права навколо людини як істоти духовної, що має власну гідність і цінність. Термін «біоетика» вперше було введено у 1927 році Фріцем Ягром у статті «Біоетичний імператив» як поняття про моральні засади використання лабораторних тварин і рослин. Сучасне уявлення про біоетику (етику життя) запропоновано у 1970 році американським онкологом, біохіміком Ван Ренсселером Поттером у статті «Біоетика - наука виживання», в якій під цим поняттям розумілась галузь дослідження на межі етики, медицини, духовності та біологічних наук для 
Права людини в Україні та у зарубіжних країнах:

проблеми теорії та нормативно-правової регламентації

забезпечення гідної якості життя. Виникнення біоетики було зумовлено посиленням уваги до прав людини за умов створення новітніх медичних технологій, що породжують велику кількість проблем та потребують розв'язання як $з$ погляду права, так і з погляду моралі. Тому, за словами Папи Франциска, завданням біоетики, що має глобальний вимір, $\epsilon$ - «знешкодити суспільство 3 брудною працею смерті». І відправною точною для того щоб окреслити цінність людської особи, має бути не хвороба чи смерть, а, радше, «глибока переконаність у невідкличній гідності особи, такої, якою її любить Бог, гідності кожної особи на кожному етапі й у кожних обставинах її існування» [16].

Люди хочуть, щоб вони розглядались як гідні, а тому гідність визнається одним із інтересів людини поруч 3 тілесною цілісністю, що інші люди зобов'язані поважати. I вже від самої людини залежить міра втілення чи реалізації принципу людської гідності через інтерес у ії̈ суб’єктивне право. Основним моральним принципом біоетики $\epsilon$ «принцип поваги до прав і гідності люди», що змушує лікарів вирішувати конфліктні питання, до яких можна віднести права жінки на прийняття рішення про аборт i право плода на життя, прийняття рішення хворого про смерть у разі невиліковної хвороби і гуманізм медицини, неприродне штучне запліднення, генетичне модифікування (коректування) та клонування, припускання донорства органів без дозволу самого донора, сурогатне материнство, припинення медичної допомоги безнадійно хворому та інші. Незважаючи на те, що етика $\epsilon$ досить стійкою системою знань, вона передбачає вибір індивідуальної позиції щодо тієї чи іншої проблеми, оскільки медицина XX століття може маніпулювати життям людини, керувати ним. П. Хеберлє також підкреслює, що про поняття «гідність людини» можна вести мову стосовно всього ії життя - від народження до смерті. Але у ряді випадків цей принцип діє навіть до і після згадуваних подій. Прикладами можуть слугувати захист особистої гідності померлого і дискусія про права плоду в утробі матері. Через велику кількість суперечностей і 
сформувалась біоетика як система знань про межі дозволеного маніпулювання життям та смертю людини. Окрім того, поняття гідності людини розглядається в контексті розвитку нових технологій, зокрема у вимірі трансгуманізму, тому що багато питань майбутнього включатимуть застосування технологій з метою зміни та впливу на людську природу та організм [17, с. 45].

Моральною основою, на яку має спиратись сучасна біоетика, є вимоги Нюрнберзького кодексу 1947 року, що був сформульований у процесі судового процесу в справі 23 нацистських лікарів, звинувачених у військових злочинах і злочинах проти людства під час Другої світової війни. Висунуті судом «десять етичних i правових» вимог показували злочинний характер експериментів, що проводилися на людях. 3 часом, під впливом ідей Нюрнберзького кодексу було прийнято низки міжнародних документів, що регламентували експерименти на людях та виражали ідею занепокоєння міжнародної спільноти щодо нехтування повагою до внутрішньої свободи та недоторканості кожної окремої особи, зокрема серед них $\epsilon$ i ті, що стосуються безпосередньо захисту гідності особи: Міжнародний кодекс медичної етики (1949 року), Гельсінська декларація про права людини (1964 року), Загальна декларація ЮНЕСКО про біоетику та права людини, документи ООН про громадянські й політичні права, прийняті в 1966 році, «Конвенція про захист прав і гідності людини у зв'язку із використанням досягнень біології та медицини: концепція про права людини в біомедицині» (1996 року), Хартія основних прав Європейського Союзу (2000 року).

\section{3. Людська гідність як правова цінність}

Останнім часом все більшої актуальності набувають дослідження, в межах яких гідність есплікується як процес та результат конституювання людини взагалі, що повертає дискурс до метафізичного підходу, за яким гідність навіть 
за аморальним соціальним суб'єктом, життя якого визнається самоцінним. Саме з цієї позиції Юрген Габермас доводить, що гідність є вищим рангом цінності на службі інтегративної концепції прав людини. «Гідність, - зауважує дослідник, - це своєрідний сейсмограф політичної спільності; це портал, через який егалітарноуніверсальний зміст моралі імпортується в право; це поняттєвий шарнір, який з'єднує мораль рівнозначної поваги до кожного 3 демократичними правами декларацій». У своїй праці «Концепт людської гідності і реалістична утопія прав людини» він неодноразово наголошує, що «ідея прав людини отримує додаткове моральне навантаження у вигляді поняття людської гідності», підкреслює «моральне завантаження ідеї прав людини через поняття її гідності» та вказує на наявність «тісного зв'язку між цими концептами» [18].

Схожої позиції дотримується і Ганна Арендт, яка осмислює категорію гідності в контексті обмеження політичної свободи та людської здатності до дії, тиранії та небезпечних форм негуманності [19]. Таким чином, поняття людської гідності переносить моральну вимогу поваги до кожної людини в контекст державного громадянства. Світоглядна ідея гідності і прав людини перетворилась на своєрідний категоричний імператив, який забороняє перетворення людини на засіб для досягнення різних цілей і визнає її автономію як розумної істоти. У цьому контексті формується самоповага людини та визнається їі соціальна цінність. Самоповага кожного громадянина забезпечується тим, що він визнається іншими суб'єктом права як «право мати права». Німецький дослідник П. Хеберлє, відповідаючи на запитання, що таке гідність людини, стверджував, що потрібно керуватись тезою, згідно з якою сукупність індивідуально орієнтованих громадянських прав i обов'язків має дозволяти кожній людині стати, бути i залишатися особистістю, а від того, яким чином людина стає особистістю, залежить і розуміння її гідності. 
Конституційна держава реалізує принцип гідності людини, перетворюючи громадян 3 об'єкту впливу на активних суб'єктів діяльності [20, с. 22].

Відсутність однозначного підходу до розуміння змістовного навантаження ідеї гідності зумовлена переходом від розмов про людську гідність як моральне очікування людей до розмов про те, що належить людям через їхню приналежність до людства. Це антропологічний підхід до прав людини, за яким цінність людини сприймається як її особливе місце, як представника виду серед інших живих істот, що визначається окремими специфічними рисами, до яких належать і її потенційні можливості. Вони свідчать про можливість актуалізувати власний потенціал та жити у мирі із собою тільки за умов рівного відношення один до одного. Це суб'єктивний корелянт об'єктивної цінності людини. Саме з такої позиції розуміють гідність людини деякі автори, які наголошують на унікальності та неповторності людини, володінні нею особливими моральними та інтелектуальними якостями, що відповідають загальновизнаним моральним цінностям, значущості кожної особи як частки людської спільноти [21 с. 144].

У юридичній науці категорія «гідність» $\epsilon$ поняттям багатоаспектним, має чимало різних ознак, значень та виявляється у всіх сферах буття людини. Фактично право на людську гідність слід розглядати в позитивістському і природно-правовому сенсі. Одні автори розглядають гідність людини як сукупність особистих прав і свобод, реалізація яких дозволяє кожному бути особистістю. Це право також належить до позитивно визначених конституційних прав i свобод та забезпечує захист громадян від посягань з боку фізичних та юридичних осіб, а також самої держави.

Для інших дослідників гідність людини - це природне, невіддільне право кожного, воно належить до природних прав людини і $є$ однією з головних соціальних цінностей демократичного суспільства - цінністю, що на практиці слугує критерієм оцінки конституційності та законності 
актів, дій чи бездіяльності органів публічної влади, інших фізичних і юридичних осіб. Таким чином, у конституційній державі права людини (основою яких є гідність людини) $\epsilon$ ще одним ефективним засобом обмеження державної влади. Гідність $\epsilon$ невіддільною природною ознакою цивілізованої людини; вона взаємопов'язана 3 іншими правами та свободами особи та потребує правового регулювання та захисту. Фокусування на гідності як конституційній цінності знайшло своє місце в дослідженнях Аарона Барака, який наголошує на відносному (релятивному) характері людської гідності як цінності, що зумовлено особливостями різних цивілізацій [22]. Отже, можна сказати, що гідність людини потрібно розглядати не лише як засадничий конституційний принцип, а й невіддільне право кожної людини. Вітчизняна юридична наука досить непогано вивчила досвід європейської та американської доктрини природного права епохи Відродження (XVII-XVIII ст.), проте вона ще недостатньо вивчила історію становлення i розвитку доктрин природного права в Україні. Зокрема, тих доктрин, що сформувалися у 1960-1970-ті роки завдяки руху дисидентів-шестидесятників, які фактично стали новітнім українським Відродженням. Саме у філософських, політологічних, економічних та інших трактатах та літературних творах «шестидесятників» - Ю. Бадзя, I. Дзюби, М. Руденка, Є. Сверстюка, В. Стуса та багатьох інших - викладено основи природного права на повагу до гідності людини в тоді ще пострадянській Україні. Власне духовний спадок «шестидесятників» доводить, що гідність $\epsilon$ продуктом нашого власного історичного і духовного розвитку, а не якоїсь абстрактної доктрини чи запозичення, воно $\epsilon$ духовним імперативом, що має надправове значення і захищається у правовому порядку в демократичних країнах або шляхом мирних чи збройних революцій - у тоталітарних державах [23, с. 169-170].

Слід відзначити, що в Україні питання гідності людини мають особливе значення. Вітчизняний теоретик права 
Петро Рабінович наголошує, що гідність людини поєднує в собі раціональні та ірраціональні начала. Упроцесі безпосереднього застосування поняття гідності людини набуває таких конотацій: 1) філософська основа, елемент антропологічної концепції у праві; 2) морально-правовий стандарт; 3) елемент законодавчих дефініцій, що формулюється для досягнення конкретних цілей, відповідно до міжнародного правового акту; 4) стандарт, якому суперечить явище, що засуджується міжнародним правовим актом; 5) об'єкт протиправних порушень без одночасної вказівки таких порушень; 6) об'єкт можливих протиправних порушень з одночасною вказівкою на такі; 7) об'єкт державно-правового захисту; 8) ідеал, до якого має провести процес, підтримуваний цим міжнародним правовим актом [24, с. 170-171].

у конституційній доктрині людська гідність розуміється дуально як цінність та суб'єктивне публічне право. Низка статей Конституції України містить досить сумбурні посилання на людську гідність як на засадниче положення, надаючи їй характеристику як «соціальній цінності» поряд з людиною, її життям і здоров'ям, честю, недоторканістю та безпекою, хоча перераховані конституційні блага не $\epsilon$ однопорядковими щодо людської гідності, оскільки походять від неї або можуть бути навіть критерієм її обмеження (безпека), крім цього, Основний Закон не дає юридичного визначення цього поняття, залишаючи його доктрині і конституційній юриспруденції. Своєю чергою Конституційний Суд України, долучившись до тлумачення змісту людської гідності в рішенні від 29 грудня 1999 року № 11-рп/99 (справа про смертну кару), вказав, що невід'ємне право кожної людини на життя нерозривно поєднано 3 їі правом на людську гідність. Як основні права людини, вони зумовлюють можливість реалізації всіх інших прав і свобод людини і громадянина і не можуть бути ні обмежені, ні скасовані. (абзац другий пункту 6 мотивувальної частини Рішення 
Конституційного Суду України у справі за конституційним поданням 51 народного депутата України щодо відповідності Конституції України (конституційності) положень статей 24, 58, 59, 60, 93, 190-1 Кримінального кодексу України в частині, що передбачає смертну кару як вид покарання (справі про смертну кару) від 29 грудня 1999№ 11-рп/1999 [25]. Пізніше, враховуючи сучасну філософсько-правову доктрину, наявне міжнародне регулювання людської гідності та сучасні тенденції розвитку права загалом, Конституційний Суд розробити власне бачення розуміння людської гідності з тим, щоб у підвалини державного устрою України запровадити свої доктринальні правові позиції щодо тлумачення статей основного закону відносно зазначеного принципу. Так, у своєму рішенні № 5-p/2018 наголошує на тому, що людську гідність необхідно трактувати як право, гарантоване статтею 28 Конституції України, і як конституційну цінність, яка наповнює сенсом людське буття, $є$ фундаментальним для всіх інших конституційних прав, мірилом визначення їх сутності та критерієм допустимості можливих обмежень таких прав (абзац шостий підпункту 2.3 пункту 2 мотивувальної частини ) Рішення Великої палати конституційного Суду України у справі за конституційним поданням 49 народних депутатів України щодо відповідності Конституції України (конституційності) пункту 12 розділу 1 Закону України «Про внесення змін та визнання такими, що втратили чинність, деяких законодавчих актів України» від 28 грудня 2014 року № 76-VIII від 22 травня 2018 року № 5-p/2018 [26]. Таким чином, можна сказати, що у своєму рішенні Конституційний Суд вперше підкреслив подвійний характер людської гідності та визнав людську гідність тлумачним принципом для визначення обсягу конституційних прав, викладених в Конституції України. Варто зазначити, що пізнання людської гідності через інтерпретацію відповідних конституційних положень має 
безпосередній вплив на розвиток доктрини прав людини. Такий крок збагатив сучасну конституційну наукову думку України та сприяв виробленню правової доктрини щодо захисту людської гідності як ціннісно-духовної передумови буття людини.

Наведене опосередковано підтверджується унікальним значенням людської гідності, як засадничого, інтегрального та системотворчого принципу українського конституційного ладу. Як засадничий, цей принцип пронизує увесь текст Конституції України, він явно чи приховано присутній у всіх її розділах:

1) На чолі всієї системи конституційних положень стосовно людських прав проголошено, що «людина, іï життя і здоров'я, честь і гідність визнаються в Україні найвищою соціальною цінністю» (частина перша статті 3). Це така наша національна конституційна формула, адже наведене положення є втіленням однієї з провідних ідей доктрини природного права та стисло відтворює зміст концептуальних засад преамбули Всесвітньої декларації прав людини 1948 року з метою протидії зневажанню державою людською гідністю «...визнання гідності, яка властива всім членам людської сім'ї, і рівних та невіддільних прав є основою свободи, справедливості та загального миру». Однак конституція України більше приховує значення людської гідності, аніж виділяє його. Адже, попри те, що в українському основоположному акті було закріплено цю важливу ідею, практика суспільного розвитку в Україні двічі (під час масового руху опору, відомого у 2004-2005 рр. як «Помаранчева революція», а у 2013-2014 рр. - як «Революція гідності») засвідчила невідповідність політичного режиму вимогам, що висуваються змістом цієї статті. Активне становлення громадянського суспільства в Україні сприяє розумінню людьми своїх прав, ставить вимоги перед владою щодо їх ефективної охорони та захисту, а отже, сприяє 
Права людини в Україні та у зарубіжних країнах:

проблеми теорії та нормативно-правової регламентації

утвердженню людської гідності та їі реалізації у щоденному житті.

Крім цього, необхідно вказати і на те, що у конституційній формулі частини першої статті 3 поняття людської гідності віднесено до категорії «соціальної цінності», а не до того, що визначає онтологічний статус людини. До цієї ж категорії «соціальної цінності» рівнозначно віднесено і саму людину. Тому поки із тексту цієї статті Конституції України у словосполученні «соціальна цінність» не буде вилучено термін «соціальна» (стосовно самої людини та іï гідності), доти існуватиме формальна перешкода для того, аби можна було сприймати людську гідність як «право прав» чи як «вершину усієї системи основоположних прав», тобто як установчий принцип усієї системи основоположних прав $[27$, c. 75-76]. Саме на позиції недоречності та безпідставності розглядати людину та людську гідність «соціальними цінностями» стоїть Венеціанська Комісія [28].

2) Конституція України не вживає термін «природні» відносно прав та свобод, але в статті 21 встановлює, що «Усі люди $є$ вільні і рівні у своїй гідності та правах. Права і свободи $\epsilon$ невідчужуваними та непорушними». У зазначеній конституційній нормі поняття людської гідності самостійного і незалежного значення не отримало, сама стаття має утопічний характер, про неї мало хто пам'ятає, а тому на практиці органи публічної влади легко iї ігнорують, і проблема тут не стільки в тексті самої Конституції, а в тому, що Конституція зараз не $\epsilon$ орієнтиром для ухвалення рішень. На цей час це одна 3 найбільш порушуваних статей Конституції України.

3) Конституція України забороняє обмеження тих прав і свобод, які належать до природних і невідчужуваних. «Кожен має право на повагу до його гідності. Ніхто не може бути підданий катуванню, жорстокому, нелюдському або такому, що принижує його гідність поводженню чи покаранню» (стаття 28). Без визнання цього права з боку 
держави і забезпечення належного рівня його захисту людина не може бути ані повноправним, ані рівноправним членом суспільства. Однак у суспільному і державному житті тема людської гідності звучить дуже рідко, ніби у цьому питанні в Україні немає проблем. Насправді проблеми $\epsilon$, але пануюча нормативістсько-правова доктрина, що залишилась нам у спадок від Радянського союзу, через викривлене розуміння людської гідності розглядає це право суто формально, не бачить жодних проблем, оскільки у законодавстві право на людську гідність закріплено.

\section{Висновки}

Узагальнюючи викладене, можна зробити висновок, що людська гідність, започаткована як ідея, знайшла свій розвиток у філософському, медичному та правовому вимірі і сьогодні, відповідно до конституційного законодавства, здебільшого реалізується як абсолютна цінність та фундаментальне право людини. У демократичних країнах державні й правові інститути, закони й традиції грунтуються на ідеях автономії, гідності і цінності людської особистості і тому саме в такій площині право на людську гідність в Україні вимагає переосмислення та впровадження, оскільки йдеться про явище, яке визначає суспільний розвиток загалом. Слід наголосити, що саме право на повагу до гідності людини супроводжує реалізацію і захист всіх інших прав людини, займаючи центральну нормативну роль та забезпечуючи їх нормативну єдність, оскільки повага і захист гідності людини є умовою забезпечення її прав і навпаки. Це право автоматично, так чи інакше порушується у разі порушення будь-якого конституційного права людини. Адже i позбавлення життя, і катування, і незаконне позбавлення власності, і порушення права на освіту тощо - все це $\epsilon$ виявом неповаги до гідності людини. Але, звичайно, проблема лежить не тільки в юридичній площині, оскільки 
для забезпечення поваги та захисту гідності людини має працювати і механізм громадянського суспільства, адже у багатьох цивільних та кримінальних справах можна спостерігати порушення права на гідність, однак громадяни ставляться до цього здебільшого байдуже, або ні самі громадяни, ні їх захисники не розглядають ці порушення як такі, що порушують людську гідність, спираючись при цьому на інші правопорушення. I допоки в державі та суспільстві не з'являться звичаї, які формуватимуть позитивне ставлення до права на людську гідність як соціальну цінність, громадяни не захищатимуть це право, а правова держава, заснована на верховенстві права, не зможе бути побудована. Знайти правильне співвідношення між державним ладом та гідністю i правами людини є одним з основних завдань кожної влади.

\section{Список використаних джерел:}

1. Дойчик М.В. Ідея гідності в історії європейської філософії. Текст: монографія. Видання 2-ге, доповнене. Івано-Франківськ : Прикарпат. нац. ун-т ім. В. Стефаника, 2018. 394 c.

2. Becchi P., Il principio dignita umana, Morcelliana, Brescia, 2009. P. 19 in C. Scognamiglio, Dignita dell'uomo e tutela della personalita. 2014. P. $67 \mathrm{ff}$.

3. Vincenti U., Diritti e dignita umana, Lanersa, Bari-Rome, 2009, pp. 7 ff. in C. Scognamiglio, Dignita dell'uomo e tutela della personalita, in Giustizia Civile, 2014. p. $67 \mathrm{ff}$.

4. Аристотель. Сочинения: в 4-х т. Москва : Мисль, 1983. T. $4.830 \mathrm{c}$.

5. Грищук О.В. Людська гідність у праві: філософські проблеми. Київ : Атіка, 2007. 432 с

6. Kant I., The Metaphysics of Morals (II. Metaphysical first principles of the doctrine of virtue), Cambridge, 1996; K.T. Galvin, L. Todres, Dignity as honor-wound: an experiential and relational view, in Journal of Evaluation in Clinical Practice, 2015, pp. 410-418. 
7. Бачинін В.А. Філософія права: словник. Київ : Концерн «Видавничий Дім «Ін Юре», 2003.408 с.

8. Zhang Q. Human Dignity in Classical Chinese Philosophy Confucianizm, Mohism and Daoism. Springer, 2016. 217 p.

9. Barilan Y.M. Human Dignity, Human Rights and Responsibility. The New Language of Global Bioethics and Biolaw. MIT Press. 2012. 368 p.

10. Статут Організації Об'єднаних націй від 26.06.1945. URL: http://www.un.org/en/charter-united-nations/ Загальна декларація прав людини від 10.12.1948 року. URL: http://www.un.org/en/universal-declaration-human-rights/).

11. Pinker S. The stupidity of dignity - Concervative bioethics latest, most dangerous play. The New Republic. 2008. № 238. P. 168-180.

12. Waldron J. Dignity, Rank and Rights [Online]. The Tanner lectures on Values. The University of Utah. 2009. Vol. 28 P. 207-253. URL: https://tannerlectures.utah.edu/_documents/ a-to-z/w/Waldron_09.pdf.

13. Howard, R. Dignity, Community and Human Rights. Human Rights in Cross-Culturfl Perspective A Request for Consensus/ ed. by Abdullah Ahmed An-Naim. Philadelphia : University of Pennsylvania Press. 2010. P. 81-104

14. Macready J.D. Hanna Arendt and the Fragility of Human Dignity. Lexington Books, 2017. 158 p.

15. Zhang Q. Human Dignity in Classical Chinese Philosophy Confucianizm, Mohism and Daoism. Springer, 2016/ 217 p.

16. Новости Ватикана. URL: https://www.vaticannews.va 25.07.2018

17. Jotterand F. Human Dignity and Transhumanism Do Antro-Technological Devices Yave moral Status Online The American Journal of Bioethics. 2010. 10.7 Pp. 45-5. URL: http://dx.doi.org/10/1080/15265161003728795.

18. Габермас Ю. Концепт человеческого достоинства и реалистическая утопия прав человека. Вопросы философии. 2012 № 2. URL: http://vphil.ru/index.php?jhtion=com_ content\&task=view\&id $=474$. 
19. Menkec C., Dignity as the right to have rights: human dignity in Hannah Arendt, in M. Duwell, J. Braarvig, R. Brownsword, D. Mieth (eds.), The Cambridge Handbook of Human Dignity, cit., p. 332; S. BAER, Dignity, liberty, equality: a fundamental rights triangle of constitutionalism, in University of Toronto Law Journal, 2009, p. 443.

20. Государственное право Германии. Том 1. Москва : Институт государства и права ран, 1994. 312 с.

21. Колесова Н.С. Личные (гражданские) права и свободы. Права человека. Отв. ред. А.Е. Лукашева. Москва, 1999. $144 \mathrm{c}$.

22. Aharon Barak Human Dignity: The Constitutuonal Value and The Constitutional Right. The Oxford handbook. Comparative constitutional law. Oxford, U.K. Oxford University Press 2012, P. 361-380.

23. Головань І., Кампо В. Повага і захист гідності людини в Україні: проблеми впровадження європейської моделі. Право України. 2015. № 2. С. 163-185.

24. Рабінович П.М. Права людини: соціальноантропологічний вимір:колективна монографія. Праці Львівської лабораторії прав людини і громадянина. Львів : Вид-во «Світ», 2006.

25. Орзіх М., Єзеров А., Терлецький Д. Конституція України у судових рішеннях. Київ : Юрінком Інтер. $€ 2011.432$.

26. Рішення Великої палати конституційного Суду України у справі за конституційним поданням 49 народних депутатів України щодо відповідності Конституції України (конституційності) пункту 12 розділу 1 Закону України «Про внесення змін та визнання такими, що втратили чинність, деяких законодавчих актів України» від 28 грудня 2014 року № 76-VIII від 22 травня 2018 року № 5-p/2018. URL: http://zakon.rada.gov.ua/laws/show/ v005p710-19.

27. Головатий С. Тріада європейських цінностей верховенство права, демократія, права людини - як основа 
Права людини в Україні та у зарубіжних країнах:

проблеми теорії та нормативно-правової регламентації

українського конституційного ладу. Право України. Юридичний журнал. 2015. № 1. С. 13-91.

28. Opinion on the Constitution of Ukraine adopted by the Commission at its 30th Plenary meeting in Venice on 7-8 March 1997 on the basis of the contributions submitted by $\mathrm{Mr}$ S. Bartole (Italy), Mr G. Batlliner (Liechtenstaine), Mr J. Klucka (Slovakia), Mrs A. Milencova (Bulgaria), $\mathrm{Mr}$ H. Stainberg (Germany), Mr A. Delacamp (CLARE) Strasburg, 11 March 1997. Doc.CDL-INF (97) 2. 
Права людини в Україні та у зарубіжних країнах:

проблеми теорії та нормативно-правової регламентації

DOI https://doi.org/10.36059/978-966-397-210-7/208-228

Козакевич О. М.,

аспірантка кафедри загальнотеоретичної юриспруденції Національного університету «Одеська юридична академія»,

м. Odeca

\section{ОСОБЛИВОСТІ РЕАЛІЗАЦІЇ ПРАВА НА ДОСТУП ДО ПРАВОСУДДЯ У ТРАНЗИТИВНИХ УМОВАХ}

Анотація. Це дослідження присвячене аналізу сучасних тенденцій реалізації права на доступ до правосуддя. Процес реалізації права на доступ до правосуддя в теперішній ча, характеризується певними особливостями. Для Украӥни, наприклад, це пов'язано із транзитивним періодом, в якому перебуває суспільство. Під впливом транзитивних процесів система правосуддя зазнає значних трансформацій. Одним із напрямків таких змін $\epsilon$ формування сучасної концепції доступності правосуддя. Основна ідея даної концепції полягає у формуванні такої системи правосуддя, яка, в першу чергу, буде сприяти зменшенню організаційних бар'єрів для належної реалізації громадянами права доступу до правосуддя. Важливим аспектом щодо досягнення даної мети слід вважати впровадження новітніх інформаційних технологій у судочинстві.

\section{Вступ}

Право є відображенням глибинних тенденцій і процесів, що відбуваються як у кожному окремому суспільстві, так у світі в цілому. Під впливом викликів сучасності виникає потреба орієнтуватись не тільки на традиційний досвід у правовій сфері, але і враховувати динамічні зміни в суспільстві, пов'язані із транзитивними процесами. Транзитивний період $\epsilon$ перехідним етапом розвитку будьякого суспільства. Транзитивність характеризується зміною ціннісно-нормативних орієнтирів, під впливом яких змінюються основні соціальні і правові інститути. 
Забезпечення прав та свобод людини є основоположною ідеєю існування сучасної держави, певним стандартом демократії, основою формування громадянського суспільства. Саме тому одним із проявів транзитивності у правовій сфері $\epsilon$ зміни, що відбуваються $\mathrm{d}$ системі правосуддя i, в першу чергу, в аспекті його доступності.

Право на доступ до правосуддя в системі прав людини має першорядне значення, оскільки являє собою систему правомочностей, які спрямовані на реалізацію та захист всіх інших прав, свобод та інтересів людини. У сучасних умовах реалізація права на доступ до правосуддя пов'язана із транзитивними процессами, що відбуваються в державі. Ці зміни детермінують правовий розвиток, зумовлюють специфіку сучасного права. Значних трансформацій зазнають механізми правореалізації, правозастосування. Зміни ціннісних орієнтирів впливають на рівень правової культури та правосвідомості в суспільстві. Усе це впливає на умови здійснення судочинства, спрямовує зусилля держави на забезпечення та дотримання демократичних принципів у судовому процесі, актуалізує важливість забезпечення права кожної людини на доступ до правосуддя.

Слід зазначити, що в сучасній Україні виникають певні проблеми 3 належною реалізацією права на доступ до правосуддя. Саме тому сьогодні $\epsilon$ важливим аналіз шляхів подолання зазначених проблем, а також вивчення позитивного досвіду інших країн щодо організації системи правосуддя, та безумовної реалізації права на доступ до правосуддя.

\section{1. Забезпечення права на доступ до правосуддя як складник сучасних трансформаційних процесів}

Світ $\epsilon$ сукупністю надзвичайно різноманітних суспільств, правових систем, що взаємодіють, проте співіснування яких постійно видозмінюється під впливом тенденцій і викликів часу. Людство пройшло 
Права людини в Україні та у зарубіжних країнах:

проблеми теорії та нормативно-правової регламентації

доіндустріальну та індустріальну стадії розвитку. 3 останньої чверті XX ст. настав перехідний період до постіндустріального, або інформаційного суспільства.

У кожну історичну епоху формувався свій тип праворозуміння, який зумовлював особливості формування та розвитку національних правових систем. Індустріальна епоха характеризувалась промислово розвиненою системою, визначала індивідуалістичну спрямованість правових інститутів, важливість прав і свобод особистості, визначне місце закону. Західне індустріальне суспільство, орієнтирами якого були гедонізм та прагматизм, досягло значних успіхів, що дозволило не лише технологічно, а й світоглядно претендувати на домінуючі позиції у світі. Людина індустріального суспільства була спрямована на матеріальні цінності, що призвело до духовної кризи того часу. Перехід до постіндустріального суспільства, з його новітніми цінностями i спрямованістю на всебічний розвиток людини, сприяє подоланню цього кризового стану.

Взагалі термін «постіндустріальне суспільство» вперше було вжито після Другої світової війни американським юристом та соціологом Девідом Рісменом у 1958 році $[1$, c. 364]. У соціальних науках для позначення даного типу суспільства використовуються також поняття «інформаційне суспільство» (Й. Масуда), «технотронне суспільство» (3. Бжезинський), «наукове суспільство» (М. Понятовський), «суперіндустріальна цивілізація», «третя хвиля» (Е. Тоффлер). Значний теоретичний внесок у розробку концепції нового суспільства було зроблено Д. Беллом у його праці «Прийдешнє постіндустріальне суспільство», в якій визначено, що постіндустріальне суспільство робить наголос на центральній ролі теоретичного знання як осі, навколо якої вибудовується нова технологія та розвиток всіх соціальних сфер [2, с. 50].

Базисом постіндустріального суспільства $€$ знання, що не віддільні від людини. Це й зумовило підсилену увагу до людини, ïi інтелектуальних здібностей, прав та свобод. Саме в сучасний період актуалізувались питання визнання 
та захисту прав людини. Це призводить до суттєвих змін у правовій сфері, а саме до формування і розвитку інституту захисту прав людини та його нормативно-правової регламентації. Крім того, на межі XX - XXI ст. з'явилась концепція формування «Knowledge society», «К-суспільства» або «суспільства, заснованого на знаннях». Це суспільство, яке визначається як вищий ступінь розвитку постіндустріального суспільства та характеризується, крім технологічного, соціальним, ідеологічним та правовим вимірами [3, с. 245-355]. Його невід'ємними компонентами стали міждисциплінарні знання, що генеруються соціальними та правовими інститутами, i суспільство, зорієнтоване на підвищення якості життя та належної реалізації громадянами усіх їхніх прав.

Постіндустріальний світ перебуває лише на початковому етапі становлення. Саме тому у великій кількості держав відбуваються трансформаційні зміни по переходу від авторитарних та тоталітарних форм правління до демократії та від індустріального до інформаційного суспільства. Зазначений період визначається як транзитивний.

Термін «транзиція» $\epsilon$ найбільш узагальнюючим по відношенню до таких категорій, як «перехід» i «трансформація», та вказує на незавершеність руху, процес, спрямований у майбутнє [4, с. 14]. Транзитивний процес являє собою динамічний перехід суспільства та основних соціальних інституцій на новітній ступінь розвитку. Він $\epsilon$ історичною закономірністю, але слід зазначити, що перехід на прогресивно новий рівень розвитку часто ускладнюється внутрішніми протиріччями. Статичні компоненти, що властиві попередньому періоду розвитку суспільства, заважають позитивним перетворенням.

Транзитивне суспільство визначають як певний етап розвитку суспільства, що характеризується суттєвою трансформацію усіх або більшості соціальних інститутів, цінностей та норм, які зумовлюють виникнення нових 
соціальних структур та змін в організації управління суспільством, якому властиві такі ознаки: невідповідність соціальних інститутів реальним суспільним потребам; зміни у соціальній структурі; руйнування бар'єрів та виникнення нових; зміни ідентичності індивіда; трансформація соціальних інститутів, що включає їх деформацію, вдосконалення; зміни в організації управління суспільством; зміна цінностей $\epsilon$ особливо важливим компонентом транзитивного періоду в житті суспільства; зміна нормативного регулювання [4, с. 15].

Свій прояв транзитивність знаходить у правовій сфері. Транзитивність $\epsilon$ закономірною властивістю права, що проявляється в рефлексії права на соціальну транзицію та в закріпленні результатів соціальної транзиції правовими засобами [4, с. 7]. Під впливом цих тенденцій здійснюється розвиток нормативної сфери права, формуються нові за змістом правові норми, інститути, галузі, змінюється система правореалізації та правозастосування.

Особливості формування права в транзитивний період зумовлюються орієнтиром на ідеали сучасного правового розвитку. Із цією метою нормативно закріплюються нові правові цінності, трансформуються, а то й відкидаються усталені правові позиції, впроваджуються у свідомість нові правові установки. Особливу роль у транзитивний період відіграє правоутворення, яке залежить від взаємодії цінностей різного рівня, від загальнолюдських до цінностей соціальної та/або етнічної групи [4, c. 21]. До загальнолюдських цінностей слід віднести, перш за все, права людини, які особливо гостро сприймаються у транзитивних суспільствах, що долають наслідки тоталітаризму або авторитаризму.

Транзитивні зміни знайшли своє відображення в системі правосуддя, а саме в доступності правосуддя як однієї 3 його центральних характеристик. Доступність правосуддя втілює механізм реалізації одного з основних прав людини - права на захист своїх законних прав та 
інтересів за допомогою правосуддя як найбільш демократичного та ефективного інструменту захисту.

Аналіз положень міжнародного та національного законодавства свідчить про те, що гарантія доступності правосуддя встановлюється як на міжнародному рівні в нормативно-правових актах, дію яких визнано Україною, так i на державному рівні шляхом закріплення в положеннях основного закону держави - Конституції України, та в інших нормативно-правових актах українського законодавства. Так, ст. 6 Конвенції про захист прав людини та основоположних свобод 1950 року (далі Конвенція) передбачено, що кожен має право на справедливий і публічний розгляд його справи впродовж розумного строку незалежним і безстороннім судом, установленим законом, який вирішить спір щодо прав та обов'язків цивільного характеру або встановить обгрунтованість будь-якого висунутого проти нього кримінального обвинувачення [5]. Відповідно до ст. 55 Конституції України кожному гарантується право на оскарження в суді рішень, дій чи бездіяльності органів державної влади, органів місцевого самоврядування, посадових і службових осіб [6]. Вказані правомочності в юриспруденції розглядаються як складові частини права на доступ до правосуддя.

Слід зазначити, що ні Конвенція, ні норми національного законодавства України не дають визначення «права на доступ до правосуддя». Водночас вказане поняття досить широко застосовується у судовій практиці та правовій доктрині. Національні суди керуються, зокрема, дефініціями Європейського суду з прав людини, який визначає право на доступ до правосуддя 3 огляду на реальну можливість реалізації низки процесуальних прав:

- на звернення до суду за захистом своїх прав, свобод та законних інтересів (рішення у справі «Голдер проти Сполученого Королівства» [7]); 
- на ефективну участь у провадженні (рішення у справі «Лучанінова проти України» [8]);

- на оскарження судових рішень, якщо закон передбачає створення апеляційних та/або касаційних судів (рішення у справі «Гоффман проти Німеччини» [9]);

- на виконання рішень (рішення у справі «Аннонні ді Ґюссоль та інші проти Франції» [10]) тощо.

Практика Європейського Суду із прав людини (ЄСПЛ) з питань доступності правосуддя бере свій початок зі справи Голдер проти Сполученого Королівства (справа Голдера) від 21 лютого 1975 р. Дане рішення закріпило фундаментальні основи права на доступ до правосуддя. Концептуальною ідеєю рішення у справі Голдера $\epsilon$ «право доступу», в якому ЄСПЛ фактично вперше вивів з тексту Конвенції зазначене право. Формування категорії «доступності правосуддя» стало можливим внаслідок того, що Суд розглянув судовий процес не шляхом текстуального тлумачення статті 6 Конвенції, а перш за все крізь призму ефективності правового захисту. Заперечення існування доступу до правосуддя могло б привести як до неефективності статті 6 Конвенції, так і загалом до обмеження доступу до системи захисту прав людини. На цей факт вказує і сам Європейський Суд з прав людини, відзначаючи у справі Голдера, що право на доступ до суду охоплює не тільки вже розпочатий процес, але і саму можливість ініціювати судову процедуру [7]. Як наслідок, в юриспруденції справа Голдера цілком обгрунтовано ототожнюється 3 конкретизацією права на доступ до правосуддя та стала основою для осмислення теоретичних питань доступності правосуддя та зародження ряду правових доктрин.

У сучасних наукових дослідженнях право на доступ до правосуддя розглядають у вузькому та широкому сенсах. У вузькому сенсі - як можливість скористатися правовими засобами класичного правосуддя або лише як формальну можливість особи з'явитися в суді. Так, Ю. Матат під 
доступом до правосуддя розуміє здатність особи безперешкодно отримати судовий захист як доступ до незалежного й безстороннього вирішення спорів за встановленою процедурою на засадах верховенства права $[11$, c. 20]. На думку I. Верби, право на доступ до правосуддя слід визначати як право людини, що передбачає можливість безперешкодного звернення до суду з метою захисту своїх прав, свобод [12, с. 20].

За широкого підходу право на доступ до правосуддя припускає необхідність подолання різних бар'єрів в системі правосуддя та пов'язане із соціально-економічним контекстом. В умовах транзитивних змін пріоритетним $\epsilon$ широке розуміння досліджуваного поняття. Право на доступ до правосуддя в цьому випадку розглядається через сутність та призначення категорії «правосуддя», а не лише у площині «доступності», оскільки передбачає реальний характер судового захисту та включає в собі змістовні характеристики правосуддя, а не лише окремі правомочності та організаційні аспекти. Саме за такого підходу право на доступ до правосуддя буде забезпеченим та реалізованим в повній мірі.

Слід відзначити, що під впливом транзитивних процесів у правовій сфері відбулося формування повноцінної теоретичної концепції правосуддя в 70-ті роки XX століття, яке пов'язане із втіленням «Флорентійського проекту». Основна мета Флорентійського проекту полягала у формуванні сучасної теорії доступності правосуддя. Iї базисом стала робота професора Мауро Каппеллетті «Доступність правосуддя». Основною ідеєю зазначеної роботи $\epsilon$ зміна теоретико-правового підходу до правосуддя. М. Каппеллетті критикував домінуючий в той час ліберально-буржуазний підхід до права і правосуддя, який передбачав формалізоване розуміння права на доступ до правосуддя. Відповідно до цього підходу держава не заперечує факт існування природних прав, проте не вживає дій, спрямованих на сприяння в їх реалізації. 
Права людини в Україні та у зарубіжних країнах:

проблеми теорії та нормативно-правової регламентації

Досягненням М. Каппеллетті був розгляд природи бар'єрів у доступі до правосуддя. 3 одного боку, він визнавав, що певні бар'єри під час звернення до суду повинні бути: доступ до суду не може бути хаотичним, тому процедура звернення до суду повинна бути так або інакше врегульована. 3 іншого ж боку, такі бар'єри не повинні порушувати права людини, оскільки $є$ ймовірність того, що право на доступ до правосуддя стане лише формальним, а його реалізація неможливою. Серед подібних бар'єрів, М. Каппеллетті виділяв організаційні, фінансові, економічні та адміністративні перешкоди.

Одним із підсумків Флорентійського проекту став «рух за доступ до правосуддя» - як комплекс заходів, спрямованих на забезпечення реального характеру доступу до правосуддя. Такі заходи М. Каппеллетті класифікував на три групи, які назвав «хвилями». Кожна «хвиля», по суті, була похідна від бар'єрів, що перешкоджали доступу до правосуддя: 1) усунення соціальних перешкод (реформування ринку юридичної допомоги, оптимізація системи розподілу судового збору); 2) реформування інститутів захисту прав різноманітних груп осіб; 3) впровадження систем альтернативного вирішення спорів. Саме завдяки М. Каппеллетті багаточисельні ідеї щодо доступності правосуддя були систематизовані і зведені в єдину концепцію. Відмінною рисою даної концепції $€$ не тільки ії теоретична значущість та міждисциплінарний характер (вона поєднує напрацювання філософії, соціології, юриспруденції), але і її практична спрямованість [13, с. 196].

Сучасний структурований підхід щодо права на доступ до правосуддя запропонувала Крістін Паркер, яка виділяє чотири покоління підходів до розуміння та реформування вказаного права:

- доступ до правосуддя як рівний доступ до правової допомоги та судів через надання відповідних державних субсидій та іншої правової підтримки; 
- доступ до правосуддя як усунення дисбалансу в межах системи правосуддя, що виражений у зміні законів та судових процедур, судової практики 3 метою забезпечення чіткого порядку реалізації вказаного права;

- доступ до правосуддя, що охоплює широке застосування змагальних та незмагальних альтернатив класичного правосуддя;

- поліпшення доступу до правосуддя шляхом створення відповідного конкурентного середовища, що дало б змогу забезпечити доступ до правосуддя найбільш продуктивно, наприклад, шляхом реформи юридичної професії для зменшення вартості правової допомоги $[14$, c. 30$]$.

Через реалізацію прав розкриває поняття права на доступ до правосуддя i Конституційний Суд України в своєму рішенні від 12.04.2012 р. № 9-рп/2012 [15]. У цьому рішенні зазначається, що право на доступ до правосуддя охоплює можливість особи ініціювати судовий розгляд та брати безпосередню участь у судовому процесі. При цьому наголошується на тому, що ніхто не може бути обмежений у такому праві або його позбавлений.

\section{2. Шляхи реалізації права на доступ до правосуддя в сучасних умовах}

Після 1991 року в Україні було розпочато курс на побудову суспільства, заснованого на демократичних засадах. Проте українське суспільство сьогодні ще знаходиться у стані глибокої, системної кризи, пов'язаної з особливостями транзитивного періоду розвитку держави. Так, наявність лише декларативних гасел, а не реальних змін, зумовлює втрату довіри громадян до правових інститутів, системи правосуддя, правоохоронних органів, що призводить до розповсюдження нігілістичного ставлення до права.

Одна із центральних ідей зміни концепції правосуддя в транзитивний період полягає в тому, що суспільство 
Права людини в Україні та у зарубіжних країнах:

проблеми теорії та нормативно-правової регламентації

перебуває між станом, коли мали місце численні порушення прав людини, і станом стабільності й миру. При цьому постконфліктні, поставторитарні обставини $\epsilon$ достатньо значними чинниками інституційної реформи. Адже державна влада перебуває у глибокій кризі, а інституційна складова частина фрагментована $[16$, с. 8]. В юриспруденції виділяють певні внутрішні фактори, що визначають ефективність змін у доступі до правосуддя в поставторитарних суспільствах:

1) демократія - демократичні режими більш спрямовані на встановлення рівності, справедливості, оскільки засновані на засадах відкритості урядування й прагненні задовольнити вимоги суспільства; здійснення правосуддя над тим, хто винен у масштабних порушеннях прав людини;

2) визнання та захист прав людини - реагування на масштабні порушення прав людини в минулому, повага держави до концепції прав людини в цілому створює належні передумови для ефективних механізмів правосуддя;

3) співвідношення владних сил попереднього режиму, з одного боку, і громадянського суспільства, з іншого, - від такого співвідношення залежить ефективність механізмів правосуддя в період транзитивності;

4) рівень громадської підтримки попереднього режиму $[16$, c. $10-11]$.

Права та свободи людини $€$ основним цінніснонормативним орієнтиром сучасних демократичних трансформацій суспільства. Право на доступ до правосуддя має першорядне значення серед усіх індивідуальних та колективних прав, оскільки являє собою механізм їх захисту. У транзитивних умовах посилюється роль держави в забезпеченні комплексу заходів, спрямованих на реалізацію громадянами права на доступ до правосуддя. Перш за все, це полягає в неприпустимості встановлення державою будь-яких організаційних, економічних, 
перешкод на шляху до правосуддя. Ці бар'єри не повинні порушувати права людини, оскільки є ймовірність того, що право на доступ до правосуддя стане лише формальним, а його реалізація неможливою. Тобто роль держави в забезпеченні права на доступ до правосуддя має полягати як в утриманні від учинення фактичних та адміністративних перешкод у його реалізації, так і в активних діях, орієнтованих на створення та спрощення процедури забезпечення цього права. Процес взаємодії держави та особи є одним із індикаторів стану суспільних змін на шляху до втілення загальнолюдських цінностей.

Аналіз резолюцій і рекомендацій Комітету Міністрів Ради Європи дозволяє вирізнити такі критерії доступності правосуддя:

- обов'язок держави забезпечити надання адвокатом високопрофесійної правової допомоги особам, які через скрутний матеріальний стан не в змозі їі самостійно оплатити;

- інформування громадськості про юрисдикцію та місцезнаходження судів, а також про порядок звернення до суду для захисту своїх прав, свобод та інтересів у судовому порядку;

- застосування спрощених судових процедур;

-скорочення або анулювання судових витрат, якщо вони стають перешкодою для доступу до правосуддя;

- вжиття заходів, спрямованих на усунення зловживань правом особи на звернення до суду;

- забезпечення судових органів найсучаснішими технічними засобами;

- використання альтернативних засобів розв'язання правових конфліктів із поступовим зменшенням завдань, не пов'язаних із вирішенням спору про право, які покладаються на суд;

- створення сучасних автоматизованих систем зберігання судових рішень із забезпеченням належного доступу до них; 
Права людини в Україні та у зарубіжних країнах:

проблеми теорії та нормативно-правової регламентації

- вжиття заходів, спрямованих на підвищення ефективності управління інфраструктурою, фінансами, людськими ресурсами й засобами зв'язку в системі правосуддя;

- гарантії незалежності та неупередженості суддів під час здійснення правосуддя [16, с. 459].

Ураховуючи реалії функціонування, та розвитку правової системи України, слід зазначити, що певна частина зазначених критеріїв щодо доступності правосуддя не забезпечується належним чином. Навпаки, виникають певні обмеження в механізмі реалізації громадянами права на доступ до правосуддя.

Сучасне українське правосуддя характеризується інституційними змінами. Офіційно судова реформа в Україні почалася в 2014 році, орієнтиром якої було досягнення стандартів Європейського Союзу. Процес реформування супроводжувався прийняттям Верховною Радою України низки законодавчих змін, основні положення яких відображені в таких нормативно-правових актах: Закон України «Про забезпечення права на справедливий суд» від 12 лютого 2015 року, Закон України «Про судоустрій і статус суддів», Закон України «Про внесення змін до Конституції України(щодо правосуддя)» від 02 червня 2016 року, Закон України «Про внесення змін до Господарського процесуального кодексу України, Цивільного процесуального кодексу України, Кодексу адміністративного судочинства України та інших законодавчих актів» від 03 жовтня 2017 року.

Реформа правосуддя в Україні повинна була мати спрямованість на забезпечення реального втілення в життя прав і свобод людини. Проте її реалізація не сприяла розширенню механізмів доступу до правосуддя. Навпаки, українська система правосуддя зберегла каральну спрямованість та бар'єри в доступі громадян до правосуддя. 
Одним із напрямів судової реформи було втілення закріпленого в Конституції, належного функціонування судової системи як однієї із трьох незалежних гілок влади. Для цього передбачалося повністю вилучити вплив політичних чинників на призначення суддів, позбавивши орган законодавчої влади даної функції. У результаті прийняття законів «Про внесення змін до Конституції України (щодо правосуддя)» i «Про судоустрій i статус суддів» право призначати суддів перейшло до президента. Наявність у процедурі кваліфікаційного оцінювання добору суддів такого суб'єктивного елемента, як співбесіда із членами Вищої кваліфікаційної комісії суддів, на яку вирішальний вплив має президент, продовжує тенденцію посилення контролю інших гілок влади над судовою системою $[17$, c. 205]. Таким чином, через політичний вплив на судову систему порушується гарантія незалежності суддів, що є одним із елементів доступності правосуддя.

Ще одним результатом реформування правосуддя $є$ той факт, що витрати на функціонування судової системи збільшуються, а не зменшуються, всупереч задекларованим цілям реформи. Значна частка судових витрат йде на процеси реорганізації судів та проведення кваліфікаційних перевірок суддів, ефективність яких вкрай сумнівна, зважаючи на кадровий дефіцит суддів. Ці факти призводять до того, що деякі суди існують лише фактично, не здійснюючи при цьому правосуддя.

Проте найбільше перешкод у реалізації громадянами права доступу до правосуддя пов'язано із прийняттям Закону України «Про внесення змін до Господарського процесуального кодексу України, Цивільного процесуального кодексу України, Кодексу адміністративного судочинства України та інших законодавчих актів» від 03 жовтня 2017 року, який встановив ряд бар'єрів доступу до справедливого і незалежного правосуддя. Одним із таких бар'єрів стало зростання розміру судового збору, який збільшився в десятки разів із прийняттям нового 
законодавства. Ставки судового збору настільки великі, що позбавляють більшість громадян можливості звертатись до суду. Крім того, в разі невнесення стороною спору, коштів судового збору суд має право залишити позов без розгляду. Усе це обмежує право доступу громадян до правосуддя, ставить його в залежність від матеріального становища особи.

Суттєвих обмежень зазнають громадяни під час реалізації доступності правосуддя на касаційному етапі розгляду справ. Відповідно до ст. 328 Кодексу адміністративного судочинства України судові рішення у справах незначної складності не підлягають касаційному оскарженню, крім випадків, визначених у тексті Кодексу такими «оціночними» категоріями, як: фундаментальне значення; значний суспільний інтерес; виняткове значення для учасника справи [18]. Ці поняття не розтлумачені в тексті закону, що позбавляє громадянина гарантованого права на доступ до правосуддя. Крім того, Касаційному адміністративному суду надаються повноваження визнання касаційної скарги необгрунтованою ще до стадії іiї розгляду. Таким чином, можуть виникати ситуації, коли аналогічні справи будуть переглядатися в касаційному порядку залежно від певного складу суду, а не наявності законних підстав для такого перегляду. Це в підсумку впливатиме на гарантію неупередженості суддів.

Значною перешкодою в доступності правосуддя стало закріплення нормативного положення про те, що суд може не проголошувати публічно судові рішення, прийняті за результатами закритих судових засідань, що порушує статтю 6 Конвенції із прав людини, де вказано, що судові рішення в будь-якому випадку проголошуються публічно $[17$, c. 200].

Слід зазначити, що в сучасній Україні правосуддя характеризується наявністю негативних тенденцій не лише в аспекті реалізації кожним громадянином права доступу до правосуддя, а й загалом відносно всієї системи правосуддя. Визначається відставання правосуддя від 
прогресивних правових вимог суспільства. У нормативноправових актах, що регулюють суспільні відносини у сфері забезпечення здійснення правосуддя, велика кількість формулювань, які порушують конституційну вимогу для органів влади діяти лише на підставі і в рамках закону: «суд може», «суд має право», «визнається судом», «за ініціативою суду», «суд сприяє примиренню сторін» $[17$, с. 204]. У цьому випадку закон виходить за межі права і стає знаряддям свавілля, який зумовлює регресивний розвиток правової сфери.

Одним із важливих кроків на шляху до ефективної реалізації громадянами права на доступ до правосуддя в сучасний, транзитивний період слід вважати впровадження новітніх інформаційних технологій у систему правосуддя.

Новації сучасної доби багато в чому пов'язані із втіленням новітніх інформаційних технологій у процеси обробки правової інформації та прийняття юридично значущих рішень. Наприклад, з'являються такі процеси та явища, як електронне урядування, електронна демократія, електронний документообіг, електронний суд та ін. Під впливом динамічних процесів інформатизації активно застосовуються інформаційні технології в судовій системі та судочинстві. Ці фактори зумовлюють формування електронного правосуддя, що суттєво змінює правосуддя в контексті його доступності.

Електронне правосуддя являє собою певну систему, що складається 3 елементів, які забезпечують доступ до інформації про діяльність судів і систем автоматизації судочинства. Основна мета електронного правосуддя полягає в забезпеченні безперешкодної реалізації громадянами права доступу до правосуддя, спрощенні провадження низки процесуальних дій для громадян. У цьому контексті важливого значення набувають положення кримінального процесуального законодавства. Зокрема, Кримінальний процесуальний кодекс України передбачає застосування відеоконференції під час 
досудового розслідування у процесі проведення допиту, впізнання. Стаття 232 КПК України детально регламентує умови застосування цієї технології та ії процесуальне оформлення. Хід i результати процесуальних дій, проведених у режимі відеоконференції, фіксуються за допомогою технічних засобів відеозапису [19].

У ряді випадків такі технології роблять доступ до суду єдиним можливим способом. Як наслідок, право на доступ до правосуддя розглядається не лише як фізична можливість особи бути присутньою в судовому засіданні, а в аспекті новітніх технологій, дій і процедур допоміжного характеру щодо забезпечення i полегшення шляхів реалізації права на доступ до правосуддя [16, с. 371]. Слід зазначити, що право на доступ до правосуддя в цьому аспекті розглядається не лише як правова категорія, a i крізь призму соціального контексту, в якості соціальної категорії, що оперує насамперед загальнолюдськими цінностями і правом кожної особи на захист своїх прав, свобод та законних інтересів. Як наслідок, реалізація права на доступ до правосуддя розглядається як шлях до вирішення соціальної несправедливості.

Україна теж знаходиться на шляху до формування системи електронного правосуддя. Значне місце в роботі судів має реалізація проекту «Електронний суд», що запроваджує обмін електронними документами між судом та учасниками судового процесу [20]. Адже ведення та збереження документації суду в електронному вигляді забезпечить безперешкодне право на доступ громадян до правосуддя навіть у разі припинення робити суду за об'єктивних (надзвичайних) обставин та подальшого територіального переміщення судової установи в іншу місцевість.

Наразі перші кроки в напрямку реалізації проекту «Електронний суд» в Україні вже зроблені. Електронна підсистема суду працює у відкритому доступі ESITS та забезпечує безпечний обмін файлами, що стосуються того чи іншого судового процесу через електронний кабінет. 
Безперечно, впровадження таких новацій сприятиме зменшенню організаційних, адміністративних та часових витрат, що виникають під час подання процесуальних документів до суду в паперовій формі. До того ж електронне судочинство забезпечить учасникам справи право брати участь у судовому засіданні незалежно від їхного місця перебування (місця проживання). Такі зміни сприятимуть усуненню організаційних бар'єрів громадян до реалізації права на доступу до правосуддя, що сприятливо відобразиться на всій системі правосуддя та зумовить позитивні тенденції на правосвідомості суспільства.

Проте в деяких випадках новітні технології можуть значно обмежити реалізацію доступу до правосуддя. Це може стосуватись, наприклад, осіб, які не володіють навичками роботи із сучасними інформаційними технологіями або не мають відповідного технічного обладнання. У такому випадку право на доступ до правосуддя буде значно звужено, а за відсутності фінансових можливостей отримати професійну допомогу взагалі стає неможливим. 3 урахуванням даного фактора встановлення електронної судової комунікації як єдиної форми спілкування учасників судового процесу, коли право використання електронних технологій переходить в обов'язок, буде створювати надмірні перешкоди на шляху звернення до суду і обмежувати доступність правосуддя як можливість належної реалізації громадянами права на захист своїх прав, свобод та законних інтересів.

\section{Висновки}

Сьогодні Україна знаходиться в умовах перетворень, пов'язаних із транзитивним періодом її розвитку. На шляху побудови демократичного суспільства відбуваються значні зміни, в тому числі і у правовій сфері. Важливою ознакою та певним маркером демократії в сучасному світі $\epsilon$ належне забезпечення та безперешкодна реалізація доступу до правосуддя. 
Якщо в XIX столітті право на доступ до правосуддя визначалось як формальне право особи на судовий розгляд спору, включаючи лише фізичний доступ особи в будівлю суду та участь у процесі, то останнім часом відбувається модернізація права на доступ до правосуддя. Під впливом сучасних процесів сформувалась повноцінна теоретична концепція, в якій доступність правосуддя визначається як повноцінний комплекс заходів, спрямованих на забезпечення реального доступу громадян до правосуддя. Ця концепція розкриває залежність правосуддя від цілої сукупності умов і необхідності подолання низки бар'єрів.

Сучасна система правосуддя в Україні потребує значних змін, орієнтиром яких повинна слугувати людина, ïï права та свободи. Для досягнення цієї мети важливим $\epsilon$ зменшення бар'єрів щодо доступу до правосуддя.

Слід зазначити, що новітні технології сприяють прогресивним трансформаціям системи правосуддя, оскільки за допомогою електронних технологій доступ до правосуддя значно спрощується. Умовою ефективності застосування сучасних інформаційних технологій у суді виступає належне забезпечення права на доступ до правосуддя. Електронне правосуддя представляється лише певною технологією, що дозволяє на сучасному етапі розвитку суспільства зробити правосуддя більш доступним та ефективним.

Таким чином, на сучасному етапі розвитку право на доступ до правосуддя слід розглядати в якості комплексної, інтегративної соціально-правової категорії, що динамічно розвивається, та орієнтованої на надання i забезпечення системи гарантій для здійснення і захисту прав, свобод і законних інтересів громадян.

\section{Список використаних джерел:}

1. Riesman D. Leisure and Work in Post-Industrial Society / Larrabee E., Meyersohn R. (Eds.). Mass Leisure. Glencoe (III), 1958. P. 363-385. 
2. Белл Д. Грядущее постиндустриальное общество: опыт социального прогнозирования / пер. с англ. В.Л. Иноземцева. Москва : Academia, 1999. 956 с.

3. Drucker P.F. The Age of Discontinuity: Guidelines to our Changing Society. London : Heinemann, 1969. 420 p.

4. Матвєєва Л.Г. Транзитивність у правовій сфері: загальнотеоретичне дослідження : автореф. дис. на здобуття наук. ступеня канд. юрид.наук : 12.00.01. Одеса, 2016. 36 c.

5. Конвенція про захист прав людини та основоположних свобод від 04.11.1950 року. URL: https://zakon.rada.gov.ua/laws/card/995_004 (дата звернення: 03.03.2020).

6. Конституція України : закон України від 28.06.1996 року.№ 254к/96-BP. URL: https://zakon.rada.gov.ua/laws/ card/254к/96-вр (дата звернення: 03.03.2020).

7. Рішення у справі «Голдер проти Великої Британії» від 21.02.1975. URL: http://zakon.rada.gov.ua/laws/show/ 980_086 (дата звернення: 04.03.2020).

8. Рішення у справі «Лучанінова проти України». URL: https://zakon.rada.gov.ua/laws/show/974_788 (дата звернення: 04.03.2020).

9. Рішення у справі «Гоффманн проти Німеччини». URL: http://www.rrpoi.narod.ru/echr/anouther_3/hoffmann.htm (дата звернення: 04.03.2020).

10. Рішення у справі «Аннонні ді Гюссоль та інші проти Франціï». URL: https://www.echr.coe.int/Documents/ Guide_Art_6_UKR.pd (дата звернення: 04.03.2020).

11. Матат Ю. Право на доступ до суду: європейська традиція та проблеми забезпечення в Україні. Національний юридичний журнал: теорія і практика. 2017. № 6. С. 19-23.

12. Верба I.О. Право на доступ до правосуддя як об'єкт наукового аналізу: юридичний аспект. Порівняльноаналітичне право. 2015. № 6. С. 19-22. 
13. Garth Bryant G. and Cappelletti Mauro Access to Justice: The Newest Wave in the Worldwide Movement to Make Rights Effective. Maurer School of Law: Indiana University, 1978. $1142 \mathrm{p}$.

14. Parker C. Just Lawyers: regulation and access to justice. Oxford : Oxford University Press, 1999.278 p.

15. Рішення Конституційного Суду України від 12.04.2012 р. № 9-рп/2012. URL: https://zakon.rada.gov.ua/ laws/show/v009p710-12 (дата звернення: 03.03.2020).

16. Базове дослідження із застосування правосуддя перехідного періоду в Україні : монографія / за заг. ред. А.П. Бущенка, М.М. Гнатовського. Київ : «РУМЕС», 2017. 592 с.

17. Цена реформ / за ред. В.М. Якушика. Дніпро : Середяк Т.К., 2019. 209 с.

18. Кодекс адміністративного судочинства України : Закон України від 06.07.2005 року. № 2747-IV URL: https://zakon.rada.gov.ua/laws/show/2747-15 (дата звернення: 11.04.2020).

19. Кримінальний процесуальний кодекс України : Закон України від 13.04.2012 року. № 4651-VI. URL: https://zakon.rada.gov.ua/laws/card/4651-17 (дата звернення: 03.03.2020).

20. Про реалізацію проекту щодо обміну електронними документами між судом та учасниками судового процесу : наказ Вищого адміністративного суду України від 20.01.2015 № 3. URL: https://zakon.rada.gov.ua/laws/ show/v0003760-15 (дата звернення: 03.03.2020). 
DOI https://doi.org/10.36059/978-966-397-210-7/229-256

Крестовська Н. М., доктор юридичних наук, професор, професор кафедри морського права Національного університету «Одеська морська академія», м. Oдеса

\section{Матвєєва Л. Г.,}

доктор юридичних наук, доцент, завідувач кафедри теорії та філософії права

Одеського державного університету внутрішніх справ, м. Oдеса

\section{ОСОБИСТІ ПРАВА ЛЮДИНИ ПЕРШОГО ПОКОЛІННЯ В НАЦІОНАЛЬНОМУ, РЕГІОНАЛЬНОМУ ТА МІЖНАРОДНОМУ ВИМІРІ}

Анотація. Урозділі особлива увага приділена особистим правам, що належать до першого покоління прав людини, таким як: право на життя; право на вільний розвиток; право на повагу людської гідності; право на свободу і особисту недоторканність у національному, регіональному та міжнародному виміри. Дано визначення особистих прав і свободи людини. Розкрито зміст права на життя та еволюцію його закріплення на універсальному, регіональному та національ-ному рівні. Названі основні обов'язки держави в забезпеченні реалізації права людини на розвиток. Розкрито зміст та права на свободу і особисту недоторканність. Зміст, сутність та характеристики зазначених права людини розглянуто крізь призму практики Європейського суду із прав людини.

\section{Вступ}

Особисті права людини, що належать до першого покоління прав людини, неодноразово ставали об'єктом 
Права людини в Україні та у зарубіжних країнах:

проблеми теорії та нормативно-правової регламентації

дослідження у вітчизняній науці1. Значна увага приділена цьому масиву прав людини у навчальній літературі². Разом із тим невичерпність ідеї прав людини та постійний розвиток практики їх реалізації, захисту та охорони зумовлюють необхідність подальшої розробки цієї проблеми.

Концепція прав першого покоління прав людини початково полягала в тому, що саме так було позначено основні ліберальні цінності, проголошені в ході буржуазних революцій в Європі (особливо під час Великої Французької революції) і становлення США як незалежної

1 Див. Антонович М. Україна в міжнародній системі захисту прав людини: монографія. Київ : Видавничий дім «КM Academia», 2000. 262 с.; Кожан В.В. Особисті права людини: загальнотеоретична характеристика: дис. ... канд. юрид. наук: 12.00 .01 - теорія та історія держави і права; історія політичних і правових учень. Львів, 2016. 229 с.; Пушкіна 0. Особисті права людини в конституційному законодавстві України. Юридична Україна. 2013. № 5. С. 17-24; Рабінович П.М. Основоположні права людини: соціально-антропна сутність, змістова класифікація. Вісник Національної академіі правових наук України. 2013. № 2 (73). С. 10-15; Размєтаєва Ю.С. Права людини як фундаментальна цінність громадянського сус-пільства: монографія. Харків : Финарт, 2013. 196 с.; Шукліна Н.Г. Конституційно-правове регулювання прав і свобод людини і громадянина в Україні (питання теорії і практики) : монографія. Київ : Центр навчальної літератури, 2005. 424 с.

2 Див. Бисага Ю.М., Палінчак М.М., Бєлов Д.М., Данканич М.М. Права людини. Ужгород, 2003. 189 с.; Рабінович П.М., Хавронюк М.I. Права людини і громадянина: навч. посібник. Київ : Атіка, 2004. 464 с.; Права і свободи людини і громадянина в Україні (доктрина Європейського суду з прав людини і Конституційного Суду України) : навчальний посібник / звернення до читачів Голови Конституційного Суду України (VII.2010-VII.2013 роки) Головіна А.C. ; вст. слово і заг. ред. проф. Мартиненка П. Ф., Кампа В. М. Київ : Юрінком Інтер, 2013. 376 с.; Размєтаєва Ю.С. Доктрина та практика захисту прав людини: навчальний посібник. Київ: ФОП Голембовська 0.О., 2018. 364 с.; Проблеми сучасної конституціоналістики: навч. посіб. / за заг. ред. А.Р. Крусян та А.А. Єзерова. Київ: Юрінком Інтер, 2018. 524 с. (Серія «Проблеми сучасної конституціоналістики». Вип. 4: Конституційне гуманітарне право). 
держави (XVII-XIX століття). Такими цінностями було визнано: життя, свободу із засобами набуття і володіння власністю, прагнення до щастя і безпеки (Декларація прав Вірджинії 1776 р.), життя, свободу та прагнення до щастя (Декларація незалежності США 1776 р.); свободу, власність, безпеку, опір гнобленню (французька Декларація людини і громадянина 1789 р.).

Права першого покоління $є$ основою інституту прав людини. За словами К. Веллмана, одне покоління прав людини практично повністю складається 3 «батьків» наступного покоління ${ }^{3}$. У цьому сенсі перше покоління $€$ прабатьком усіх наступних поколінь прав людини.

Поняття «поколінь прав людини», уведене до наукового обігу сорок років тому, з тих пір набуло, крім значення історичного генезису прав людини, властивостей критерію класифікації прав людини: згадуючи перше покоління прав людини, ми маємо на увазі, перш за все, особисті та політичні права. Цей розділ монографії присвячено основоположним особистим правам людини, на забезпечення реалізації яких, по суті, спрямовано усі інші покоління прав людини.

У новітній час ці права знайшли своє відображення в конституціях і законах більшості країн світу, а також в міжнародних документах. Серед них особливе місце займають Всесвітня Декларація прав людини (далі ВДПЛ) і Міжнародний пакт про громадянські і політичні права (далі - МПГП). Механізми захисту прав першого покоління на регіональному рівні представлені Радою Європи та Європейським судом із прав людини, які діють відповідно до Конвенції про захист прав людини та основоположних свобод (далі - КЗПЛ) і Додатковими протоколами до неї. На національному рівні права людини першого покоління, а саме - життя і здоров'я,

3 Wellman C. Solidarity, the Individual and Human Rights. Human Rights Quarterly. 2000. Volume 22, Number 3. P. 641. 
честь і гідність, недоторканність і безпеку визнано властивостями людини, які зумовлюють ії найвищу соціальну цінність (стаття 3 Конституції України).

\section{1. Право на життя: поняття, зміст, нормативне закріплення}

Право на життя - це право на існування людини як біологічної, соціальної та духовної істоти, гарантоване об'єктивним правом.

Змістом права на життя $\epsilon$ такі основні правомочності:

1) право на продовження біологічного існування;

2) право на захист свого життя від неправомірних посягань та від інших загроз життю;

3) право на визначення способів та шляхів існування, які не порушують права інших людей на життя.

На універсальному рівні право на життя вперше було проголошено Всесвітньою Декларацією прав людини [4] 1948 року і підтверджено Міжнародним Пактом про громадянські та політичні права [10] 1966 року (стаття 6), на європейському регіональному рівні - КЗПЛ (стаття 2) [6], на національному рівні - закріплено Конституцією України (стаття 27) [7].

Конституція України закріплює право на життя за допомогою заборони свавільного (незаконного) позбавлення життя. Верховна Рада України скасувала кримінальне покарання у вигляді смертної кари. Отже, ніхто не може бути позбавлений життя навіть за рішенням суду. Другий важливий компонент закріплення права на життя - право людини на самозахист від протиправних посягань на життя і здоров'я.

Але право на життя, всупереч висловлюваній у деяких дослідженнях думці [5], не $\epsilon$ абсолютним. Згідно із частиною 2 статті 2 КЗПЛ позбавлення життя не розглядається як правопорушення 3 боку індивіда або держави, якщо воно є наслідком виключно необхідного застосування сили: 
1) для захисту будь-якої особи від незаконного насильства;

2) для здійснення законного арешту або для запобігання втечі особи, яку законно тримають під вартою;

3) під час вчинення правомірних дій для придушення заворушення або повстання.

Крім того, положення статті 2 Конвенції не поширюються на випадки смерті внаслідок правомірних воєнних дій (частина 2 статті 15 Конвенції).

Отже, захист від незаконного насильства має бути правомірним, достатнім і обгрунтованим. Застосування сили, що спричинило смерть людини, має бути абсолютно необхідним для досягнення однієї з вказаних цілей і має бути пропорційним відвернутій загрозі охоронюваним інтересам. Такі вимоги закріплено в конституціях сучасних держав, кримінальному та кримінально-процесуальному законодавстві.

Праву людини на життя відповідає низка обов'язків держави та інших суб'єктів публічної влади:

заборона свавільного позбавлення життя. Попри рекомендаційну норму МПГП, у багатьох країнах світу досі існує такий вид покарання, як смертна кара. Утім, Пакт вимагає, аби смертні вироки виносилися тільки за найтяжчі злочини відповідно до закону, який діяв під час вчинення злочину і який не суперечить постановам Пакту і Конвенції про запобігання злочинові геноциду і покарання за нього. Смертний вирок не повинен виноситися за злочини, вчинені неповнолітніми, молодшими за вісімнадцять років, і не має виконуватися щодо вагітних жінок.

Ставлення до смертної кари в європейському правовому просторі можна назвати динамічним. Початково КЗПЛ лише обмежувала ії: «Нікого не може бути умисно позбавлено життя інакше ніж на виконання смертного вироку суду, винесеного після визнання його винним у вчиненні злочину, за який закон передбачає таке покарання» (частина 1 статті 2). Протокол № 6 до КЗПЛ (1983) зобов'язав держави-учасниці скасувати смертну 
кару як покарання, зробивши виняток для застосування їі за діяння, вчинені під час війни або невідворотної загрози війни [14]. Нарешті, Протокол № 13 до Конвенції про захист прав людини і основоположних свобод (2002) зобов'язав держави-учасниці Конвенції скасувати смертну кару у всіх випадках [13]. На сьогодні тільки одна країна член Ради Європи - зберігає цей вид покарання, але не застосовує на практиці (Російська Федерація).

Національне законодавство України імплементувало норми, зазначені у вищенаведених міжнародно-правових актах. Стаття 27 Конституції України визначає невід'ємне право кожної людини на життя, право на захист свого життя й життя іншої людини та обов'язок держави захищати життя людини. Рішенням КСУ у справі про смертну кару № 11-рп/99 від 29 грудня 1999 року визначено, що смертну кару як вид покарання не можна вважати винятком із невід'ємного права на життя кожної людини, закріпленого в Конституції України, що знайшло відображення у системі кримінальних покарань, де таке покарання відсутнє [21].

Слід також відмітити, що на сьогодні існує низка проблемних питань, пов'язаних із правом людини на життя, до основних з яких слід віднести: право на штучне переривання вагітності та штучне запліднення, правовий режим здійснення дослідів у галузі ембріології та правовий статус ембріона, питання про правомірність клонування людини, проблеми застосування евтаназії; застосування сили, яка загрожує життю людини з урахуванням вимог абсолютної необхідності та пропорційності.

Держава зобов'язана забезпечити професійну підготовку осіб, що задіяні в охороні правопорядку, аби мінімізувати ризики заподіяння смерті під час виконання ними службових обов'язків..

Критерії абсолютної необхідності пропорційності рельєфно виражено у справах «МакКанн та інші проти Великої Британії» (McCann and others v. the United Kingdom, 
1995) [29] та «Гюлек проти Туреччини» (Gulec v. Turkey, 1998) [39], розглянутих ЄСПЛ.

Фабула першої справи $\epsilon$ такою. Британська розвідка встановила, що Ірландська республіканська армія (IRA) готує терористичний акт на території Гібралтара, причому було встановлено особи ймовірних виконавців. Задля попередження планованого вибуху замінованого автомобілю було вирішено арештувати підозрюваних до вчинення ними теракту. Під час затримання військовослужбовці були уведені в оману жестами підозрюваних, які простягнули руки до внутрішніх кишень/сумочки (одна з підозрюваних була дівчиною). Серією пострілів усі підозрювані були вбиті. При них не було ані зброї, ані вибухівки (правда, вибухівка була в авто, яке підозрювана Фаррелл орендувала на чуже ім'я). Суд встановив, хоча й не одноголосно, порушення статті 2 КЗПЛ. При цьому Суд зазначив, що застосована сила має бути «абсолютно необхідною» для досягнення однієї 3 цілей, викладених у підпунктах (a), (b) i (c) частини 2 статті 2 КЗПЛ, що означає необхідність суворої та ретельної перевірки обставин, за яких застосовується сила, причому необхідно враховувати не тільки дії представників держави, які реально застосовують цю силу, але також і всі супутні обставини, включаючи такі питання, як планування можливих дій і контроль за ними.

По другій справі Судом було встановлено, що під час контртерористичної операції, що проводилася турецькими правоохоронцями 4 березня 1991 р. у місті Іділ, був застрелений 15-річний Ахмед Гюлек, який випадково опинився на місці події. Суд встановив обов'язок держави охороняти право на життя й відповідальність держави за відсутність критичної оцінки обставин, за яких було застосовано зброю, необгрунтоване застосування сили та відсутність об’єктивного розслідування причин смерті Ахмеда Гюлека. 


\section{2. Право на вільний розвиток: поняття, обов'язки держави по його забезпеченню}

Кожна людина має право сама визначати свою долю, ставити перед собою визначені нею самою цілі, обирати засоби для досягнення цих цілей. Саме таким $є$ зміст права на щастя, що відноситься до першого покоління прав людини. У сучасному розумінні право на щастя чи прагнення до щастя набуло характеру права людини на розвиток своєї особистості. Людський розвиток - це процес розширення вибору способу життя для людини. Насамперед це: вести здоровий спосіб життя і жити довго, набувати знань, мати ресурси, аби підтримувати належний життєвий рівень. Сюди ж належать політична, економічна і соціальна свободи, можливість займатися творчою та виробничою діяльністю. Але, зрозуміло, право на вільний розвиток не $є$ безмежним: обираючи свій шлях розвитку, людина не повинна порушувати прав інших людей.

Право на розвиток не зафіксовано у ВДПЛ, але воно набуває все ширшого визнання та підтримки світовим співтовариством. У 1986 року ООН прийняла «Декларацію про право на розвиток» [3], якою було започатковано роз'яснення змісту цього права. Право на розвиток $\epsilon$ невід'ємним правом людини, в силу якого кожна людина і всі народи мають право брати участь у такому економічному, соціальному, культурному та політичному розвитку, за якого можуть бути повністю здійснені всі права людини та основні свободи, а також сприяти йому та користуватися його благами (стаття 1 ).

Принципово важливим $\epsilon$ положення статті 2 Декларації про те, що людина є основним суб'єктом процесу розвитку та має бути активним учасником і бенефіціаром права на розвиток. Право людини на розвиток одночасно означає обов'язок поважати права і свободи інших людей, а також виконувати певні обов'язки перед суспільством. Оскільки лише суспільство спроможне забезпечити вільний 
розвиток людини, люди мають захищати правовий порядок, необхідний для їх розвитку.

Основні обов'язки в забезпеченні реалізації права людини на розвиток Декларація покладає на державу. Держави:

- несуть основну відповідальність за створення національних i міжнародних умов, сприятливих для здійснення права на розвиток;

- мають здійснювати в індивідуальному і колективному порядку заходи, спрямовані на розроблення політики в галузі міжнародного розвитку 3 метою сприяння здійсненню в повному обсязі права на розвиток;

- мають вживати рішучих заходів, спрямованих на ліквідацію масових і грубих порушень прав людини народів i осіб, які стикаються із ситуаціями, що $\epsilon$ результатом апартеїду, всіх форм расизму i расової дискримінації, колоніалізму, іноземного панування i окупації, агресії, іноземного втручання і загроз національному суверенітету, національної єдності і територіальної цілісності, загрози війни і відмови визнати основоположне право народів на самовизначення;

- мають співпрацювати з метою сприяння, заохочення і зміцнення загальної поваги і дотримання всіх прав людини і основних свобод для всіх незалежно від раси, статі, мови або релігії;

- мають сприяти встановленню, підтримці і зміцненню міжнародного миру і безпеки і з цією метою докладати всіх зусиль для досягнення загального і повного роззброєння під ефективним міжнародним контролем, а також для забезпечення використання вивільнюваних в результаті прийняття ефективних заходів щодо роззброєння коштів із метою всебічного розвитку, зокрема країн, що розвиваються;

- на національному рівні мають вживати необхідних заходів для здійснення права на розвиток, забезпечувати рівність можливостей для всіх у тому, що стосується доступу до основних ресурсів, до освіти, охорони здоров'я, харчування, житла, зайнятості, справедливого розподілу 
доходів, забезпечення активної ролі жінок у процесі розвитку, проведення економічних і соціальних реформ.

Надзвичайно важливим $\epsilon$ те, що в Декларації право народів і держав на розвиток сформульоване в нерозривній єдності з їхнім правом на мир, самовизначення, суверенітет над природними, багатствами i ресурсами. Із змісту Декларації випливає весь комплекс основних прав, що становлять «третє покоління» прав людини (права народів). Це такі права, як право народів на мир, на самовизначення, на суверенітет над природними багатствами, на здорове і чисте довкілля, на загальну спадщину людства. Разом із правом на розвиток ці права відкривають перед людством широкі можливості і перспективи для забезпечення індивідуальних і корпоративних прав людини.

Право на розвиток у Конституції України сформульовано в тісному зв'язку з обов'язками людини: «Кожна людина має право на вільний розвиток своєї особистості, якщо при цьому не порушуються права i свободи інших людей, та має обов'язки перед суспільством, в якому забезпечується вільний і всебічний розвиток ії особистості» (стаття 23).

Основне завдання держави полягає в тому, щоби створити найкращі умови і соціально-економічні засади для реалізації цього права, що випливає зі статті 3 Конституції України, за якою права і свободи людини та їх гарантії визначають зміст і спрямованість діяльності держави. Держава, по-перше, має відкрити для кожної людини якомога більше сфер для розвитку власної особистості, по-друге - запобігати порушенням цього права, по-третє - усувати перешкоди для реалізацією людиною свого потенціалу. Право на розвиток тісно пов'язане ыз правами на працю, на освіту та іншими культурними правами. Здійснення державою своїх позитивних обов'язків як гарантій реалізації права людини на розвиток включає створення особливих умов для тих осіб, які з об’єктивних причин самостійно не можуть або 
Права людини в Україні та у зарубіжних країнах:

проблеми теорії та нормативно-правової регламентації

відчувають складнощі у доступі до навчання, до виробничої чи творчої діяльності.

\section{3. Право на повагу людської гідності: зміст та міжнародний, європейський, національний механізми запобігання посягань на гідність людини}

Людська гідність, на переважаючу думку науковців, $є$ витоком усіх прав людини, що випливають із самої природи людини. Людська гідність - це те, що вирізняє людину серед інших явищ оточуючого нас світу У цьому плані зміст цього поняття $\epsilon$ близьким до поняття «людяність», яке П.М. Рабінович визначає як біологічні, психічні, соціальні властивості людини, що відрізняють ії від усіх інших живих істот 4 .

Право на повагу людської гідності - це юридичне закріплення природно-правової категорії людської гідності, яке зумовлює відповідні обов'язки як людини, так і публічної влади, щодо його дотримання та забезпечення. Зміст цього юридичного права розкривається i забезпечується встановленням заборон на дії, що посягають на людську гідність, а саме: катування, жорстоке, нелюдське та таке, що принижує гідність, поводження або покарання, примусові медичні або наукові дослідження на людині без її вільної згоди.

На міжнародному рівні право на повагу людської гідності передбачено статтею 5 ВДПЛ, яка наголошує, що ніхто не повинен зазнавати катувань, або жорстокого, нелюдського, або такого, що принижує його гідність, поводження і покарання, і підтверджено МПГП (стаття 7), на європейському регіональному рівні - КЗПЛ (стаття 3), на національному рівні - закріплено Конституцією України (стаття 28).

4 Див. Грищук О.В. Людська гідність у праві: філософські проблеми. Львів: ЛДУВС, 2007. С. 376; Рабінович П. М. Людяність як об'єкт правового захисту (до 65-річчя завершення Нюрнберзького процесу). Бюлетень Міністерства юстицї України. 2011. № 10. С. 52. 
Зміст понять «катування» розкривається в Конвенції проти катувань та інших жорстоких, нелюдських або таких, що принижують гідність, видів поводження і покарання 1984 р. (на сьогодні учасницями Конвенції є 165 держав). Катування означає будь-яку дію, якою будь-якій особі навмисне заподіюються сильний біль або страждання, фізичне чи моральне, щоб отримати від неї або від третьої особи відомості чи визнання, покарати ії за дії, які вчинила вона або третя особа чи у вчиненні яких вона підозрюється, а також залякати чи примусити ії або третю особу, чи 3 будь-якої причини, що грунтується на дискримінації будьякого виду, коли такий біль або страждання заподіюються державними посадовими особами чи іншими особами, які виступають як офіційні, чи 3 їх підбурювання, чи 3 їх відома, чи за їх мовчазної згоди. У визначені «катування» звертають на себе увагу три елементи:

1) умисний характер заподіяння болю або страждання,

2) мета, 3 якою вони заподіюються (отримання відомостей чи визнання провини, покарання, залякування),

3) особа, що заподіює цей біль або страждання (державна посадова особа).

Цей термін не охоплює біль або страждання, що виникли внаслідок застосування правових санкцій, дій, нерозривно пов'язаних із цими санкціями або випадково викликаних цими санкціями. Наприклад, не $\epsilon$ катуванням застосування фізичної сили чи спеціальних засобів під час затримання особи, яка намагається втекти 3 місця вчиненого нею злочину.

Крім терміна «катування», Конвенція ООН проти катувань не дає визначення інших видів неправового поводження або покарання. Тому ЄСПЛ, розглядаючи скарги про порушення заборони катувань, а також нелюдських або таких, що принижують гідність, видів поводження чи покарання, самостійно розмежував ці поняття.

Дії посадових осіб держави щодо особи, які кваліфікуються як катування, нелюдське поводження чи 
покарання, поводження чи покарання, що принижує гідність, становлять порушення статті 3 Конвенції про захист прав людини та основоположних свобод у разі, якщо вони сягають хоча би мінімального рівня жорстокості. У рішенні у справі «Ірландія проти Великої Британії» (Ireland v. the United Kingdom від 18.01.1978) [38] суд зазначив, що «оцінка мінімального рівня жорстокості має відносний характер; вона залежить від усіх обставин справи, таких як тривалість даного поводження, його фізичні та психічні наслідки, а в деяких випадках - стать, вік, стан здоров'я потерпілого та інші обставини».

ЄСПЛ надає таке розмежування катування та нелюдського чи такого, що принижує гідність, поводження. Катування свідчить про намір надати особливої ганебності умисному нелюдському поводженню, яке спричиняє дуже тяжкі й жорстокі страждання. На додаток до жорстокості поводження ознакою катування $є$ також наявність мети такого поводження, як це визнано в Конвенції ООН проти катувань та інших жорстоких, нелюдських або таких, що принижують гідність, видів поводження і покарання.

Принципи оцінки рівня жорстокості за критеріями ЄСПЛ:

- індивідуальні характеристики потерпілого - його вік, стать, а також його зв'язок із тим, хто завдає йому страждань (зокрема, співвідносність фізичної сили потерпілого 3 фізичною силою особи, яка здійснює затримання чи арешт особи). Так, у рішенні у справі «Корнейкова та Корнейков проти України» [27] від 24.06.2016 Суд визнав порушення статті 3 Конвенції у зв'язку із застосуванням до заявниці в пологовому будинку наручників та у зв'язку з побутовими умовами її тримання у Харківському СІ30;

- межі страждань, зазнавши яких, людина вважається такою, що іï піддали поводженню, забороненому статті 3 КЗПЛ. Нижньою межею страждань уважаються моральні страждання. Так, у рішенні у справі «Yankov v. Bulgaria» [24] від 11.12.2003 Суд зазначив, що примусове гоління голів у 
осіб, які перебувають під вартою, може принижувати їхню людську гідність, породжувати відчуття скривдження й підкорення. Верхньою межею страждань, яких зазнає людина внаслідок порушення статті 3 Конвенції про захист прав людини та основоположних свобод, $\epsilon$ катування. Так, у справі «Aydin v. Turkey» [37] від 25.09.1997 Суд встановив, що побиття, мордування та зґвалтування поліцейськими заявниці, ще й поєднане із психічним насильством, становить порушення статті 3 КЗПЛ і досягає рівня катування.

Поводження чи покарання, що принижують людську гідність, $€$ поводженням, що «спричиняє в потерпілого почуття страху, болісні страждання й почуття неповноцінності, спроможні принизити його гідність i навіть зламати його фізичний і моральний опір» (рішення Суду у справах «Ireland $V$. the United Kingdom» від 18.01.1978).

Нелюдське поводження чи покарання має такі ознаки: умисне застосування фізичного чи психічного насильства щодо особи або невжиття певних заходів, його тривалість (як мінімум впродовж кількох годин поспіль) і як наслідок- тілесні ушкодження або гострі фізичні чи душевні страждання навіть без мети отримання від особи певних відомостей (рішення у справі «Kudla V. Poland» від 26.10.2000). Так, у рішенні у справі «Öcalan v. Turkey» від 12.05.2005 Суд визнав наявність нелюдського поводження 3 огляду на те, що особа незаконно була піддана стражданням від страху бути страченою.

Нелюдське ж покарання може виявлятися у формі одиночного тримання під вартою особи, оскільки «суцільна сенсорна ізоляція, поєднана зі суцільною соціальною ізоляцією, може знищити особистість». Проте лише видалення із співтовариства інших в'язнів через міркування безпеки, дисципліни або захисту не становить нелюдського або такого, що принижує гідність, покарання (рішення у справі «Ramirez Sanchez v. France» від 06.07.2006). 
Важливо, що тягар доведення правомірності дій публічних осіб, які заподіяли шкоду особі під час затримання, арешту чи тримання під вартою, покладається на органи державної влади, адже саме вони мають надати задовільні та переконливі пояснення (рішення у справах «Рібіч проти Австрії» (Ribitsch v. Austria) [20] від 04.12.1995, «Салман проти Туреччини» (Salman v. Turkey) [23], заява № 21986/93, п. 100, ECHR 2000-VII). Органи державної влади повинні вживати всіх заходів для отримання всіх наявних доказів, які мають відношення до події, inter alia, показань очевидців та експертних висновків тощо. Будьякі недоліки в розслідуванні, які підривають можливість встановлення в ході розслідування причин заподіяння ушкоджень або винних осіб, ставлять під сумнів дотримання цього стандарту та вимог оперативності й розумної швидкості, які також передбачаються в цьому контексті (рішення у справі «Савіцький проти України» від 26.10.2012). При тому виправдання в національному суді публічних осіб, як і заподіяли катування чи нелюдського або такого, що принижує гідність, поводження чи покарання, не звільняє державу від відповідальності за статтею 3 Конвенції (рішення у справі Чолак та Філізер проти Туреччини (Colak and Filizer v. Turkey) [40] від 08.01.2004).

Міжнародні механізми попередження катувань i нелюдського і такого, що принижує гідність, поводження або покарання включають:

Конвенцію проти катувань та інших жорстоких, нелюдських або таких, що принижують гідність, видів поводження і покарання, до якої Україна приєдналась 26 січня 1987 р. (далі - Конвенція проти катувань), Факультативний протокол до Конвенції проти катувань, до якого Україна приєдналась 21 липня 2006 р. (далі Протокол до Конвенції проти катувань);

Комітет проти катувань, створений на підставі Конвенції проти катувань, Підкомітет ООН із питань 
Права людини в Україні та у зарубіжних країнах:

проблеми теорії та нормативно-правової регламентації

запобігання катуванням та іншим жорстоким, нелюдським або таким, що принижують людську гідність, видам поводження або покарання, створений на підставі Протоколу до Конвенції проти катувань.

Європейський механізм попередження катувань i нелюдського і такого, що принижує гідність, поводження або покарання включає:

Конвенцію про захист прав людини і основоположних свобод, яка містить імперативну норму про заборону катування нелюдського чи такого, що принижує гідність, поводження або покарання (стаття 3);

Європейську конвенцію про запобігання катуванням чи нелюдському або такому, що принижує гідність, поводженню чи покаранню (ратифікована Україною 24 січня 1997 р.);

Європейський комітет із питань запобігання катуванням чи нелюдському або такому, що принижує гідність, поводженню чи покаранню, який шляхом інспекцій перевіряє поводження 3 позбавленими волі особами з метою посилення, в разі необхідності, захисту таких осіб від катувань чи нелюдського або такого, що принижує їхню гідність, поводження чи покарання;

ЄСПЛ, який розглядає заяви щодо порушення державою статті 3 КЗПЛ.

Абсолютний характер гарантій, передбачених ст. 3 КЗПЛ, означає, що стосовно цього права не може бути жодних винятків і не може існувати жодних підстав для відступу держави від своїх зобов'язань за ст. 3 Конвенції про захист прав людини та основоположних свобод під час війни або іншої надзвичайної ситуації, що загрожує життю нації. Такий характер цієї заборони підкріплюється тим фактом, що дії, які ставляться у провину потерпілому, якими б неприйнятними чи небезпечними вони не були, жодним чином не можуть виправдати будь-яке посягання на гідність, свободу та фізичну недоторканність людини.

Заборона тортур i нелюдських або таких, що принижують гідність, видів поводження чи покарання $\epsilon, \mathrm{y}$ 
світлі рішень ЄСПЛ, однією з фундаментальних цінностей демократичного суспільства, а держава не має право ухилятися від його дотримання навіть у разі війни або іншої загальної небезпеки, яка загрожує життю народу.

Так, у справі «Томасі проти Франції» (Tomasi v. France) [31] від 27.08.1992 ЄСПЛ зазначив, що потреби слідства, а також труднощі в боротьбі зі злочинністю не можуть впливати на обмеження тілесної недоторканності підозрюваного навіть тоді, коли він підозрюється у тероризмі. Розглядаючи в цьому дусі справу «Чахал проти Великої Британії» (Chahal v. United Kingdom) [34] від 15 листопада 1996 року, Європейський суд зазначив, що усвідомлює труднощі, 3 якими в даний час стикаються держави, захищаючи суспільство від насильства терористів. Однак навіть у таких випадках Конвенція про захист прав людини та основоположних свобод забороняє в абсолютному порядку катування, нелюдське або таке, що принижує гідність, поводження чи покарання.

Національний механізм попередження катувань i нелюдського і такого, що принижує гідність, поводження або покарання містить:

- конституційне закріплення поваги до людської гідності, неприпустимості катування, жорстокого, нелюдського та такого, що принижує гідність особи, поводження чи покарання (стаття 28 Конституції України);

- галузеві механізми захисту честі та гідності людини. Цивільно-правовий механізм захисту честі та гідності людини включає право фізичної особи на звернення до суду з позовом про захист гідності та честі, а також ділової репутації (статті 297-299 ЦК України) [33]. Кримінальноправовий механізм запобігання посяганням на людську гідність включає заборону катувань (стаття 127 КК України), а також інститут покарання за злочини проти волі, честі та гідності людини [9];

- Національний превентивний механізм, створений на виконання положень Протоколу до Конвенції проти катувань у форматі «Омбудсмен +», який включає: 
Департамент НПМ як структурний підрозділ Секретаріату Уповноваженого Верховної Ради України з прав людини; регіональних представників Уповноваженого; Експертну раду з питань реалізації національного превентивного механізму; неурядові правозахисні організації, відібрані Уповноваженим для здійснення окремих функцій НПМ; моніторів (індивіди, які беруть участь у моніторингових візитах від громадськості). Головна ідея національного превентивного механізму полягає в запровадженні системи регулярних, незалежних відвідувань будь-якого місця, що перебуває під юрисдикцією та контролем держави, де утримуються чи можуть утримуватися особи, позбавлені волі, за розпорядженням державного органу чи за його вказівкою, або з його відома чи мовчазної згоди.

\section{4. Права на свободу і особисту недоторканність:}

\section{поняття, зміст, нормативне закріплення}

Серед особистих прав, що забезпечують природне існування людини, важливу роль відіграють права на свободу та особисту недоторканність.

Права на свободу та особисту недоторканність - це особисті суб’єктивні права людини, які означають фізичну свободу іï існування, можливість діяти на власний розсуд, не порушуючи при тому прав і свобод інших людей та не посягаючи на правопорядок.

Зміст цих прав полягає в такому:

- заборона будь-якої форми особистої залежності, зокрема, рабства і подібних до нього інститутів (боргова кабала, кріпацтво, насильницьке одруження, фізична передача людини іншій особі у спадок, за плату або без такої);

- заборона свавільного позбавлення волі та насильницького зникнення людини, а також право людини бути звільненою в певний термін у разі затримання, арешту або позбавлення волі, які здійснено правомірно;

- тілесна, статева і психологічна недоторканність, а саме: захищеність від будь-якого протиправного посягання 
на тілесну цілісність та здоров’я людини, її статеву свободу та свободу волі.

Варто зауважити, що права на свободу та особисту недоторканність не $\epsilon$ абсолютними. Міжнародні та національні акти щодо прав людини містять вичерпні переліки обставин, які уможливлюють обмеження прав людини на свободу та особисту недоторканність.

На міжнародному рівні право на свободу і особисту недоторканність проголошено статтею 3 ВДПЛ.

Стаття 9 МПГП деталізує зміст цих прав та правомірне їх обмеження. Нікого не може бути піддано свавільному арешту чи триманню під вартою чи позбавлено волі інакше, як на підставах і відповідно до такої процедури, які встановлено законом. Кожному заарештованому мають бути повідомлено пыд час арешту причини його арешту і в терміновому порядку пред'явлено обвинувачення. Кожна заарештована або затримана за кримінальним обвинуваченням особа в терміновому порядку доставляється до суду, має право на судовий розгляд протягом розумного строку або право на звільнення. При цьому ст. 10 зазначає, що всі особи, позбавлені волі, мають право на гуманне поводження і повагу людської гідності. А ст. 11 виключає можливість позбавлення волі з підстави невиконання особою договірного зобов'язання.

На європейському рівні права на свободу та особисту недоторканність визначено статтею 5 КЗПЛ, яка грунтується на принципі презумпції свободи людини, а саме: нікого не може бути позбавлено свободи, крім таких випадків і відповідно до процедури, встановленої законом, а також визначає виключні випадки позбавлення свободи. Стаття 5 КЗПЛ містить вичерпний перелік випадків правомірного обмеження права на свободу:

«1) законне ув'язнення особи після засудження іiі компетентним судом; 
Права людини в Україні та у зарубіжних країнах:

проблеми теорії та нормативно-правової регламентації

2) законний арешт або затримання особи за невиконання законного припису суду або для забезпечення виконання будь-якого обов'язку, встановленого законом;

3) законний арешт або затримання особи, здійснене 3 метою допровадження їі до компетентного судового органу за наявності обгрунтованої підозри у вчиненні нею правопорушення або якщо обгрунтовано вважається необхідним запобігти вчиненню нею правопорушення чи їі втечі після його вчинення;

4) затримання неповнолітнього на підставі законного рішення 3 метою застосування наглядових заходів виховного характеру або законне затримання неповнолітнього 3 метою допровадження його до компетентного органу;

5) законне затримання осіб для запобігання поширенню інфекційних захворювань, законне затримання психічнохворих, алкоголіків або наркоманів чи бродяг;

6) законний арешт або затримання особи 3 метою запобігання ії̈ недозволеному в'їзду в країну чи особи, щодо якої провадиться процедура депортації або екстрадиції».

ЄСПЛ, з'ясовуючи наявність чи відсутність порушення 3 боку держави статті 5 КЗПЛ, насамперед з'ясовує, чи відповідає Конвенції національний закон, за яким було здійснено обмеження чи позбавлення волі людини i, зокрема, чи відповідають їй загальні принципи закону, зокрема загальний принцип юридичної визначеності. Національний закон, який передбачає можливість позбавлення свободи, має бути доступним, чітко сформульованим і передбачуваним у своєму застосуванні для того, аби особа, отримавши за необхідності юридичну консультацію у справі, могла передбачити з розумним для певних обставин ступенем визначеності, ті наслідки, які може потягнути за собою конкретна дія (рішення у справі «Стіл та інші проти Великої Британії» («Steel and Others v. the United Kingdom») [30] від 23.09.1998).

Затримана чи взята під варту особа має право на перевірку дотримання процесуальних і матеріальних 
вимог, необхідних для законності позбавлення їі свободи (рішення у справі «Ніколова проти Болгарії» «Nikolova v. Bulgaria» [22] від 25.03.1999).

У рішенні у справі «Амуур проти Франції» («Amuur v. France») від 25.06.1996 Суд вказав, що для визначення правомірності позбавлення волі слід враховувати також такі критерії: вид, тривалість, наслідки і умови виконання заходу з позбавлення волі.

У справах щодо України ЄСПЛ визнавав порушення пункту 1 статті 5 КЗПЛ у випадках, коли адміністративний арешт, який формально підпадає під дію пункту 1(а) статті 5, використовувався для забезпечення перебування особи під вартою для інших цілей; або коли не існувало жодних законодавчих положень (у КПК чи інших нормативно-правових актах), які б передбачали, навіть шляхом посилання, процедуру щодо тримання особи під вартою 3 метою екстрадиції або застосування інших міжнародно-правових заходів правової допомоги у кримінальних справах; коли тримання особи під вартою не переслідувало жодну мету, зазначену в пункті 1 статті 5 Конвенції, i, отже, порушило вимоги цієї статті (наприклад, протягом періоду, коли щодо особи не було скасовано рішення про надання статусу біженця, а національне законодавство забороняло вислання біженців із території України, або коли затримання неповнолітніх заявників не підпадає під виняток, передбачений пунктом 1(d) статті 5 за відсутності підстав вважати, що на цю справу поширюються будь-які інші винятки, передбачені статтею 5 Конвенції). У низці справ щодо України було констатовано порушення пункту 1 (f) статті 5 Конвенції у зв'язку з тим, що національне законодавство не передбачає процедури, достатньо доступної, чітко сформульованої і передбачуваної у своєму застосуванні - такої, яка давала б змогу уникнути ризику свавільного тримання під вартою в очікуванні на екстрадицію [32].

Рішення ЄСПЛ у справі «Будан проти України» [25] від 14.01.2016 року звертає увагу на необхідність врахування 
віку затриманої за підозрою у вчиненні злочину особи. Зокрема, було констатовано порушення пункту 1 статті 5 КЗПЛ через те, що органами влади не було розглянуто можливість передачі неповнолітнього затриманого під нагляд батьків.

Зі змісту права на свободу та особисту недоторканність випливає низка обов'язків держави в разі втручання ії органів у свободу та особисту недоторканність осіб, зокрема: знати про місце знаходження особи, якщо вона була взята під варту органами влади; надати інформацію стосовно місця знаходження цієї особи; вжити ефективних заходів для гарантованого запобігання ризику зникнення людей.

Для правильного розуміння цих обов'язків держави варто звернутись до кількох рішень Європейського суду з прав людини. Зокрема, це рішення у справі «Кіпр проти Туреччини» («Cyprus v. Turkey») [26] від 10.05.2001 p. Обставини справи пов'язані 3 фактичною окупацією турецькими військовими північної частини Республіки Кіпр (1974) та проголошенням Турецької Республіки Північний Кіпр (1983, незалежність ТРПК не визнана жодною країною, крім Туреччини). Кіпр як державазаявниця зазначала, що саме Туреччина несе відповідальність за порушення прав людини на окупованій нею території Кіпру. Туреччина заперечувала свою відповідальність за порушення прав людини у Північному Кіпрі, стверджуючи, що ТРПК була незалежною державою, на яку не поширюється юрисдикція Туреччини. ЄС ыз прав людини постановив, що факти, стосовно яких було подано скарги, підпадають під юрисдикцію Туреччини. Зокрема, Туреччина несе відповідальність за нездатність власних органів влади провести ефективне розслідування щодо місцезнаходження і долі зниклих безвісти греків-кіпріотів за обставин, що загрожують життю.

Важливим $\epsilon$ процесуальний аспект цих обов'язків держави. У рішенні по справі «Курт проти Туреччини» («Kurt v. Turkey» від 25.05.1998) [28] суд встановив, що 
відсутність документальної фіксації таких відомостей, як дата, час і місце затримання особи, їі ім'я, підстави для затримання та ім'я особи, яка здійснює затримання, має вважатися таким, що суперечить вимозі законності і самій меті ст. 5 КЗПЛ.

На національному рівні право на свободу та особисту недоторканність закріплено статтею 29 Конституції України, в якій встановлено критерії правомірності обмеження свободи та недоторканності особи:

1) підстави та порядок тримання під вартою встановлюються законом;

2) нагальна необхідність запобігти злочинові чи його перепинити;

3) невідкладне повідомлення особі про мотиви арешту чи затримання, роз'яснення його/ії прав та надання можливості з моменту затримання захищати себе особисто та користуватися правничою допомогою захисника;

4) тимчасовий характер тримання особи під вартою. Обгрунтованість цього запобіжного заходу протягом сімдесяти двох годин має бути перевірена судом;

5) вмотивоване рішення суду про тримання під вартою;

6) негайне звільнення з-під варти, якщо протягом сімдесяти двох годин із моменту затримання особі не вручено вмотивованого рішення суду.

Законність затримання та застосування запобіжних заходів щодо підозрюваних, обвинувачених осіб конкретизується положеннями Глави 18 «Запобіжні заходи, затримання особи» КПК України.

\section{Висновки}

Права людини, що сформульовані в часи становлення першого їх покоління, полягають у праві на життя, на свободу, в тому числі й на право захищати її від посягань 3 боку держави, у прагненні до щастя, на сучасному етапі розвитку людства набули характеру особистих прав людини, якими $\epsilon$ закріплені об'єктивним правом 
Права людини в Україні та у зарубіжних країнах:

проблеми теорії та нормативно-правової регламентації

можливості фізичного існування, соціального буття i духовного розвитку індивіда. Вони $\epsilon$ виразом індивідуальності, автономії та свободи людини, і в цьому сенсі - «бар'єром» від посягань на індивіда з боку інших людей, суспільства та держави.

Особисті права людини традиційно розглядаються в контексті природно-правової теорії, адже такі права $\epsilon$ вираженням природи людини, що не залежать від формально-юридичного їх закріплення. До особистих прав людини, зважаючи на їхню природність, основоположність та невід'ємність, належать: право на життя; право на вільний розвиток; право на повагу до людської гідності; право на свободу та особисту недоторканність. Похідними від цих основоположних прав першого покоління виступають: право на недоторканність житла; право на таємницю листування, телефонних розмов, телеграфної та іншої кореспонденції; право на свободу пересування та вільний вибір місця проживання; право на свободу думки і слова, на вільне вираження своїх поглядів і переконань; право на свободу світогляду і віросповідання.

Особисті права людини, на відміну від усіх інших прав, можуть реалізовуватися людиною без будь-якого стороннього втручання чи допомоги і тому в системі відносин між індивідом та державою/публічною владою носять негативний характер, оскільки вимагають невтручання держави у сферу їх приватного життя. Для держави вони $є$ обмеженням, на що звертав увагу Адемар Есмен: держава має утримуватися від втручання в певні сфери, надаючи певний простір особистій діяльності [36]. Утім, реалізація людиною цих прав вимагає й виконання позитивних обов'язків із боку держави та інших агентів публічної влади, що закріплено на національному, регіональному європейському та міжнародному рівнях. Саме ці обов'язки держави/публічної влади зумовлюють створення та функціонування організаційно-правових механізмів захисту прав людини, серед яких чільне місце 
належить інституту омбудсмана, Європейському суду із прав людини, правозахисним структурам $00 \mathrm{H}$.

\section{Список використаних джерел:}

1. Антонович М. Україна в міжнародній системі захисту прав людини: монографія. Київ : Видавничий дім «KM Academia», 2000. 262 c.

2. Бисага Ю.М., Палінчак М.М., Бєлов Д.М., Данканич М.М. Права людини. Ужгород, 2003. 189 с.

3. Декларация о праве на развитие: Принята резолюцией 41/128 Генеральной Ассамблеи от 4 декабря 1986 г. URL: https://zakon.rada.gov.ua/laws/show/995_301.

4. Загальна декларація прав людини від 10 грудня 1948 p. URL: https://zakon.rada.gov.ua/laws/show/995_015.

5. Кожан В.В. Особисті права людини: загальнотеоретична характеристика : дис. ... канд. юрид. наук : спец. 12.00.01. Львів, 2016. 229 с.

6. Конвенція про захист прав людини і основоположних свобод від 11 листопада 1950 p. URL: https://zakon.rada.gov.ua/laws/show/995_004.

7. Конституція України: Прийнята на V сесії Верховної Ради України 28 червня 1996 р. Відомості Верховної Ради України. 1996. № 30. Ст. 141. URL: http://zakon2.rada.gov.ua/ laws/show/254\%D0\%BA/96-\%D0\%B2\%D1\%80.

8. Конституція України : Прийнята на V сесії Верховної Ради України 28 червня 1996 р.// Відомості Верховної Ради України. 1996. № 30. Ст. 141. URL: http://zakon2.rada.gov.ua/ laws/show/254\%D0\%BA/96-\%D0\%B2\%D1\%80.

9. Кримінальний кодекс України : Закон України від 5 квітня 2001 p. (зі змінами і доповненнями) URL: http://portal.rada.gov.ua.

10. Міжнародний пакт про громадянські і політичні права. URL: https://zakon.rada.gov.ua/laws/show/995_043.

11. Права і свободи людини і громадянина в Україні (доктрина Європейського суду 3 прав людини i Конституційного Суду України) : навчальний посібник. Київ : Юрінком Інтер, 2013. 376 с. 
12. Проблеми сучасної конституціоналістики: навч. посіб. / за заг. ред. А.Р. Крусян та А.А. Єзерова. Вип. 4: Конституційне гуманітарне право. Київ : Юрінком Інтер, 2018. 524 c.

13. Протокол № 13 до Конвенції про захист прав людини i основоположних свобод, який стосується скасування смертної кари за всіх обставин. URL: https://zakon.rada.gov.ua/laws/show/994_180.

14. Протокол № 6 до Конвенції про захист прав людини і основоположних свобод, який стосується скасування смертної кари. URL: https://zakon.rada.gov.ua/laws/show/ 994_802.

15. Пушкіна 0. Особисті права людини в конституційному законодавстві України. Юридична Украӥна. 2013. № 5. С. 17-24.

16. Рабінович П.М. Основоположні права людини: соціально-антропна сутність, змістова класифікація. Вісник Національної академії правових наук Украӥни. 2013. № 2(73). C. $10-15$.

17. Рабінович П.М., Хавронюк М.I. Права людини i громадянина: навч. посібник. Київ : Атіка, 2004. 464 с.

18. Размєтаєва Ю.С. Права людини як фундаментальна цінність громадянського суспільства : монографія. Харків : Финарт, 2013. 196 с.

19. Размєтаєва Ю.С. Доктрина та практика захисту прав людини: навчальний посібник. Київ : ФОП Голембовська 0.0., 2018. 364 c.

20. Рибич (Ribitsch) против Австрии. Решение ЕСПЧ от 4 декабря 1995 г. URL: http://www.echr.ru/documents/ doc/2461491/2461491.htm.

21. Рішення КСУ у справі за конституційним поданням 51 народного депутата України щодо відповідності Конституції України (конституційності) положень статей $24,58,59,60$, 93, 190-1 Кримінального кодексу України в частині, що передбачає смертну кару як вид 
покарання (справа про смертну кару). URL: https://zakon.rada.gov.ua/laws/show/v011p710-99.

22. Рішення у справі «Ніколова проти Болгарії» від 25 березня 1999 p. URL: https://zakon.rada.gov.ua/laws/show/ 980_404.

23. Рішення у справі «Салман проти Туреччини» від 04 грудня 1995 p. URL: http://search.ligazakon.ua/l_doc2.nsf/ link1/S02538.html.

24. Рішення у справі «Янков проти Болгарії» від 11 грудня 2003 p. URL: https://zakon.rada.gov.ua/laws/ show/980_213.

25. Справа «Будан проти України» від 14 січня 2016 р. URL: https://zakon.rada.gov.ua/laws/show/974_b06.

26. Справа «Кіпр проти Туреччини» (Case of Cyprus v. Turkey) від 10 травня 2001 p. URL: https://rm.coe.int/ $16806 \mathrm{~b} 5964$.

27. Справа «Корнейкова та Корнейков проти України» від 24 червня 2016 p.. URL: https://zakon.rada.gov.ua/ laws/show/974_b56.

28. Справа «Курт проти Туреччини» («Kurt v. Turkey») від 25 травня 1998 р. URL: http://europeancourt.ru/uploads/ ECHR_Kurt_v_Turkey_25_05_1998.pdf.

29. Справа «МакКанн та інші проти Сполученого Королівства». Рішення ЄСПЛ від 27 вересня 1995 року. C. 204-296. URL: http://aau.edu.ua/static/pdf/art2_judg1.pdf.

30. Справа «Стіл та інші проти Сполученого Королівства» (Case of Steel and others v. the United Kingdom) від 23 вересня 1998 p. URL: https://zakon.rada.gov.ua/laws/ show/980_106.

31. Томази (Tomasi) против Франции. Решение ЕСПЧ от 27 августа 1992 г. URL: http://europeancourt.ru/uploads/ ECHR_Tomasi_v_France_27_08_1992.pdf.

32. Фулей Т. Проблеми забезпечення права особи на свободу та особисту недоторканність: коментар до справи «Харченко проти України». Судова практика. 2012. № 1(115). C. 126-129. 
33. Цивільний кодекс України : Закон України від 16 січня 2003 p. URL: http://portal.rada.gov.ua.

34. Чахал против Соединенного Королевства. Решение ЕСПЧ от 15 ноября 1996 г. URL: https://precedent.in.ua/ 2016/04/08/chahal-protyv-soedynennogo-korolevst/.

35. Шукліна Н.Г. Конституційно-правове регулювання прав і свобод людини і громадянина в Україні (питання теорії і практики) : монографія. Київ : Центр навчальної літератури, 2005. 424 с.

36. Эсмен А. Общие основания конституционного права: пер. с 4-го франц. изд. под ред. Н.О. Бер. 2-е изд. Санкт-Петербург : Тип. О.Н. Попова, 1909. 461 с.

37. Case of Aydin v. Turkey. 25 Septemder 1997, European Court of Human Rights. The International Journal of Human Rights. Volume1, 1997. Issue 4. P. 86-89. URL: https://www.tandfonline.com/doi/abs/10.1080/1364298970 8406700 .

38. Case of Ireland v. the United Kingdom. Judgment 18 January 1978. URL: https://www.law.umich.edu/ facultyhome/drwcasebook/Documents/Documents/Republic \%20of\%20Ireland\%20v.\%20United\%20Kingdom.pdf.

39. Case Gulec v. Turkey. 27th July 1998, European Court of Human Rights. The International Journal of Human Rights. Volume 3, 1999. Issue 1. P. 110-112. URL: https://www.tandfonline.com/doi/abs/10.1080/1364298990 8406791? journalCode=fjhr20.

40. Case Colak and Filizer v. Turkey. 08.01. 2004. URL: https://www.hrr-strafrecht.de/hrr/egmr/96/32578-96.php3.

41. Wellman C. Solidarity, the Individual and Human Rights. Human Rights Quarterly. 2000. Volume 22, Number 3. P. 639-657. 
DOI https://doi.org/10.36059/978-966-397-210-7/257-282

\author{
Лотюк О. C., \\ доктор юридичних наук, професор, \\ професор кафедри конституційного права \\ Київського національного університету \\ імені Тараса Шевченка, \\ м. Київ
}

Митник О. В.,

аспірантка кафедри конституційного права

Київського національного університету

імені Тараса Шевченка,

керівник експертної групи з прав людини

Директорату стратегічного планування

та європейської інтеграції

Міністерства юстиції України,

м. Київ

\title{
ГЕНЕЗИС МЕХАНІЗМУ СУДОВОГО ЗАХИСТУ КОНСТИТУЦІЙНИХ ПРАВ ЛЮДИНИ
}

Анотація. Судовий захист конституційних прав людини розглядається як одна з моделей захисту конституційних прав людини через призму виконання державою своїх універсальних зобов'язань щодо прав людини.

у дослідженні здійснено аналіз історичного розвитку ідеї прав людини та охарактеризовано різні підходи щодо їх тлумачення та типологізації. Наголошується, що процес утвердження прав людини супроводжується зміною парадигми відносин людина - держава, що і визначатиме в подальшому розвиток системи судового захисту конституційних прав людини. Виникнення національних режимів захисту прав людини пов'язується з виникненням перших декларацій прав людини (кінець $18 \mathrm{~cm}$.), досліджуються 
Права людини в Україні та у зарубіжних країнах:

проблеми теорії та нормативно-правової регламентації

легітимні обов'язки держави щодо прав людини: позитивні (утверджувати, захищати права людини) та негативні (утримуватися від порушень прав людини). Як результат прийняття ключових міжнародних документів у сфері прав людини (міжнародні стандарти прав людини), досліджується процес універсалізації зобов'язань держав щодо захисту прав людини та створення міжнародних і регіональних режимів захисту прав людини. Таким чином, автори доходять висновку про виникнення, поряд із національними, універсальних зобов'язань держави щодо прав людини: не порушувати, захищати та сприяти реалізації прав і свобод. Саме 3 обов'язком держави захищати права людини пов'язується існування судового механізму захисту конституційних прав $i$ свобод.

Авторами дослідження описано чотири етапи розвитку механізму судового захисту конституційних прав людини через призму генезису та становлення ідеї прав людини. 3 огляду на множинну правову природу судового захисту зазначену категорію розглянуто як основоположне право; гарантію основоположних прав; ефективний засіб захисту; механізм захисту прав людини. Надано авторське визначення механізму судового захисту конституційних прав людини та виокремлено його основні ознаки. Автори також окреслили власне бачення перспективних напрямів дослідження механізму судового захисту конституційних прав з огляду на його подальшу трансформацію у зв'язку з інтеграційними та глобалізаційними процесами, а також у контексті цифровізації доступу до правосуддя.

\section{Вступ}

Із часу прийняття ключових міжнародних документів у сфері прав людини проблема реалізації правозахисної функції держави не втрачає своєї актуальності. Питання парадигми відносин «людина - держава» та ролі держави у захисті конституційних прав людини тривалий час $\epsilon$ предметом дискусії філософів, правників, теоретиків та практиків. 
Відтак тематика прав людини, функціонування режимів ïx захисту достатньо широко досліджена у працях як українських науковців (П. Рабіновича, С. Шевчука, С. Головатого, О. Марцеляка, М. Савчина, О. Васильченко, М. Орзіха, М. Козюбри, В. Буткевича, В. Кампа, В. Шишкіна, Н. Карпачової, Ю. Тодики, М. Гнатовського та ін.), так i представників іноземних правничих шкіл: Т. Пейна, Б. Таманаги, П. Гаудера, Л. Свендсена, Ш. Госепата, Г. Ломанна, Р. Дворкіна, Г. Харта, О. Гьоффе, Л. Фуллера, М. Манукяна та ін. Філософія та сутність судового захисту знайшли свої відображення у роботах В. Бігуна, Б. Малишева, С. Шевчука, О. Лемак. Водночас витоки становлення ідеї судового захисту прав людини містяться у класичних роботах філософсько-правової та політичної думки, зокрема працях Аристотеля, Цицерона, Платона, Ж.-Ж. Руссо, I. Канта, Т. Гоббса, Ш. Монтеск'є, Г. Гроція, Т. Джеферсона та ін.

Хоча прийнято вважати, що судовий захист $є$ однією 3 найефективніших моделей захисту прав людини, це не убезпечує від фактів порушень основоположного права людини на доступ до суду. Зокрема, як свідчить статистика рішень Європейського суду з прав людини (далі - ЄСПЛ), близько 40\% порушень, констатованих Судом, стосуються статті 6 Європейської конвенції із прав людини (далі ЄКПЛ, Конвенція), а саме справедливого судового розгляду (16,86\%) та тривалості процедур $(21,41 \%)$ [33]. Це ілюструє необхідність пошуку більш ефективних механізмів судового захисту конституційних прав і свобод людини та вдосконалення тих механізмів, які існують, відповідно до загальновизнаних норм і стандартів.

Водночас задля пошуку найбільш оптимальних шляхів вдосконалення механізму судового захисту конституційних прав людини, на наше переконання, важливо дослідити генезис та правову природу такого механізму та надати відповідь на засадничі питання щодо сутності судового захисту прав людини та його втілення в національних, регіональних та міжнародному режимах прав людини, трансформації ролі суду в загальній системі 
Права людини в Україні та у зарубіжних країнах:

проблеми теорії та нормативно-правової регламентації

захисту прав людини. У цьому контексті важливо дослідити процес становлення концепції судового захисту конституційних прав людини через призму виконання державою зобов'язань щодо прав людини, здійснити періодизацію розвитку механізму судового захисту конституційних прав людини.

\section{1. Розвиток ідеї прав людини та становлення}

\section{концепції захисту конституційних прав людини}

Починаючи 3 часів античності філософи, юристи, правозахисники намагаються зрозуміти сутність прав людини, віднайти найкращі інструменти для їх втілення. Перефразувавши думку I. Канта, який зауважує: «Питання про те, що таке право, становить для юриста таку ж складність, як і для логіки питання, що таке істина» [9, с. 10], можна стверджувати те ж саме і про права людини. Водночас необхідність єдиного, універсального тлумачення прав людини не $\epsilon$ проблемою суто теоретичною чи філософською, а має конкретне практичне значення. Так, від розуміння вихідних понять залежить, які права захищати і хто є суб'єктом прав, чи існують поряд із класичними індивідуальними правами людини також «колективні» права людини, як визначається носій прав i хто $\epsilon$ адресатом відповідних обов'язків [27, с. 18].

Намагаючись здійснити певне розмежування, Отфрид Гьоффе надає таку типологію прав людини: «Там, де ми говоримо про суб'єктивні права, маючи на увазі громадянина, що належить до певного правового та державного устрою, ми говоримо про основні права. Проте інститут права (суб'єктивного) має глибшу основу: людина висуває вимоги на «вроджені» (природні) права тільки тому, що вона людина, а це означає - незалежно від інституту держави. Отже, під правами людини слід розуміти права, що належать людині, як людині, тоді як під основними правами - елементарні права кожного громадянина держави» [12, с. 34]. У цілому підтримуючи вищезгадану ідею, зазначимо, що дослідження генезису 
становлення ідеї прав людини дає змогу чітко прослідкувати трансформацію прав людини із природних (основоположних, універсальних) у конституційні права.

Витоки універсалізму прав людини можна простежити ще в мислителів античності. Так, встановлюючи різницю між природньою та соціальною справедливістю, Аристотель пише, що природня справедливість не залежить від того, погоджуються з нею чи ні, має однакову цінність всюди, долає кордони соціальних і політичних систем. Ж.-Ж. Руссо, відстоюючи принцип невідчужуваності прав людини у державі, зазначає, що «людина народжується вільною, але всюди вона в кайданах» [5, с. 315]. У розумінні Локка всі люди народжуються вільними й рівноправними, вони мають певні права, які дійсні незалежно від позитивних законів у різних суспільствах [28, с. 220].

У «Декларації незалежності 1776 року», одним із ідеологів якої був Т.Джефферсон, зазначено: всі люди створені рівними, наділеними Творцем визначеними невід'ємними правами, серед яких право на життя, свободу та щастя; для забезпечення цих прав серед людей існують уряди, які здійснюють свою владу зі згоди тих, ким вони управляють; якщо форма правління стає згубною, народ має право змінити або відмінити ії, і встановити владу в такій формі, яка б найкраще захищала б його безпеку i добробут. Трохи пізніше, в 1787 році, була прийнята Конституція США, перші 10 поправок до якої («Білль про права») містили положення, які поєднували принципи Великої хартії вольностей та ідеї філософів-просвітників [9, с. 18].

Велика французька революція 1789 року також увібрала в себе ідею невідчужуваних природних прав людини та досвід американських батьків-засновників. Так, Декларація містила цікаві 3 точки зору прав людини положення: «Люди народжуються і залишаються вільними і рівними у правах; суспільні відмінності можуть ґрунтуватися лише на основі загальної користі. Метою кожного політичного 
об'єднання є збереження природних і невід'ємних прав людини; цими правами є свобода, власність, безпека і опір гніту. Усяке суспільство, в якому не забезпечуються гарантії прав або не проведено розподілу влад, не має конституції взагалі» [30].

У зв'язку із цим Отфрид Гьоффе звертає увагу на те, що перші декларації прав людини (напр. французька Декларація прав людини і громадянина 1789 року) формулюють «переддержавні права» (природні права прим. автора), тобто такі, що $є$ дійсними до існування держави. Лише потім держава як втілення суспільної влади отримує легітимацію щодо прав людини (курсив - наш)1. Перед державою стоїть завдання сприяти реалізації, або ж гарантувати їх [12, с. 34].

Так виникають національні режими захисту прав людини, а природні права отримують визнання державами та формальне закріплення у конституціях, тобто стають конституційними. Цей процес супроводжується зміною парадигми відносин людина - держава, що і визначатиме в подальшому розвиток системи захисту прав людини.

Цілком доречно в цьому випадку говорити про виникнення легітимних обов'язків держави щодо прав людини: позитивних (утверджувати, захищати) та негативних (утримуватися від порушень). Ці зобов'язання мали свої особливості, що полягали, по-перше, в існуванні монополії держави в питаннях захисту прав своїх громадян. По-друге, вже 3 часу прийняття перших декларацій прав людини дуже чітко прослідковується подвійна природа зобов'язань держави щодо людини: 3 одного боку, держава - це суб'єкт, який через систему відповідних органів зобов'язаний гарантувати, захищати права, з іншого боку, держава є таким самим суб'єктом, на який поширюється обов'язок утримуватися від порушень прав (що є запереченням принципу "nemo debet esse iudex

1 Очевидно, в цьому випадку йде мова про «державні», конституційні права. 
Права людини в Україні та у зарубіжних країнах:

проблеми теорії та нормативно-правової регламентації

in propria causa"). Для того аби принцип «ніхто не може бути суддею у власній справі» було дотримано в питаннях, коли порушником виступає власне держава, зі створенням міжнародного режиму захисту прав людини концепція правосуддя набула нового змісту.

Універсалізація зобов'язань держав щодо захисту прав людини. Питання про те, яким чином найкраще реалізувати правозахисну, правоутверджувальну i правозабезпечувальну функції держави, набуло нового значення після прийняття ключових міжнародних документів у сфері прав людини (т.зв. міжнародні стандарти прав людини) $)^{2}$. Існування цих стандартів заклали підвалини функціонування міжнародного режиму захисту прав людини.

Поступово, окрім міжнародних, утворюються регіональні режими захисту прав людини ${ }^{3}$ (Європейський, Міжамериканський, Африканський, Азійський тощо). Ці режими також характеризуються наявністю певних стандартів із прав людини (Європейська конвенція з прав людини, Хартія Основних прав $€ C$, Міжамериканська конвенція 3 прав людини, Африканська хартія прав людини та народів, Декларація прав людини Асоціації держав Південно-Східної Азії тощо).

Для того аби імплементувати ці режими (міжнародний та регіональні правові режими - прим. авторів), в останні десятиліття були створені різні міжнародні та регіональні трибунали, зокрема Міжнародний суд (Світовий суд),

2 Див. Статут Організації Об’єднаних Націй, Загальна декларація прав людини, Міжнародний пакт про громадянські і політичні права, Міжнародний пакт про соціальні, економічні та культурні права, Конвенція про захист прав людини і основоположних свобод.

3 Детальніше про регіональні режими захисту прав людини див. Шуміло І.А. Міжнародна система захисту прав людини : навчальний посібник / І. А. Шуміло. Київ : ФОП Голембовська О.О., 2018. 168 с. Манукян В.И. Международная защита прав человека: право, прецеденты, комментарии: Научно-практическое пособие. Київ : Истина, 2010. 480 с. 
Права людини в Україні та у зарубіжних країнах:

проблеми теорії та нормативно-правової регламентації

Міжнародний трибунал із морського права, Суд $Є C$, Центральноамериканський суд, Європейський суд із прав людини, Міжамериканський суд із прав людини, Трибунали військових злочинів колишньої Югославії та Руанди, Міжнародний кримінальний суд та інші [29, с. 127].

Згодом положення Загальної декларації прав людини та інших міжнародних стандартів органічно знайшли своє відображення в конституції майже кожної держави, і саме держава відтоді визнається відповідальною за ефективну реалізацію функції захисту прав людини. Так, у 1993 році на Світовій конференції із прав людини було прийнято Віденську декларацію та програму дій, в якій зазначено: «Усі права людини $є$ універсальними, неподільними та взаємозалежними та взаємопов'язаними... Незважаючи на значення національних та регіональних особливостей та різних історичних, культурних та релігійних обставин, обов'язком держав, незалежно від їх політичної, економічної та культурної систем, $\epsilon$ сприяти і захищати усі права людини та основоположні свободи... Права людини та основоположні свободи належать усім людям від народження; їх захист та просування - це найперша відповідальність урядів» (курсив - авторів) [34].

Ця теза знайшла відображення i в практиці Конституційного суду України. Зокрема, в одному з рішень Конституційний Суд України зазначив, що держава, виконуючи свій головний обов'язок - утвердження i забезпечення прав і свобод людини (частина друга статті 3 Конституції України) - повинна не тільки утримуватися від порушень чи непропорційних обмежень прав і свобод людини, але й вживати належних заходів для забезпечення можливості їх повної реалізації кожним, хто перебуває під ії юрисдикцією. Із цією метою законодавець та інші органи публічної влади мають забезпечувати ефективне правове регулювання, яке відповідає конституційним нормам i принципам, та створювати механізми, необхідні для задоволення потреб та інтересів людини (абзац перший пункту 3 мотивувальної частини ) [17]. 
Таким чином, поряд із національними виникають універсальні зобов'язання держави щодо прав людини. Характер таких зобов'язань можливо дослідити через аналіз положень Міжнародного пакту про громадянські та політичні права (далі - Міжнародний пакт).

Перше зобов'язання держави - поважати i забезпечувати всім, хто перебуває в межах їі території та знаходиться під їі юрисдикцією, права, визнані в цьому Пакті, без будь-якої різниці щодо раси, кольору шкіри, статі, мови, релігії, політичних чи інших переконань, національного чи соціального походження, майнового стану, народження чи іншої обставини [10]. Ці дві складові частини вищезгаданого зобов'язання - поважати i забезпечувати - можна розтлумачити таким чином.

Держава виконує зобов'язання «поважати» визнані права, не порушуючи їх. Кожного разу, коли державний орган, службова особа чи державна організація порушує право, виникає невиконання обов'язку поважати це право. Порушення права, яке було здійснено не безпосередньо державою (наприклад, тому, що це вчинок приватної особи або тому, що відповідальна особа не була визначена), також може визнати неспроможність держави «поважати» право, проте не через сам факт порушення, а через відсутність належних заходів для запобігання порушенню чи реагування на нього [32, с. 46].

«Забезпечувати» означає обов'язок держави організувати урядовий апарат i, як правило, всі структури, за допомогою яких реалізується державна влада, таким чином, щоб вільне та повне використання цих прав було забезпечено. Тобто повинні існувати механізми, за допомогою яких держава може запобігти, розслідувати та покарати будь-яке порушення права i, якщо це можливо, відновити порушене право (курсив - авторів) та надати таку компенсацію, яка може бути гарантована за будь-яку шкоду, спричинену порушенням. Держава також несе юридичний обов'язок запобігати порушенню прав людини та використовувати засоби, які вона має, для проведення 
грунтовного розслідування порушень, вчинених у межах іiі юрисдикції, для виявлення порушників, призначення відповідного покарання та забезпечення компенсації потерпілій особі [32, с. 46-47].

Друге зобов'язання держави за Міжнародним пактом відповідно до своїх конституційних процедур вжити необхідних заходів для реалізації визнаних прав.

Третє зобов'язання - забезпечити ефбективний засіб захисту. Суть цього зобов'язання полягає в тому, щоб будь-яка особа, права чи свободи якої порушені, мала ефективний засіб захисту, незважаючи на те, що порушення було вчинено особами, які діють від імені держави; гарантувати, що будь-яка особа, яка вимагає такий засіб захисту, має своє право на це визначене компетентними судовими (курсив - авторів), адміністративними чи законодавчими органами чи правовою системою, а також розвивати можливості судового перегляду; та забезпечити, щоб компетентні органи надавали такі гарантовані засоби правового захисту [10]. Аналогічні зобов'язання беруть на себе держави, які $\epsilon$ сторонами ЄКПЛ (стаття 13).

Розглядаючи питання компенсацій за порушення державою прав людини, М. Гнатовський виокремлює також зобов'язання забезпечити відповідність національного законодавства міжнародно-правовим зобов'язанням (включення міжнародних норм у галузі прав людини до їхнього національного законодавства або їх застосування іншим чином у рамках національної правової системи; вжиття необхідних ефективних законодавчих i адміністративних процедур та інших відповідних заходів, що забезпечують на справедливих умовах ефективний і негайний доступ до правосуддя; забезпечення адекватних, ефективних, швидких i належних засобів правового захисту, включно із відшкодуванням тощо) [4, с. 7].

Загалом же виокремлюють 3 ключові зобов'язання держав щодо прав людини: не порушувати, захищати 
та сприяти реалізації прав і свобод. Саме з обов'язком держави захищати права людини і пов'язують існування судового механізму захисту конституційних прав i свобод.

\section{2. Правова природа та сучасне розуміння механізму судового захисту конституційних прав людини.}

\section{1. Становлення концепції судового захисту конституційних прав людини}

Від початку підгрунтям для створення незалежного суду стала теорія розподілу влад та захисту від свавілля держави. Зокрема, М. Савчин зауважує, що запровадження правосуддя здійснюється з метою запобігання свавіллю виконавчої влади. Судовий контроль за актами діями/бездіяльністю публічної адміністрації $\epsilon$ важливим елементом верховенства права та забезпечення поваги до прав людини [24, с. 253].

У Висновку № 1 (2001) Консультативної ради європейських суддів для Комітету міністрів Ради Європи про стандарти незалежності судових органів та незмінюваність суддів зазначається, що судова влада $\epsilon$ однією із трьох рівних засад сучасної демократичної держави. Судова влада відіграє важливу роль та виконує серйозні завдання стосовно двох інших засад. Ця влада забезпечує відповідальність урядів та органів державного управління за свої дії, а також, щодо законодавчої влади, судова влада бере участь у процесі виконання відповідним чином прийнятих законів та більшою чи меншою мірою в тому, щоб забезпечити відповідність цих законів усім положенням Конституції чи права більш високого рівня (як, наприклад, права Європейського союзу) [2].

Водночас нині науковці починають досліджувати захист прав людини як ключову роль суду. Так, В. Бігун розглядає зміст правосуддя як судовий захист права, яким називає «правозахисний смисл правосуддя» [1]. Б. Малишев, наприклад зазначає про процедуру здійснення функції 
судової влади, до якої належать: розгляд справ, захист прав і свобод людини і громадянина, охорона конституційного ладу $[8$, с. 24, 26].

На наше переконання, дослідження сутності судового захисту конституційних прав доцільно розглядати саме через призму відносин людина - держава, в контексті виконання державою своїх універсальних зобов'язань захищати права людини. Водночас в першу чергу на становлення ідеї щодо захисту конституційних прав як функції суду вплинув розвиток концепції прав людини. Відтак у зв'язку зі зміною розуміння прав людини та зобов'язань держави щодо їх утвердження i захисту відбулася зміна пріоритетності функцій суду - від органу, що вирішує спір - контролює інші гілки влади - до інституції, що здійснює захист конституційних прав.

Ураховуючи генезис та становлення ідеї прав людини, пропонуємо виокремити такі етапи розвитку механізму судового захисту конституційних прав людини:

1. Перший етап охоплює період після буржуазних революцій (Декларація прав людини, Франція, Конституція США 1787). Саме тоді здійснюється визнання на національних рівнях основоположних прав, створюються національні режими судового захисту. Роль суду запобігти свавіллю, здійснюючи контроль за іншими гілками влади.

2. Другий етап розпочався після прийняття Загальної декларації прав людини 1948 року, Білля про права (Міжнародні пакти, низка Конвенцій, що регулюють окремі питання прав людини). У цей період відбулося закріплення на міжнародному рівні основоположних прав - держави взяли на себе ключові зобов'язання щодо прав людини: дотримуватися, сприяти, захищати. Виникає концепція ефективного засобу юридичного захисту. Створюється міжнародний режим судового захисту - система міжнародних судових та квазі-судових установ. Особливість міжнародного захисту полягає в контролі за 
виконанням державами своїх міжнародних зобов'язань відповідно до конвенцій. Паралельно відбувається імплементація міжнародних стандартів прав людини у національні конституції.

3. Третій етап пов'язаний зі становленням та розвитком регіональних режимів захисту прав людини: Європейського (створення Ради Європи, прийняття ЄКПЛ), Міжамериканського, Азійського, Африканського та охоплює період з початку 1950-х років. Для контролю за додержанням державами-учасницями вищезгаданих конвенцій своїх зобов'язань також створюються контролюючі судові органи: ЄСПЛ, Африканський суд із прав людини і народів, Міжамериканський суд із прав людини.

Ці судові установи не є черговими інстанціями після національних судів, на що неодноразово наголошували відповідні суди у своїх рішеннях. Так, наприклад, умовою для звернення до ЄСПЛ є вичерпання всіх національних засобів юридичного захисту, але тільки тих, які Судом буде визнано ефективними в розумінні статті 13 Конвенції. Тож правова природа цих судів полягає в тому, що ці суди слідкують за дотриманням державами-учасницями прав, гарантованих конвенціями та мають повноваження застосовувати заходи юридичного впливу на державупорушника. Якщо держава зазнає «failure» щодо виконання своїх зобов'язань із прав людини - лише в такому випадку регіональний механізм судового захисту може бути застосовано.

4. Четвертий етап пов'язаний з інтеграцією держав та створенням конституційних надпорядків, наприклад утворення Європейського Союзу. У зв'язку із цим виникає конкуренція юрисдикцій (між національними і наднаціональними судами, між ЄСПЛ та Судом ЄС, між конституційними судами та ЄСПЛ, Судом ЄС) ${ }^{4}$.

4 Детальніше див. М. Савчин. Порівняльне конституційне право: навчальний посібник. Київ : Юрінком Інтер, 2019, 328 с. 
Права людини в Україні та у зарубіжних країнах:

проблеми теорії та нормативно-правової регламентації

\section{2. Правова природа судового захисту прав людини}

Узагальнивши напрацювання філософії права, теорії права, конституційного права та прав людини, дослідивши міжнародні та національні нормативно-правові положення, що стосуються судового захисту, практику їх застосування, можна говорити про множинну природу категорії судового захисту.

Судовий захист як основоположне право. Зазначене право закладено в низці міжнародних документів з прав людини (статті 8-10 Загальної декларації прав людини, стаття 14 Міжнародного пакту про громадянські та політичні права, стаття 6 Європейської конвенції із прав людини, стаття 47 Хартії Основних прав ЄС тощо). Водночас це право $є$ i одним із найбільш «вразливих». Зокрема, як свідчить статистика рішень ЄСПЛ, близько 40\% порушень, констатованих судом, стосуються статті 6 Конвенції, а саме справедливого судового розгляду (16,86\%) та тривалості процедур (21,41\%) [33].

Положення щодо права на судовий захист знайшли відображення в національних конституціях та практиці конституційних судів. Так, Конституційний суд України в одному 3 рішень зазначає: «Конституційне право на судовий захист належить до невідчужуваних та непорушних. Кожен під час розгляду будь-якої справи, в тому числі кримінальної, щодо діяння, у вчиненні якого обвинувачується, має право на правосуддя, яке відповідало б вимогам справедливості» (абзац перший пункту 5 мотивувальної частини ) [18]. Право на судовий захист включає в себе, зокрема, можливість оскарження судових рішень в апеляційному та касаційному порядку, що $\epsilon$ однією з конституційних гарантій реалізації інших прав і свобод, захисту їх від порушень і протиправних посягань, в тому числі від помилкових і неправосудних судових рішень. (абзац дев'ятий підпункту 2.1 пункту 2 мотивувальної частини ) [19].

Деякі науковці також зазначають: «право на судовий захист - це передбачена законодавством можливість 
фізичних та юридичних осіб захищати свої права в судах загальної і конституційної юрисдикції. Це право слід розглядати двояко: 3 одного боку, як одне 3 конституційних прав людини в державі нарівні з іншими політичними, економічними, соціальними й культурними правами, а з іншого - як право, що закріплює спеціальний механізм захисту всіх без винятку вищезазначених прав» [3, с. 12]. Право на судовий захист також розглядається як «спосіб захисту прав, свобод і законних інтересів учасників суспільних правовідносин - фізичних та юридичних осіб» [25, с. 29]; «гарантований Конституцією правовий інструмент, за допомогою якого суб'єкти права можуть добитися відновлення порушеного права» [26, с. 4].

Судовий захист як гарантія основоположних прав. Як зазначає Управління Верховного комісара ОOH із прав людини у рекомендаціях державам щодо імплементації прав людини під час розроблення конституцій, «судова система лежить в основі гарантій прав людини. По-перше, суд захищає окрему особу чи групи осіб від свавільних дій держави, таких як позбавлення волі, експропріація без законних підстав та/або справедливої компенсації, або невиправдане позбавлення соціальних послуг. По-друге, судові органи надають окремим особам або групам осіб можливість переглядати i вирішувати їх справи незалежним, компетентним та неупередженим органом. По-третє, рішення судової влади, зокрема рішення, прийняті вищим апеляційним судом або конституційними судами, можуть впливати на державну політику та законодавство, наприклад, переглядаючи конституційність закону чи рішень або розглядаючи судові справи в інтересах суспільства. Отже, як міжнародне право в галузі прав людини, так і сучасний конституціоналізм надають великого значення праву на доступ до судів, праву на апеляцію та праву на конституційну скаргу» [31, с. 107].

Подібні ідеї містяться в низці рішень Конституційного суду України: «Судовий контроль за правомірністю порушення кримінальної справи $є$ дієвою гарантією прав і 
свобод людини і громадянина, що забезпечує реалізацію права особи на судовий захист та не допускає зловживань із боку посадових та службових осіб правоохоронних органів (абзаци перший, третій, четвертий підпункту 3.2 пункту 3 мотивувальної частини ); право на судовий захист $\epsilon$ конституційною гарантією прав і свобод людини i громадянина, а обов'язкове виконання судових рішень складовою права на справедливий судовий захист (абзац п'ятий підпункту 2.1 пункту 2 мотивувальної частини) [20]; право кожного на судовий захист є однією 3 конституційних гарантій реалізації інших прав і свобод, захисту їх від порушень i протиправних посягань (абзац четвертий підпункту 2.1 пункту 2 мотивувальної частини) [23].

Судовий захист як ефективний засіб правового захисту. Стаття 2 Міжнародного пакту про громадянські та політичні права зобов'язує держави забезпечити ефективний засіб захисту. Стаття 13 ЄКПЛ передбачає право на ефективний засіб правового захисту, зазначаючи, що «кожна людина, чиї права та свободи, визнані в цій Конвенції, були порушені, має право на ефективний засіб юридичного захисту в національному органі, навіть якщо таке порушення було вчинене особами, які виступають в якості офіційної особи». Це одне із ключових положень, що лежить в основі системи захисту прав людини Конвенції, поряд із вимогами статті 1 про зобов'язання поважати права людини і статті 46 про виконання рішень ЄСПЛ [6].

Право на ефективний засіб правового захисту також відображає основоположну роль національних судових систем для системи Конвенції, якщо профілактичні заходи виявилися недостатніми. У цьому відношенні слід зазначити, що, на додаток до зобов'язання констатувати існування ефективних засобів правового захисту у світлі прецедентного права Суду, держави несуть загальний обов'язок щодо вирішення проблем, що лежать в основі порушень, знайдені в рішеннях Суду [14]. 
Судовий захист як механізм захисту прав людини. Право на судовий захист може виступати одночасно як правомгарантією, так і механізмом реалізації обов'язку держави гарантувати права і свободи громадян, які закріплені в Конституції, законах і передбачені міжнародними зобов'язаннями держави, що визнається одним із найбільш ефективних засобів захисту прав людини. Судовий захист серед усього спектру юридичних гарантій є основним, що зумовлено юридичною природою судової гілки влади, місцем суду $\mathrm{y}$ структурі державних органів, його функціональним призначенням [11].

На думку Конституційного суду України, забезпечення прав i свобод потребує, зокрема, законодавчого закріплення механізмів (процедур), які створюють реальні можливості для здійснення кожним громадянином прав і свобод (абзац четвертий підпункту 3.2 пункту 3 мотивувальної частини Рішення Конституційного Суду України від 24 грудня 2004 року № 22-рп/2004). До таких механізмів належить структурована система судів і види судового провадження, встановлені державою (речення друге - четверте абзацу першого підпункту 3.2 пункту 3 мотивувальної частини ) [21]. Судовий захист прав і свобод людини i громадянина необхідно розглядати як вид державного захисту прав і свобод людини і громадянина, i саме держава бере на себе такий обов'язок відповідно до частини другої статті 55 Конституції України [22]. Більше того, у правовій державі звернення до суду $\epsilon$ універсальним механізмом захисту прав, свобод та законних інтересів фізичних і юридичних осіб (абзац п'ятий підпункту 2.2 пункту 2 мотивувальної частини ) [16].

\section{3. Особливості механізму судового захисту конституційних прав людини}

Під захистом (прав) зазвичай розуміють цілісну систему правових форм, заходів та засобів, взаємодія яких направлена на утвердження або відновлення порушених прав і свобод людини і громадянина Таким чином, режим 
захисту прав людини активізується у випадку їх порушення [8, с.48]. У свою чергу, механізм захисту конституційних прав i свобод можна визначити як сукупність взаємопов'язаних процесів, елементів, а також зв'язків між ними, які виконують функцію реагування на порушення конституційних прав і свобод (реагування, у свою чергу, включає застосування правових засобів для припинення порушення, відновлення порушеного права, застосування заходів юридичної відповідальності тощо).

Наразі можна говорити про існування двох моделей захисту конституційних прав людини залежно від порядку та суб'єктів здійснення функції захисту: судової та позасудової. Судовий захист реалізується спеціально створеним органом - судом, який у процесі здійснення правосуддя виконує, в тому числі, функцію захисту прав людини. Позасудовий механізм передбачає захист в адміністративному порядку (в порядку діяльності суб'єктів публічної адміністрації), через звернення до національних правозахисних інституцій, або в порядку самозахисту тощо.

Таким чином, судовий захист конституційних прав людини є однією з моделей захисту конституційних прав людини в межах загальної системи захисту прав людини, що виступає гарантією виконання державами своїх зобов'язань щодо захисту прав людини. У зв'язку із цим абсолютно логічним видається те, чому держава несе відповідальність не лише у випадку безпосереднього порушення права, але i коли таке порушення було заподіяно у зв'язку з невиконанням рішення суду чи тривалою судовою процедурою. Хоча судова влада i $\epsilon$ незалежною гілкою влади, а гарантія незалежності $\epsilon$ ключовою в забезпеченні права на судовий захист, держава все ж відповідає за належну організацію судової системи і системи правосуддя таким чином, щоб належно i ефективно реалізувати свою функцію захисту.

Цю тезу однак слід сприймати з деяким застереженням. Незважаючи на те, що захист прав людини i основоположних свобод $€$ однією з функцій держави, 
власне механізм судового захисту конституційних прав не обмежується виключно державою чи національними механізмами. Навпаки, для того, щоб контролювати дотримання державою її універсальних зобов'язань щодо прав людини, створено розгалужену мережу наднаціональних інституцій, у тому числі і судових.

Ураховуючи викладене, механізм судового захисту конституційних прав і свобод можна визначити як систему (сукупність взаємопов'язаних процесів, елементів, а також зв'язків між ними), що забезпечує захист і відновлення судом конституційних прав людини.

Виходячи 3 функцій механізму судового захисту конституційних прав і свобод, можливо виокремити такі його сутнісні ознаки.

По-перше, ми поділяємо думку тих науковців, які пропонують розглядати механізм захисту прав людини в контексті «режимів», у межах яких він функціонує. Режим можна розтлумачити як систему механізмів, інституцій, нормативних та організаційних інструментів, що виконують правозахисну функцію [9]. Так, доцільним видається виокремити національний (в межах держави), регіональний (в межах регіональних систем захисту прав людини: Європейська (система Ради Європи та Європейського Союзу), Міжамериканська, Африканська тощо) та міжнародний (система ОOH, інших міжнародних організацій) режими функціонування механізму судового захисту конституційних прав людини.

По-друге, механізм судового захисту конституційних прав і свобод людини має два взаємозалежні аспекти: матеріальний (норми права, на основі яких механізм функціонує) та процесуальний (власне процедура функціонування механізму). Перший аспект дає відповідь на питання, що саме та за яких умов має бути здійснено у випадку порушення конституційного права, другий (процесуальний) аспект описує, яким чином має бути здійснено реагування у випадку порушення конституційного права. 
По-третє, в межах механізму судового захисту конституційних прав є, як мінімум, 3 суб'єкти: суб'єкт, конституційне право якого порушено; суб'єкт, який порушив відповідне право; суб'єкт реагування (суд). Суб'єкт реагування на порушення має бути наділений відповідними повноваженнями, мати у своєму розпорядженні ресурси для здійснення функції захисту та діяти в межах чітко визначеної процедури. Окрім того, для суб'єкта, наділеного конституційними правами, необхідно забезпечити відповідні інструменти звернення до суб'єкта реагування та поінформованість про порядок використання таких інструментів, а для суб'єкта реагування - інструменти припинення порушення, відновлення права та притягнення порушника до відповідальності. Складовими частинами судового механізму захисту конституційного права також слід визначити: гарантії конституційних прав i свобод (нормативні та інституційні), а також гарантії незалежності суду, правові засоби, спрямовані на відновлення порушеного права, застосування заходів юридичної відповідальності та відшкодування шкоди за порушення конституційного права.

\section{Висновки}

Судовий захист доцільно розглядати як одну з моделей захисту конституційних прав людини через призму виконання державою своїх універсальних зобов'язань захищати права людини (визначених міжнародними, регіональними стандартами 3 прав людини та національними конституціями). Саме такий підхід повною мірою ілюструє роль держави щодо забезпечення ефективної, незалежної судової системи, яка, з одного боку, забезпечує реалізацію основоположного права на доступ до суду, а з іншого - $є$ інституційною гарантією для інших основоположних прав людини. 
Виникнення, становлення та розвиток механізму судового захисту конституційних прав людини слід пов'язувати із процесом виникнення національних, регіональних та міжнародних режимів захисту прав людини та в контексті універсалізації обов'язків держави щодо прав людини: позитивних (утверджувати, захищати) та негативних (утримуватися від порушень). У свою чергу, саме 3 обов'язком держави захищати права людини i пов'язують існування судового механізму захисту конституційних прав і свобод.

Відтак у зв'язку зі зміною розуміння прав людини та зобов'язань держави щодо їх утвердження i захисту відбулася зміна пріоритетності функцій суду - від органу, що вирішує спір - контролює інші гілки влади - до інституції, що здійснює захист конституційних прав.

Ураховуючи генезис та становлення ідеї прав людини, пропонуємо розглядати такі етапи розвитку механізму судового захисту конституційних прав людини: перший етап, який охоплює період після буржуазних революцій (роль суду - запобігти свавіллю, здійснюючи контроль за іншими гілками влади); другий етап, пов'язаний із прийняттям ключових міжнародних документів у сфері прав людини (створюється міжнародний режим судового захисту - система міжнародних судових та квазі-судових установ); третій етап, що пов'язаний зі становленням та розвитком регіональних режимів захисту прав людини, та четвертий етап, ознаменований інтеграцією держав та створенням конституційних надпорядків (Європейський Союз).

Правова природа судового захисту конституційних прав людини характеризується множинністю. Так, у теорії, філософії права судовий захист розглядається як основоположне право; гарантія основоположних прав; ефективний засіб захисту; механізм захисту прав людини. Водночас механізм судового захисту конституційних прав і свобод пропонуємо визначити як систему (сукупність взаємопов'язаних процесів, елементів, а також зв'язків між 
ними), що забезпечує захист і відновлення судом конституційних прав людини.

До основних ознак механізму судового захисту конституційних прав нами віднесено такі: реалізація спеціально створеним органом - судом, який в процесі здійснення правосуддя виконує, в тому числі, функцію захисту прав людини; функціонування в межах «режимів» (національний, регіональний, міжнародний); існування двох взаємозалежних аспектів згаданого механізму: матеріального (норми права, на основі яких механізм функціонує) та процесуального (власне процедура функціонування механізму); особливість суб'єктного складу та наявність гарантій.

Ураховуючи стрімкий розвиток технологій та глобалізаційних процесів, перспективними, на нашу думку, $\epsilon$ подальші напрями дослідження механізму судового захисту конституційних прав з огляду на його подальшу трансформацію у зв'язку 3 інтеграцією в межах європейського простору, а також у контексті цифровізації доступу до правосуддя.

\section{Список використаних джерел:}

1. Бігун В.С. Філософія правосуддя: ідея та здійснення : монографія. Київ, 2011. 303 с.

2. Висновок № 1 (2001) Консультативної ради європейських суддів для Комітету міністрів Ради Європи про стандарти незалежності судових органів та незмінюваність суддів. URL: https://zakon.rada.gov.ua/laws/ show/994_a52.

3. Дашутін I.В. Правове регулювання судового захисту трудових прав громадян : автореф. дис... канд. юрид. наук : 12.00.05 / Національна юридична академія України ім. Ярослава Мудрого. Хаків, 2008. 20 с.

4. Дослідження практики Європейського суду з прав людини для визначення Національних стандартів компенсацій порушення державою прав людини : [інформаційно-аналітичний звіт] / M. Гнатовський, 
А. Федоров, К. Красовський, О. Власенкова. Київ : Атіка, 2011 p. 184 c.

5. История западной философии [B 2 т.] T. II, кн. 3 / Бертран Рассел; [перевод с английского]. Москва : Издательство АСТ, 2018. 512 c.

6. Керівництво з належної практики щодо національних засобів правового захисту (ухвалено Комітетом Міністрів 18 вересня 2013 року), Рада Європи, 2013 рік. URL: https://rm.coe.int/k-/1680695aab.

7. Кочура Е. Понятие и элементы конституционноправового механизма защиты прав и свобод человека и гражданина. Legea şi viaţa. 2015. № 4/2(280). C. 47-52.

8. Малишев Б. В. Судовий прецедент у правовій системі Англії. Київ : Юридична думка, 2008. 303 с.

9. Манукян В.И. Международная защита прав человека: право, прецеденты, комментарии : Научно-практическое пособие. Киев : Истина, 2010. 480 с.

10. Міжнародний пакт про громадянські та політичні права. URL: https://zakon.rada.gov.ua/laws/show/995_043.

11. Остапенко В.В. Гарантії суб'єктивних прав і свобод як елемент правового статусу людини і громадянина. Теорія і практика правознавства. 2018. Вип. 1(13).

12. Отфрид Гьоффе. Трансцендентальний обмін фігура легітимації прав людини? Філософія прав людини / За редакції Ш. Госепата та Г. Ломанна ; пер. з нім. О. Юдіна та Л. Доронічевої. Київ : Ніка-Центр, 2016. 320 с.

13. Рекецька I.P. Судова влада в контексті демократичної трансформації українського суспільства : автореф. дис...канд. політ. наук : 23.00 .02 / Одеська національна юридична академія. Одеса, 2003.16 с.

14. Рекомендація Rec (2004) 6 Комітету міністрів Ради Європи державам-членам «Щодо вдосконалення національних засобів правового захисту». URL: https://zakon.rada.gov.ua/laws/show/994_718.

15. Рішення Конституційного Суду України у справі за конституційним зверненням акціонерної компанії 
«Харківобленерго» щодо офіційного тлумачення положень пункту 2 частини другої статті 17, пункту 8 частини першої статті 26, частини першої статті 50 Закону України «Про виконавче провадження» від 26 червня 2013 року № 5-рп/2013. Вісник Конституційного Суду України від 2013. № 4. C. 17.

16. Рішення Конституційного Суду України у справі за конституційним зверненням громадянина Трояна Антона Павловича щодо офіційного тлумачення положень статті 24 Конституції України (справа про рівність сторін судового процесу) від 12 квітня 2012 року № 9-рп/2012. Вісник Конституційного Суду України від 2012 р. № 3. С. 41.

17. Рішення Конституційного Суду України у справі за конституційним поданням Уповноваженого Верховної Ради України 3 прав людини щодо відповідності Конституції України (конституційності) положення третього речення частини першої статті 13 Закону України «Про психіатричну допомогу» (справа про судовий контроль за госпіталізацією недієздатних осіб до психіатричного закладу) від 1 червня 2016 року № 2-рп/2016. Вісник Конституційного Суду України від 2016, № 6. С. 60.

18. Рішення Конституційного Суду України у справі за конституційним поданням Верховного Суду України щодо відповідності Конституції України (конституційності) положень статті 69 Кримінального кодексу України (справа про призначення судом більш м'якого покарання) від 2 листопада 2004 року 15-рп/2004. Голос України від 11.01.2005. № 3.

19. Рішення Конституційного Суду України у справі за конституційним поданням Уповноваженого Верховної Ради України 3 прав людини щодо відповідності Конституції України (конституційності) положень частини другої статті 171-2 Кодексу адміністративного судочинства України від 8 квітня 2015 року № 3-рп/2015. Вісник Конституційного Суду України від 2015. № 3. С. 28.

20. Рішення Конституційного Суду України у справі за конституційним поданням Верховного Суду України щодо 
відповідності Конституції України (конституційності) положень частин сьомої, дев'ятої, пункту 2 частини шістнадцятої статті 236-8 Кримінально-процесуального кодексу України від 30 червня 2009 року № 16-рп/2009. Вісник Конституційного Суду України від 2009 р. № 5. С. 6.

21. Рішення Конституційного Суду України у справі за конституційним поданням Верховного Суду України щодо відповідності Конституції України (конституційності) положень Закону України «Про внесення змін до деяких законодавчих актів України щодо підвідомчості справ, пов'язаних із соціальними виплатами» від 9 вересня 2010 року № 19-рп/2010. Вісник Конституиійного Суду України від 2010 р. № 5. С. 25.

22. Рішення Конституційного Суду України у справі за конституційним поданням Президента України щодо офіційного тлумачення положень частин другої, третьої статті 124 Конституції України (справа щодо підвідомчості актів про призначення або звільнення посадових осіб) від 7 травня 2002 року № 8-рп/2002. Вісник Конституційного Суду України від 2002 р. № 2. С. 29.

23. Рішення Конституційного Суду України у справі за конституційними поданнями Верховного Суду України щодо відповідності Конституції України (конституційності) положень частини третьої, абзаців першого, другого, четвертого, шостого частини п'ятої статті 141 Закону України «Про судоустрій і статус суддів» та положень пункту 5 розділу III «Прикінцеві положення» Закону України «Про внесення змін до деяких законодавчих актів України щодо пенсійного забезпечення» (справа про щомісячне довічне грошове утримання суддів у відставці) від 8 червня 2016 року № 4-рп/2016. Вісник Конституційного Суду України від 2016 р. № 6. С. 97.

24. Савчин М.В. Порівняльне конституційне право: навчальний посібник. Київ : Юрінком Інтер, 2019. 328 с.

25. Сірий М.I. Право на судовий захист. Юридична енциклопедія / ред. Ю.С. Шемшученко [та ін.] ; НАН України, Ін-т держави і права ім. В.М. Корецького. Київ : Вид-во 
«Українська енциклопедія» ім. М.П. Бажана, 1998. Т. 5 : П-С. Київ : [б.в.], 2003. 736 с.

26. Тимченко Г.П. Способи та процесуальні форми захисту цивільних прав : автореф. дис... канд. юрид. наук : 12.00 .03 ; Нац. юрид. акад. України ім. Я. Мудрого. Харків, 2002. $20 \mathrm{c}$.

27. Філософія прав людини / За редакції Ш. Госепата та Г. Ломанна ; Пер. $з$ нім. О. Юдіна та Л. Доронічевої. Київ : Ніка-Центр, 2016. Серія «Зміна парадигми», Вип. 13. 320 с.

28. Філософія свободи / Ларс Фр. Г. Свендсен ; пер. 3 норвезьк. Львів : Видавництво Аннети Антоненко ; Київ : Ніка-Центр, 2016. 336 с.

29. Brian Z. Tamanaha. On the Rule of Law: History, Politics, Theory. NY, Cambridge University Press, 2009.180 p.

30. Déclaration des droits de l'Homme et du citoyen de 1789. URL: http://www.textes.justice.gouv.fr/textesfondamentaux-10086/droits-de-lhomme-et-libertesfondamentales-10087/declaration-des-droits-de-lhomme-etdu-citoyen-de-1789-10116.html.

31. Human Rights and Constitution Making. United Nations publication issued by the Office of the United Nations High Commissioner for Human Rights (OHCHR), 2018. URL: https://www.ohchr.org/Documents/Publications/Constitution Making_EN.pdf.

32. Jayawickrama N.. The Judicial Application of Human Rights Law: National, Regional and International Jurisprudence. Cambridge : Cambridge University Press. 965 p.

33. Overview 1959-2019. European Court of Human Rights, February 2020. URL: https://www.echr.coe.int/Documents/ Overview_19592019_ENG.pdf.

34. Vienna Declaration and Programme of Action, adopted by the World Conference on Human Rights in Vienna on 25 June 1993. URL: https://www.ohchr.org/en/professionalinterest/ pages/vienna.aspx. 
Права людини в Україні та у зарубіжних країнах:

проблеми теорії та нормативно-правової регламентації

DOI https://doi.org/10.36059/978-966-397-210-7/283-305

\author{
Любченко М. I., \\ кандидат юридичних наук, \\ доцент кафедри теоретико-правових дисциплін \\ Полтавського юридичного інституту \\ Національного юридичного університету \\ імені Ярослава Мудрого, \\ м. Полтава
}

Буряковська К. О.,

кандидат юридичних наук,

асистент кафедри теорії і філософії права

Національного юридичного університету

імені Ярослава Мудрого,

м. Харків

\title{
СУЧАСНИЙ МІЖНАРОДНИЙ ПРАВОПОРЯДОК У КОНТЕКСТІ СТ. 28 ЗАГАЛЬНОЇ ДЕКЛАРАЦІЇ ПРАВ ЛЮДИНИ
}

Анотація. У підрозділі розглянуто проблему справедливого міжнародного ладу в контексті проголошеного у ст. 28 Загальної декларації прав людини права кожного на такий міжнародний порядок, який зробить можливим повну реалізацію прав людини. Автор з'ясовує нормативні засади побудови міжнародних відносин та співробітництва після заснування Організації Об'єднаних Націй та прийняття Загальної декларації прав людини. Також досліджуються основні виклики, які стоять перед міжнародним правопорядком сьогодні, особливо пов'язані із правами людини. Розглядається теорія глобальної справедливості як така, що адекватна тим запитам на справедливий світ, які проголошені в низці документів під егідою ООН і не тільки. Проводиться аналіз можливості застосування ідеї справедливості, що зазвичай використовується в контексті національного правопорядку, до міжнародних відносин у широкому сенсі. З'ясовується, що у глобальному вимірі на перший 
Права людини в Україні та у зарубіжних країнах:

проблеми теорії та нормативно-правової регламентації

план виходить дистрибутивний аспект справедливості. Досліджено концепцію сталого розвитку та їі співвідношення з ідеєю сталого розвитку.

\section{Вступ}

Загальну декларацію прав людини, прийняту Генеральною асамблеєю ООН 10 грудня 1948 року, тобто більш ніж 70 років тому, беззастережно можна назвати найголовнішим документом, який вплинув на долю людства та назавжди змінив світовий порядок. Цей акт глобального рівня засвідчив те, що посягання на людську гідність вже не може розглядатись як допустиме взагалі, i на порядку денному стоїть «створення такого світу, в якому люди будуть мати свободу слова і переконань і будуть вільні від страху і нужди» (Преамбула Загальної декларації прав людини). Декларація стала вдалим компромісом різних інтересів політичних сил, які одержали перемогу над фашистськими державами, і у 1948 році цей компроміс був вдало «підхоплений» та зафіксований, адже, як справедливо відзначають у літературі, що така згода і згуртованість навколо ідеї прав людини за часів «холодної війни» уже б була неможлива, що було продемонстровано під час прийняття наступних конвенцій $\mathrm{OOH}$ та інших угод про права людини [10]. Проте це не спинило того правозахисного розвитку, поштовхом та натхненням для якого стала Декларація, попри те, що вона не містить жодних зобов'язань для держав [10]. Найбільшою цінністю Декларації $\epsilon$ те, що вона перетворила ідею (наш курсив) прав людини у реальність - права людини стали тим нормативним мірилом, яке претендує на загальну всесвітню значущість і яке вже не можна ігнорувати [10].

Схоже, це та цінність, яку важко оцінити повною мірою, «справедливість, і свобода, коли вони наявні, стають подібними повітрю», «свідомість не фіксує справедливість», коли вона виражає досягнуту для даного історичного періоду гармонійність, оптимальність людських відносин [16]. 


\section{1. Сучасний міжнародний порядок та ідея прав людини}

Загальна декларація прав людини являє собою каталог прав людини, які можна згрупувати на фізичні, особистісні, культурні, економічні, політичні - залежно від потреб та інтересів людини, а також на колективні, індивідуальні та колективно-індивідуальні - залежно від носї̈в потреб та можливостей реалізації [15, с.35]. Привертають увагу, а точніше ставлять питання про своє місце у структурі та ідеї Декларації, три останні її статті - 28, 29 і 30, адже за своїм змістом вони проголошують загальні умови здійснення прав, передбачених основним текстом Декларації та принципів тлумачення документа, і на перший погляд не проголошують змістовних прав $[15$, с.72]. Як відомо, структура прийнятої Декларації була розроблена французьким правником Рене Кассеном, який порівнював Декларацію з грецьким храмом із фундаментом, східцями, колонами і фронтоном: колони групи прав людини, фундамент - 1 і 2 статті Декларації, сім абзаців Преамбули - сходинки до самої Декларації; останні ж три статті являють собою фронт храму [31, с.100]. С. Рабінович звертає увагу на те, що розміщення статей 28-30 Декларації наприкінці її тексту зумовлене не їх малозначністю, як може здатись, а «загальною логікою «вертикальної» архітектоніки Декларації, організацією розгортання смислів від преамбули і до завершення документа, яке постає радше його вершиною, аніж кінцем» $[15$, c. 72$]$.

Стаття 28 Загальної декларації прав людини проголошує: кожна людина має право на соціальний i міжнародний порядок, при якому права i свободи, викладені в цій Декларації, можуть бути повністю здійснені. В англомовній, оригінальній версії текст цієї статті звучить так: «Everyone is entitled to a social and international order in which the rights and freedoms set forth in this Declaration can be fully realized». "To entitle» перекладається як надавати право, уповноважувати [3]. Чи $\epsilon$ такий переклад статті Декларації українською еквівалентним та чи враховує усі нюанси? Як стає 
Права людини в Україні та у зарубіжних країнах:

проблеми теорії та нормативно-правової регламентації

зрозуміло із історії створення Декларації, на етапі розробки ії авторами було виконано стилістичну заміну «right to» на «entitled to», щоб уникнути тавтології [25, с. 8]. У літературі підкреслюється, що виникає у ст. 28 проголошене sui generis суб'єктивне «мета-право» прав людини: їі право на такий соціальний і міжнародний порядок, у якому можуть бути повністю здійснені викладені в Декларації права і свободи [15, с. 72].

Томас Погге, обгрунтовуючи права людини як моральні вимоги до глобальних інституцій, вважає, що моральне прочитання ст. 28 Декларації звучить так: «Системи інституцій, включаючи глобальну, підлягають переоцінці та реформуванню з урахуванням їхнього відносного внеску в реалізацію прав людини». Т. Погґе звертає увагу на те, що положення ст. 28 не указують на те, яким саме має бути соціальний порядок у наших державах та якими мають бути глобальні інституції, але визначальним критерієм організації цих порядків він вважає те, чи «їх можна реконструювати» відповідно до мети повноцінної реалізації прав людини.

у філософсько-правовій літературі досить багато привернуто уваги питанню справедливого влаштування світу. До, прикладу, П. Коллер виділяє три моделі міжнародного устрою та намагається проаналізувати, як реалізується в них справедливість та права людини:

1) модель розділених самодостатніх окремих суспільств, які мають ресурси і між собою тісно не взаємодіють; тут люди максимум можуть розраховувати на отримання політичного притулку в інших, ніж їх громадянство, державах; при цьому недоступними буде свобода пересування світом та право бідних народів отримати допомогу від багатих;

2) модель усеохоплюючого світового порядку, тобто світ, де нації вплітаються у глобальну кооперацію, держави виконують функції адміністративних єдностей. Тут права людини мають глобальний зобов'язуючий характер, але для цього потрібен відповідний глобальний устрій, де 
будуть забезпечені ліберальні свободи, громадянські, політичні та соціальні права. При цьому національні держави перестають існувати як відносно самостійні політичні спільноти і підпорядковуються наддержавному органу влади з достатніми законодавчими та примусовими повноваженням. Такий світ нівелює різноманіття форм суспільного життя;

3) модель взаємозалежних національних суспільств. Вона $\epsilon$ моделлю всеохоплюючого світового суспільства, але при цьому враховує умови різноманіття відносно самостійних політичних спільнот. Абсолютними та глобальними тут $є$ обов'язки непосягання, тобто негативні обов'язки, а обов'язки позитивних дій покладаються власне на громадян та державні інституції кожного окремого суспільства. Інтернаціоналізація прав людини відбувається у трьох напрямках: 1) дотримання прав людини в усіх державах світу, що вимагає відповідних форм міжнародної кооперації та транснаціональних інституцій, які б покладали на держави зобов'язання дотримуватись прав людини, а також існування міжнародно-правових механізмів притягнення держав до відповідальності. П. Коллер вважає, що міждержавні санкції у сучасному вигляді не обіцяють бути дієвими, адже в більшості випадків такі санкції не досягають своєї мети, посилюють взаємне протистояння, ізолюють громадян держави від зовнішнього світу та $\epsilon$ ризик того, що вони можуть завершитись потужним конфліктом. Застосування та продовження санкцій, як вважає П. Коллер, повинне засновуватись на принципі обачності; 2) запровадження свободи пересування світом для всіх людей, що означає право кожної людини вирушати у будь-яку країну за своїм вибором і там залишатись у відповідності до тих правил, які встановлені державою; 3) справедливий розподіл витрат та здобутків у межах міжнародної кооперації та користуванні природними ресурсами. Існує чимало держав, де люди не мають засобів для гідного життя, що вимагає кардинальної перебудови наявної світової системи, 
справедливого перерозподілу природніх ресурсів, а також перебудови держави - в напрямку підвищення освітніх послуг та посилення доступу людей до інформації, підвищення рівня медичних послуг, скорочення народжуваності. П. Коллер вважає, що наявні механізми відшкодування збитків, завданих несправедливими рішеннями, не можуть вирішити повною мірою ситуацію [9, с. 100-104].

Питання про облаштування післявоєнного світового порядку за новими правилами залишаються актуальними увесь час протягом 70 років. Варто почати 3 того, що загальноприйнятим $\epsilon$ розуміння того, що досягнення тих цілей, які продиктовані Загальною декларацією прав людини, $€$ можливим лише за рахунок міжнародної кооперації, яка заснована на волі та усвідомленості усіх держав. Про це наголошується в самій Декларації (п. 6 Преамбули), де вказується, що справа захисту прав людини відтепер стає предметом співробітництва між державами. Раніше, у п. 3 ст. 1 Статуту Організації Об'єднаних Націй 1945 року, було вказано, що завданням цієї глобальної структури $\epsilon$, зокрема, здійснення міжнародного співробітництва «у сфері розв'язання міжнародних проблем економічного, соціального, культурного та гуманітарного характеру й у заохоченні та розвитку поваги до прав людини й основних свобод для всіх, без розрізнення раси, статі, мови та релігії». Відданість ідеї міжнародної кооперації була відтворена далі у багатьох інших документах найвищого світового рівня, якими держави світу виражали свою відданість цьому принципу та поглиблювали його зміст. Через майже півстоліття у 1993 році 171 державою світу було прийнято Віденську Декларацію та Програму дій, яка стала кульмінацією Всесвітньої конференції з прав людини, де заохочення і розвиток поваги до прав людини і основних свобод для «всіх i повагу принципу рівноправності i самовизначення народів світу, демократії, справедливості, рівності, законності, плюралізмі, розвитку, кращих умов 
життя і солідарності» було основою бажаного та омріяного міжнародного порядку [1]. Неможливо у цьому контексті не відзначити Декларацію про принципи міжнародного права, що стосуються дружніх відносин і співробітництва між державами відповідно до Статуту ООН, яка разом і 3 положеннями Гельсінського заключного акту Наради 3 безпеки і співробітництва в Європі 1975 р. сформували, як зазначає О. Задорожній, «десять заповідей міжнародного права», ключових для цієї системи, без яких саме ії існування неможливе». Професор О. Задорожній наголошує на тому, що сучасний світовий порядок, «заснований на співпраці держав в умовах миру та безпеки може зберігатися лише за умови загального визнання та поваги до цих принципів» [7]. Зокрема, йдеться про принципи, згідно з якими держави вирішують свої міжнародні спори мирними засобами таким чином, щоб не ставити під загрозу міжнародний мир і безпеку та справедливість, й принцип незастосування сили та погрози нею.

Г. Христова підкреслює, що заснування ООН у 1945 році, а також наступні процеси деколонізації призвели до перегляду доктрин класичного міжнародного права та конституціоналізму - доктрини державного суверенітету $[17$, c. 57]. Відповідно до цієї доктрини жодна держава не може бути пов'язана жодною нормою, якщо вона не надавала згоди на таку норму, тому лише два джерела міжнародного права могли застосовуватись до держави: міжнародні договори та міжнародні звичаї (tacitus consensus). Це означало, як слушно відзначає О. Київець, що міжнародні економічні та політичні відносини, які почали у середині XX ст. розвиватись небаченими до тих пір темпами, ризикували не засновуватись на природних правах людини. Досвід другої світової війни та рішення Нюрнберзького й Токійського трибуналів це довели [8, c. 146]. Зокрема, вони призвели до того, що людина стала суб'єктом міжнародного права та отримала безпрецедентну можливість звертатись до міжнародних органів за захистом своїх прав. Г. Христова вважає, що ці 
процеси призвели до наступних безповоротних зрушень у розвитку ідеї прав людини:

1) держави, які ратифікували міжнародні договори у сфері прав людини, зобов'язались поважати права людини не стільки перед іншими державами, скільки перед особами, які перебувають під їхньою юрисдикцією, тобто перед громадянами, особами 3 громадянством інших держав, особами без громадянства, особами, які шукають притулку, мігрантами;

2) виконання державами зобов'язань у сфері прав людини в межах національного правопорядку може бути оцінено на національному та міжнародному рівнях уповноваженими судовими (чи квазі-судовими) установами, що тягне за собою відповідальність держави за їх порушення;

3) за державами визнається широка свобода обирати способи, якими вони реалізовуватимуть свої зобов'язання держав, яка все одно має свої межі, що в термінології міжнародного права прав людини носить назву «свобода розсуду» («margin of appreciation») [17];

4) варто додати також, що нині доктрина прав людини стоїть на тому, що недержавні суб'єкти - національні та міжнародні неурядові організації, корінні народи та національні меншини; правозахисники; терористи; воєнізовані групи; автономні округи; інтернаціоналізовані території; транснаціональні корпорації; нарешті, самі індивіди - значно впливають на права людини інших, у рівній мірі, опікуючись та потураючи порушенням або порушуючи права людини. «Горизонтальна дія» прав людини як складова ідеї прав людини сьогодні передбачає, що кожна людина і кожна суспільна структура зобов'язані робити свій внесок у створення атмосфери, що сприяє здійсненню прав людини, i це зобов'язання $\epsilon$ універсальним і стосується всіх як державних, так i недержавні акторів (суб'єктів). [17, с. 50].

Пригадаємо, що ст. 28 Декларації вимагає від держав та міжнародного устрою повної реалізації прав людини. 
Що це може означати і які $\epsilon$ загрози цій повноцінній реалізації прав людини? Тут можна навести славнозвісне визначення Європейського суду з прав людини, зроблене ним у справі Airey v. Ireland (1979) про те, що права людини мають бути практичними та ефективними, а не теоретичними та ілюзорними (§ 24). Теоретичність та ілюзорність як протиставлення практичній та повноцінній реалізації прав людини, можна допустити, означає те, що для когось права людини, визнані на універсальному рівні, стають недоступними взагалі або їх реалізація $\epsilon$ неможливою у повній мірі. Т. Погґе вважає, що «надійна можливість отримання всіма людьми певних невід'ємних благ є змістом і метою офіційних декларацій з прав людини і власне прав людини» [14]. Сьогодні це твердження $\epsilon$ справжнім викликом для багатьох держав у світі: брак рівності та справедливості має місце у всіх регіонах світу.

\section{2. Ідея глобальної справедливості: відповідь на нові виклики}

Тепер уже безсумнівним стало те, що справа прав людини стала справою глобального характеру. Справді, дуже багато проблем, з якими люди стикаються сьогодні вимушена міграція, зміни клімату, нерівність, економічні коливання чи порушення прав людини - мають сильний міжнародний і часто навіть глобальний вимір. Процеси глобалізації впливають на права людини у великій мірі, i примітним $є$ те, що цей вплив має як негативний характер, так і позитивний. Це означає, що глобалізаційні процеси можуть породжувати численні виклики для прав людини, але водночас містять ряд переваг та інструментів, що $\epsilon$ більш дієвими для реагування на загрози правам людини різного рівня та виду. Глобалізація, яка здебільшого розуміється як світова економічна уніфікація, відкрила безпрецедентні можливості для соціального i економічного розвитку, але в той же час викликала серйозні проблеми, такі як широкомасштабні фінансові кризи, ізоляцію і нерівність як всередині суспільств так і 
між ними, все більше число людей у різних країнах і навіть цілі регіони залишаються на периферії глобальної економіки [6].

Сьогодні на рівні Організації Об'єднаних Націй визнається вплив на права людини процесів глобалізації, особливо глобальної економіки, наслідки якого часто носять уже не економічний характер, а зачіпають найцінніше, що заявлене Загальною декларацією прав людини - гідність людини. Загрози правам людини, які створені інтенсифікацією економічних відносин доповнились загрозами безпеки, коли, як пишуть дослідники, «після 11 вересня - замість кантівського проекту вічного миру, що передбачав республіканський уряд, федеративний лад, усесвітнє право на тлі загального страху та незахищеності першочерговими стають турбота про безпеку та виживання, бажання панувати та розподіляти, але також постає гостра потреба справедливості та рівності серед незахищених верств населення у цьому «релятивному, самогубному і розчарованому світі» $[14$, c. 8$]$.

Глобальна справедливість - це теорія у межах вчення про міжнародні відносини, що фокусується на важливості особистості на відміну від держави, громади чи культури. Ця теорія, по суті, виступає своєрідною відповіддю на те, як зробити сучасний світ справедливим, і нагадує, що об'єднуючою ідеєю цілком може бути людина. Теорія глобальної справедливості існує в рамках ширшої школи космополітизму, який $є$ «багаторівневою» теорією, що має політичний, правовий, культурний та економічний вимір. Правовий космополітизм головним чином стосується справедливості в світовому масштабі і дотримання прав людини; він $\epsilon$ своєрідним викликом «винятковим привілеям націй-держав діяти як верховний арбітр у питаннях, які стосуються того, що слід або не слід вважати порушенням прав людини на своїй території» [2]. Варто відзначити те (і це має важливе значення для розуміння теорії справедливості), що синонімічною назвою 
глобальної справедливості $\epsilon$ «глобальна етика», що акцентує увагу на таких дилемах справедливості, які вимагають ретельного дослідження та відповідного реагування на них, як: «війна 3 тероризмом», недобросовісні країни, використання дитячої праці, застосування тортур в умовах їх абсолютної заборони, обмеженість ресурсів, торгівля людьми, міграція, зміни клімату, глобальна торгівля, медичний туризм, глобальні пандемії, гуманітарна інтервенція та багато інших [32]. Саме фокус на моральній цінності особистості, що здебільшого притаманне теоріям справедливості, які традиційно обмежуються національними державами i містяться в царині політичної (а не міжнародної) теорії, став поштовхом до появи та розвитку теорії глобальної справедливості, яка прагне дослідити питання про те, як найкраще забезпечити справедливе життя для всіх людей на планеті Земля, незалежно від їх національності чи статусу [20].

Американський професор Фрейзер Н., виступаючи на всесвітньому конгресі 3 філософії права і соціальної філософії, присвяченому справедливості у сучасному світі апелює до поділу розвитку світу на вестфальский та поствестфальський. У традиційній кейнсіансько-вестфальській системі, яка розглядала сферою застосування справедливості лише державу в її кордонах, а суб'єктом відповідних громадян, усі явища, пов'язані з міжнародною діяльністю, залишалися ніби поза дією справедливості. Професор вважає, що це зумовило зосередження на так званих питаннях «про що» (наш курсив) справедливості, тобто про те, що вважається справедливим у стосунках між громадянами: формальна рівність перед законом, рівність можливостей, відкритий доступ до ресурсів, політична участь і т.д. Однак, як підкреслює автор, теорія справедливості, адекватна розв'язанню проблем в умовах глобалізуючого суспільства, має включати поряд 3 економічним виміром перерозподілу і культурним виміром визнання ще i політичний вимір представництва. 
Права людини в Україні та у зарубіжних країнах:

проблеми теорії та нормативно-правової регламентації

Останнє дозволяє поряд із питаннями «про що» обговорювати також питання «хто» і «як» (наш курсив) справедливості, тобто хто може висувати вимогу перерозподілу i визнання i як такі вимоги мають обговорюватися та вирішуватися. Це, на думку доповідача, означає парадигмальне зрушення в осмисленні справедливості, що ставить на місце кейсіанськовестфальської соціальної справедливості поствестфальську демократичну справедливість [11, с. 276].

У чому полягає справедливість у світовому масштабі? Справедливість як правова цінність $€$ багатоаспектним явищем. Як підкреслює С. Погребняк, завдячуючи роботі Дж. Ролза «Теорії справедливості» можна сьогодні проводити розрізнення між формальною, змістовною і процедурною справедливістю. Основна ідея формальної справедливості - до однакового слід ставитись однаково, що конкретизується у вимогах безсторонності та неупередженості. I тут формальна справедливість означає рівність перед законом, рівність перед судом, рівність прав, свобод і обов'язків людини і громадянина. Змістовна справедливість передбачає наявність певних принципів, які пояснюють, що ж конкретно належить кожному як учаснику суспільних відносин. Це має важливе значення у таких сферах як обмін, де справедливість важлива як еквівалентність (комутативна справедливість) та розподіл, коли кожна окрема людина $\epsilon$ причетною до спільного блага шляхом його справедливого розподілу (дистрибутивна справедливість). Процедурна справедливість можна визначити як чесне дотримання процедурних правил, що спрямовані на забезпечення справедливості результату тієї чи іншої дії незалежно від інших обставин [10]. Можливо припустити, що справедливість у цих трьох вимірах можна екстраполювати на глобальний масштаб у тій мірі, в якій справедливість виступає принципом організації людського співіснування, і сьогодні іiї вимоги досить виразно відображаються в основних постулатах, які покладені в основу глобальної справедливості. 
Аналіз матеріалів дозволяє зробити висновок про те, що глобальна справедливість більше фокусується на дистрибутивному аспекті принципу справедливості, особливо у контексті проблем бідності. Так, Т. Погґе послідовно відстоює думку про те, що наявний міжнародний інституційний порядок не справляється із задачею забезпечення справедливості, він акцентує увагу на тому, що у світі посилюється крайня бідність; міжнародна спільнота допускає прихід до влади корумпованих урядів в бідніших країнах, які отримують право продавати ресурси країни та розпоряджатися доходами від таких продажів, позичати кошти від імені країни і тим самим покладати на неї зобов'язання 3 обслуговування боргу, підписувати договори від імені країни і таким чином зв'язувати їі теперішнє та майбутнє населення, а також використовувати державні доходи для проведення політик внутрішніх репресій [29]. Проте, як демонструють інші дослідження проблем глобалізації та прав людини, що процесуальний зріз справедливості має важливе значення. Так, право людей на навколишнє середовище передбачає право мати доступ до повної інформації про потенційні наслідки небезпеки для навколишнього середовища, право брати участь у демократичних процедурах щодо формування кліматичної політики та права на скарги на існуючі умови [20].

Британський правник сучасності Д. Хелд систематизував основні вісім принципів, що $\epsilon$ формальним вираженням космополітичних цінностей і затверджують рівне значення кожної особистості в «моральній царині всього людства». Зазначені принципи і становлять, як вважає автор, основу космополітичного права, що доповнює національне й міжнародне право. Д. Хелд показує глобальну справедливість як спосіб представлення рівного морального становища всіх людей, їх домагання на рівну волю і форми правління, засновані на обговоренні і згоді [20]. Це такі принципи: 
1) рівні цінність і гідність;

2) активна дія;

3) персональні відповідальність і підзвітність;

4) згода;

5) колективне прийняття рішень з публічних питань за допомогою процедур голосування;

6) включеність і субсидіарність;

7) запобігання серйозній шкоді;

8) можливість підтримки.

Ці принципи, укладені майже 20 років тому, сьогодні зберігають свою актуальність, і міжнародні зусилля, спрямовані на їх дотримання, збагатили їх зміст та вибудували нові орієнтири. Варто визнати, що багато у чому ідея глобальної справедливості поглибилась концепцією сталого розвитку. Уперше поняття сталого розвитку було сформульовано у 1987 році у Звіті Комісії $\mathrm{OOH}$ під керівництвом Гро Харлем Брутланда, і ним позначався такий розвиток суспільства, який задовольняе потреби нинішніх поколінь і не ставить під загрозу можливості наступних поколінь задовольняти свої потреби» [21]. На той момент концепція сталого розвитку була заявлена як така, що здатна підтримувати економічний прогрес, забезпечуючи при цьому довгостроковий захист навколишнього середовища. Сьогодні 17 Цілей сталого розвитку (далі - ЦСР), затверджені світовим суспільством, передбачають 169 завдань, виконання яких передбачено у строк до 2030 року: боротьба з бідністю та голоду в усьому світі, 3 нерівністю всередині країн та між ними; захист права людини, захист природних ресурсів планети; створення умов для сталого, всеохоплюючого i безперервного економічного зростання, процвітання всього людства i гідної праці для всіх з урахуванням різних рівнів розвитку і спроможності країн [30]. Концепцію сталого розвитку світу називають своєрідною «формулою компромісу», адже ій передував інтенсивний тривалий міжнародний переговорний процес, зміст якої повинен бути 
актуальними та застосовним у майбутньому, а також набула сенсу «регуляторної ідеї» [27].

Соціальна справедливість, як підкреслюється в дослідженнях, є невід'ємною частиною концепції сталого розвитку. Більше того, вважається також, що сталий розвиток багато у чому виходить за межі ліберальних теорій справедливості, які не враховують таких позицій, як 1) прискорення екологічної взаємозалежності, 2) несправедливість у використанні ресурсів та 3) «розширення меж» («growth of limits»). I саме це створює конфлікт між справедливістю між та серед поколінь, а концепція сталого розвитку намагається на ці виклики реагувати, чого не може концепція справедливості, (наприклад, це робиться шляхом накладення мита на розвинені країни, що виходить за рамки ліберальних вимог) [26].

Інтерес дослідників глобальної справедливості дійсно значним чином прикутий до проблем навколишнього середовища та кліматичних проблем, адже боротьба зі змінами клімату потребує спільних зусиль, що передбачає потребу в глобальних угодах, що зможе визначити відповідальних суб'єктів, які несуть відповідальність за допомогу тим, хто зазнає непропорційно тяжких наслідків від змін клімату, що $є$ питанням дистрибутивної справедливості. Зміна клімату найбільш негативно впливає на тих, хто живе у менш розвинених країнах, які зробили найменший внесок у причини зміни клімату, і навпаки - ті, хто живе у розвинених країнах, які зробили найбільше викидів, зазнають менше негативних наслідків [20].

Скажімо, ЦСР 13 спрямована на боротьбу із змінами клімату та подолання його наслідків, передбачає такі інструменти реагування:

- створення відповідних політик та стратегій на національному рівні (13.2);

- створення передумов, зокрема, освітніх та інформаційних, для посилення можливостей людей та установ щодо пом'якшення гостроти та послаблення 
наслідків зміни клімату, адаптації до них і раннього попередження (13.3);

- «виконання взятих на себе зобов'язань розвиненими країнами, які є учасниками Рамкової конвенції Організації Об'єднаних Націй про зміну клімату, зобов'язання досягти мети щорічної мобілізації до 2020 року загальними зусиллями 100 млрд дол. США 3 усіх джерел для задоволення потреб країн, що розвиваються, в контексті прийняття конструктивних заходів щодо пом'якшення гостроти наслідків зміни клімату та забезпечення прозорості їх здійснення, a також забезпечити повномасштабне функціонування Зеленого кліматичного фонду шляхом його капіталізації в найкоротші можливі терміни» (13.a);

- зміцнення спроможностей людей у найменш розвинених країнах і малих острівних державах, що розвиваються, приділяючи, зокрема, підвищену увагу жінкам, молоді, а також місцевим і маргіналізованим громадам (13.b) [18].

Звичайно, «кліматичний» порядок денний - один із ряду напрямів, які $\epsilon$ однаково важливими та взаємопов'язаними між собою, виконання ключових завдань по яким сприятиме відповіді на ті виклики глобальної справедливості, які $\epsilon$ найбільш нагальними. Як видно, концепція сталого розвитку намагається ще більше акцентувати увагу не лише на справедливості всередині нині існуючого покоління (intragenerational justice) подолання бідності, голоду забезпечення рівності у сфері зайнятості, подолання гендерної нерівності, забезпечення повного доступу до правосуддя, але і справедливості щодо наступних поколінь (intergenerational justice) - раціональне використання природних ресурсів та пильна увага до проблем клімату.

Варте особливої уваги те, що Порядок денний сталого розвитку зосередив значну увагу на тому, що недержавні суб'єкти по всьому світу, а саме бізнес, транснаціональні компанії, несуть відповідальність у сфері прав людини. 
Хоча, справедливо відзначити, що ця ідея отримала своє втілення раніше у Глобальному договорі ООН - всесвітній ініціативі, заснованій у 2000 році, спрямованій на сприяння соціальній відповідальності бізнесу та підтримці вирішення підприємницькими колами проблем глобалізації та створення більш стабільної та всеохоплюючої економіки. Але нині ця ініціатива багато у чому сприяє досягненню ЦСР. На сьогоднішній день існує більше ніж 3800 компаній, що стали учасниками Глобального Договору, та 47 національних мереж Глобального Договору. Глобальний Договір відстоює принципи соціальної відповідальності бізнесу з особливою увагою, спрямованою на досягнення цілей ООН у 4 основних сферах, зокрема, прав людини; трудових відносин; навколишнього середовища та боротьби 3 корупцією. Десять принципів, вміщених у Глобальному договорі Організації Об’єднаних Націй походять із: Загальної декларації прав людини, Декларації Міжнародної організації праці про основні принципи та права на виробництві, Декларації Ріо про навколишнє середовище та розвиток, та Конвенції ООН проти корупції. Ці принципи проголошують наступне:

1) підприємства повинні підтримувати i поважати захист міжнародно проголошених прав людини та 2) постійно перевіряти, що вони не $\epsilon$ співучасниками порушень прав людини;

3) підприємства повинні підтримувати свободу асоціацій та ефективне визнання права на колективні переговори;

4) підприємства повинні дотримуватись абсолютної заборони всіх форм примусової праці 5) а також заборони використовувати дитячу працю;

6) підприємства повинні усувати дискримінацію щодо зайнятості та професії;

7) підприємства повинні підтримувати запобіжний підхід до екологічних проблем; 
8) підприємства повинні здійснювати ініціативи щодо сприяння більшій екологічній відповідальності і

9) заохочувати розвиток та розповсюдження екологічно чистих технологій;

10) підприємства повинні боротися проти корупції у всіх її формах, включаючи вимагання та хабарництво [22].

До речі, варто відзначити, що учасники Глобального Договору ООН сформулювали своє особливе звернення для керівництва бізнесом у відповідь на кризу, викликану пандемією вірусу COVID-2019 та нагадали про важливість дотримання прав людини у цей складний період. Зокрема, вони закликають забезпечувати доступ до засобів захисту від вірусної інфекції усім без дискримінації, відповідати гнучкістю робочих умов, зберігати за можливості заробітну платню, максимально можливою мірою забезпечити виконання контрактів, сприяти дистанційній роботі, забезпечувати гігієну та безпеку робочого місця.

Варто додати, що через 11 років після прийняття Глобального договору Радою ООН із прав людини у 2011 року було ухвалено ще один документ, присвячений бізнесу i правам людини - Керівні принципи ООН щодо бізнесу та прав людини, які грунтуються на визнанні не тільки зобов'язань держави щодо поваги, захисту та реалізації прав людини й фундаментальних свобод; але і ролі бізнес-структур як спеціалізованих органів суспільства, на які покладено виконання спеціальних функцій і до яких висувається вимога діяти відповідно до усіх застосовних законів і дотримуватися прав людини. При цьому невід'ємне значення мають передбачення в національному праві та корпоративних правилах відповідних й ефективних засобів правового захисту для усіх, хто зазнав порушень прав з боку бізнесу. Ці Керівні принципи застосовуються до всіх держав та до всіх бізнес-підприємств, як транснаціональних, так і інших, незалежно від їх розміру, сектора, місцезнаходження, форми власності та структури. У самому документі вказано, що вони 
сприяють посиленню стандартів і практик у сфері бізнесу i прав людини 3 тим, щоб окремі особи й громади, чиї інтереси зачіпаються, могли досягати вимірювальних результатів, і в цьому аспекті тлумачити їх як внесок у забезпечення соціально стійкої глобалізації.

\section{Висновки}

Незважаючи на те, що ст. 28 Загальної декларації прав людини не проголошує конкретного субстантивного права, вона має надзвичайно важливе смислоутворююче значення для Загальної декларації та для глобального правозахисного механізму. Формулювання цієї статті дало поштовх для постійного критичного осмислення існуючого глобального порядку. Фокус на людині як основній цінності та важливість розвитку міжнародних, зокрема економічних відносин, змусив наукову думку та світове товариство розмірковувати над тим, як відшукати консенсус між збереженням цінності прав людини та розвитком міжнародної кооперації. Теорія глобальної справедливості стала належною відповіддю на такий запит, а ст. 28 як нормативне існування глобальної справедливості виступає нагадуванням для всіх про те, що сьогодні повна реалізація прав людини неможлива без врахування національного та міжнародного контекстів. Права людини та їх повне й ефективне забезпечення продовжують залишатись мірилом міжнародних політик та ініціатив. Тільки ретельна обачність з урахуванням справедливості та ідеї прав людини зможе вибудовувати чи трансформувати міжнародні практики та норми, щоб забезпечувати довгостроковий ефект корисних та належних рішень.

\section{Список використаних джерел:}

1. Венская декларация и Программа действий, Принята на Всемирной конференции по правам человека 25 июня 1993 г. в Вене. URL: https://zakon.rada.gov.ua/laws/ show/995_504. 
Права людини в Україні та у зарубіжних країнах:

проблеми теорії та нормативно-правової регламентації

2. Гібернау M. Національна ідентичність vs космополітична ідентичність. Незалежний культурологічний часопис. URL: http://www.jimagazine.lviv.ua/2016/ Gibernau_Nacionalna_identychnist.htm.

3. Гороть Є.I. Великий англо-український словник. Вінниця : Нова кн. ; Харків : Ранок, 2011.

4. Декларація про принципи міжнародного права, що стосуються дружніх відносин і співробітництва між державами відповідно до Статуту Організації Об’єднаних Націй, прийнята резолюцією 2625 (XXV) Генеральної Асамблеї ООН від 24 жовтня 1970 року. URL: https://zakon.rada.gov.ua/laws/show/995_569.

5. Сендс Ф. Східно-Західна вулиця: повернення до Львова / Пер. з англ. Мигаль П. Вид-во Старого Лева. Львів, 2017.

6. Доповідь Генерального секретаря «Глобалізація та ії вплив на здійснення в повному обсязі всіх прав людини», 31 серпня 2000.

7. Задорожній О.В. Поняття та нормативні вимоги основних принципів міжнародного права. Актуальні проблеми держави і права. 2015. Вип. 75. С. 242-255.

8. Київець О.В. Загальні принципи права як джерело міжнародного права: природно-правовий та позитивістські підходи. Вісник Маріупольського державного університету. Сер. : Право. 2013. Вип. 5. С. 141-148.

9. Коллер П. Сфера значущості прав людини / Філософія прав людини. за редакції Ш. Госепата, Г. Ломанна ; Пер. 3 нім. О. Юдіна та Л. Доронічевої. Київ : Ніка-Центр, 2008. C. 15-32, 87-129.

10. Ломанн Г., Госепат Ш. Вступ. Загальна декларація прав людини - політичний вплив i потреба у філософському проясненні. Філософія прав людини / за редакції Ш. Госепата, Г. Ломанна ; пер. 3 нім. О. Юдіна та Л. Доронічевої. Київ : Ніка-Центр, 2008. С. 15-32.

11. Максимов С.I. Право і справедливість у глобальному суспільстві: XXII Всесвітній конгрес з філософії права i 
соціальної філософії. Вісник Академії правових наук України. Вісник Академії правових наук України. № 4(47). С. 276.

12. Погґе Т. Права людини як моральні вимоги до глобальних інституцій. Філософія прав людини / за редакції Ш. Госепата, Г. Ломанна ; пер. 3 нім. О. Юдіна та Л. Доронічевої. Київ : Ніка-Центр, 2008.

13. Погребняк С. Особливості втілення в праві різних аспектів справедливості. Вісник Академії правових наук України. № 1(52). Харків : Право, 2008. С. 31-42.

14. Філософія прав людини / за редакції Ш. Госепата, Г. Ломанна ; пер. $з$ нім. О. Юдіна та Л. Доронічевої. Київ : Ніка-Центр, 2008.

15. Світовий маніфест правового гуманізму. Загальна декларація прав людини як основа міжнародного та національного правозахисту : монографія / Рабінович П.М., Наконечна А.М., Добрянський С.П. та ін. Праці Львівської лабораторії прав людини і громадянина Науково-дослідного інституту державного будівнищтва та місцевого самоврядування Національної академії правових наук України. Львів : БФ «Медицина і право», 2018. Вип. 33. 180 с. (Сер. I. Дослідження та реферати).

16. Філософія права : підруч.для студ. юрид. вищ. навч. закл. / О.Г. Данильян, О.П. Дзьобань, C.I. Максимов та ін. ; За ред. д-ра філос. наук, проф. О.Г. Данильяна. Харків : Право, 2009.

17. Христова Г.О. Доктрина позитивних зобов'язань держави у сфері прав людини : дис. ... докт. юридичних наук : 12.00 .01 ; НЮУ ім. Ярослава Мдурого, Міністерство освіти і науки України, 2019. 492 с.

18. Ціль 13. Вжиття невідкладних заходів щодо боротьби зі зміною клімату та його наслідками / Цілі сталого розвитку. URL: http://sdg.org.ua/ua/pro-hlobalnitsili/climate-action\#глобальні-завдання.

19. Annual Activity Report 2019, presented to the Committee of Ministers and the Parliamentary Assembly / Commissioner for Human Rights of the Council of Europe, 
Dunja Mijatović (Strasbourg, 21 April 2020). URL: https://rm.coe.int/annual-activity-report-2019-by-dunjamijatovic-council-of-europe-commi/16809e2117

20. Dietzel A. Introducing Global Justice in International RelationsTheory. URL: https://www.e-ir.info/2018/01/02/ global-justice-in-international-relations-theory/

21. Emas R. "The Concept of Sustainable Development: Definition and Defining Principles", Brief for GSDR 2015, accessed August 20, 2019. URL: https://sustainabledevelopment.un.org/content/documents/5 839GSDR\%202015_SD_concept_definiton_rev.pdf.

22. Global Compact. United Nations. URL: https://www.unglobalcompact.org.

23. Globalisation. КОМПАС : Посібник з освіти в області прав людини за участі молоді. URL: https://www.coe.int/ uk/web/compass/globalisation\#7.

24. Held D. 'Law of States, Law of Peoples: Three Models of Sovereignty' in Legal Theory. 8. 2002. URL: http://www.lse.ac.uk/globalGovernance/publications/articles AndLectures/lawsOfStatesLawsOfPeoples.pdf.

25. Josh Curtis, Shane Darcy. The right to a social and international order for the realisation of human rights: article 28 of the universal declaration and international cooperation / in David Keane and Yvonne McDermott (eds.), The Challenge of Human Rights : Past, Present and Future, Edward Elgar Publishing, 2012. P. 8.

26. Langhelle, Oluf. "Sustainable Development and Social Justice: Expanding the Rawlsian Framework of Global Justice". Environmental Values 9, no. 3 (2000): 127-52. doi: $10.3197 / 096327100129342074$.

27. Michelsen, G. "Sustainable Development - Background and Context" in Sustainability Science: An Introduction. ed.Heinrichs, H., et al. (Dordrecht: Springer.; 2013).

28. Orsini Amandine. Lessons learnt from Coronavirus and global environmental challenges. OUPblog (April 15th 2020). URL: https://blog.oup.com/2020/04/lessons-learnt-fromcoronavirus-and-global-environmental-challenges/. 
Права людини в Україні та у зарубіжних країнах:

29. Pogge T. Poverty and Human Rights. URL: https://www2.ohchr.org/english/issues/poverty/expert/docs/ Thomas_Pogge_Summary.pdf.

30. Resolution adopted by the General Assembly on 25 September, 2015 Transforming our world: the 2030 Agenda for Sustainable Development. URL: https://www.un.org/en/ development/desa/population/migration/generalassembly/do cs/globalcompact/A_RES_70_1_E.pdf.

31. Understanding Human Rights: An Overview. by O.P. Dhiman. Kalpaz Publications, 2011. 392 p.

32. Widdows, H. (2011). What is global ethics? In Global Ethics: An Introduction (pp. 1-12). Acumen Publishing. doi:10.1017/UPO9781844652839.001. 
Права людини в Україні та у зарубіжних країнах:

проблеми теорії та нормативно-правової регламентації

DOI https://doi.org/10.36059/978-966-397-210-7/306-327

Міхальов В. О.,

доцент кафедри конституційного права

Національного університету «Одеська юридична академія»,

м. Odeca

\section{КОНСТИТУЦЙНІ ПРИНЦИПИ, ЗАБОРОНИ І ГАРАНТІЇ ЯК ЕЛЕМЕНТИ ПРАВОВОГО СТАНОВИЩА ОСОБИСТОСТІ}

Анотація. У цій науковій роботі розглядаються принципи, заборони та гарантії, які закріплені в Конституції України $i$ стосуються прав $i$ свобод особистості. Ці принципи характеризуються як ієрархічно побудована система, до складу якої входять три групи принципів. Першу групу принципів принципи конституційного ладу подано як систему загально соціальних гарантій, яка становить фундамент правового становища особистості. Запропоновано розподіл цих принципів на десять груп за певними підставами. Другу групу утворюють власне принципи правового становища особистості, які поділено на три групи. Третя група складається із принципів виборчого права. Заборони проаналізовані як спосіб правового регулювання, що знаходиться в нерозривному діалектичному зв'язку зі свободою, яка розглядається в якості принципу правового положення особистості і якості його гарантій. Юридичні гарантії у вигляді прав-гарантій, гарантій-заборон, та гарантії-обов'язку поділено на дві групи: гарантії реалізації та захисту прав і свобод особистості та гарантії, що виникають у питаннях, пов'язаних із притягненням людини до юридичної відповідальності.

\section{Вступ}

Останнім часом досить часто можна почути 3 вуст відносно великої частини політиків, політологів, соціологів, інших представників соціальних наук і навіть юристів, не кажучи вже про «простих» людей, про необхідність прийняття нової конституції, або внесення в 
чинну конституцію кардинальних змін. У першу чергу йдеться про реконструкцію юридичній організації держави, про вибір іншої форми правління, іншого територіального устрою, збільшення (зменшення) повноважень тих чи інших органів держави, засновування нових органів, союз і навіть приєднання до тих чи інших держав або державних об'єднань, тобто йдеться про владу та нові політичні, економічні, соціальні, ідеологічні орієнтири нової влади. Разом із тим нерідко згадують і про права людини, про необхідність модернізації, переробки і цих положень чинної Конституції України. Здається, що ці «модернізатори» не дуже ретельно ії читали чи не читали ії взагалі, що вони не знають або знають дуже приблизно про Загальну декларацію прав людини ООН, про міжнародні пакти про права людини, про Конвенцію Ради Європи про захист прав людини і основоположних свобод, про інші численні міжнародно-правові акти із приводу прав людини, що Україна приєдналась до абсолютної більшості цих документів, що порівняльний аналіз положень Конституції України із цими міжнародними актами показує, що на нормативному рівні в Україні запроваджені міжнародні стандарти прав людини.

Безумовно, життя не стоїть на місці, часто виникають нові виклики, в тому числі ті, що стосуються прав людини, i реагувати на них необхідно, проте відмовлятися від того, що вже напрацьовано, не можна. Головна проблема полягає в тому, що треба ретельно вивчати Основний Закон країни і запроваджувати в життя його положення, а серед тих положень, які стосуються прав людини, $є$ і те, на що не звертають увагу. Йдеться про такі елементи правового становища особистості, як принципи ії правового статусу, заборони певного виду діяльності, гарантії прав і свобод. Якщо вони не працюють, якщо на них не звертають уваги, то прав і свобод в особистості в державі не буде. Часто читач конституції пробігає ці положення поглядом, мовляв я це і так все добро знаю, тут немає нічого нового для мене. 
Права людини в Україні та у зарубіжних країнах:

проблеми теорії та нормативно-правової регламентації

\section{1. Правове становище особистості. Принципи конституційного ладу і принципи} правового становища особистості

Для визначення місця людини в системі соціальних зв'язків доцільно використовувати досить складну категорію - «правове становище особистості», центральним елементом якої $\epsilon$ категорія «правовий статус особистості» як система прав, свобод і обов'язків. В якості основних елементів, які передують цій системі, зумовлюють її, виступають: громадянські і правові статуси особистості, правоздатність та принципи правового становища особистості. Необхідно виділити і елементи, на яких вона базується. Це - загально-соціальні та спеціальні (юридичні) гарантії прав і свобод, як умови і засоби їх реалізації та захисту, без яких вони втрачають свій сенс, виступають як порожня нічим не підкріплена декларація.

Більшість вчених-конституціоналістів ототожнює поняття «конституційно-правове становище особистості» $\mathrm{i}$ «конституційно-правовий статус особистості». Дійсно, в перекладі 3 латинської мови термін «статус» зазвичай перекладається на українську як «становище». Проте розмежування цих термінів і надання кожному 3 них власного змісту підкреслює в терміні «конституційний статус особистості», права, свободи та обов'язки, що визначає місце людини в суспільстві і державі, в системі соціальних зв'язків. Разом із тим у межах більш широкого за обсягом терміна «правове становище особистості» з'являється можливість показати чинники, які зумовлюють той чи інший перелік прав, обов'язків, відповідальності у той чи іншій особи і ще підкреслити загальні і юридичні гарантії, які сприяють реалізації та захисту прав і свобод.

До того ж у Великому тлумачному словнику сучасної української мови поняття «становище» трактується як:

1. Ті чи інші обставини, умови, в яких хто-, що-небуть перебуває // Сукупність обставин, що створюють ту чи іншу ситуацію. 
2. Сукупність суспільно-політичних відносин, аспектів суспільного життя.

3. Місце, роль у суспільстві, в соціальному чи професійному середовищі, в сім'ї і. т. ін.

А поняття «статус» тлумачиться як:

1. У міжнародному праві - становище, стан // Певний стан чого-небудь.

2. Сукупність прав i обов'язків громадянина чи юридичної особи [1, с. 890, 895]. Отже, про повну тотожність цих термінів тут йдеться.

Уявляється, що саме термін «становище» більш доречний для того, щоби в одному понятті була показана в якості головного елементу сукупність прав і обов'язків, тобто правовий статус, а разом із тим показані інші обставини, аспекти життя, що створюють певну ситуацію, зумовлюють цей правовий статус.

Одним із головних елементів правового становища особистості є принципи.

Принципи права виконують роль початкових, визначальних ідей, які складають моральну та організаційну основу виникнення, розвитку і функціонування права. Вплив принципів на правовий статус вельми багатогранний. Саме принципи, їх реалізація свідчать про рівень забезпечення прав і свобод людини і громадянина. За ними можна судити про те, чи достатньо активна діяльність органів державної влади і місцевого самоврядування 3 дотримання та охорони прав і свобод особистості, що закріплені в Конституції та законах, чи існують будь-які межі в реалізації прав і свобод, чи допускаються їхні обмеження, чи функціонують законні механізми захисту прав особистості. Вони визначають основні риси статусу всіх членів суспільства, розповсюджуються на всі без виключення права, свободи і обов'язки, незалежно від того, якою галуззю права вони встановлені.

Характеризуючи структуру сучасної конституції, Т.Я. Хабрієва та В.Є. Чіркін пишуть, що «...перша глава сучасної конституції повинна бути присвячена суспільству, 
основним принципам цього найбільш широкого поняття, 3 яким людина нерозривно пов'язана. Людина, різні колективи, держава - все це існує і діє у суспільстві. Ця глава могла б називатися «Основи...» [2, с. 118]. У цій главі (розділу, частині) можна було б зафіксувати основні принципи економічної, соціальної, політичної системи, духовного життя суспільства ... У цій же главі важливо відобразити найважливіші положення про природу держави (демократична, соціальне і т.д.), як невід'ємної частини сучасного суспільства» [2, с. 119].

Фактично тут йдеться про основи будови суспільства i побудови держави, про сукупність принципів, на підставі яких повинні базуватися основоположні «конструкції» держави, які прямо або опосередковано стосуються правового становища особистості i завдають певний орієнтир їхньої деталізації безпосередньо в правах, свободах i обов'язках людини i громадянина. Але одночасно ці принципи виступають в якості загальносоціальних гарантій прав і свобод, оскільки «гарантії прав людини і громадянина - це умови і засоби, принципи та норми (курсив мій), які забезпечують здійснення, охорону і захист проголошених в конституції і законах прав і свобод» [3, с. 246]. У широкому розумінні «гарантії прав людини охоплюють всю сукупність об'єктивних і суб'єктивних факторів, що спрямовані на повну реалізацію і всебічну охорону і захист прав і свобод особистості, на усунення можливих причин та перешкод їх нездійснення» [4, с. 263].

Саме таким чином побудовано перший розділ чинної Конституції України.

Конституції належить особлива роль у встановленні принципів правового становища особистості. Ці принципи $\epsilon$ вихідними не тільки для визначення конституційного, а i в цілому загального правового статусу особистості. Основний Закон встановив більшість із цих принципів у чітких формулюваннях, що позитивно впливає на правове положення людини і громадянина. 
Конституційні принципи, що стосуються правового становища особистості, можна поділити на три групи, які пов'язані ієрархічним зв'язком.

Першу групу утворюють принципи основ конституційного ладу, які закріплені в Розділі I Основного Закону України. Вони встановлюють систему загальних (політичних, економічних, соціальних, культурних, та інших) гарантій правового становища особистості.

Уважно читаючи першій розділ Конституції України, можна побачити такі складові частини першої групи конституційних принципів - принципів-гарантій, які фактично виступають в якості загальних гарантій прав i свобод людини і громадянина:

Принципи, що встановлюють соціальний $i$ громадянський статус людини та ії відносини з державою. (cm. cm. 3,4):

1. Принцип визнання людини, ï̈ життя і здоров’я, честі і гідності, недоторканності і безпеки найвищою соціальною цінністю в Україні.

2. Принцип визначення змісту і спрямованості діяльності держави через права людини та їх гарантії.

3. Принцип відповідальності держави перед людиною за свою діяльність.

4. Принцип заборони узурпувати державою, її органами, або посадовими особами права народу визначати i змінювати конституційний лад в Україні.

5. Принцип проголошення, утвердження і забезпечення прав людини головним обов'язком держави.

6. Принцип єдиного громадянства.

Принципи, що встановлюють основи державного будівництва

України. (cm. 2, 5, 6, 7):

1. Принцип унітаризму.

2. Принцип республіканізму.

3. Принцип народного суверенітету i принцип народовладдя. 
4. Принцип заборони будь-кому узурпувати державну владу.

5. Принцип закріплення виключно за народом права визначати і змінювати конституційний лад в Україні.

6. Принцип розподілу влади.

7. Принцип визнання і гарантування місцевого самоврядування.

Принципи, що закладають основи правової системи $i$ основ правового порядку в Україні. (cm. cm. 8, 9, 19):

1. Принцип верховенства права.

2. Принцип найвищої юридичної сили норм Конституції України.

3. Принципи прийняття законів та інших нормативноправових актів на основі Конституції України.

4. Принцип прямої дії норм конституції України.

5. Принцип закріплення умов дії в Україні міжнародних договорів.

6. Принцип правового порядку в Україні: ніхто не може бути примушений робити те, що не передбачено законодавством.

7. Принципи діяльності органів державної влади, органів місцевого самоврядування та їх посадових осіб.

Принципи, що забезпечують розвиток $i$ захист мови $i$ культури в Україні (cm. cm. 10, 11, 12):

1. Принцип забезпечення всебічного розвитку i функціонування української мови у всіх сферах суспільного життя на території України.

2. Принцип гарантування в Україні вільного розвитку, використання і використання і захисту російської і інших мов національних меншин України.

3. Принцип сприяння 3 боку держави розвиткові української нації, її історичної свідомості, традицій і культури.

4. Принцип сприяння 3 боку держави вивченню мов міжнародного спілкування.

5. Принцип сприяння з боку держави консолідації та розвиткові української нації, іï̈ історичної свідомості, 
традицій і культури, а також самобутності всіх корінних народів і національних меншин.

6. Принцип задоволення національно-культурних i мовних потреб українців, які проживають за межами держави.

Принципи, що гарантують право власності і право користування природними ресурсами. (cm.cm. 13, 14):

1. Принцип визнання землі, iї надр, атмосферного повітря, водних та інших природних ресурсів в межах території України об’єктами права власності Українського народу.

2. Принцип можливості громадян користуватися природними об'єктами права власності народу.

3. Принцип забов'язального характеру власності і заборони ії використання на шкоду людині і суспільству.

4. Принцип гарантування захисту прав усіх суб'єктів права власності і господарювання.

5. Принцип визнання землі основним національним багатством.

6. Принцип гарантування права власності на землю.

Принципи заборони будь-якої обов'язкової ідеології, цензури, та гарантування свободи політичної діяльності. (cm. 15):

1. Принцип засад суспільного життя в Україні.

2. Принцип заборони визнання будь-якої ідеології обов'язковою.

3. Принцип заборони цензури.

4. Принцип гарантування свободи політичної діяльності, не забороненої Конституцією i законами України.

Принципи, що гарантують екологічну безпеку. (cm. 16):

1. Принцип забезпечення екологічної безпеки i підтримання екологічної рівноваги на території України.

2. Принцип подолання наслідків Чорнобильської катастрофи.

3. Принцип збереження Українського народу як обов'язок держави. 
Права людини в Україні та у зарубіжних країнах:

проблеми теорії та нормативно-правової регламентації

Принципи, які пов'язані із захистом України (ст. 17):

1. Принцип захисту суверенітету та територіальної цілісності України як найважливіші функції держави.

2. Принципи, які закріплюють завдання Збройних Сил України і відповідних військових формувань та правоохоронних органів держави.

3. Принцип заборони використання Збройних Сил України і інших військових формувань для обмеження прав і свобод громадян або повалення конституційного ладу, усунення органів влади чи перешкоджання їх діяльності.

4. Принцип соціального захисту громадян України, які перебувають на службі у Збройних Силах України та в інших військових формуваннях, а також членів їхніх сімей.

5. Принцип заборони створення і функціонування будьяких збройних формувань, не передбачених законом.

6. Принцип заборони розташування на території України іноземних військових баз.

Принципи зовнішньополітичної діяльності України. (cm. 18):

1. Принцип спрямування зовнішньополітичної діяльності України на забезпечення їі національних інтересів і безпеки.

2. Принцип підтримання Україною мирного i взаємовигідного співробітництва із членами міжнародного співтовариства за загальновизнаними принципами i нормами міжнародного права.

Саме ці принципи за умов їх суворого дотримання i створюють сприятливі обставини в усіх основоположних сферах суспільного життя для забезпечення прав, свобод i інтересів людини, тому вони одночасно і виступають в якості їхніх загальних гарантій.

Закріплений у ст. 3 принцип визнання людини, іï життя і здоров'я, честі і гідності, недоторканності і безпеки найвищою соціальною цінністю виступає фундаментальною основою по відношенню до другої групи конституційних принципів, які стосуються правового становища особистості і виражені в Розділі II Конституції України, якій 
власно і починається із закріплення принципів правового статусу особистості.

1. Принципи, що закріплюють основні засади прав $i$ свобод особистості (cm.cm. 21, 22, 23, 51):

1) принцип вільності і рівності всіх людей в їхній гідності і правах;

2) принцип непорушності і невідчужуваності прав i свобод людини;

3) принцип невичерпності прав і свобод людини i громадянина тими правами і свободами, що закріплені в Конституції;

4) принцип гарантування конституційних прав і свобод і неможливості їх скасування;

5) принцип недопущення звуження змісту та обсягу існуючих прав і свобод під час прийняття нових законів або внесення змін до чинних законів;

6) принцип, що закріплює право людини на вільний розвиток своєї особистості, якщо при цьому не порушуються права і свободи інших людей;

7) принцип наявності в кожної людини обов'язків перед суспільством;

8) принцип охорони сім'ï, дитинства, материнства i батьківства.

2. Принципи, що закріплюють принцип рівноправності та особливі обставини, які з ним пов'язані(ст.ст. 24, 26, 51, 52, 63):

1) принцип рівності конституційних прав i свобод громадян;

2) принцип рівності перед законом;

3) принцип рівності усіх суб’єктів власності перед законом;

4) принцип заборони привілеїв чи обмежень за різними ознаками;

5) принцип рівності прав чоловіка і жінки;

6) принцип рівності подружжя у шлюбі;

7) принцип рівності прав іноземців і осіб без громадянства, які на законних підставах перебувають в 
Україні 3 громадянами України за винятками, встановленим Конституцією, законами чи міжнародними договорами України;

8) принцип рівності дітей у своїх правах;

9) принцип рівності прав засудженого з правами інших осіб, за винятком обмежень, які визначені законом i встановлені вироком суду.

3. Принципи, що стосуються громадянських і правових станів особистості (cm. 25):

1) принцип неможливості позбавити громадянина України громадянства і права змінити громадянство;

2) принцип заборони виганяти громадянина України за іï̈ межи або видавати його іншій державі;

3) принцип гарантування з боку держави піклування і захисту громадянам України, які перебувають за її межами;

4) принцип можливості надання іноземцям і особам без громадянства притулку.

На відміну від першої групи принципів, принципів основ конституційного ладу, які мають загальний характер і на які, у зв'язку із цим, нерідко не звертають особливої уваги, друга група принципів безпосередньо наближена до особистості i тому їі треба сприймати як принципи правового становища особистості.

Третя група принципів закріплена у статті 71 Конституції України, встановлює принципи загального, рівного, прямого виборчого права, вільності виборів і таємного голосування. Очевидно, що принципи вільності і рівності прав усіх людей (ст.21) $є$ базовими по відношенню до принципів вільності виборів, а також загального і рівного виборчого права відповідно.

Демократичні принципи правового положення особистості, права і свободи людини і громадянина, на яких вони базуються, а також гарантії їх реалізації та захисту знаходяться в тісному взаємозв'язку і $\epsilon$ основою для нормального існування людини. За думкою Н.В. Вітрука, принципи юридичної конструкції правового становища особистості $\epsilon$ «особливим, специфічним елементом...» який 
визначає «...сутність і зміст правового положення особистості та його структурних елементів». Вони «...складають теоретико-методологічний та правовий стрижень правового положення особистості...цементують, об'єднують в одне ціле комплекс структурних елементів правового положення особистості, надають філософськоідеологічне його обгрунтування» [5, с. 88].

\section{2. Конституційні принципи-заборони як спосіб правового регулювання}

Само правове становище особистості встановлюється за допомогою законодавчого закріплення уповноважуючих, зобов'язуючих або забороняючих правових норм, які визначають модель правомірної поведінки їхніх учасників. Цими нормами закріплені дозволяння, зобов'язання та заборони. Якщо звернутися до Конституції України, то можна виявити, що ні в найменуванні другого розділу «Права, свободи i обов'язки людини i громадянина», ні в найменуванні інших розділів заборони як способи впливу на суспільне життя не вказані зовсім, і складається уявлення, що вони в неї або взагалі відсутні, або законодавець не використовує цей термін, оскільки заборона в суспільній свідомості асоціюється негативно, як обмежування свободи. Між тим пильне ознайомлення з текстом Основного Закону України дозволяє побачити більше чотирьох десятків подібного роду установлень, і в першу чергу це стосується основ конституційного ладу, своєрідного фундаменту всієї правової системи України, які виступають передусім в якості бази основоположних начал правового становища особистості (Розділ 1 Конституції України) та власне основ правового становища особистості (Розділ 2 Конституції України). Якщо звернутися до Конституції України, то можна виявити, що ні в найменуванні другого розділу «Права, свободи i обов'язки людини i громадянина», ні в найменуванні інших розділів заборони як способи впливу на суспільне життя не вказані зовсім, і складається уявлення, що 
вони в неї або взагалі відсутні, або законодавець не використовує цей термін, оскільки заборона в суспільній свідомості асоціюється негативно, як обмежування свободи. Між тим пильне ознайомлення з текстом Основного Закону України дозволяє побачити більше чотирьох десятків подібного роду установлень, і в першу чергу це стосується основ конституційного ладу, своєрідного фундаменту всієї правової системи України, які виступають передусім в якості бази основоположних начал правового становища особистості (Розділ 1 Конституції України) та власне основ правового становища особистості (Розділ 2 Конституції України).

Зобов'язання та заборони розглядаються як дві близькі за суттю категорії. Проте якщо зобов'язання передбачає певне обтяження, що пов'язане з необхідністю виконання тої чи іншої дії, то заборона, навпаки, полягає в утриманні від вчинення встановленої в забороні дії. Водночас дозволяння і заборони на перший погляд виглядають як абсолютно несумісні один з одним методи в механізмі правового регулювання, що визначають систему прав i свобод. Проте заборона як спосіб правового регулювання знаходиться у нерозривному діалектичному зв'язку зі свободою, що розглядається в якості принципу правового положення особистості. Принцип свободи іноді розподіляють на дві складові: «свобода для...» та «свобода від...». Перша з них знаходить своє відображення, своє розгортання в системі позитивних потенційних можливостей для людини, які юридично виражаються через систему суб'єктивних прав, свобод i законних інтересів людини, а друга отримує свій розвиток в системі заборон від можливих несприятливих впливів на людину $з$ боку інших суб'єктів правовідносин: держави, групи осіб, окремих людей. Це певні «зони небезпеки», тобто такі області життя кожної людини, вторгнення в які для інших суб'єктів без їі добровільної згоди на це суперечить правам, свободам і інтересам даної особи, а тому неприпустиме, крім випадків, визначених законом, та які у зв'язку із цим 
Права людини в Україні та у зарубіжних країнах:

проблеми теорії та нормативно-правової регламентації

огороджені своєрідною «юридичною огорожею» заборонами. Вони органічно «уплетені» в систему прав та свобод особистості та охороняють людину від цих несприятливих для нього діянь.

Принципи конституційного ладу та принципи правового положення особистості, що закріплені в перших трьох розділах Конституції України, виражені як через позитивні визначення, наприклад, «людина, іiї життя i здоровя, честь і гідність, недоторканність і безпека визнаються в Україні найвищою соціальною цінністю», (ст. 3, ч. 1), так і через деякі заборони, наприклад: «Ніхто не може узурпувати державну владу» (ст. 5, ч. 4).

Досліджуючи дану проблематику, С.С. Алексєєв прийшов до висновку про те, що по певному колу питань «...принцип ...права не тільки слугує підставою для введення загальних заборон, але, по суті справи, вони злилися та виступають у вигляді єдиного принципазаборони» [6, с. 235].

Заборони в Конституції України закріплені за допомогою таких лексичних конструкцій: «право...не може...» (ст. 5, ч. 3), «ніхто не може...» (ст.ст. 5, ч. 4; 19, ч. 1 ; 27 , ч. $2 ; 28$, ч. $2 ; 29$, ч. $2 ; 32$, ч. $1 ; 35$, ч. $4 ; 36$, ч. $4 ; 41$, ч. $4 ; 44$, ч. $3 ; 47$, ч. $3 ; 54$, ч. $2 ; 58$, ч. $2 ; 61$, ч. 1 ), «...не повинна використовуватися...» (ст. 13,ч. 3), «...не може...» (ст. 15, ч. 2; ст. 24 , ч. 2 ; 25 ,ч. 2 ; 35,ч. 3; ст. 41, ч. 7; 49, ч. 3), «..заборонена» (ст. 15, ч. 3) «...не можуть бути використані...» (ст. 17, ч. 4), «...забороняється...» (ст. 17, ч. 6; ст. 43, ч. 3 ; 43, ч. 5), «...забороняються» (ст. 37,1$)$, «...не допускається...» (ст.ст. 17 , ч. $7 ; 22$, ч. $3 ; 30$, ч. $2 ; 32$, ч. $2 ; 37$, ч. 3 ; ст. 42 , ч. 3), «...не можуть бути скасовані» (ст. 22, ч. 2), «громадянин...не може...» (ст. 25, ч. 1, ч. 2; ст. 33, ч. 2), «жодна людина...не може...» (ст. 28, ч. 3), «...не можуть мати...» (ст. 37, ч. 2), «...ніким не може...» (ст. 50, ч. 2), «...переслідується за законом» (ст. 52, ч. 2), «...не можуть бути обмежені...» (ст. 64, ч. 1, ч.2) «не мають права...» (ст. 70, ч. 1).

Конституція України запроваджує такі заборони: 
- заборона на скасування конституційних прав і свобод (ст. 22, ч. 2);

- заборона на звуження змісту та обсягу наявних прав і свобод під час прийняття нових законів (ст. 22, ч. 3);

- заборона на існування привілеїв та обмежень за ознаками раси, кольору шкіри, політичних, релігійних та інших переконань, статі, етнічного та соціального походження, майнового стану, місця проживання, за мовними або іншими ознаками (ст. 24, ч. 2);

- заборона на позбавлення громадянина України громадянства і права змінити громадянство (ст. 25, ч. 1);

- заборона на вигнання громадянина України за межі України або видання іншій державі (с. 25, ч. 2);

- заборона на свавільне позбавлення людини життя (ст. 27, ч. 2);

- заборона на піддавання людини катуванню, жорстокому, нелюдському, або такому, що принижують його гідність, поводженню чи покаранню покаранню (ст. 28, ч. 2);

- заборона на піддавання людини без їі згоди медичним, науковим або іншим дослідам (ст. 28, ч. 3);

- заборона на арешт людини або утримання іï під вартою інакше як за вмотивованим рішенням суду і тільки на підставах та в порядку, встановлених законом. (ст. 29, ч. 2);

- заборона на проникнення до житла чи іншого володіння особи, проведення в них огляду чи обшуку інакше як за вмотивованим рішенням суду. (ст. 30, ч. 2);

- заборона на втручання в особисте і сімейне життя людини, крім випадків, передбачених Конституцією України (ст. 32, ч. 1);

- заборона на збір, зберігання, використання та поширення конфіденційної інформації про особу без ії згоди, крім випадків, визначених законом, і лише в інтересах національної безпеки, економічного добробуту та прав людини (ст. 32, ч. 2); 
- заборона на позбавлення громадянина України права в будь-який час повернутися в Україну (ст. 33, ч. 2);

- заборона на визнання державою жодної релігії як обов'язкової (ст. 35, ч. 3);

- заборона на увільнення людини від своїх обов'язків перед державою або відмовлення від виконання законів за мотивами релігійних переконань (ст. 35, ч. 4);

- заборона на примушення людини до вступу в будьяке об'єднання громадян чи обмеження у правах за належність чи неналежність до політичних партій або громадських організацій (ст. 36, ч. 4);

- заборона на утворення і діяльність політичних партій та громадських організацій, програмні цілі або дії яких спрямовані на ліквідацію незалежності України, змісту конституційного ладу насильницьким шляхом, порушення суверенітету і територіальної цілісності держави, підрив ії безпеки, незаконне захоплення влади, пропаганду війни, насильства, на розпалювання міжетнічної, расової, релігійної ворожнечі, посягання на права i свободи людини, здоров'я населення (ст. 37, ч. 1);

- заборона на наявність воєнізованих формувань у політичних партій та суспільних організацій (ст. 37, ч. 2);

- заборона на створення і діяльність організаційних структур політичних партій в органах виконавчої і судової влади i виконавчих органах місцевого самоврядування, військових формуваннях, а також на державних підприємствах, у навчальних закладах та інших державних установах і організаціях (ст. 37, ч. 3);

- заборона на протиправне позбавлення людини права власності (ст. 41, ч. 4);

- заборона на використання власності для завдання шкоди правам, свободам і гідності громадян, інтересам суспільства, погіршення екологічної ситуації та природної якості землі (ст. 41, ч. 7);

- заборона на зловживання монопольним становищем на ринку, неправомірне обмеження конкуренції та недобросовісну конкуренцію (ст. 42, ч. 3); 
Права людини в Україні та у зарубіжних країнах:

проблеми теорії та нормативно-правової регламентації

- заборона на використання примусової праці (ст. 43, ч. 3);

- заборона на використання праці жінок та неповнолітніх на небезпечних для їхнього здоров'я роботах (ст. 43 , ч. 5);

- заборона на примушення до участі або неучасті у страйку (ст. 44, ч. 3);

- заборона на примусове позбавлення житла інакше, як на підставі закону за рішенням суду (ст. 47, ч. 3);

- заборона на скорочення наявної мережі державних i комунальних закладів охорони здоров'я (ст. 49, ч. 3);

- заборона на засекречення інформації про стан довкілля, про якість харчових продуктів і предметів побуту (ст. 50, ч. 2);

- заборона на будь-яке насильство над дитиною та ії експлуатацію (ст. 52, ч. 2);

- заборона на використання i поширювання результатів інтелектуальної, творчої діяльності без згоди автора, за винятками, встановленими законом (ст. 54, ч. 2);

- заборона на відповідальність людини за дії, які під час їх вчинення не визнавалися законом як правопорушення (ст. 58, ч. 2);

- заборона на притягнення людини до юридичної відповідальності одного виду двічі за одне й те саме правопорушення (ст. 61, ч. 1);

- заборона на піддавання кримінальному покаранню особи за вчинення злочину, доки її вину не буде доведено в законному порядку і встановлено обвинувальним вироком суду (ст. 62, ч. 1);

- заборона на обвинувачення особи, яке грунтується на доказах, одержаних незаконним шляхом, а також на припущеннях (ст. 62, ч. 3);

- заборона на обмеження прав i свобод людини i громадянина, крім випадків, передбачених Конституцією України (ст. 64, ч. 1);

- заборона обмежувати права і свободи, передбачені статтями $24,25,27,28,29,40,47,51,52,55,56,57,58,59,60$, 61, 62, 63 Конституції України (ст. 64, ч. 2). 
У першому розділу Конституції України «Загальні засади» заборони-принципи закріплені в таких статтях: ст. 5 , ч. 3 ; ст. 5 ч. 4 ; ст. 13 , ч. 3 ; ст. 15 , ч. 2 ; ст. 15 , ч. 3 ; ст. 17 , ч. 4 ; ст. 17 , ч. 6 ; ст. 17 , ч. 7 ; ст. 19 , ч. 1.

Деякі із цих статей прямо звернені не до особистості, а до держави, ïï органів або посадових осіб чи до народу України. Проте, виходячи 3 ідеї одного із співавторів Декларації прав людини і громадянина 1789 р. абата Е.Ж. Сійєса, що «будь-який суспільний союз, і отже, будьяке політичне установлення може мати предметом лише проголошення, розповсюдження та забезпечення прав людини і громадянина» (цит. по [7, с. 117]), уявляється можливим включити їх у перелік заборон, які визначають основи правового становища особистості.

\section{3. Юридичні гарантії прав і свобод особистості}

У свій час К. Маркс писав, що «на бумазі легко можна прокламувати конституції, право кожного громадянина на освіту, на працю, і передусім на певний мінімум засобів існування. Але тим, що всі ці великодушні побажання записані на бумазі зроблено, ще не все: залишається ще одна задача запліднення цих ліберальних ідей матеріальними та розумними соціальними запровадженнями» (Цит. по: [8, с. 179]). Цю задачу закликані виконувати гарантії прав і свобод.

Гарантії прав людини і громадянина - це умови та засоби, що забезпечують можливість користуватися правами, які встановлені в конституції і законах держави. У широкому розумінні під поняттям «гарантії прав людини» розуміється сукупність об'єктивних та суб'єктивних факторів, які спрямовані на повну реалізацію та всебічну охорону прав і свобод особистості, на усунення можливих причин і обставин їх здійснення.

Більшість гарантій у вигляді умов спрямовані на забезпечення сприятливої обстановки, в атмосфері якої громадянин може ефективно користуватися своїми конституційними правами і свободами. Такі умови створюють зовнішнє середовище діяльності кожної людини і 
не залежать від його волі і побажань, оскільки вони іманентно притаманні суспільному і державному ладу.

Усі гарантії прав людини поділяють на загальні (загально-соціальні) та спеціальні (юридичні). Загальні гарантії - це система ідеологічних, економічних, політичних, духовних та інших відносин, умов, факторів, що задекларовані в основному законі, без яких вимоги особистості до суспільства носили би суто формальний характер (про них йшлося у \&1). Спеціальні (юридичні) гарантії - це встановлені державою 3 наданням їм формальної (юридичної) обов'язковості принципи і норми, які забезпечують здійснення зазначених прав і свобод шляхом належної регламентації порядку їх здійснення, а також їх охорони і захисту.

Найбільший за кількістю статей (21-68) другий розділ Конституції України «Права, свободи і обов’язки людини і громадянина», незважаючи на назву, містить у собі й інші елементи правового становища особистості, а саме його принципи, заборони i юридичні гарантії, притому останнім присвячено не лише окремі статті (принципи встановлено статтями 21-26, а юридичним гарантіям відведено статті 55-64). Ці гарантії можна знайти у других за рахунком i наступних частинах відповідних статей, які закріплюють те чи інше основне право. За невеликим винятком майже у всіх статтях, в яких закріплено права і свободи особистості, закріплені і їхні гарантії. При цьому нерідко буває, що один вз елементів тісно пов'язаний 3 іншим, i тоді для того, щоб підкреслити наявність присутності кожного 3 них, можуть використовуватися подвійні назви: принципи-гарантії, принципи-заборони; гарантії-заборони, права-гарантії, гарантії-обов'язки тощо.

Юридичні гарантії прав і свобод людини і громадянина, що закріплені у другому розділі Конституції України, можуть бути поділені на дві групи.

1. Юридичні гарантії реалізації та захисту конституційних прав і свобод особистості:

- право знати свої права і обов'язки (ст. 57, ч. 1); 
- право на судовий захист прав та свобод людини i громадянина (ст. 55, ч. 1);

- право на оскарження в суді рішень, дій чи бездіяльності органів державної влади, органів місцевого самоврядування, посадових і службових осіб (ст. 55, ч. 2);

- право на звернення за захистом своїх прав до Уповноваженого Верховної Ради України з прав людини (ст. 55, ч. 3);

- право на звернення за захистом своїх прав із конституційною скаргою до Конституційного Суду України з підстав, встановлених Конституцією України, в порядку, визначеному законом (ст. 55, ч. 4);

- право після використання всіх національних засобів юридичного захисту звертатися за захистом своїх прав і свобод до відповідних міжнародних судових установ чи до відповідних органів міжнародних організацій, членом або учасником яких є Україна (ст. 55, ч. 5) ;

- право будь-якими не забороненими законом засобами захищати свої права і свободи від порушень та протиправних посягань (ст. 55, ч. 6);

- право на відшкодування за рахунок держави чи органів місцевого самоврядування матеріальної та моральної шкоди, завданої незаконними рішеннями, діями, або бездіяльністю органів державної влади, органів місцевого самоврядування, їхніх посадових і службових осіб під час здійснення ними своїх повноважень (ст. 56);

- обов'язок держави довести закони та інші нормативно-правові акти, що визначають права і обов'язки громадян, до відома населення в порядку, встановленому законом (ст. 57, ч. 2).

- право на професійну правничу допомогу і свободу вибору захисника своїх прав (ст. 59);

- заборона обмеження конституційних прав і свобод, крім випадків, передбачених Конституцією України (ст. 64, ч. 1).

2. Права-гарантії, та гарантії-заборони, що виникають у питаннях, пов'язаних із притягненням людини до юридичної відповідальності: 
- заборона зворотної дії законів та інших нормативноправових актів у часі, крім випадків, коли вони пом'якшують або скасовують відповідальність особи (ст. 58, ч. 1);

- заборона відповідати за діяння, які на час їх вчинення не визнавалися законом як правопорушення (ст. 58, ч. 2);

- право не виконувати явно злочинне розпорядження чи накази (ст. 60, ч. 1);

- заборона бути двічі притягнутим до юридичної відповідальності одного виду за одне й те саме правопорушення (ст. 61, ч.1);

- право на презумпцію невинуватості (ст. 62, ч. 1);

- заборона будь-кому доводити свою невинуватість у вчиненні злочину (ст. 62, ч. 2);

- заборона грунтувати обвинувачення на доказах, одержаних незаконним шляхом, а також на припущеннях (ст. 62, ч. 3)

- право в разі вироку суду як неправосудного відшкодування державою матеріальної і моральної шкоди, завданої безпідставним засудженням;

- право підозрюваного, обвинуваченого чи підсудного на захист (ст. 62, ст. 4);

- право не давати показання або пояснення щодо себе, членів сім'ї чи близьких родичів (ст. 63, ч. 1).

- право підозрюваного, обвинуваченого чи підсудного на захист (ст. 63, ч. 2).

\section{Висновки}

Як і в кожній системі, у правовому становищі особистості всі елементи, які її складають, не тільки тісно пов'язані між собою, взаємно доповнюють один одного, але разом із тим кожний із низ має своє призначення, виконує певну функцію. Принципи, заборони та гарантії правового становища не можна розглядати як другорядні елементи цієї системи, кожен із них одночасно виступає і у власній «ролі», і має ознаки іншої. Так, принципи несуть у собі не лише заряд визначальних ідей, але й гарантій прав i свобод, а інколи вони виражені через заборони. Заборони в системі прав і свобод особистості виступають у вигляді 
гарантій певних прав, забороняють такі моделі поведінки людини, які несумісні із правопорядком, зі справедливістю, із правами та свободами інших членів суспільства, а юридичні гарантії нерідко закріплені в Конституції як права.

Дотримання принципів конституційного ладу i принципів правового становища особистості, виконання вимог закону щодо заборон та гарантій стане надійним фундаментом для забезпечення прав і свобод людини і громадянина.

\section{Список використаних джерел:}

1. Великий тлумачний словник сучасний словник сучасної української мови. Київ : Ірпень : ВТФ «Перун», 2001. 1440 c.

2. Хабриева Т.Я., Чиркин В.Е. Теория современной конституции. Москва : Норма, 2005. 320 с.

3. Рабінович П.М., Хавронюк М.I. Права людини і громадянина : навч. посібник. Київ : Атіка, 2004. 464 с.

4. Головистикова А.Н., Грудцына Л.Ю. Права человека. Москва : Эксмо, 2008. 448 с.

5. Витрук Н.В. Основы теории правового положения личности. Москва : Норма, 2008. 488 с.

6. Алексеев С.С. Общие дозволения и общие запреты в советском праве. Москва : Юрид.лит., 1989. 288 с.

7. Конституция в XX1 веке: сравнительно-правовое исследование. Москва : Норма: ИНФРА-М, 2011. 655 с.

8. Тодика Ю.Н., Тодыка О.Ю. Конституционно-правовой статус человека и гражданина в Украине. Киев : Концерн «Видавничий дім «Ін Юре», 2004. 368 с. 
Права людини в Україні та у зарубіжних країнах:

проблеми теорії та нормативно-правової регламентації

DOI https://doi.org/10.36059/978-966-397-210-7/328-348

Полішук Н. Р.,

кандидат юридичних наук, асистент кафедри теорії та історії держави і права

Національного університету біоресурсів

і природокористування України,

м. Kuїв

\section{ПРАВО НА ОСВІТУ ОСІБ З ОСОБЛИВИМИ ОСВІТНІМИ ПОТРЕБАМИ}

Анотація. Визнання прав осіб з особливими освітніми потребами, їхніх інтересів, потреб, надання допомоги у процесі соціалізації та вибору професійної діяльності є надзвичайно важливими для розвитку сучасної системи освіти. Однією із складових гуманітарної політики найбільш розвинених країн світу є успішне впровадження інклюзивної освіти. Оскільки популяризація інклюзії в суспільних відносинах свідчить, наскільки держава захищає невід'ємні права людини. Україна як вагома частина європейського простору поступово входить $в$ оновлений освітній процес, що враховує світові стандарти освіти. Важливим $\epsilon$ дослідження правового регулювання відносин, що виникають у процесі інклюзивного навчання. Це стосується $i$ осіб з особливими освітніми потребами, $i$ закладів освіти та інших державних інституцій, які беруть участь в організації та контролі за дотриманням норм в процесі інклюзивного навчання.

\section{Вступ}

у статті 26 Загальної декларації прав людини, проголошеної ООН 10 грудня 1948 року, закріплено право на освіту, яке належить до другого покоління прав і свобод людини і громадянина. Освіта відіграє найважливішу роль для всебічного розвитку людини як особистості, їі талантів, розумових і фізичних здібностей, виховання високих моральних якостей, здобуття професійних 
навичок та їх удосконалення. Неможливо не виділити цінності ролі освіти в розбудові державних інститутів та суспільства, оскільки саме вона $є$ основою їх розвитку в інтелектуальній, культурній, духовній, соціальній та економічній сферах. Відповідно, якість і рівень освіти напряму впливають на прогрес держави і суспільства.

Підписання Угоди про асоціацію України з ЄС $\epsilon$ безпосереднім юридичним фактом для виникнення спільних відносин у галузі міжнародної політики, економіки, освіти, науки, культури тощо. Відповідно, перед нашою державою постала нагальна потреба запровадити нововведення, що спрямовані на застосування європейських стандартів освіти та наближення вітчизняної системи освіти до загальноєвропейського освітнього рівня. Усе це передбачає покращення якості знань, запровадження інноваційних технологій, удосконалення системи організації навчального процесу й оцінювання якості знань. Також реформування освіти в Україні спрямоване на вирішення питання забезпечення рівного вільного доступу до освіти усіх членів суспільства. Право на освіту закріплено в Основному законі України (стаття 53) та включає у себе право здобувати освіту впродовж усього життя, право на доступність освіти, право на безоплатну освіту у випадках і порядку, визначених Конституцією та законами України. Також право на освіту гарантується незалежно від віку, статі, раси, стану здоров'я, інвалідності, громадянства, національності, політичних, релігійних чи інших переконань, кольору шкіри, місця проживання, мови спілкування, походження, соціального і майнового стану, наявності судимості, а також інших обставин та ознак(стаття 3 Закону України «Про освіту» від 5 вересня 2017 року).

Прийняття Закону України «Про освіту» від 5 вересня 2017 року та Закону України «Про внесення змін до деяких законів України щодо доступу осіб з особливими освітніми потребами до освітніх послуг» 6 вересня 2018 року стало важливим кроком для наближення української системи 
освіти до європейських стандартів рівності та доступності освіти. Адже цими нормативно-правовими актами закріплено правове регулювання освітніх послуг для осіб з особливими освітніми потребами.

\section{1. Виникнення та розвиток інклюзивної освіти у світі та Україні}

Світові процеси глобалізації, гуманізації та демократизації безпосередньо впливають на модернізацію освітніх систем, що першочергово проявляється в поступовому переході традиційної моделі освіти до інклюзивної. Проте так було не завжди, і для усвідомлення важливості та необхідності впровадження інклюзивного навчання було пройдено декілька історичних етапів.

Видатними вченими в галузі педагогіки Колупаєвою А.А., Таранченко О.M. виділено такі періоди становлення інклюзивної освіти у світі:

- перший період (996-1715 рр.) - від агресії та зневаги до усвідомлення необхідності піклуватися про людей із відхиленнями в розвитку. У Німеччині відкирвається перший притулок для сліпих (1198 р);

- другий період (1715-1806 рр.) - від усвідомлення необхідності піклуватися про осіб із відхиленнями в розвитку до усвідомлення навчати частину з них. У Франції відкриваються спеціальні школи для глухонімих і сліпих (1770-1784 pp.);

- третій період (1806-1927 рр.) - від усвідомлення можливостей до усвідомлення доцільності навчати три категорії дітей: із порушеннями слуху, зору та розумово відсталих. Здійснюється прийняття в західноєвропейських державах законів про загальну початкову освіту і на цій основі - законів про навчання глухих, сліпих і розумово відсталих дітей.

- четвертий період (1927-1991рр.) - від усвідомлення необхідності навчання певної частини дітей із порушеннями до розуміння необхідності навчати всіх дітей 
із відхиленнями в розвитку. У країнах Західної Європи ухвалюються антидискримінаційні законодавчі акти, що затверджуються 3 урахуванням основних положень Декларацій ООН.

- п’ятий період (1991 р. - й донині) - від сегрегативного навчання дітей з особливими освітніми потребами до інклюзивної освіти. У Західній Європі з кінця 70-х років значно скорочується кількість спеціальних шкіл, збільшується кількість спеціальних класів у загальноосвітніх школах, учнів з особливими освітніми потребами починають навчати в загальноосвітніх школах в інклюзивному середовищі [1, с. 10-13].

Розвитку інклюзивного навчання сприяло прийняття низки міжнародних нормативно-правових актів, якими закріплено ключові цінності під час використання права на освіту, а саме рівності, доступності, недискримінації. Цей шлях транформації системи освіти можна періодизувати за прийнятими міжнародними документами.

1. Загальна декларація прав людини (1948) - закріпила право людини на освіту, яка має бути безоплатною (початкова та загальна) i обов'язковою (початкова), загальнодоступною (технічна і професійна), рівно доступною (вища), має сприяти взаєморозумінню, терпимості і дружбі між усіма народами, расовими або релігійними групами[2].

2. Конвенція про боротьбу з дискримінацією в галузі освіти (1960) визначила поняття «дискримінація» як відмінність, виняток, обмеження або перевагу за ознакою раси, кольору шкіри, статі, мови, релігії, політичних або інших переконань, національного або соціального походження, економічного становища або місця народження, що має на меті (або наслідком якої є) знищення чи порушення рівності у сфері освіти [3].

3. Міжнародний пакт про економічні, соціальні i культурні права (1966) - передбачено право кожної людини на обов'язкову та безоплатну початкову освіту, 
а також поступовий перехід до безоплатної середньої і вищої освіти [4].

4. Конвенція про права дитини (1989) - закріплено, що освіта $€$ самоцінною і визнається найголовнішим правом кожної особи, а держави визнають право дитини на освіту 3 метою поступової реалізації цього права на основі надання рівних можливостей, визначено, що неповноцінна в розумовому або фізичному відношенні дитина має вести повноцінне і достойне життя в умовах, які забезпечують ії гідність, сприяють почуттю впевненості в собі та полегшують іï активну участь у житті, неповноцінна дитина має право на ефективний доступ до послуг у сфері освіти, професійної підготовки, медичного обслуговування, відновлення здоров'я, підготовки до трудової діяльності і доступу до засобів відпочинку, що призводить до найбільш повного залучення дитини в соціальне життя та досягнення розвитку її особистості, включаючи культурний і духовний розвиток дитини [5].

5. Всесвітня декларація про освіту для всіх (1990) визначено необхідність загального доступу до навчання, сприяння забезпеченню рівності, збільшення засобів i масштабів базової освіти, покращення умов для освіти та зміцнення партнерських зв'язків, забезпечення рівного доступу до освіти осіб 3 інвалідністю як невіддільної частини системи освіти [6].

6. Стандартні правила забезпечення рівних можливостей для осіб з інвалідністю (1993) - визначено принципи рівних можливостей у сфері початкової, середньої і вищої освіти для дітей, молоді і дорослих, які мають інвалідність, зазначено, що освіта осіб 3 інвалідністю $\epsilon$ обов'язковою і невіддільною частиною системи загальної освіти, а держава має забезпечити гнучкість освітніх програм, надавати високоякісні навчальні матеріали, покращити підготовку педагогічних працівників[7].

7. Саламанська декларація (1994) - вперше введено поняття інклюзивного навчання, інклюзивної школи та 
особливих освітніх потреб. Визначено, що школи повинні приймати всіх дітей, незважаючи на їхні фізичні, інтелектуальні, соціальні, емоційні, мовленнєві або інші особливості, освітні заклади мають шукати шляхи успішного навчання всіх дітей, включаючи дітей, у яких $\epsilon$ серйозні порушення розвитку та інвалідність, закріплено основні принципи інклюзивної школи, які полягають у тому, що всі діти повинні навчатися разом у будь-яких випадках, коли це $\epsilon$ можливим, незважаючи ні на які труднощі або відмінності, що існують між ними, а зарахування дітей у спеціальні школи чи класи має бути винятком, рекомендованим тільки в тих рідкісних випадках, коли абсолютно очевидним $є$ те, що навчання у звичайних класах не здатне задовільнити освітні чи соціальні потреби будь-якої дитини або якщо це необхідно для благополуччя цієї дитини чи інших дітей. Закріплено, що розвиток інклюзивних шкіл як найефективніший засіб забезпечення освітою всіх необхідно визнати основним напрямом державної політики i виділити його як пріоритет у програмах розвитку країни [8].

8. Копенгагенська декларація про соціальний розвиток (1995) - визначено, що держави мають сприяти доступу дітей до закладів освіти і забезпечити якість освіти 3 метою усунення нерівності, пов'язаної із соціальними умовами, і відмінностей за ознакою раси, національного походження, статі, віку або інвалідності [9].

9. Дакарські рамки дій (2000) - наголошено на необхідності створення безпечних, здорових, інклюзивних умов у сфері освіти, що сприяють успішному навчанню [10].

10. Конвенція ООН про права осіб 3 інвалідністю (2006) - визнано право осіб з інвалідністю на освіту, забезпечення інклюзивної освіти на всіх рівнях упродовж усього життя, неможливість виключення осіб через їхню інвалідність із системи загальної освіти, а дітей 3 інвалідністю - із системи безоплатної та обов'язкової початкової або середньої освіти, забезпечення розумного пристосування, що враховує індивідуальні потреби, 
отримання всередині системи загальної освіти необхідної підтримки для полегшення ефективного навчання [11].

11. Інчхонська декларація (2015) - наголошено на необхідності забезпечити інклюзивну та якісну освіту на рівноправній основі, надати кожній людині можливість здобувати освіту впродовж усього життя [12].

Система освіти для осіб 3 певними порушеннями розвитку в Україні розвивалась поетапно від окремих спроб індивідуального навчання, організації групового навчання і до створення окремих навчальних закладів. Науковцями виокремлено кілька періодів становлення системи освіти осіб з порушеннями розвитку в Україні:

I період (X - перша половина XIX ст.) - період формування системи церковної благодійності в закладах при цервах і монастирях.

II період (перша половина XIX - початок XX ст.) - період філантропічного благочинництва та відкриття перших приватних закладів для різних категорій дітей 3 порушеннями розвитку.

III період (до 30-х років XX ст.) - період законодавчонормативного та організаційного оформлення системи освіти осіб 3 порушеннями розвитку; оформлення діагностичних підходів та відповідної практики відбору дітей до закладів освіти.

IV період (30-50-ті роки XX ст.) - період загальносоюзної уніфікації освіти; оформлення спеціальної системи освіти осіб 3 порушеннями розвитку; науково-теоретичне обгрунтування диференційованого навчання різних категорій дітей із порушеннями та практичне впровадження їх у відповідних закладах освіти.

V період (50-90-ті роки XX ст.) - період удосконалення та розширення мережі закладів системи спеціальної освіти; наукове вдосконалення підходів, 3 урахуванням нових технічних досягнень.

VI період (90-ті роки XX ст.- сучасність) - період розбудови національної системи освіти; перегляд концептуальних підходів щодо освіти осіб із порушеннями 
розвитку у відповідності із законодавчими актами міжнародного рівня та враховуючи соціальні зміни в суспільстві; впровадження інклюзивної практики [1, с. 14].

\section{2. Нормативно-правове забезпечення}

\section{права на інклюзивну освіту}

Після ратифікації Верховною Радою України Конвенції ООН про права осіб з інвалідністю 16.12.2009 року наша держава взяла на себе зобов'язання забезпечити реалізацію прав осіб з інвалідністю, зокрема їхнє право на освіту. Як наслідок до закону України «Про загальну середню освіту» були внесені зміни, згідно з якими діти 3 особливими освітніми потребами отримали можливість здобувати загальну середню освіту дистанційно або в спеціальних чи інклюзивних класах. Крім того, для виконання положень конвенції було прийнято низку нормативно-правових актів, зокрема:

1. Розпорядження КМУ «Про затвердження плану заходів щодо запровадження інклюзивного та інтегрованого навчання у загальноосвітніх закладах на період до 2012 року»;

2. Постанова КМУ «Про затвердження Порядку організації інклюзивного навчання»;

3. Наказ МОН України «Про затвердження Концепції розвитку інклюзивного навчання»;

4. Наказ МОН України «Про організацію інклюзивного навчання у загальноосвітніх навчальних закладах».

Варто зазначити, що прийняття зазначених актів не сприяло системному впровадженню інклюзивного навчання, а його реальний розвиток розпочався із ухвалення закону України від 23.05.2017 року «Про внесення змін до Закону України «Про освіту» щодо особливостей доступу осіб 3 особливими освітніми потребами до освітніх послуг». Адже саме ці зміни торкнулися реалізації права осіб з особливими освітніми потребами, передбачили зобов'язання закладів загальної середньої освіти за зверненням представників осіб 3 
особливими освітніми потребами створювати інклюзивні класи, надання гарантій на отримання психологопедагогічних, корекційно-розвивальних послуг, навчання за допомогою найбільш доступних для таких осіб мови, методів спілкування.

Міністерством освіти і науки України було затверджено «Примірне положення про команду психолого-педагогічного супроводу дитини 3 особливими освітніми потребами в закладі загальної середньої та дошкільної освіти». Цим положенням врегульовано внутрішній процес організації інклюзивного навчання, передбачено команду психолого-педагогічного супроводу, яка включає в себе директора чи заступника директора з навчально-виховної роботи, вчителя початкових класів або класного керівника, вчителів, асистентів вчителя, практичного психолога, соціального педагога, вчителя-дефектолога, вчителяреабілітолога, працівника інклюзивно-ресурсного центру та батьків чи законних представників дитини. Крім того, для організації інклюзивного навчання осіб з особливими освітніми потребами в закладах середньої освіти введено посаду асистента вчителя на клас [13]. Також встановлено доплату в розмірі двадцяти відсотків від заробітної плати педагогічним працівникам та помічникам вихователів закладів освіти за роботу в інклюзивних класах [14].

У Концепції розвитку інклюзивної освіти визначено основні принципи інклюзивної освіти:

- науковість (розроблення теоретико-методологічних основ інклюзивного навчання, програмно-методичного інструментарію, аналіз і моніторинг результатів упровадження інклюзивного навчання, оцінка ефективності технологій, що використовуються для досягнення позитивного результату, проведення незалежної експертизи);

- системність (забезпечення рівного доступу до якісної освіти дітей 3 особливими освітніми потребами, наступності між рівнями освіти: рання допомога дошкільна освіта - загальна середня освіта); 
- варіативність, корекційна спрямованість (організація особистісно-орієнтованого навчального процесу у комплексі 3 корекційно-розвитковою роботою для задоволення соціально-освітніх потреб, створення умов для соціально-трудової реабілітації, інтеграції в суспільство дітей із порушеннями психофізичного розвитку, у тому числі дітей-інвалідів);

- індивідуалізація (здійснення особистісно-орієнтованого індивідуального, диференційованого підходу);

- соціальна відповідальність сім'ї (виховання, навчання і розвиток дитини; створення належних умов для розвитку їі природних здібностей, участь у навчальнореабілітаційному процесі);

- міжвідомча інтеграція та соціальне партнерство (координація дій різних відомств, соціальних інституцій, служб із метою оптимізації процесу освітньої інтеграції дітей з особливими освітніми потребами) [15].

Загалом стану законодавства у сфері інклюзивної освіти в Україні характерні такі риси:

1. Гарантування рівного доступу до якісної освіти дітей з особливими освітніми потребами, права вибору різних типів закладів освіти і форм навчання.

2. Розширення практики інклюзивної освіти в закладах дошкільної, загальної середньої, позашкільної, професійної (професійно-технічної) і вищої освіти.

3. Реформування системи шкіл-інтернатів i забезпечення навчання дітей за місцем їх проживання.

4. Зростання уваги до своєчасної комплексної психолого-педагогічної оцінки розвитку дитини і надання їй психолого-педагогічних, корекційно-розвиткових послуг.

5. Індивідуаліція освітнього процесу шляхом розробки індивідуальної програми розвитку і здійснення особистісно орієнтованого (індивідуального, диференційованого) навчання.

6. Введення у штати закладів освіти посади вчителівдефектологів, ставки асистента вчителя. 
7. Міжвідомча інтеграція та соціальне партнерство (залучення батьків і представників різних відомств, соціальних інституцій, служб з метою оптимізації процесу освітньої інтеграції дітей 3 особливими освітніми потребами [16, с. 27].

\section{3. Правове регулювання інклюзивного навчання у сфері освітніх послуг}

Ратифікувавши основні міжнародні правові документи щодо права дітей з особливими освітніми потребами на рівний доступ до якісної освіти, Україна почала впроваджувати інклюзивне навчання в національну систему освіти, закріпивши це в низці нормативноправових актів.

Одним із найважливіших кроків для реалізації принципів інклюзивної освіти стало прийняття закону України «Про освіту». Саме цим законом визначено поняття інклюзивного навчання як системи освітніх послуг, гарантованих державою, що базується на принципах недискримінації, врахування багатоманітності людини, ефективного залучення та включення до освітнього процесу всіх його учасників. Серед засад державної політики в освітній сфері виділено також ті, що безпосередньо зв'язані із принципами інклюзивної освіти загалом. Це забезпечення рівного доступу до освіти без дискримінації за будь-якими ознаками, в тому числі за ознакою інвалідності, розвиток інклюзивного освітнього середовища, в тому числі в закладах освіти, найбільш доступних i наближених до місця проживання осіб 3 особливими освітніми потребами, та забезпечення універсального дизайну та розумного пристосування.

Із метою наближення принципів інклюзивного навчання в Україні до світових стандартів у законодавстві було введено поняття особи 3 особливими освітніми потребами, якою $є$ особа, що потребує додаткової постійної чи тимчасової підтримки в освітньому процесі з метою 
забезпечення їі права на освіту[17]. А законом України «Про вищу освіту» особу 3 особливими освітніми потребами визначено як особу з інвалідністю, яка потребує додаткової підтримки для забезпечення здобуття вищої освіти [18]. Законодавством України роз'яснено поняття особи з інвалідністю як особи зі стійким розладом функцій організму, що під час взаємодії із зовнішнім середовищем може призводити до обмеження її життєдіяльності, внаслідок чого держава зобов'язана створити умови для реалізації нею прав нарівні 3 іншими громадянами та забезпечити іiї соціальний захист [19]. Проте визначення закону України «Про вищу освіту» особи з особливими освітніми потребами суперечить п. 1 ст. 19 закону України «Про освіту», в якому зазначено, що органи державної влади та органи місцевого самоврядування створюють умови для забезпечення прав i можливостей осіб 3 особливими освітніми потребами для здобуття ними освіти на всіх рівнях освіти 3 урахуванням їхніх індивідуальних потреб, можливостей, здібностей та інтересів. Суперечність полягає в тому, що у особа 3 інвалідністю належить до однієї з багатьох категорій у переліку категорій осіб з особливими освітніми потребами.

Так категорії осіб з особливими освітніми потребами визначаються актами Кабінету Міністрів України 3 урахуванням міжнародних норм і стандартів. Кабмін у Постанові № 952 від 14.11.2018 року «Про деякі категорії осіб з особливими освітніми потребами» визначив, що до категорії осіб $з$ особливими освітніми потребами, які потребують розумного пристосування для проходження зовнішнього незалежного оцінювання, належать особи, які здобувають (здобували) повну загальну середню освіту мовою, що не належить до слов'янської групи мов, особи, які здобувають (здобували) повну загальну середню освіту мовою корінних народів [20].

До прийняття Постанови КМУ № 952 від 14.11.2018 року Міністерством освіти і науки України було розроблено та запропоновано для громадського обговорення проект 
Постанови «Про затвердження Переліку деяких категорій осіб з особливими освітніми потребами». У цьому акті визначено перелік осіб з особливими освітніми потребами, до якого належать:

- особи з порушеннями зору, слуху, опорно-рухового апарата; хворобами нервової системи; затримкою психічного розвитку, інтелектуальними порушеннями, складними порушеннями мовлення (в тому числі 3 дислексією);

- іншими складними порушеннями розвитку (в тому числі з розладами спектру аутизму);

- особи, яким встановлено електрокардіо-стимулятор або інший електронний імплантат чи пристрій;

- особи, які мають захворювання, що можуть бути перешкодою для проходження зовнішнього незалежного оцінювання, визначені МОН спільно з МО3;

- особи, які мають захворювання, що потребують постійного медичного нагляду, або періодичного здійснення індивідуальних медичних процедур із забезпечення життєдіяльності людини та/або контролю за її станом;

- особи, які потребують відновлення стану здоров'я в закладах загальної середньої освіти санаторного типу;

- особи, які опинились у складних життєвих обставинах, влаштовані до дитячих будинків сімейного типу, соціально-реабілітаційних центрів, перебувають у школах соціальної реабілітації;

- особи, які проживають на тимчасово окупованій території або в населених пунктах, на території яких органи державної влади тимчасово не здійснюють свої повноваження, або в населених пунктах, що розташовані на лінії зіткнення;

- особи, які мають статус внутрішньо переміщених;

- діти-біженці та діти, які потребують додаткового та тимчасового захисту;

- особи, які здобувають спеціалізовану освіту та/або можуть прискорено опанувати зміст навчальних предметів одного чи декількох класів, освітніх рівнів; 
- особи, які здобувають(ли) повну загальну середню освіту мовою, що не належить до слов'янської групи мов, або базову чи профільну середню освіту - мовою корінних народів (особи 3 особливими мовними освітніми потребами).

Проаналізувавши вище вказані нормативно-правові акти, оцінюючи суттєву відмінність у них, можемо зробити висновок, що i досі в Україні не визначено на законодавчому рівні перелік категорій осіб з особливими освітніми потребами. Дана прогалина в законодавстві обмежує можливість певних категорій населення на користування своїм конституційним правом на освіту. Хоча законом «Про освіту» передбачено, що заклади освіти в обов'язковому порядку утворюють інклюзивні та/або спеціальні групи і класи для навчання осіб з особливими освітніми потребами у разі їхнього звернення. Проте на практиці виникає проблема, що освітні заклади не охоче реагують на такі звернення, оскільки законом не передбачений конкретний перелік осіб 3 особливими освітніми потребами, а це дозволяє їм відсилати цих осіб чи їхніх законних представників у різні установи для доказування своєї належності до такої категорії.

У пункті 4 Наказу Міністерства освіти і науки України від 16.04.2018 № 367, зареєстрованого в Міністерстві юстиції України 05 травня 2018 р. за № 564/32016 «Про затвердження Порядку зарахування, відрахування та переведення учнів до державних та комунальних закладів освіти для здобуття повної загальної середньої освіти» вказано, що зарахування до закладу освіти здійснюється відповідно до наказу його керівника, що видається на підставі заяви про зарахування до закладу освіти (далі заява про зарахування) одного 3 батьків дитини (чи повнолітньої особи, яка має намір здобувати освіту), поданої особисто (із пред'явленням документа, що посвідчує особу заявника). У цьому ж порядку чітко вказано, які саме документи мають додати до заяви батьки (законні представники дитини). Серед переліку документів 
$\epsilon$ Висновок про комплексну (чи повторну) психологопедагогічну оцінку розвитку дитини чи витягу з протоколу засідання психолого-медико-педагогічної консультації, а висновок лікарсько-консультативної комісії закладу охорони здоров'я не може бути підставою для організації інклюзивного навчання для дитини 3 особливими освітніми потребами.

Висновок про комплексну (чи повторну) психологопедагогічну оцінку розвитку дитини, яка має особливі освітні потреби, роблять спеціалісти 3 найближчого до місця проживання дитини інклюзивно-ресурсного центру. Інклюзивно-ресурсний центр є установою, що утворюється 3 метою забезпечення права дітей з особливими освітніми потребами віком від 2 до 18 років на здобуття дошкільної та загальної середньої освіти, в тому числі в закладах професійної (професійно-технічної) освіти та інших закладах освіти, які забезпечують здобуття загальної середньої освіти, шляхом проведення комплексної психолого-педагогічної оцінки розвитку дитини (далі комплексна оцінка), надання психолого-педагогічних, корекційно-розвиткових послуг та забезпечення їх системного кваліфікованого супроводу [21].

Команда супроводу особи 3 особливими освітніми потребами впродовж двох тижнів 3 моменту початку освітнього процесу складає індивідуальну програму розвитку на основі висновку інклюзивно-ресурсного центру, індивідуальної програми реабілітації дитини 3 інвалідністю (за наявності), результатів психо-педагогічного вивчення дитини. Індивідуальна програма розвитку подається для погодження батькам чи законним представникам особи з особливими освітніми потребами, а після цього затверджується керівником освітнього закладу. Після затвердження індивідуальна програма розвитку переглядається двічі на рік у закладах загальної середньої освіти, а в закладах дошкільної освіти - тричі на рік.

Способи адаптації освітнього середовища та навчальні матеріали визначаються командою супроводу відповідно 
до потенційних можливосте та 3 урахуванням індивідуальних особливостей дитини [22].

Загалом право на освіту не може бути обмеженим і тому будь-яка особа може навчатися в закладах освіти усіх рівнів і ступенів. Особи з особливими освітніми потребами мають таке беззаперечне право і можуть ним скористатись, подавши відповідне звернення до обраного нею навчального закладу. Проте в системі освіти передбачені і спеціальні заклади освіти, в яких виховуються або навчаються виключно діти 3 особливими освітніми потребами. До них належать:

Заклади дошкільної освіти для дітей 3 особливими освітніми потребами:

1) ясла-садок компенсуючого типу (для дітей 3 особливими освітніми потребами віком від двох до семи (восьми) років, поділяються на спеціальні та санаторні);

2) будинок дитини (для медико-соціального захисту дітей-сиріт і дітей, позбавлених батьківського піклування, а також для дітей з фізичними та (або) інтелектуальними порушеннями від народження до трьох (для здорових дітей) та до чотирьох (для хворих дітей) років);

3) ясла-садок комбінованого типу(для дітей віком від одного до шести (семи, восьми) років, у складі якого можуть бути групи загального розвитку, компенсуючого типу, інклюзивні, сімейні, прогулянкові, в яких забезпечується дошкільна освіта 3 урахуванням стану здоров'я дітей, їхнього розумового, психологічного, фізичного розвитку);

4) центр розвитку дитини (в якому забезпечуються фізичний, розумовий і психологічний розвиток, корекція психологічного і фізичного розвитку, оздоровлення дітей, які відвідують інші навчальні заклади чи виховуються вдома) [23].

Заклади загальної середньої освіти для осіб 3 особливими освітніми потребами:

1. Спеціальна школа (для дітей з порушеннями слуху; для дітей із порушеннями зору; для дітей із порушеннями 
опорно-рухового апарату; для дітей із порушеннями інтелектуального розвитку; для дітей із тяжкими порушеннями мовлення).

2. Навчально-реабілітаційний центр (для дітей, які мають порушення слуху в поєднанні 3 порушеннями інтелектуального розвитку та/або порушеннями опорнорухового апарату; для дітей, які мають порушення зору в поєднанні із тяжкими системними мовленнєвими порушеннями чи порушеннями інтелектуального розвитку та/або порушеннями опорно-рухового апарату, та сліпоглухих дітей; для дітей, які мають порушення опорнорухового апарату в поєднанні 3 тяжкими системними мовленнєвими порушеннями чи порушеннями інтелектуального розвитку; для дітей із порушеннями інтелектуального розвитку в поєднанні 3 тяжкими порушеннями мовлення) [24].

\section{Висновки}

Особи 3 особливими освітніми потребами можуть реалізувати своє конституційне право на освіту за різними моделями навчання. Науковцями виділено такі моделі:

- медична - передбачає сегрегаційне навчання дітей $з$ обмеженими можливостями здоров'я у спеціальних закладах інтернатного типу;

- нормалізаційна (інтеграційна) - забезпечує доступ дітей з обмеженими можливостями здоров'я до навчання в загальноосвітній школі з урахуванням їхньої адаптації до наявних у ній умов: інтегроване навчання в корекційних класах загальноосвітньої школи;

- соціальна (інклюзивна) - грунтується на зміні освітнього середовища таким чином, щоб воно забезпечувало рівну участь своїх громадян у здійсненні їх прав; створенні єдиного освітнього середовища для навчання дітей із різним рівнем психофізичного здоров'я, або інклюзивне навчання як включення дітей 3 особливими освітніми потребами у спільне навчання 3 дітьми нормативного розвитку у загальноосвітній школі. 
Остання модель навчання $є$ інноваційним підходом до навчання дітей з особливими освітніми потребами. Адже інклюзивна освіта передбачає модифікацію освітньої програми та освітнього середовища до потреб учнів, які відрізняються своїми навчальними можливостями. Інклюзія в освіті реалізується через такі кроки:

1) створення таких умов, за яких усі учні мають однаковий доступ до освіти, в тому числі діти 3 особливими освітніми потребами, які навчаються в загальноосвітніх школах;

2) надання можливості іншим учням отримати досвід, знання, які сприяють подоланню упереджень й дискримінації та сприяють формуванню позитивного ставлення до тих, хто «відрізняється».

Відзначаючи позитивні зміни, які відбулись у нашій державі у сфері надання освіти для осіб з особливими освітніми послугами за останнє десятиліття, не можна не підкреслити ті проблеми, які й досі залишаються:

- вітчизняна система освіти має високий рівень уніфікованості, що перешкоджає забезпеченню освітніх потреб усіх учнів, які мають особливості психофізичного розвитку, ускладнює впровадження різних навчальних програм та внесення необхідних змін та додатків до навчальних планів;

- діти з психофізичними порушеннями ізольовані в спеціальних школах-інтернатах, які сьогодні $є$ основними спеціальними освітніми закладами, а це спричиняє відокремлення сім'ї від виховного процесу та обмеженість розвитку у дітей інших життєвих компетенцій;

- недостатня соціально-практична спрямованість навчального процесу, наслідками якої $\epsilon$ : низький рівень сформованості соціально-побутової компетентності учнів, незадовільна орієнтація в системі соціальних норм і правил та відсутність навичок самостійної життєдіяльності;

- недостатня індивідуалізованість та особистісна зорієнтованість навчально-виховного процесу, наслідками якої $\epsilon$ труднощі емоційного та особистісного розвитку 
учнів, неадекватні уявлення про свої якості, здібності й можливості;

- низька ефективність корекційно-розвивальних занять, що зумовлює низький рівень комунікативної компетентності, замкнутості, ізольованості;

- відсутність ліцензійного психолого-педагогічного інструментарію для діагностики порушень, що ускладнює правильне комплектування спеціальних закладів й організацію відповідного навчання;

- недостатнє науково-методичне та навчальне забезпечення освітнього процесу дітей 3 важкими патологіями, атиповими порушеннями, що потребують додаткових освітніх та корекційно- реабілітаційних послуг [1, с. 33].

Інклюзивне навчання покликане до створення якісних змін в особистому розвитку дітей з особливими освітніми потребами, організації нового освітнього середовища, яке б відповідало потребам і можливостям кожної дитини, незалежно від особливостей ії психофізичного розвитку, сприяння позитивному клімату у шкільному середовищі та поза його межами.

\section{Список використаних джерел:}

1. «Інклюзивна освіта: від основ до практики» : монографія / А.А. Колупаєва, О.М. Таранченко. Київ : ТОВ «АТОПОЛ», 2016. 152 с. (Серія «Інклюзивна освіта»).

2. Загальна декларація прав людини від 10.12.1948. URL: https://zakon.rada.gov.ua/laws/show/995_015.

3. Конвенція про боротьбу з дискримінацією в галузі освіти 14 грудня 1960 року URL: https://zakon.rada.gov.ua/laws/show/995_174.

4. Міжнародний пакт про економічні, соціальні і культурні права. URL: https://zakon.rada.gov.ua/laws/ show/995_042.

5. Конвенція про права дитини 20 листопада 1989 року. URL: https://zakon.rada.gov.ua/laws/show/995_021.

6. Всесвітня декларація про освіту для всіх. URL: https://zakon.rada.gov.ua/laws/show/995_001-94. 
7. Стандартні правила забезпечення рівних можливостей для осіб з інвалідністю від 20 грудня 1993 року. URL: https://zakon.rada.gov.ua/laws/show/995_306.

8. Саламанська декларація. URL: https://zakon.rada.gov.ua/ laws/show/995_001-94.

9. Копенгагенська декларація про соціальний розвиток. URL: https://zakon.rada.gov.ua/laws/show/995_505.

10. Дакарські рамки дій. URL: https://www.un.org/ru/ events/literacy/dakar.htm.

11. Конвенція ОOH про права осіб з інвалідністю. URL: https://zakon.rada.gov.ua/laws/show/995_g71.

12. Інчхонська декларація. URL: https://pon.org.ua/ international/4171-inchxonska-deklaraciya-koncepciyarozvitku-osviti.html.

13. Наказ Міністерства освіти і науки України «Про внесення змін до наказу Міністерства освіти і науки України від 06 грудня 2010 року № 1205» № 90 від 01.02.2018. URL: https://zakon.rada.gov.ua/laws/show/ z0226-18.

14. Постанова Кабінету Міністрів України від 14.02.2018 № 72 «Про внесення змін у додаток до постанови Кабінету Міністрів України від 25 серпня 2004 р. № 1096». URL: https://zakon.rada.gov.ua/laws/show/722018-\%D0\%BF.

15. Наказ Міністерства освіти і науки України «Про затвердження концепції розвитку інклюзивного навчання» від 01.10.2010 № 912. URL: https://mon.gov.ua/ua/npa/prozatverdzhennya-kontseptsii-rozvitku-inklyuzivnogo-navchannya.

16. Порошенко М.А. Інклюзивна освіта : навчальний посібник. Київ : ТОВ «Агентство Україна», 2019. 300 с.

17. Закон України «Про освіту» від 5 вересня 2017 року № 2145-VIII. Відомості Верховної Ради (ВВР). 2017. № 38-39. Ст. 380.

18. Закон України «Про вищу освіту» від 1 липня 2014 року № 1556-VII. Відомості Верховної Ради (ВВР). 2014. № 37-38. Ст. 2004. 
19. Закон України «Про основи соціальної захищеності осіб з інвалідністю в Україні» від 21 березня 1991 року № 875-XII. Відомості Верховної Ради УРСР (ВВР). 1991. № 21. Ст. 252.

20. Постанова Кабінету Міністрів України «Про деякі категорії осіб 3 особливими освітніми потребами» від 14 листопада 2018 р. № 952. URL: https://zakon.rada.gov.ua/ laws/show/952-2018-\%D0\%BF.

21. Постанова Кабінету Міністрів України «Про затвердження Положення про інклюзивно-ресурсний центр» від 12 липня 2017 p. № 545. URL: https://zakon.rada.gov.ua/laws/show/545-2017-\%D0\%BF.

22. Додаток до листа МОН від 05.08.2019 № 1/9 498 «Методичні рекомендації щодо організації навчання осіб з особливими освітніми потребами в закладах освіти в 2019/2020 н. p.». URL: https://mon.gov.ua/storage/app/ media/inkluzyvne-navchannya/2019/08/07/rekomendatsii organizatsiya-navchannyaoop.pdf.

23. Закон України «Про дошкільну освіту» від 11 липня 2001 року № 2628-III. Відомості Верховної Ради України (BBP). 2001. № 49. Ст. 259.

24. Постанова Кабінету Міністрів України «Про затвердження Положення про спеціальну школу та Положення про навчально-реабілітаційний центр» від 6 березня 2019 р. № 221. URL: https://zakon.rada.gov.ua/ laws/show/221-2019-\%D0\%BF. 
Права людини в Україні та у зарубіжних країнах:

проблеми теорії та нормативно-правової регламентації

DOI https://doi.org/10.36059/978-966-397-210-7/349-368

Timofeyeva L. Yu., Candidate of Juridical Sciences, Assistant Professor of Criminal Law Department of the National University "Odessa Law Academy", Odesa

\title{
PROBLEMS OF HUMAN RIGHTS AND THEIR DEVELOPMENT IN THE CONDITIONS OF A CHANGING SOCIETY
}

\begin{abstract}
The work deals with some human rights problems and it development in Ukraine and in the world in the changing conditions. There are three generations of human rights: freedom, equality and solidarity. These rights are reflected in the Constitution of Ukraine, the Constitutions of the countries of the world, the Convention for the Protection of Human Rights and Fundamental Freedoms, as well as other international instruments.

At the same time, society is constantly evolving, and human rights are developing. The fourth generation of human rights has emerged with development. Some researchers also talk about the emergence of the fifth and sixth generation.

The paper argues that in modern conditions there are challenges related to ecology, gender, sexual orientation, religion, artificial intelligence etc. New forms of discrimination are justified.

In these circumstances, it was found that a balance must be struck between human rights and freedoms and the security of the state.
\end{abstract}

\section{Introduction}

The concept of the «three generations» of human rights was introduced by K. Vasak in 1977. The author identified the following three generations of human rights: the rights of liberty, the rights of equality and the rights of solidarity [15].

These rights are reflected in the Constitution of Ukraine, the Constitutions of the countries of the world, the Convention for 
the Protection of Human Rights and Fundamental Freedoms, as well as other international instruments.

Constitutionalists have devoted their work to human rights issues, including: M.P. Orzikh, P.L. Rabinowicz and others. A number of domestic and foreign scientists and scientists, including M.I. Kozyubra, S.B. Buletsa, M.M. Oleinik are dealing with the latest human rights issues.

At the same time, society is constantly evolving, and human rights are developing, which determines the relevance of the research topic.

The fourth generation of human rights has emerged with development. In addition, fourth-generation researchers define global rights and include such rights as the right to nuclear and environmental security (I.D. Afanasyeva), security from international terrorism (L.S. Agibalova), cyberspace security and space rights (M.Yu. Yatsishin).

Human rights are a sensitive barometer that responds to the emergence of new and changing public relations (Yu.D. Kokambo). The development of science, rapid technological progress are the main characteristics of modern society and cannot but affect the ethical and legal foundations of the life of the latter (I.V. Goncharov). Together with a change in social morality, they have led to the emergence of fourthgeneration human rights (0.0. Barabash).

Some researchers also talk about the emergence of the fifth and sixth generation (S.I. Iventiev, E.V. Ponomareva, G.Sh. Chernova).

In modern conditions, the question of the responsibility of robots arises. Questions of regulation of artificial intelligence, etc. There are challenges related to the environment, gender, sexual orientation, religion. New forms of discrimination are emerging.

In such circumstances, a balance must be struck between human rights and freedoms and the security of the state.

M.P. Orzikh stated that: "... the center around which all theoretical and applied human rights issues revolve" is the social connection "civil society - state - human" [5]. This 
dependency, it seems, is the perfect harmony for the development of the state and society. However, it would be advisable to add nature to this chain. It is possible to achieve similar by changing the vector in the understanding of each link of these issues. It is important to strike a balance in these relationships.

The development of society has already moved beyond the boundaries of the fourth generation. And it may be appropriate to talk about the latest generations of human rights, including those related to the information society and technological development.

In addition to the latest human rights, we must also talk about the development and transformation of fundamental human rights. In particular, over time, the right to life and health has acquired and is gaining new meaning and understanding.

\section{Right to life and right to development in the context of the Convention}

A person, his life and health, honor and dignity, integrity and safety are recognized in Ukraine as the highest social value in accordance with Part 1 of Art. 3 of the Constitution of Ukraine. This article is one of the foundations of the social and state order, which is enshrined in the Constitution, it is the normative and legal foundation of the humanistic orientation of the development of public and state life in Ukraine, it «sets the tone» for all subsequent constitutional prescriptions that reflect the real or desirable state of a person in Ukrainian society [6].

Respect for and protection of human rights is one of the guiding directions of the European Union's activities, in accordance with the objectives and principles of that organization, as enshrined in the founding treaties. The EU Charter of Fundamental Rights of 2007 provides a list of fundamental rights and freedoms that are recognized by each person within the European Union. In particular, personal rights and freedoms (Chapters I and II of the Charter) belong to 
natural rights and are inherent in any person from birth. They cover the right to human dignity, the right to life, the right to the integrity of the person, the right to liberty and security of person, the right to respect for private and family life, the right to protection of personal data, the right to marry and found a family, freedom of thought, conscience and religion, freedom of expression and information, freedom of assembly and of association, Freedom of the arts and sciences, Right to education, Freedom to choose an occupation and right to engage in work, freedom of movement and choice of location, right to asylum. The main duty of the Charter is to respect and protect human dignity. The Charter also contains provisions on abuse of law (Article 54). It is to prevent the authorities or individuals from eliminating or unduly restricting the rights and freedoms of others.

Human rights and fundamental freedoms (the right to life, liberty and security of person, respect for privacy and family life, prohibition of torture, slavery, etc.), which must be protected and protected worldwide, are enshrined in the Convention. They are fundamental, but under the influence of time their interpretation may change.

Many ECtHR decisions emphasize that the Convention is a living instrument and therefore the content of stable eternal values may change depending on the economic, social and cultural situation, which also confirms the axiomatic nature of human rights as a concept. The dynamics of the Convention («living instrument») are linked to human qualities and human interaction in society, since violations of rights (mainly crimes) are not possible without social interaction.

Each appeal to the ECtHR can dramatically change the approach to the interpretation of a particular right or freedom for the world and Ukraine in particular.

In the event of a violation of the rights enshrined in the Convention, and subject to the passage of all national courts, the person may apply to the ECtHR for the protection of his or her violated right. The specificity is that the complaint is filed not 
against a certain person, but against a state that did not ensure the realization of human rights and freedoms at the national level.

Based on Part 1 of Art. 2 of the Convention, no one shall be deprived of his life. Before the adoption of the Protocols number 6 and 13 of the Convention, deprivation of life shall not be regarded as inflicted in contravention of this Article when it results from the use of force which is no more than absolutely necessary: (a) in defence of any person from unlawful violence; (b) in order to effect a lawful arrest or to prevent the escape of a person lawfully detained; (c) in action lawfully taken for the purpose of quelling a riot or insurrection.

In view of the provisions of Art. 1, 2 of the Protocol No. 6 to the Convention on the Abolition of the Death Penalty of 28 April 1983 (as amended on 11 May 1994) ETS No. 114 the death penalty shall be abolished. No one shall be condemned to such penalty or executed (art. 1). A State may make provision in its law for the death penalty in respect of acts committed in time of war or of imminent threat of war; such penalty shall be applied only in the instances laid down in the law and in accordance with its provisions (art. 2).

Until the adoption of Protocol No. 6 of the Convention, the violation of the right to life was also not considered to be the execution of a sentence prescribed by a lawful sentence of a court: "no one shall be intentionally deprived of life other than the execution of a death sentence given by a court for which such a penalty is provided by law". However, following the adoption of Protocol No. 6, the use of such a sentence (death penalty) was declared inadmissible, except in martial law. Protocol No. 13 of the Convention on the Abolition of the Death Penalty in All Circumstances (Vilnius, 3 May 2002) states that Protocol No. 6 to the Convention concerning the abolition of the death penalty does not preclude the use of the death penalty for acts committed during war or the imminent threat of war. In other cases, the death penalty is abolished. No one shall be sentenced to death or executed without any warning.

The right to life as one of the highest humanistic human rights is protected and protected by the Criminal Code of 
Ukraine through the existence in it of punishment for intentional or negligent deprivation of the life of another person (Articles 115-118 of the Criminal Code).

However, this prohibition is a retreat consistent with the principles of law, in particular humanism.

A person shall not be held criminally liable for the deprivation of another person's life if he or she was killed in the process of necessary defense, if a person was assaulted by a group of persons, when they were assaulted at the person's home and using a weapon (Article 36 of the Criminal Code of Ukraine). Violation of the right to life, in the sense of the Convention, also implies an encroachment on the freedom to directly fulfill the natural needs necessary for human life and development. Each article of the Criminal Code of Ukraine provides for the protection of humanistic rights and freedoms provided for in the Convention or certain aspects of such rights.

Under the influence of a number of factors, the view and the level of tolerance for violations of the right to life have changed, as well as the understanding of the right to life, not only as enshrined in domestic law and international legal instruments, the possibility of certain human behavior aimed at ensuring the integrity of one's life and freedom to dispose of it (narrow understanding), but also as a human freedom to directly realize the opportunities that it has as a result of belonging to the species Homo Sapience, and to satisfy the necessary biological, social, spiritual, economic and other needs are inseparable from man, objectively driven by the attainment of human development (broad understanding) [7].

Accordingly, in the sense of the Convention, the violation of the right to life also implies an encroachment on the freedom to directly fulfill the natural needs necessary for human life and development. In particular, it is important for both the security and freedom of human.

In order to ensure the right to life in the broadest sense, the current Criminal Code of Ukraine provides for criminal liability for bringing a person to suicide (Article 120 of the Criminal Code), which is the result of ill-treatment, blackmail, systematic 
humiliation of his human dignity or systematic unlawful coercion to acts that they contradict her will, suicide inclination, and other acts that promote suicide. In accordance with paragraph 28 of the Plenum of the Supreme Court of Ukraine «On the case-law on crimes against the life and health of the person» No. 2 of February 7, 2003, cruel treatment should be understood as ruthless, gross acts that cause physical or mental harm to the victim (torture, systematic injury or beating, deprivation of food, water, clothing, housing, etc.). The systematic humiliation of human dignity is the long humiliating attitude towards the victim (constant insults, mockery of him, etc.).

In this context, the individual should be responsible for the freely chosen undesirable behavior, but in the manner prescribed by law.

However, it should be noted that, in the event of a state of emergency, there may be some deviations from the convention (derogation). Some countries in the world are moving away from certain provisions of the Convention. Due to the Coronavirus pandemic, in 2020 six states have already declared derogation [9]. In view of the restrictive measures taken to combat COVID-19, member states of the Council of Europe have begun to notify the Secretary-General of the CoE of a derogation from certain provisions of the European Convention on Human Rights, as provided for in Article 15 of the Convention. According to Part 1 of Art. 15 ECHR «In time of war or other public emergency threatening the life of the nation any High Contracting Party may take measures derogating from its obligations under this Convention to the extent strictly required by the exigencies of the situation, provided that such measures are not inconsistent with its other obligations under international law. No derogation from Article 2, except in respect of deaths resulting from lawful acts of war, or from Articles 3, 4 (paragraph 1) and 7 shall be made under this provision». As of today, applications for derogation through COVID-19 measures have been made by Latvia; Romania; Moldova; Armenia; Estonia; Georgia. 
Права людини в Україні та у зарубіжних країнах:

проблеми теорії та нормативно-правової регламентації

\section{Challenges regarding development of human rights}

\subsection{Human rights and biomedicine}

Human rights challenges are posed by scientific and technological developments as well as by the evolution of established practices in the biomedical field.

New technologies are emerging, for instance in the field of genetics, and some technologies, such as those involving artificial intelligence and big data, are being combined to produce new applications. The application of emerging and converging technologies in biomedicine results in a blurring of boundaries, between the physical and the biological sciences, between treatment and research, and between medical and non-medical purposes. Although they offer significant opportunities within and beyond the field of biomedicine, they also raise new ethical challenges related to inter alia identity, autonomy, privacy, and non-discrimination. The Committee on Bioethics has been discussing these emerging and converging technologies for some time and has developed considerable expertise in addressing the human rights challenges posed by them.

Important human rights challenges are also emerging through established practices in the field of biomedicine. Changes in the perception of the decision-making capacity in children, persons with mental health difficulties, and vulnerable older persons, are prompting reconsideration of the balance between protection and respect for autonomy. In addition, important demographic changes, such as migration and ageing populations, coupled with budgetary restrictions in healthcare, are resulting in new or increasing barriers to accessing healthcare services. At the same time, there is unprecedented scientific progress, which results in innovative therapies that are not always available or affordable to disadvantaged individuals and groups [19]. There are also some deviations from the concept of human rights in organ transplantation, cloning, and trafficking in human beings.

\subsection{Risks and dangers of human rights in postmodernity}

The dangers of postmodernity are that it lacks boundaries, templates and standards. The individual proceeds from his own 
experience, the experience of a close environment, not centuries-old norms of social morality and morality. The content of human rights and freedoms is spread and blurred or replaced by interests, comfort, benefits, etc. [12] without taking into account the responsibilities, and also encroaching on the freedom of others. Criminal law is also changing, largely driven by changes in the vector of anthropocentric tendencies (in particular, modern criminal law protects human life, honor and dignity, sexual freedom and integrity regardless of social status, demographic characteristics of the individual, etc.). Gradually blurring the boundaries of natural rights, begin to safeguard the virtual, the superhuman, and the intrinsic of humanity, such as the right to access personal data, which leads to the "twilight" of the original concept of human rights and does not contribute to the balance of freedom and security [10].

Eric Posner (USA) has published a book "Twilight of Human Rights". And he said that "human rights are ineffective or less effective when there are too many rights. When there are many rights, the state can justify its inability to respect one right, insisting that it has exhausted its financial and political resources while trying to secure other rights".

Postmodern ideas are further transformed in the conditions of post-truth, cyberspace, the interpenetration of sciences under the influence of socio-cultural, economic and other features of the information society. In post-truth circumstances, facts become less important in shaping public opinion than emotional subjective perception; the concept of rights, freedoms, duties, responsibilities and more are being blurred. Post-truth is the word of the year of the Oxford Dictionary for 2016, as this year is best characterized by a word that questions the concept of the facts themselves. Truth is defined as the circumstances in which objective facts lose their influence on society, they are replaced by appeals to emotional perception and personal faith.

Modernity is characterized by the great ability of individuals to freely transmit and receive information. The spread of the concept of post-truth is facilitated by the peculiarities of the 
information society, in particular the enhancement of the role of information and knowledge in society, the creation of a global information space, and people's access to world information resources, among which are false. Therefore, the information society is also characterized by manipulation of information.

It is now very dangerous that human rights do not contradict the idea of social naturalism (O.M. Kostenko). Often, modern human rights violate environmental security. In addition, the danger is to replace human rights with the needs of others. The Convention sets out fundamental human rights that cannot be violated with some exceptions.

\subsection{Transhumanism}

Companies today are strategizing about future investments and technologies such as artificial intelligence, the internet of things, or growth around new business models.

Visionary Innovation Group looked at three fundamental pillars of humanity and how they will evolve over the coming 10-15 years: bodies, thought, and behavior. After identifying the driving forces that will transform these fundamental pillars, we extracted key themes emerging from their convergence. Ultimately our goal was to determine the ways in which the changing nature of humanity and transhumanism would affect individuals, society, businesses, and government. A few of the trends that emerged from this study include the following trends.

Bodies will be augmented. The coming years will usher in a number of body augmentation capabilities that will enable humans to be smarter, stronger, and more capable than we are today. There are in particular exosuits that increase physical strength. We will also see increased use of implants ranging from brain microchips. But the most powerful body augmentation will come from biological augmentation as a result of increased insight into our genomes, advances in IVF technology that may allow us to select the most intelligent embryos [16]. These body augmentation capabilities will give rise to humans that are more resilient, optimized and 
continually monitored. They will also lead to implications around which job opportunities are available to those with and without augmented abilities. At the same time, augmented bodies will usher in risks such as espionage potential via contact lens camera hacks, or even more worryingly, risk of a stratified human race based on those who can afford augmentations and those who cannot.

Thought processes will be faster and more transferable. Both wearable and implantable brain-machine interfaces (BMIs) are in development from organizations that include Elon Musk's Neuralink, Facebook, and DARPA. These devices will dramatically alter the ways in which we communicate with each other, as well as digital devices [17].

Gamification and behavioral science will increase human productivity. Early innovators such as UBER are already harnessing the incredible combined power of behavioral science, gamification, and AI. Gamification techniques used by the company include a graphical interface that brings a videogame like quality to the drive, as well as prompting goals that are always just out of reach to encourage continued pursuit [22]. Even governments have taken up these tactics with behavioral science units in both the UK and US.

Human will be more empathetic. The adoption of virtual reality can play an influential role in our ability to understand perspectives other than our own [14]. BMIs may advance our ability to empathize if we are able to understand someone else's full perspective straight from their own brain, rather than if they are trying to communicate it and misspeak or their intention is misinterpreted by the listener.

The extreme personalization and customization. Marketers may be able to use emotional filters based on our activity to change the tone of their message on the spot in response to our current mood. Eventually, we may see AI personalization affect our career trajectory, playing a guiding role in the positions we are offered based on our personal strengths. Personalisation will eventually give way to customisation at mass scale where 
products and services will be completely configured to personal needs and preferences.

Changes in business practices. We will see the rise of AI in our career settings as described in much work focused on smart factories, industrial IOT, and related topics. Most employees will have an AI counterpart with which they collaborate or through which their work is amplified [23]. Integration of BMI into workplaces will usher in heightened cybersecurity concerns, and we may see eventual scenarios in which companies are sponsoring nootropic supplements and neurostimulation devices to improve employee focus and increase the speed of new skills acquisition [20]. However, such innovations can violate the health, privacy of the employee and risks of increasing unemployment.

\section{Threats and benefits of the human rights innovation}

All of the human rights innovation and new opportunities can be useful in the development of mankind. At the same time, all these innovations blur human identity and contradict some fundamental rights and freedoms.

In today's context, it is truly impossible for a person to analyze such a large amount of information, or not to be able to do so in the short term in which it is necessary. The use of Big Data (decision-making based on too much information) [4] and Internet of Things [2] technologies could help a person.

For example, processing declarations in the short term and taking into account many factors for analysis while simultaneously correlating this information with other sources would facilitate timely detection of corruption, corruption risks and accordingly contribute to counteracting and preventing corruption. That is, the Internet of Things would help the state fulfill its function of ensuring its own security and that of the society as a whole.

The state is now ready to provide the fundamental humanistic rights, freedom and security of its citizens, morality for the sake of security against certain crimes, in particular 
particularly grave crimes with a cross-border dimension. These include, for example, terrorism, trafficking in human beings, sexual exploitation of women and children, drug and arms trafficking, money laundering and counterfeiting, corruption, computer and organized crime.

To prevent crime, the state at the level of the law allows to derogate from the absolute prohibition of encroachment on property, health and even human life, as well as privacy. The state justifies such steps by the absence of other means to counteract crime. However, it should be remembered that such retreats are for the purpose of protecting human rights and freedoms, and not vice versa.

Although the latest Taricco II, Ecj 2017, Tsezar and others v. Ukraine, ECHR 2018, demonstrate the collective priority of the individual (European and national values) and the authority to punish their citizens [21].

However, other issues related to the security of the individual and his or her private information arise due to the processing and availability of big data, including «big private data».

Victimology scientists and scientists recommend that you do not post private information on social networks, or do it as little as possible (V.O. Tuliakov) for the sake of your own safety in order to prevent victimization.

Discrimination. Due to the emergence of new technologies and capabilities, there is a risk not only of development but also of the disappearance of the concept of human rights. In particular, not all people will have the financial capacity to improve their functions. Such transformations are contrary to human nature.

In addition, the latest technologies can be used to manipulate consciousness (N.A. Savinova). The right to be forgotten has recently been discussed in the context of ECtHR practices because innovative technologies make it impossible to forget anything. Information from the past person can be used at any time. And in fact, a person has no right to error and 
change. Any glimpses of the past will affect the reputation in the information society.

The right to education and privacy in quarantine. In quarantine, most Ukrainian educational institutions have implemented distance learning using the ZOOM service. However, such a service violates privacy. Recordings of conferences, participants' screenshots can be saved and used.

The price of human rights, freedom, and security in the face of globalization. In addition, the latest opportunities are a threat to human identity, human nature and privacy. In his futuristic novel Equilibrium, D. Orwell demonstrates a model of a world without wars, cruelty and no emotion. The ability to feel in any way emotionally responding to reality qualifies as an «emotional crime» and is put to death. To suppress emotions people use the drug «Prozium». For his non-use, the person also undergoes a «procedure». It is believed that emotions are the cause of serious crimes, wars and more. In this novel, the rejection of emotions is the price of security. In essence, it is a rejection of the human essence, because a person is inherent in sensuality. The meaning of human existence is to freely choose the right behavior, thus exercising its freedom.

Equally frightening is the total observation and control of the man in Orwell's 1984 novel. This novel describes a totalitarian regime with its rewriting of history, zombification of people by the party's patriotic slogans. There are no laws and punishments in such a world. The party detains people for thoughts - «thought-crimes». In such a state there are Ministries of Truth (which deals with lies), Love (deals with torture), Thoughts (similar to police), Peace (deals with war). People should feel nothing but love for the party and hatred for enemies.

Unfortunately, these novels are not fantastic. Although hyperbolized, they show real events in the history of Ukraine and the world.

For example, in modern China, there is a system of disclosure of private information in public access, according to which the "rating of the person" is formed and taken into 
account when hiring, which is a form of control of private information. In response to the Coronavirus counteraction, a real-name registration requirement for public transport trips has been introduced in China since February 24, 2020, which also facilitates citizen travel control.

In Ukraine (though not officially), individual posts are verified, including through social networks and the media (for example, working in the Anti-Corruption Court). Regular users of the Internet are already actively using programs to identify a person's location using a mobile phone, applications that allow you to view contacts in another's mobile phone, etc. All this violates the privacy and rejection of the needs of others. But how much we are ready to give in to our freedom and privacy in the future for the sake of the security of the state and to simplify the performance of its functions through total control. In the future, as already noted, there will also be an opportunity to access emotional reactions and thoughts of a person as if to improve service and understanding of a person by a person. However, it is an incredible threat to privacy and security.

A person feels safe, including when he or she is in control of his or her own life, when he or she is less aware of what is going on in his / her life, when he / she is financially able to provide himself / herself with food, shelter, development opportunities, etc. Criminal liability now consists of mutual rights and obligations between the state (law and justice), the offender (punishment), victims (fair treatment), and third parties (cognitive control). Mutual rights mean that criminal rules need to be built towards effectively changing the treatment of a person, taking into account the needs of all parties involved [21]. This is possible through mediation and dialogue practices.

Pope Francis II spoke to the lawyers on November 15, 2019 at the 20th Congress of the International Criminal Law Association in the Vatican [18], stating that global financial capital is the source of serious crimes not only against property but also against people and the environment. It is organized crime that is responsible, among other things, for the over-indebtedness of states and the plundering of the natural resources of our planet. Criminal law 
must not remain unconnected with conduct in which, by taking advantage of asymmetrical situations, a dominant position is exploited to the detriment of collective welfare. This is the case, for example, when the prices of public debt securities are artificially reduced through speculation, without worrying that this will affect or aggravate the economic situation of entire nations. These are crimes that have the seriousness of crimes against humanity, when they lead to hunger, misery, forced migration and death from avoidable diseases, environmental disaster and ethnocide of indigenous peoples. Need protection of the environment by criminal law. «Ecocide» it is the massive contamination of air, land and water resources, the large-scale destruction of flora and fauna, and any action capable of producing an ecological disaster or destroying an ecosystem. We must introduce - we are thinking about it - in the Catechism of the Catholic Church the sin against ecology, the ecological sin against the common home, because it is a duty. It is a sin against future generations and is manifested in acts and habits of pollution and destruction of the harmony of the environment, in transgressions against the principles of interdependence and in the breaking of networks of solidarity between creatures (cf. Catechism of the Catholic Church, 340-344). As has been pointed out in your work, «ecocide» is to be understood as the loss, damage or destruction of the ecosystems of a given territory, so that its utilization by inhabitants has been or can be seen as severely compromised. This is a fifth category of crimes against peace, which should be recognised as such by the international community [18].

That is, a balance must be struck between the freedom and security of the state, as well as the security of the environment. After all, securing fundamental rights (life and health) is impossible without a safe environment.

\section{Conclusions}

The Convention on Human Rights enshrines fundamental human rights that cannot be violated in a rule of law and democracy. However, there are also some exceptions to these 
rights. Such exceptions can be attributed to the state of emergency, war, etc.

The development of society has already moved beyond the boundaries of the fourth generation. And it may be appropriate to talk about the latest generations of human rights, including those related to the information society and technological development.

In addition to the latest human rights, need to talk about the development and transformation of fundamental human rights. In particular, over time, the right to life and health has acquired and is gaining new meaning and understanding.

The information society has given a new impetus to the development of human rights. At the same time, opportunities to increase and improve the body, use of microchips to increase memory, the ability of marketers to customize the service not only personal preferences, but also through emotional perception. Such opportunities develop, but are also a threat to, human rights. Such opportunities are a threat to the identity of human, an understanding of his natural essence and the continued existence of the genus.

In today's context, it is important that human rights do not contradict the idea of social naturalism (O.M. Kostenko). Often, modern human rights violate environmental security.

In addition, it is important that human rights are not replaced by the needs of others. The Convention sets out fundamental human rights that cannot be violated with some exceptions.

In ensuring human rights, it is important to strike a balance between human, society, the state and the environment.

\section{References:}

1. Барабаш 0.0. Четверте покоління прав людини: загальнотеоретична характеристика. Вісник Національного університете «Львівська політехніка». Юридичні науки. 2016. № 837. С. 213-217.

2. Баранов О.А. «Інтернет речей» як правовий термін. Юридична України. 2016. № 5-6. С. 96-103. 
3. Булеца С.Б., Заборовський В.В., Стойка А.В. Деякі проблемні питання правового захисту прав людини четвертого покоління. Науковий вісник Ужгородського національного університету. Серія ПРАВО. Випуск 55. Том 1, 2019. С. 10-14.

4. Карчевський B.M. Можливості Big Data та кримінально-правова комунікація. Політика в сфері боротьби зі злочинністю: Міжнародна науково-практична конференція (м. Івано-Франківськ, 9-10 грудня 2016 р.). С. 52-58.

5. Орзих М.Ф. Конституционное положение человека в государстве и обществе Украины. Юридический вестник: научно-публицистический журнал. 1997. № 2. С. 60-62.

6. Рабинович П.Л. Философия прав человека в Конституции Украины. Юридический вестник. 1997. № 2. C. 57-59.

7. Рогова О.Г. Право на життя в системі прав людини : автореф. дис... канд. юрид. наук: 12.00.01; Нац. юрид. акад. України ім. Я. Мудрого. Харків, 2006. 20 с.

8. Соловйов А. Право людини на життя: міжнародний вплив на формування українських поглядів. Конституційне право. 2007. № 12. С. 8-14.

9. Страны-члены Совета Европы сообщают об отступлении от некоторых положений ЕКПЧ из-за пандемии. URL: https://zn.ua/WORLD/strany-chleny-sovetaevropy-soobschayut-ob-otstuplenii-ot-nekotoryh-polozheniyekpch-iz-za-pandemii-349192_.

10. Тімофєєва Л.Ю. Гуманістична парадигма: досвід, виклики та перспективи кримінального права України: монографія. Харків : Право, 2020. 280 с.

11. Туляков В.А. Гибридность права в современном уголовно-правовом дискурсе. Правові та інституційні механізми забезпечення розвитку держави та права в умовах євроінтеграції : матеріали Міжнар. наук.-практ. конф. (20 травня 2016 р., м. Одеса). Одеса : Юридліт, 2016. C. 167-169. 
12. Юдківська Г. Сутінки прав людини і Європейський суд. URL: http://ua.racurs.ua/1136-prava-ganna-udkivska.

13. Яцишин М.Ю. Сучасні тенденції у сфері міжнародноправового регулювання кіберпростору. Проблеми ефективності міжнародного права : матеріали міжнар. наук.-практ. конф., м. Київ, 29 березня 2013 р. / за заг. ред. В.Н. Кубальського. Київ : Інститут держави і права ім. В.М. Корецького НАН України, 2013. С. 103-106.

14. What if virtual reality can make us better citizens? City Lab. October 2016. URL: https://www.citylab.com/life/2016/ 10/virtual-reality-empathy-natural-world/502694/.

15. Vasak K. A 30-year struggle; the sustained efforts to give force of law to the Universal Declaration of Human Rights. The UNESCO Courier: a window open on the world. 1977. URL: https://unesdoc.unesco.org/ark:/48223/pf0000048063/PDF/ 074816engo.pdf.multi.nameddest $=48063$.

16. How Humans Are Shaping Our Own Evolution. National Geographic. April 2017. URL: http://www.nationalgeographic.com/ magazine/2017/04/evolution-genetics-medicine-braintechnology-cyborg/.

17. The entrepreneur with the $\$ 100$ million plan to link brains to computers. MIT Technology Review. March 2017. URL: https://www.technologyreview.com/s/603771/theentrepreneur-with-the-100-million-plan-to-link-brains-tocomputers/.

18. Pope, Francis. Address of his holiness Pope Francis to participants at the World Congress of the International Assotiation of Penal Law. Sala Regia, 15 November, 2019. URL: http://www.siracusainstitute.org/app/wpcontent/uploads/2019/11/ADDRESS-OF-HIS-HOLINESS-POPEFRANCIS.pdf.

19. Strategic Action Plan on Human Rights and Technologies in Biomedicine (2020-2025). 1367th meeting, 12 February 2020. Committee on Bioethics (DH-BIO) CM(2019)198 18/12/2019. URL: https://search.coe.int/cm/ Pages/result_details.aspx?ObjectId=0900001680994df7. 
20. Sarwant Singh. Transhumanism And The Future of Humanity: 7 Ways The World Will Change By 2030. URL: https://www.forbes.com/sites/sarwantsingh/2017/11/20/tra nshumanism-and-the-future-of-humanity-seven-ways-theworld-will-change-by-2030/\#7e1f5b877d79.

21. Tuliakov V. «Eurocrimpol» project: methodology of analysis. Кримінальне право в умовах глобалізації : матеріали Міжнародної науково-практичної конференції, м. Одеса, 25 травня 2018 року. Одеса : НУ «Одеська юридична академія», кафедра кримінального права, 2018. C. 64-66.

22. How Uber uses psychological tricks to push its drivers' buttons. The New York Times. April 2017. URL: https://www.nytimes.com/interactive/2017/04/02/technology/ uber-drivers-psychological-tricks.html.

23. The 10 skills you need to thrive in the fourth industrial revolution. The World Economic Forum. January 2016. URL: https://www.weforum.org/agenda/2016/01/the-10-skillsyou-need-to-thrive-in-the-fourth-industrial-revolution/. 
DOI https://doi.org/10.36059/978-966-397-210-7/369-391

\section{Шевченко А. $\epsilon$.,}

доктор юридичних наук, професор, заслужений юрист України, завідувач кафедри теорії, історії права і держави та конституційного права Університету державної фіскальної служби України, м. Ірпінь, Київська область

Кудін C. B., кандидат юридичних наук, доцент, доцент кафедри теорії, історії права і держави та конституційного права

Університету державної фіскальної служби України, м. Ірпінь, Київська область

\section{КОНСТИТУЦІЙНІ ЗАСАДИ ЗАБЕЗПЕЧЕННЯ ПРАВА ЛЮДИНИ НА ЗДОРОВ'Я: ПОРІВНЯЛЬНО-ПРАВОВЕ ДОСЛІДЖЕННЯ}

Анотація. Метою дослідження $\epsilon$ виявлення на основі компаративно-правового аналізу спільних $i$ відмінних рис конституційного забезпечення права людини на здоров'я в Україні і Чеській Республіці й Польській Республіці. Основним завданням виступає узагальнення досвіду Чехії і Польщі, а з його врахуванням - й визначення напрямів удосконалення конституційного законодавства Украӥни в цій сфері. Встановлено, що конституційне забезпечення права на здоров'я людини в Україні міститься не лише в Основному законі, але й низці конституційно-правових актів, а проведений аналіз відповідних норм засвідчує недостатню досконалість дефініцій понять і термінів, які мають віддзеркалювати зазначене право. Виявлено, що проблемами у сфері охорони здоров'я в Україні є: відсутність сталої Концепції побудови нової національної 
системи охорони здоров'я, повільність проведення медичної реформи, започаткованої у 2017 р., і відходу від радянської централізованої системи управління охороною здоров'я населення. З'ясовано, що конституції зазначених держав мають спільні риси щодо формулювання конституційних засад забезпечення права людини на здоров'я. Разом із тим виявлено, що досвід організації системи охорони здоров'я у Польській Республіці і Чеській Республіці потребує внесення змін до конституційно-правових актів Украӥни. Виявлено, що такі зміни мають бути спрямовані на: більш чітке формулювання дефініцій основних понять і термінів, які визначають право на здоров'я людини, формування децентралізованої системи охорони здоров'я, яка б відповідала основним засадам політики ЄС у сфері охорони здоров'я. З'ясовано, що досвід боротьби з поширенням інфекційної хвороби коронавірусу у країнах ЄС може бути адаптований органами державної влади Украйни.

\section{Вступ}

Істотне погіршення стану навколишнього природного середовища в Україні в останній чверті XX - на початку XXI ст., пов'язане із цілим комплексом проблем: рядом аварій техногенного характеру, забрудненням атмосферного повітря через викидання промислових відходів й збільшення використання автотранспортних засобів, погіршенням екологічного стану водних ресурсів тощо, у сукупності - 3 погіршенням якості уживаних продуктів харчування, веденням нездорового способу життя, незадовільною ситуацією у сфері медичного забезпечення охорони здоров'я - спричинило зростання кількості хворих громадян, зменшення тривалості життя серед українців (станом на травень 2018 р. вона $\epsilon$ найнижчою в Європі; середній вік жінок становить 77 років, чоловіків - 67) [1]. У проекті Концепції побудови нової національної системи охорони здоров'я України зазначається, що Україна має один із найгірших показників серед систем охорони здоров'я в європейському регіоні, i знаходиться на другому місці за рівнем смертності 
(14,9 на 1000 населення), яка збільшилась на 12,7\% за останні 20 років, тоді як у Європейському Союзі цей показник знизився на 6,7\% [2]. До того ж, ситуація істотно погіршилась у зв'язку із стрімким поширенням на початку 2020 р. у світі та Україні коронавірусної інфекції COVID-19 (так, в Україні на 24 квітня було офіційно зареєстровано 7647 випадків інфікування, від хвороби померло 193 осіб, а повністю одужало - 601) [3].

Отже, слід констатувати погіршення демографічної ситуації в Україні. Наразі йдеться не тільки про іï покращення, але й збереження генофонду нації, що впливає й національну безпеку України, адже «створення дієвого механізму захисту прав людини $\epsilon$ запорукою мінімізації загроз для національної безпеки України, що особливо актуально в умовах викликів сьогодення» $[4$, c. 346].

Зазначене вище актуалізує вирішення проблеми забезпечення права людини на здоров'я, в першу чергу - на конституційному рівні, а також створення дієвого механізму реалізації цього права. Так, у розділі II Основного закону України були закріплені природні, політичні, соціальні, економічні, культурні, сімейні, екологічні, інформаційні та інші права й свободи людини і громадянина в Україні [5, с. 536].

Разом із тим прагнення України вступити до $€ C$, свідченням чого $€$ підписання Угоди про асоціацію між Україною та Європейським Союзом від 21 березня та 27 червня 2014 р., накладає свій відбиток і не необхідність звернення уваги до досвіду закріплення конституційних засад забезпечення права людини на здоров’я у країнах, які належать до Європейського Союзу.

У даному контексті слід, на нашу думку, здійснити компаративний аналіз конституційних засад забезпечення права людини на здоров'я в Україні й таких державах, як Чеська Республіка та Польська Республіка. Підставою вибору конституцій даних країн $\epsilon$ те, що вони, по-перше, як і УРСР, певний час перебували у радянській політико- 
правовій системі, по-друге, $\epsilon$ одними 3 послідовних прихильників вступу України до $€ C$, по-третє, нас об’єднують давні історичні стосунки дружби й співробітництва, а у правовій сфері - взаємної рецепції норм законодавства, їх адаптації до місцевих умов.

\section{1. Конституційні засади забезпечення права людини на здоров'я в Україні}

У статті 3 Конституції України 1996 р. зафіксовано, що «Людина, іï життя i здоров'я, честь і гідність, недоторканність і безпека визнаються в Україні найвищою соціальною цінністю. Права і свободи людини та їх гарантії визначають зміст і спрямованість діяльності держави. Держава відповідає перед людиною за свою діяльність. Утвердження i забезпечення прав і свобод людини $\epsilon$ головним обов'язком держави» [6]. Із даного засадничого принципу закономірно випливає й логіка побудови за пріоритетами функцій держави, стратегічних і тактичних цілей її діяльності розділів Основного закону України. Саме тому права, свободи та обов'язки людини і громадянина закріплено в розділі II. Конституційне ж закріплення на сьогодні прав і свобод людини як найвищої цінності та їхня відповідність міжнародним нормам права $\epsilon$ одною 3 важливих ознак демократичної держави, тому невід'ємним та непорушним правом кожної людини є право на охорону здоров'я [7, с. 25].

Оскільки право на здоров'я належить до групи невід'ємних прав, то природно, що законодавець приділив увагу його конституційному забезпеченню вже у перших статтях розділу II. Так, у частині 3 статті 27 зазначається, що «кожен має право захищати своє життя і здоров'я, життя і здоров'я інших людей від протиправних посягань». Стаття 28, хоч прямо і не визначає право на здоров'я, тим не менше, 3 юридичного аналізу їі тексту випливає прагнення держави забезпечити це право: «Ніхто не може бути підданий катуванню, жорстокому, нелюдському або 
такому, що принижує його гідність, поводженню чи покаранню. Жодна людина без її вільної згоди не може бути піддана медичним, науковим чи іншим дослідам» (частини 2 і 3) [6].

Із правом на здоров'я тісно пов'язані й інші права. Зокрема, у частинах 1-3 статті 49 йдеться про те, що «Кожен має право на охорону здоров'я, медичну допомогу та медичне страхування. Охорона здоров'я забезпечується державним фінансуванням відповідних соціальноекономічних, медико-санітарних і оздоровчо-профілактичних програм. Держава створює умови для ефективного і доступного для всіх громадян медичного обслуговування. У державних і комунальних закладах охорони здоров'я медична допомога надається безоплатно; наявна мережа таких закладів не може бути скорочена. Держава сприяє розвиткові лікувальних закладів усіх форм власності» [6].

Із правом на здоров'я пов'язане і закріплене у статті 50 право кожного на безпечне для життя і здоров'я довкілля та на відшкодування завданої порушенням цього права шкоди. Крім того, частина 2 цієї статті визначає, що «Кожному гарантується право вільного доступу до інформації про стан довкілля, про якість харчових продуктів i предметів побуту, а також право на ії поширення. Така інформація ніким не може бути засекречена» [6].

Право людини на здоров'я закріплене i в інших нормативно-правових актах, які за своїм характером $\epsilon$ конституційними, оскільки деталізують відповідні статті Конституції. Такими, зокрема, є: Закон України «Основи законодавства України про охорону здоров'я» (у редакції від 29.12.2019 р.) (в якому йдеться про: визнання пріоритетності норм міжнародно-правових актів (ст. 2); визначення дефініцій понять і термінів, що вживаються в законодавстві про охорону здоров'я (здоров'я, медична допомога, медичне обслуговування, медична послуга, охорона здоров'я тощо) (ст.3); формулювання основних принципів охорони здоров'я (ст. 4); інші базові принципові 
Права людини в Україні та у зарубіжних країнах:

проблеми теорії та нормативно-правової регламентації

положення) [8], Закон України «Про забезпечення санітарного та епідеміологічного благополуччя населення» (у редакції від 04.10.2018р.) (наголосимо на: визначенні основних термінів і понять, які містяться у ст. 1, зокрема, середовище життєдіяльності людини, шкідливий вплив на здоров'я людини, санітарно-епідемічна ситуація, вимоги безпеки для здоров'я і життя людини, сприятливі умови життєдіяльності людини тощо; закріплення права громадян на безпечні для здоров'я і життя харчові продукти, питну воду, умови праці, навчання, виховання, побуту, відпочинку та навколишнє природне середовище, участь у розробці, обговоренні та громадській експертизі проектів програм і планів забезпечення санітарного та епідемічного благополуччя населення, внесення пропозицій із цих питань до відповідних органів, відшкодування шкоди, завданої їх здоров'ю внаслідок порушення підприємствами, установами, організаціями, громадянами санітарного законодавства та інші) [9].

На перший погляд, конституційне забезпечення права людини на здоров'я в Україні $є$ достатньо грунтовним. Так, у вітчизняній юридичній науковій літературі визначаються, виходячи з тексту відповідних законів, такі права громадян у сфері охорони здоров'я, як право на профілактичні заходи, право на доступність, право на інформацію, право на згоду, право на свободу вибору, право на приватність і конфіденційність, право на безпеку, право на індивідуальний підхід до лікування, право на подання скарги, право на відшкодування шкоди тощо [10].

Проте ряд українських учених, юристів-практиків небезпідставно звертають увагу на істотні прогалини у чіткості визначення деяких понять і термінів, що містяться у вітчизняному законодавстві (включно з Конституцією України), і які мають розкривати сутність конституційних засад забезпечення права на здоров'я людини, а також на необхідність оновлення чинного конституційного законодавства в умовах проведення в Україні медичної реформи, започаткованої у 2017 р. А це, у свою чергу, 
впливає як на аутентичне тлумачення органами державної влади, місцевого самоврядування, судовими установами відповідних нормативних приписів, так і на безперешкодну реалізацію громадянами України своїх законних прав.

Такими прогалинами учені називають:

- відсутнє чітке розмежування змістів права на охорону здоров'я та на медичну допомогу;

- недостатню визначеність різниці в поняттях «медична допомога» i «медична послуга», а також відсутність врегулювання питань надання безоплатної чи платної медичної допомоги таким групам суб'єктів, як іноземці;

- нечіткість дефініції «державне управління охороною здоров'я» та «громадське здоров'я», а також відсутність у чинній конституційно-правовій базі деяких важливих понять (наприклад, «єдиний медичний простір»);

- недосконалість і невідповідність новим реаліям життя конституційно-правового закріплення гарантій реалізації права людини на здоров'я; повільність удосконалення нормативно-правового закріплення етапів проведення медичної реформи в Україні;

- недосконалість дефініцій «активна еуатаназія» i «пасивна добровільна еутаназія»;

- «конституційне право на охорону здоров'я та медичну допомогу в Україні (ст. 49 Конституції України) не повною мірою відповідає основним міжнародно-правовим стандартам, оскільки в міжнародних договорах, учасником яких $€$ українська держава, дане право розглядається набагато ширше, і включає в себе соціальне благополуччя людини» $[11$, с. $91 ; 12 ; 13$, с. $136 ; 14$, с. $112 ; 15$, с. $412 ; 16$; 17 , с. $228-229 ; 18$, с. 530 ].

У вітчизняній науковій літературі подаються і шляхи вирішення названих проблем, в основному, це стосується спроб надати авторські дефініції таким поняттям, як «право на охорону здоров'я», «право на медичну допомогу», «медична послуга», «єдиний медичний простір» тощо, пропонується удосконалити конституційно-правове 
закріплення гарантій реалізації права людини на здоров’я та інше. Достатньо позитивним $\epsilon$ той факт, що учені обгрунтовують свою позицію необхідністю звернення уваги до міжнародного й європейського досвіду конституційного закріплення права людини на здоров'я.

Закономірно, що на необхідності враховувати досвід країн Європейського Союзу грунтуються і основні положення різних проектів органів державної влади і управління, незалежних громадських організацій та нормативноправових документів, що мають визначати фундаментальні принципи побудови охорони здоров'я людини в Україні (це, зокрема, Проект Концепції побудови нової національної системи охорони здоров'я України, представлений М03 України 07.08.2014 року, Національна стратегія побудови нової системи охорони здоров'я в Україні на період 2015-2025 років, розроблена Стратегічною дорадчою групою з питань реформування системи охорони здоров'я в Україні (СДГ з охорони здоров'я), яка була створена Наказом МО3 № 522 від 24.07.2014 року, Постанова Верховної Ради України «Про Рекомендації парламентських слухань на тему: «Про реформу охорони здоров'я в Україні» від 21.04.2016 року, Концепція побудови нової національної системи охорони здоров'я України, анонсована Незалежною експертною платформою «ПРО S VITA» 08.11.2017 року та інші [2; 19; 20; 21]).

У зв'язку із проголошенням В03 пандемії у світі (COVID19) Українська держава активізувала свою діяльність, спрямовану на захист здоров'я своїх громадян. Базовими нормативними документами стали Закон України «Про внесення змін до деяких законодавчих актів України, спрямованих на запобігання виникненню і поширенню коронавірусної хвороби (COVID-19)» № 533-IX від 17.03.2020 р. [22], постанова Кабінету Міністрів України «Про запобігання поширенню на території України коронавірусу COVID-19» № 211 від 11.03 .2020 р. [23] та деякі інші (наразі таких документів 22). 
Основними заходами забезпечення права громадян на здоров'я є: встановлення карантину (з 12.03. до 03.04. 2020 р.), із забороною відвідування закладів освіти ії здобувачами, проведення всіх масових заходів, у яких бере участь понад 200 осіб, крім заходів, необхідних для забезпечення роботи органів державної влади та органів місцевого самоврядування. Спортивні заходи дозволяється проводити без участі глядачів (уболівальників). 2 квітня 2020 р. постановою КМУ карантин було продовжено до 24 квітня, а його умови стали більш жорсткими (наприклад, з 6 квітня 2020 р. заборонено перебування в громадських місцях без вдягнутих засобів індивідуального захисту, переміщення групою осіб у кількості більше ніж дві особи, крім випадків службової необхідності та супроводження осіб, які не досягли 14 років, батьками, усиновлювачами, опікунами, піклувальниками, прийомними батьками, батьками-вихователями, іншими особами відповідно до закону або повнолітніми родичами дитини, відвідування парків, скверів, зон відпочинку, лісопаркових та прибережних зон, крім вигулу домашніх тварин однією особою та в разі службової необхідності, відвідування спортивних та дитячих майданчиків тощо).

Згаданим же Законом України було внесено зміни i доповнення до Кодексу України про адміністративні правопорушення, Кримінального кодексу України, якими встановлено більш суворі санкції за порушення умов карантину, а внесені зміни до Кодексу законів про працю України, Податкового кодексу України, деяких інших нормативно-правових актів стосувались із формальної точки зору надання окремим категоріям громадян на час карантину пільг. Крім того, на період до 24.04 на всій території України було запроваджено надзвичайну ситуацію (посилення охорони громадського порядку, інформування громадян, дезінфекція об’єктів та територій, санітарно-гігієнічні протиепідемічні заходи тощо).

Не дивлячись на загрозливу ситуацію в Україні (стрімке поширення хвороби, відсутність необхідних засобів і ліків), 
тим не менше, українські громадяни (волонтери, меценати, представники бізнесу та інші) знайшли можливість надати допомогу медичним закладам і лікарям України. Крім того, наші лікарі знайшли можливість надати допомогу колегам у країнах ЄC (зокрема, українські медики протягом трьох тижнів надавали посильну допомогу у боротьбі із поширенням інфекційної хвороби (COVID-19) в Італійській Республіці), при цьому вони долучились до протоколів надання медичної допомоги, що дозволить у майбутньому цей європейський досвід використовувати у нашій країні під час боротьби із пандемією.

\section{2. Конституційні засади забезпечення права людини}

\section{на здоров'я в Польській Республіці і Чеській Республіці}

У зв'язку із зазначеним вище доречно звернути увагу на ті положення, які закріплюють право на здоров’я у конституціях двох названих держав. Як і в Конституції України, в Конституції Польської Республіки від 2 квітня 1997 р. стверджується принцип турботи держави за непорушність прав і свобод громадян. Це випливає, зокрема, зі ст. 5: «Польська Республіка стоїть на сторожі незалежності і недоторканості своєї території, забезпечує свободи і права людини і громадянина, безпеку громадян, стоїть на сторожі національної спадщини, а також забезпечує охорону довкілля, керуючись принципом збалансованого розвитку» [24]. Із цього закономірно випливає, що в Конституції Польської Республіки, як і в Конституції України, свободи, права і обов'язки людини і громадянина уміщені у розділі II.

Цікаво, що, як і у Конституції України, право на здоров'я прямо не визначається, але $з$ юридичного аналізу тексту Конституції Польської Республіки випливає намагання держави забезпечити це право. Так, у ст. 39 зазначається, що «Ніхто не може бути підданий науковим дослідам, включаючи медичні, без вільно вираженої згоди», а у ст. 40 - що «Ніхто не може бути підданий катуванню або жорстокому, нелюдському чи принизливому поводженню і 
покаранню. Забороняється застосування тілесних покарань» [24].

Разом із тим особливістю Конституції Польської Республіки $є$ те, що в ній проглядається позиція держави щодо закріплення типологізації прав і свобод людини i громадянина. Так, право на здоров'я віднесено до підрозділу «Особисті свободи і права», натомість право на охорону здоров'я уміщено до підрозділу «Економічні, соціальні і культурні свободи і права». Причому в Конституції Польської Республіки норма про право на охорону здоров'я, на нашу думку, виписана більш чітко, особливо, по-перше, у частині обов'язків держави дбати про забезпечення цього права; по-друге, зобов'язання держави опікуватись здоров'ям малозахищених із тих чи інших причин верств населення. Так, у ст. 68 зазначається, що «1. Кожний має право на охорону здоров'я. 2. Громадянам незалежно від їх матеріального стану публічна влада забезпечує рівний доступ до медичної допомоги, що фінансується за рахунок публічних коштів. Умови і обсяг надання медичної допомоги визначаються законом. 3. Публічна влада зобов'язана особливо піклуватися про здоров'я дітей, вагітних жінок, осіб 3 фізичними і розумовими вадами та осіб похилого віку. 4. Публічна влада зобов'язана боротися 3 епідемічними захворюваннями i попереджати негативні для здоров'я наслідки погіршення стану довкілля. 5. Публічна влада підтримує розвиток фізичної культури, особливо серед дітей і молоді» [24].

Так само чіткіше прописані обов'язки держави стосовно забезпечення охорони навколишнього природного середовища. Зокрема, у ст. 74 зазначається, що «1. Публічна влада здійснює політику, що забезпечує нинішньому i майбутнім поколінням екологічну безпеку. 2. Охорона довкілля $\epsilon$ обов'язком публічної влади. 3. Кожний має право на інформацію про стан довкілля і про його охорону. 4. Публічна влада підтримує дії громадян, спрямовані на охорону довкілля і покращення його стану» [24]. 
Крах у кінці 80-х років XX ст. «соціалістичного табору», прийняття Конституції Польської Республіки і Конституції Чеської Республіки започаткували й ряд істотних змін у сфері охорони здоров'я громадян цих держав. У першу чергу, це пов'язано 3 низкою проведених реформ у медичній галузі, а такий досвід $є$ корисним і для України, в якій відхід від «моделі Семашка» (фінансування лише за рахунок оподаткування, жорстка централізація, повне безкоштовне медичне обслуговування), на відміну від наших сусідів, відбувається лише з 2017 р.

Реформу у сфері охорони здоров'я людини і громадянина у Польській Республіці було проведено протягом 1997-2003 р. Так, у 1997 р. було прийнято Закон про загальне медичне страхування, а разом із тим створено Систему соціального медичного страхування, а також 17 фондів медичного страхування; у 2003 р. ці фонди були замінені Народним фондом охорони здоров'я, який фінансується за рахунок державного бюджету (система Беверіджа). «У даний час майже 98\% населення охоплено Системою соціального медичного страхування (SHI), яке $\epsilon$ обов'язковою для більшості громадян» [25, с. 14].

Як зазначають фахівці, «Польща побудувала фінансування медицини за принципом солідарного обов'язкового медичного страхування. Платником за медичні послуги i ліки виступає Національний фонд охорони здоров’я, наповнення якого відбувається через індивідуальні податкові відрахування. Їх здійснюють, у першу чергу, працівники і підприємці. Але навіть особи, які отримують допомогу 3 безробіття, зобов'язані робити такі відрахування» [26]. Ясно, що відрахування зазначених суб'єктів за своєю грошовою масою $є$ різними, проте, відповідно до Конституції Польської Республіки, доступ до медичних послуг, які надаються державними медичними закладами, $\epsilon$ рівний для усіх (у Польській Республіці всі лікарняні установи поділені на три типи: державні (як правило, великі і середні), приватні, і ті, які належать органам місцевого самоврядування). 
Важливою проблемою, вирішення якої $є$ актуальним i для України, є дилема: подальша централізація (радянська модель) чи децентралізація усієї системи охорони здоров'я. У Польській Республіці державне управління системи охорони здоров'я відповідає загальноприйнятим нормам Європейського Союзу про бажану децентралізацію такого управління. Тому-то «управління системою охорони здоров'я розділене між Міністерством охорони здоров'я, Народним фондом здоров'я та органами місцевого самоврядування. Міністерство охорони здоров'я встановлює національну політику і надає фінансування довгострокових цілей у сфері охорони здоров'я. Народний Фонд Здоров'я має справу з розподілом фінансування між застрахованим населенням. Місцеві органи влади несуть відповідальність за надання місцевих послуг в сфері охорони здоров'я, лікарні та оплату послуг та організацію лікарів» [25, с. 19].

Ясно, що будь-яка реформа проводиться не задля самої реформи, а покращення життя громадян. Досвід Польської Республіки (попри наявні, зрозуміло, проблеми) щодо реформ у сфері охорони здоров'я $\epsilon$ достатньо показовий: наприклад, у 2009 р. загальна тривалість життя жінок становила $80 \%$, а чоловіків - 71,6\% (в Україні ж відповідно, 77 і 67\%).

Поширення інфекційної хвороби коронавірусу торкнулось і Польської Республіки, причому перші випадки на захворювання у цій державі і в Україні були зафіксовані на початку березня. На 24 квітня у Польській Республіці кількість інфікованих складає близько 11 тисяч осіб. Слід відзначити, що влада в нашого сусіда відреагувала достатньо миттєво, адже кожний день бездіяльності міг призвести до непередбачуваної ситуації. Так, 6.03. президент А. Дуда підписав спеціальний закон про боротьбу із розповсюдженням коронавірусу. Його текст містить нормативні приписи, які у принципових положеннях $є$ подібними до тих приписів українського законодавства: хворі на коронавірус, а також особи з підозрою на наявність COVID-19 можуть 
підлягати додатковій госпіталізації. У законі також говориться про те, що з метою протидії розповсюдженню коронавірусу працедавець може доручити працівникові виконання роботи здому [27]. Крім того, в Польській Республіці було введено карантин, а з 1.04. режим істотно було посилено, 3 09.04. введено «масковий режим» (орієнтовно, карантин буде продовжено як мінімум до 26.04.). Крім того, з 20.03. встановлено більш високі штрафи за порушення умов карантину (у 6 разів) [28], введено «режим епідемії» (за обмежувальними заходами у цілому відповідає «надзвичайній ситуації» в Україні). Отже, на нашу думку, можна побачити схожі процеси нормативного закріплення заходів, що мають сприяти боротьбі із розповсюдженням коронавірусу, як в Україні, так і Польській Республіці.

Конституція Чеської Республіки від 16 грудня 1992 р. є специфічною у тому сенсі, що в ній відсутній, як у «традиційних» конституціях держав світу, розділ про права, свободи і обов'язки людини і громадянина. Це можна пояснити тим, що Конституція складається, фактично із двох конституційних актів: власне, Конституції, і Хартії основних прав і свобод від 9 січня 1991 р., яка $є$ складовою частиною Конституції відповідно до ст. 3 [29].

Структура зазначеної Хартії $є$ подібною до розділу про свободи, права і обов'язки людини і громадянина Конституції Польської Республіки: вона теж побудована за принципом типологізації прав і свобод, а із зазначеною Конституцією та Конституцією України ї̈ об’єднує формальна невизначеність поняття «право на здоров'я». Тим не менше, як і у двох означених конституціях, в Хартії закріплено намагання держави забезпечити це право. Так, у п. 2 ст. 7 (розділ I «Основні права і свободи людини» глави II «Права людини і основні свободи») зазначається, що «Никто не может быть подвергнут пыткам, жестокому, бесчеловечному или унижающему обращению либо наказанию» [29]. 
Так само, як і в Конституції Польської Республіки, у Хартії право на охорону здоров'я уміщено до глави IV «Економічні, соціальні і культурні права», а також чітко прописані права незахищених 3 різних причин верств населення. Зокрема, відповідно до ст. 31 «Каждый имеет право на охрану здоровья. На основе общественного страхования граждане имеют право на бесплатное медицинское обслуживание и на медицинское пособие на условиях, установленных законом», п. 1 і 2 ст. 29 «Женщины, молодежь и лица с нарушениями здоровья имеют право на повышенную охрану здоровья в процессе труда и особые условия труда»; «Молодежь и лица с нарушениями здоровья имеют право на особую защиту в трудовых отношениях и на помощь в овладении профессией» [29].

У Хартії, як і в Конституції України та Конституції Польської Республіки, зафіксовано прагнення держави забезпечити право людини і громадянина на безпечне навколишнє природне середовище. Зокрема, у п. 1 і 2 зазначається, що «Каждый имеет право на благоприятную окружающую среду»; «Каждый имеет право на своевременную и полную информацию о состоянии окружающей среды и природных ресурсов» [29].

Система охорони здоров'я у Чеській Республіці подібна до тієї, що створена у Польській Республіці, і грунтується на принципі децентралізації системи охорони здоров'я, а також обов'язкового медичного страхування (модель Бісмарка) (це відбулось у 1991 р. на основі прийнятих Закону про всезагальне медичне страхування і Закону про фонд всезагального медичного страхування). Як і y Польській Республіці, у кінці 80-х - початку 90-х років XX ст., відбувалась приватизація багатьох закладів надання медичних послуг населенню. Проте це не означає скасування безоплатної медичної допомоги, адже ст. 31 Хартії основних прав і свобод від 9 січня 1991 р. визначає, що така допомога здійснюється за рахунок коштів громадського страхування. 
Як і в Польській Республіці, фінансування медичної сфери здійснюється за принципом солідарного обов'язкового медичного страхування. Система охорони здоров'я «фінансується шляхом здійснення внесків фізичними особами та роботодавцями. На кінець 2011 р. налічується 8 фондів громадського медичного страхування (ФГМС). ФГМС є своєрідними юридичними утвореннями зі статусом громадської, неприбуткової особи, але такі організації незалежні від держави і мають власні бюджети. Ставки обов'язкових внесків на громадське медичне страхування визначені в законодавстві. Держава платить внески за всіх економічно неактивних громадян, включаючи безробітних, пенсіонерів, дітей, студентів та жінок удекретній відпустці, що разом становлять більше половини всього населення. Будь-яка особа з постійним місцем проживання у Чеській Республіці має право на медичне страхування» [30].

Організація управління системою охорони здоров'я також $\epsilon$ подібною до тієї, що створена у Польській Республіці. Так, «централізоване управління галуззю проводить міністерство охорони здоров'я, яке забезпечує єдине керування державною системою 03 та видає регулюючі нормативно-правові акти, що $є$ обов'язковими для виконання. Другим учасником процесу надання медичної допомоги у чР є фонди медичного страхування. Найбільший серед них - Фонд всезагального медичного страхування, засновником і гарантом діяльності якого $\epsilon$ держава» [31]. Нарешті, третім учасником $\epsilon$ «широка мережа закладів 03, що мають декілька форм власності: приватна (амбулаторна медична допомога самостійно практикуючі лікарі та їх об’єднання поліклініки, центри первинної допомоги); державна стаціонарна медична допомога (лікарні, університетські клініки)» [31].

Можемо констатувати, що в результаті проведених реформ у сфері охорони здоров'я, наприклад, у 2013 р. загальна тривалість життя жінок становила майже $81 \%$, а 
чоловіків - 75\% (загальна тривалість життя зросла порівняно із початком 90-х років XX ст., а кількість населення $є$ стабільним (правда, не враховуючи міграційні процеси).

Чеська Республіка також опинилась в епіцентрі розповсюдження коронавірусу. На 22 квітня кількість хворих зросла до 7136 осіб (при цьому померло 210 осіб, видужало - 2002 особи). Уперше наявність інфікованих було зафіксовано 1.03., а стрімке зростання хворих змусило уряд Чеської Республіки, на відміну від Польської Республіки і України, ввести надзвичайний стан з 12.03. строком на 30 діб і ввести карантин (умови карантину стали більш суворими із 19.03.) [32], що дозволило призупинити поширення інфекції. Крім того, введено достатньо високі штрафи за порушення умов карантину (у перерахунку на українську гривню - близько 3 мільйонів 330 тисяч гривень!!). 25.03. М03 Чеської Республіки ввело більш суворі умови карантину, а саме: «Ограничения на свободное передвижение жителей теперь дополнился дополнительным пунктом, в котором говорится, что «предлагается пребывание в общественных местах не больше двух человек, за исключением членов одного домохозяйства, предпринимательской или иной аналогичной деятельности, участия в похоронах с соблюдением дистанции не менее двух метров» [33].

Разом із тим наголосимо, що такі жорсткі заходи дали позитивний результат: 3 23.03. вперше не зафіксовано летальних випадків; тому уряд Чеської Республіки 7.04. анонсував послаблення умов карантину. Так, «з 9.04. в Чехії відкриються магазини для хобі і рукоділля, ремонт велосипедів, господарські магазини, а після Великодня, який в Чехії святкують 12 квітня, уряд обговорить можливість відкриття взуттєвих і канцелярських магазинів. Також з 14 квітня у разі поважної причини, такої, як відрядження, буде дозволений виїзд за межі Чехії» [34]. Таким чином, завдяки своєчасним заходам влади у 
Чеській Республіці (ужорсточення умов карантину, крайнє посилення штрафних санкцій за їх невиконання тощо) вдалось забезпечити не тільки необхідність збереження життя і здоров'я громадян, але й дієво протистояти розповсюдженню пандемії.

\section{Висновки}

1. Конституційне забезпечення права на здоров'я людини в Україні міститься не лише в Основному законі, але й низці конституційно-правових актів. Проведений аналіз відповідних норм засвідчує недостатню досконалість дефініцій понять i термінів, які мають віддзеркалювати зазначене право. Іншими проблемами є: відсутність сталої Концепції побудови нової національної системи охорони здоров'я України, повільність проведення медичної реформи і відходу від радянської централізованої системи управління охороною здоров'я населення та інше.

2. Конституції України, Польської Республіки і Чеської Республіки мають спільні риси щодо формулювання конституційних засад забезпечення права людини на здоров'я: принцип турботи держави за непорушність прав і свобод громадян, намагання держави у тому чи іншому вигляді сформулювати право людини на здоров'я i пов'язане 3 ним право на охорону здоров'я, єдність термінології. Разом із тим у Конституції Польської Республіки й Конституції Чеської Республіки відображене прагнення типологізувати права і свобод людини i громадянина (а у Конституції Чеської Республіки виділити права і свободи людини в окремий конституційно-правовий документ), закріпити обов'язок держави дбати про охорону здоров'я людини i громадянина. Не менш важливим $\epsilon$ і прагнення держави узяти на себе обов'язок опікуватись здоров'ям незахищених чи малозахищених з тих чи інших причин верств населення (жінки (у тому числі й вагітні), діти, 
молодь, особи похилого віку, особи з порушенням здоров'я (або особи з фізичними і розумовими вадами).

3. Досвід Польської Республіки і Чеської Республіки у сфері охорони здоров'я переконує, що варто здійснити такі кроки: а) здійснити типологізацію на конституційному рівні прав і свобод людини громадянина і виділити блок, який стосується права на здоров'я людини (або в Конституції, або через прийняття окремого акта, наприклад, Основного Закону про права і свободи людини і громадянина в Україні, попередньо провівши всеукраїнський референдум із цього питання); б) закріпити в Конституції України обов'язок держави дбати про охорону здоров'я людини і громадянина 3 відповідною термінологією; в) внести зміни до Закону України «Основи законодавства України про охорону здоров'я» у частині детального визначення понять i термінів, які відображають всі аспекти права на здоров'я людини; г) прийняти Закон України «Про децентралізацію системи охорони здоров'я в Україні», в якому чітко прописати принципові положення про обов'язкове громадське медичне страхування (уперспективі - введення спеціального «медичного податку»); разом із тим непорушною нормою має бути надання безоплатних медичних послуг у державних i комунальних (муніципальних) закладах охорони здоров'я на засадах рівності усім громадянам України, іноземцям, апатридам чи біпатридам, біженцям, особам, що просять політичного притулку, переміщеним особам тощо.

4. Досвід боротьби із поширенням інфекційної хвороби коронавірусу в Польській Республіці і Чеській Республіці може бути адаптований органами державної влади України. Зокрема, це здійснення достатньо жорстких заходів щодо запровадження умов карантину, а також посилення відповідальності за їх порушення. Приклад діяльності влади у Чеській Республіці переконує, що такі превентивні заходи, хоч вони і суттєво обмежують права громадян, $є$ суворою необхідністю. Але вони спрямовані на 
забезпечення права людини на здоров'я, а з іншого боку дозволяють державі в максимально короткі строки вийти 3 економічної кризи і повернутись до нормального життя.

\section{Список використаних джерел:}

1. Тривалість життя українців все ще найнижча в Європі - соціолог. URL: https://www.radiosvoboda.org/a/ 29256907.html

2. Проект Концепції побудови нової національної системи охорони здоров'я України від 07.08.2014 року. URL: http://oblzdrav.mk.gov.ua/index.php/gromadskarada/obgovorennya/6220-kontseptsiya-pobudovi-novojinatsionalnoji-sistemi-okhoroni-zdorov-ya-ukrajini.

3. Коронавірус в Україні: кількість зафіксованих випадків на 24 квітня. URL: https://www.rbc.ua/ukr/ news/koronavirus-ukraine-kolichestvo-zafiksirovannyh1587657177.html.

4. Шевченко А.Є., Кудін С.В. Розвиток прав людини в Україні та їх захист державою. Матеріали міжнародної науково-практичної конференції «Права людини інаціональна безпека: роль органу конституційної юрисдикцї̈» (м. Київ, 27 червня 2019 р.). Київ : КНУ імені Тараса Шевченка. С. 346-353.

5. Anatolii Shevchenko, Olena Kalhanova, Serhii Kudin \& Olena Kravchenko. Guarantees of realization of the rights and freedoms of the person in the national legal system: teaching technique. Asia Life Sciences. The Asian International Journal of Life Sciences. Supplement 21(2) 2019. S. 535-548.

6. Конституція України від 28 червня 1996 року. URL: https://zakon.rada.gov.ua/laws/show/254к/96-вр/.

7. Руснак Л.М. Адміністративно-правове забезпечення права на охорону здоров'я в Україні : дис. ... канд. юрид. наук. Київ, 2016. 207 с.

8. Закон України «Основи законодавства України про охорону здоров'я» від 19.11 .1992 р. в редакції від 29.12.2019 p. URL: https://zakon.rada.gov.ua/laws/show/ 2801-12. 
9. Закон України «Про забезпечення санітарного та епідеміологічного благополуччя населення» від 24.02.1994 p. в редакції від 04.10 .2018 p. URL: https://zakon.rada.gov.ua/laws/show/4004-12.

10. Права людини в сфері охорони здоров'я та форми їх захисту. URL: http://korosten-rada.gov.ua/sotsialniyrozvitok/ohorona-zdorovya/tsentralna-miska-likarnya/pravalyudini-v-sferi-ohoroni-zdorovya/.

11. Скалецька 3.С. Співвідношення права на охорону здоров'я та права на медичну допомогу. Наукові записки НаУКМА. Юридичні науки. 2009. Том. 90. С. 91-93.

12. Конституційне закріплення права на охорону здоров'я. Порівняльний аналіз конституційної практики. URL: http://bkb-law.com.ua/index.php?option.

13. Швець Ю. Зміст конституційного права особи на охорону здоров'я. Підприємнищтво, господарство і право. 2017. № 8. С. 135-138.

14. Лещенко В.В., Радиш Я.Ф. Права людини на життя та охорону здоров'я - методологічна основа державного управління здоровоохоронною сферою: вступ до проблеми. Державне управління: теорія та практика. 2014. № 1. C. 104-113.

15. Назарко Ю.В. Гарантії реалізації права на охорону здоров'я в Україні та країнах Європейського Союзу. Юридичний часопис Національної академії внутрішніх справ. 2018. № 1(15). С. 405-418.

16. Роханський А. Права людини в галузі охорони здоров'я. URL: https://helsinki.org.ua/prava-lyudyny-v-haluziohorony-zdorov-ya-a-rohanskyj/.

17. Шамич О.М. Співвідношення права людини на охорону здоров'я і права на життя в Україні. Актуальні проблеми навчання та виховання людей з особливими потребами. 2015. № 12. С. 219-233.

18. Шекера О.Г. Конституційні основи охорони здоров'я громадян в Україні. Збірник наукових пращь співробітників НМАПО імені П.Л. Шупика. 2013. № 22(4). С. 526-533. 
19. Національна стратегія побудови нової системи охорони здоров'я в Україні на період 2015-2025 років, розроблена Стратегічною дорадчою групою 3 питань реформування системи охорони здоров'я в Україні. URL: https://healthsag.org.ua/wpcontent/uploads/2014/11/Proekt-Strategiyi-reformi_0Z.pdf.

20. Постанова Верховної Ради України «Про Рекомендації парламентських слухань на тему: «Про реформу охорони здоров'я в Україні» від 21.04.2016 року. URL: https://zakon.rada.gov.ua/laws/show/1338-19.

21. Концепція побудови нової національної системи охорони здоров'я України, анонсована Незалежною експертною платформою «ПРО S VITA» 08.11.2017 року. URL: https://www.ukrinform.ua/rubric-presshall/2335458nova-nacionalna-sistema-ohoroni-zdorova-ukraini-koncepciavid-pro-s-vita.html.

22. Закон України «Про внесення змін до деяких законодавчих актів України, спрямованих на запобігання виникненню і поширенню коронавірусної хвороби (COVID19)» від 17.03.2020 р. у редакції від 18.04.2020 p. URL: https://zakon.rada.gov.ua/laws.

23. Постанова Кабінету Міністрів України «Про запобігання поширенню на території України коронавірусу COVID-19» від 11.03.2020 p. URL: https://www.kmu.gov.ua/ npas/pro-zapobigannya-poshim110320rennyu-na-teritoriyiukrayini-koronavirusu-covid-19.

24. Конституція Польської Республіки (з передмовою Володимира Шаповала). Київ : Москаленко О.М., 2018. 84 с.

25. Чмель 0., Пустовойт Д., Шмігель А. Аналіз системи охорони здоров'я в Польщі. Сучасні економічні дослідження. 2018. № 1. Вип. 1. С. 13-20.

26. Даневич Б. Медицинская реформа: полезный опыт Польши для Украины (17 октября 2017 г.). URL: https://www.pravda.com.ua/rus/columns/2017/10/17/7158 $694 /$.

27. Президент Польщі підписав спецзакон про боротьбу із коронавірусом. URL: https://nv.ua/ukr/world/countries/ 
koronavirus-u-polshchi-prezident-pidpisav-speczakon-proborotbu-z-covid-19-50074399.html.

28. Польша ввела состояние эпидемии из-за коронавируса. URL: https://zik.ua/ru/news/world/polsha_ vvela_sostoyanie_epidemii_cherez_koronavirus_962862.

29. Конституция Чехии (Чешской Республики) от 16 декабря 1992 года. URL: https://czholding.ru/aboutcz/konstitucija-chehii/.

30. Достал 0. Міжнародний досвід реформування первинної медичної допомоги у Чехії. URL: https://www.umj.com.ua/article/22698/mizhnarodnij-dosvidreformuvannya-pervinnoi-medichnoi-dopomogi-chexiya.

31. Бодян М.В. Система охорони здоров'я в Чеській Республіці. URL: https:// www.mif-ua.com/archive/article/ 38604.

32. Распространение COVID-19 в Чехии. URL: https://ru.wikipedia.org/wiki/.

33. Чехия ужесточила карантинные меры. URL: https://www.rbc.ua/rus/news/chehiya-uzhestochilakarantinnye-mery-1585152098.html.

34. у Чехії та Данії почали послаблювати карантин. URL: https://espreso.tv/news/2020/04/07/u_chekhiyi_ta_ daniyi_pochaly_poslablyuvaty_karantyn. 


\section{«ПРАВА ЛЮДИНИ В УКРАЇНІ \\ ТА У ЗАРУБІЖНИХ КРАЇНАХ: \\ ПРОБЛЕМИ ТЕОРІЇ ТА НОРМАТИВНО-ПРАВОВОЇ \\ РЕГЛАМЕНТАЦЇ̈»}

\section{Колективна монографія}

Батанов О. В., Васильченко О. П., Матат А. В., Волощук О. Т., Головашук А. П., Гулієв А. Д., Денисов В. Н., Фалалєєва Л. Г., Заморська Л. І., Гураленко Н. А., Заяџь Н. В., Козакевич О. М., Крестовська Н. М., Матвєєва Л. Г., Лотюк О. С., Митник О. В., Любченко М. І., Буряковська К. О., Міхальов В. О., Полішук Н. Р., Тімофєєва Л. Ю., Шевченко А. Є., Кудін С. В.

Підписано до друку 14.05.2020. Формат 60x84/16.

Папір офсетний. Гарнітура Cambria. Цифровий друк.

Ум.-друк. арк. 22,79. Наклад 100. Замовлення № 0720м-161. Ціна договірна. Віддруковано з готового оригінал-макета.

Надруковано: ТОВ "ЛІГА-ПРЕС" Свідоцтво суб'єкта видавничої справи ДК № 6423 від 04.10.2018 р. Україна, м. Львів, 79012, вул. Кастелівка, 9 Польща, м. Торунь, 87-100, вул. Лубіцка, 44 Тел. +38 (050) 7581436 